
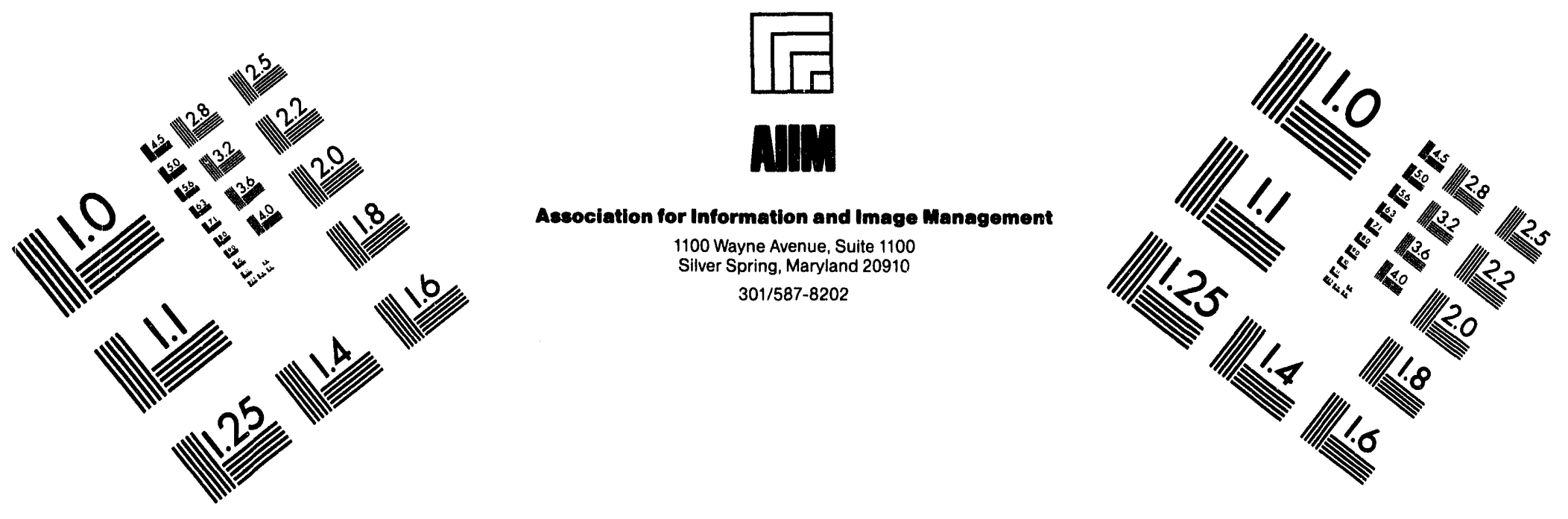

\title{
Centimeter
}

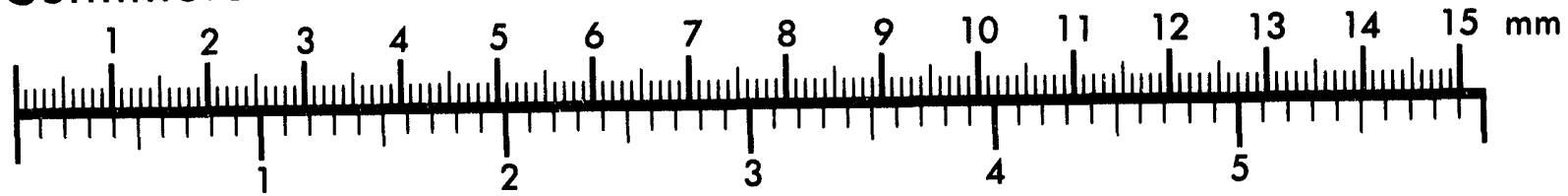
Inches
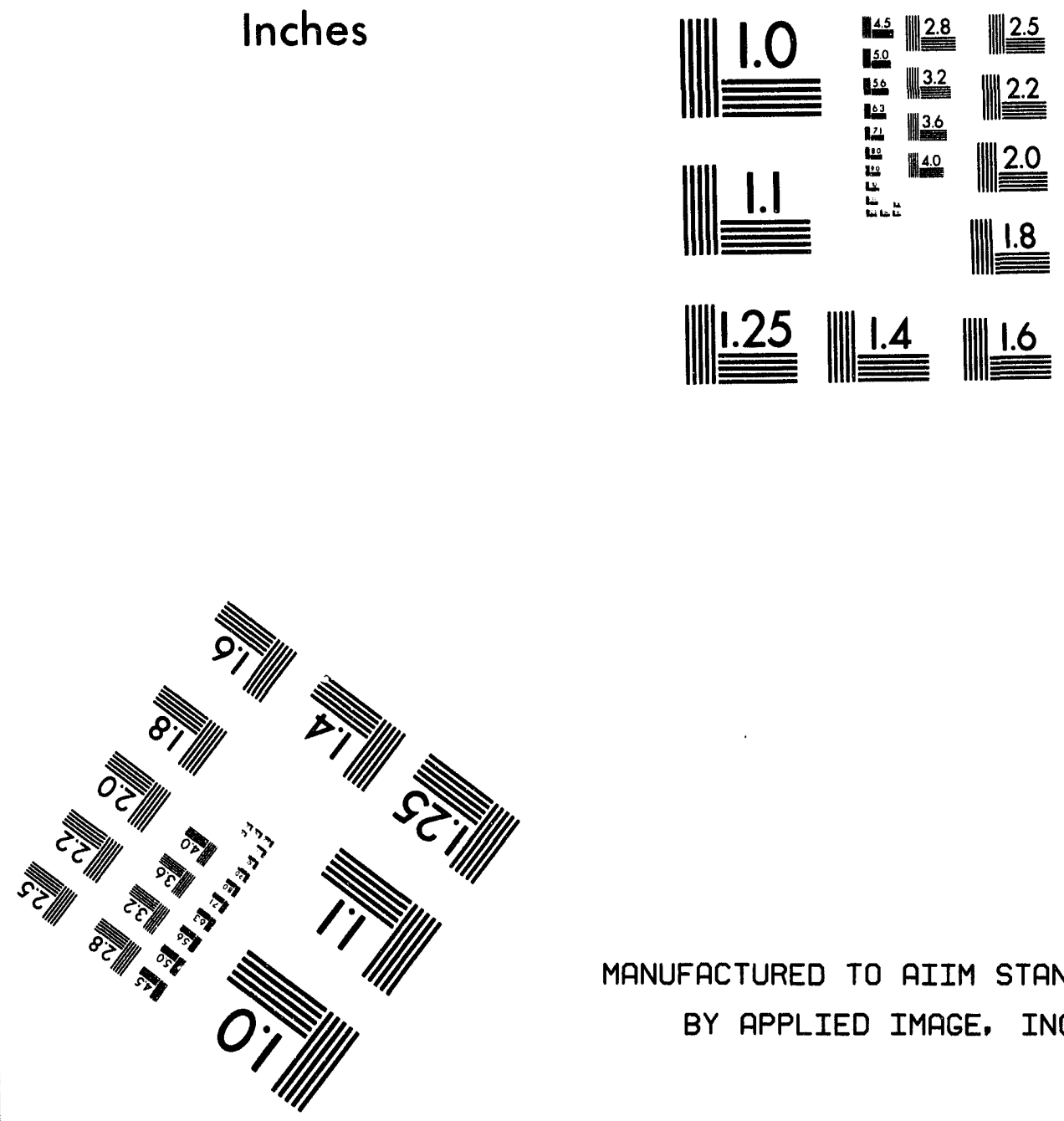

MANUFACTURED TO AIIM STANDARDS

BY APPLIED IMAGE, INC.

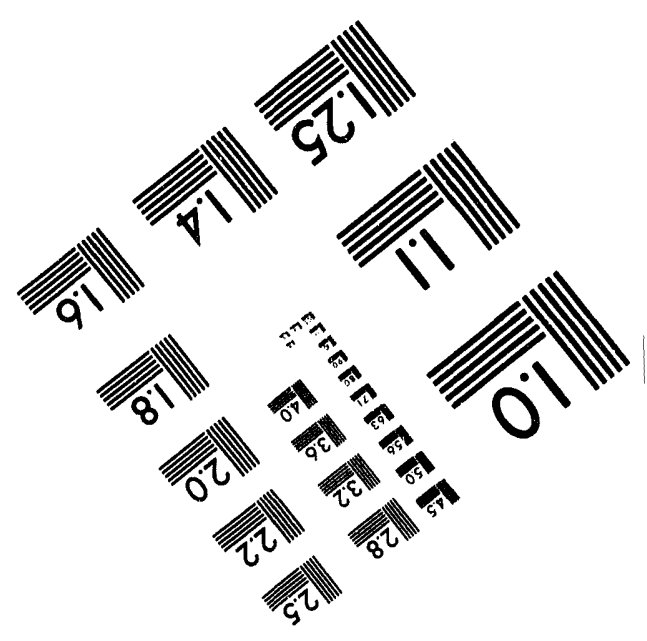



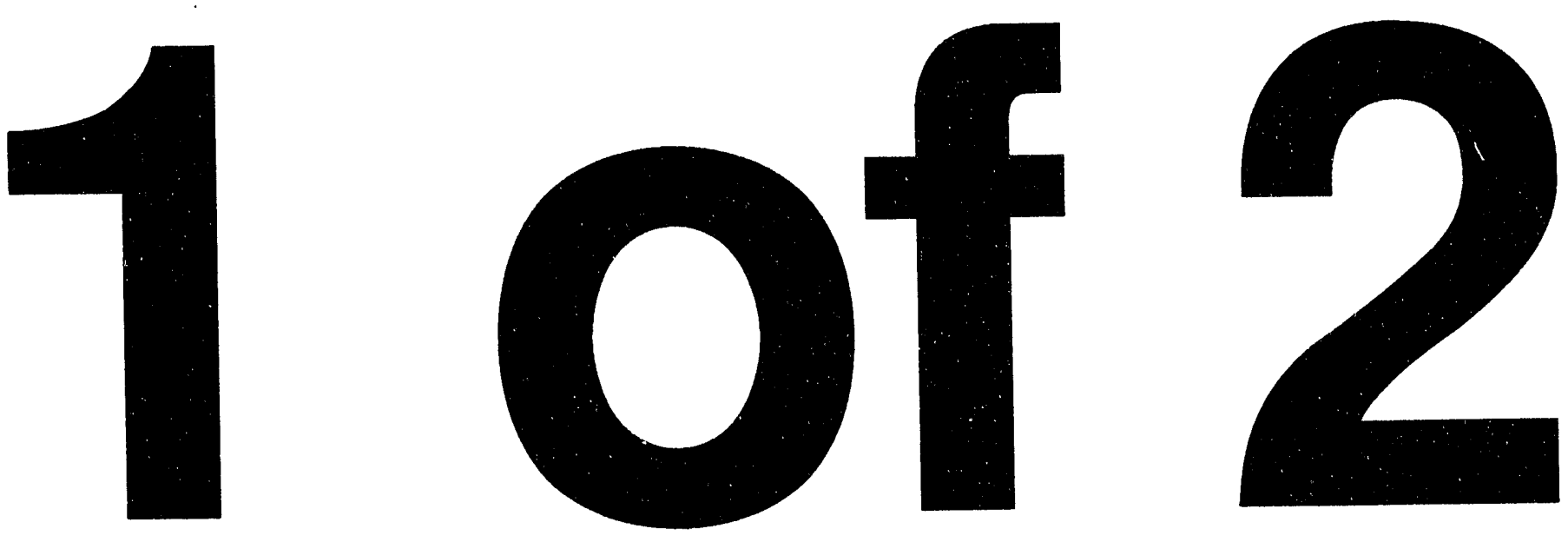


\section{Alternatives to Traditional Transportation Fuels: An Overview}

\section{June 1994}

\section{Energy Information Administration}

Office of Coal, Nuclear, Electric and Alternate Fuels

U.S. Department of Energy

Washington, DC 20585

This report was prepared by the Energy Information Administration, the independent statistical and analytical agency within the Department of Energy. The information contained herein should not be construed as advocating or reflecting any policy position of the Department of Energy or of any other organization. 


\section{Contacts}

This report was prepared by the Energy Information Administration (EIA), Office of Coal, Nuclear, Electric and Alternate Fuels (CNEAF). General information about data in this document may be obtained from the National Energy Information Center (202/586-8800). Further information about the report may be referred to John Geidl (202/254-5570), Director of the CNEAF; Howard Walton (202/254-5500), Director of the Survey Management Division; Fred Mayes (202/254-5300), Chief of the Renewable and Financial Data Systems and Outreach Branch, Dean Fennell (202/254-5660); James Disbrow (202/254-5558); Janet Gordon (202/254-5472); or Robert Lowe (202/254-5557).
The Office of Coal, Nuclear, Electric and Alternate Fuels would like to thank the following people for their contributions to this report: Jeff Alson and Katy Gold, Environmental Protection Agency, Office of Mobile Sources; Jeff Clark, Environmental Protection Agency, Office of Air Quality Standards; Robert Jarcho, Department of Interior; James Link, Department of Transportation; Paul McArdle, Barry McNutt, and David Rodgers, Department of Energy; Commander Marc McConahy, Department of Navy; Denise Patterson, Department of Agriculture; and William Rivers, General Services Administration. 


\title{
Listing of Commonly Used Acronyms
}

\author{
AFV ......... Alternative Fuel Vehicle \\ AMFA . . . . . . A Alternative Motor Fuels Act of 1988 \\ ATF ......... Alternative Transportation Fuel \\ CAA ......... Clean Air Act of 1963 \\ CAAA ...... Clean Air Act Amendments of 1990 \\ CNG .......... Compressed Natural Gas \\ CO .......... Carbon Monoxide \\ $\mathrm{CO}_{2} \ldots \ldots \ldots$ Carbon Dioxide \\ DOE ........ U.S. Department of Energy \\ EPA ........ U.S. Environmental Protection Agency \\ E-10 . . . . . 10 percent ethanol/90 percent gasoline \\ E-85 . . . . . . 85 percent ethanol/15 percent gasoline \\ E-95, E-100 ... Neat ethanol with a 5 percent denaturing agent \\ EPACT . . . . . E Energy Policy Act of 1992 \\ ETBE ........ Ethyl Tertiary-Butyl Ether \\ FHWA $\ldots \ldots \ldots$ Federal Highway Administration \\ GSA ......... General Services Administration \\ ILEV . . . . . . . Inherently Low-Emission Vehicle \\ IM .......... Inspection/Maintenance \\ MTBE ........ Methyl Tertiary-Butyl Ether \\ NAAQS ....... National Ambient Air Quality Standards \\ NO .......... Nitrous Oxide \\ $\mathrm{NO}_{2} \ldots \ldots \ldots$ Nitrogen Dioxides \\ $\mathrm{NO}_{\mathrm{x}} \ldots \ldots \ldots$ Nitrogen Oxides (includes $\mathrm{NO}$ and $\mathrm{NO}_{2}$ ) \\ LEV ......... Low-Emission Vehicle \\ LNG ......... Liquefied Natural Gas \\ LPG ......... Liquefied Petroleum Gas \\ M-85 . . . . . . 85 percent methanol 15 percent gasoline \\ M-100 . . . . . Neat Methanol \\ NMHC ....... Nonmethane Hydrocarbon \\ NMOG ....... Nonmethane Organic Gas \\ PM .......... Particulate Matter \\ RFG ........ Reformulated Gasoline \\ RVP $\ldots \ldots \ldots$ Reid Vapor Pressure \\ $\mathrm{SO}_{\mathrm{x}} \ldots \ldots \ldots$. . . Sulfur Oxides \\ ULEV . . . . . . . Ultra-Low-Emission Vehicle \\ VOC . . . . . . . . Volatile Organic Compound \\ VMT . . . . . . . . Vehicle Miles Traveled \\ ZEV ......... Zero-Emission Vehicle
}




\section{Contents}

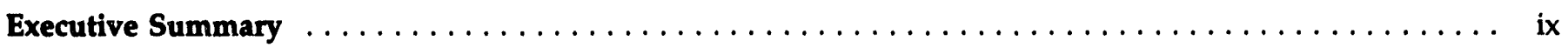

\section{Section 1: Alternative Fuels Data}

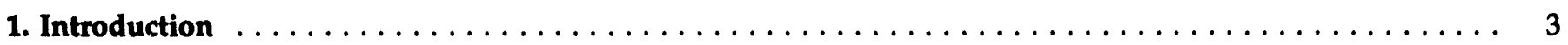

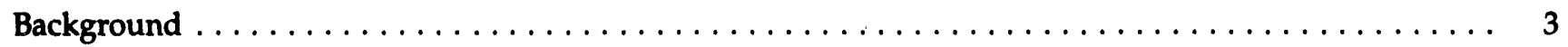

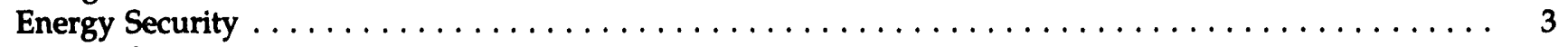

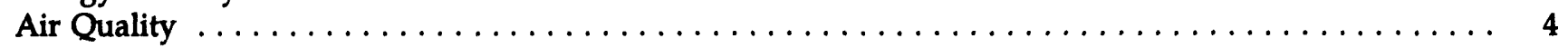

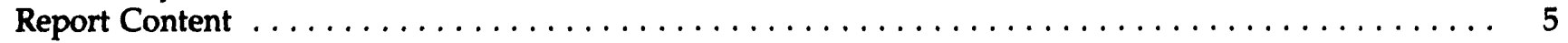

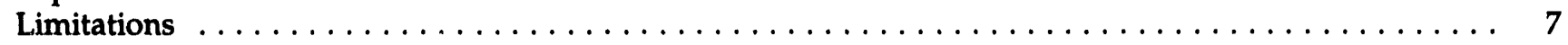

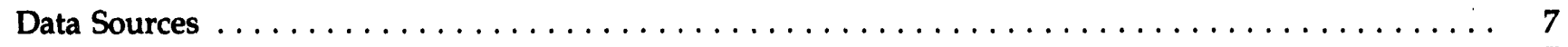

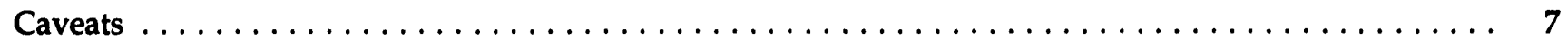

2. Status of Alternative Fueled Vehicles $\ldots \ldots \ldots \ldots \ldots \ldots \ldots \ldots \ldots \ldots \ldots \ldots \ldots \ldots \ldots \ldots$

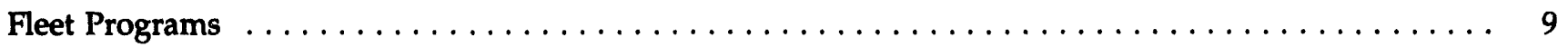

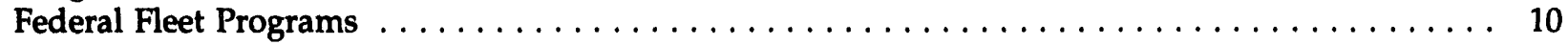

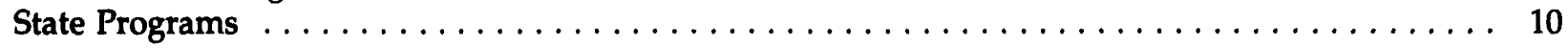

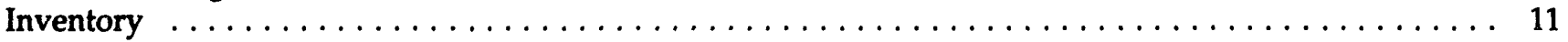

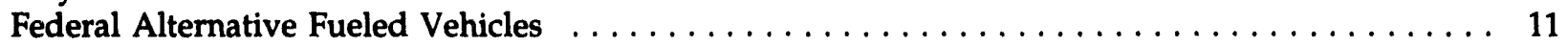

Non-Federal Alternative Fueled Vehicles $\ldots \ldots \ldots \ldots \ldots \ldots \ldots \ldots \ldots \ldots \ldots \ldots \ldots \ldots$

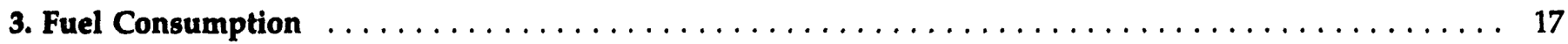

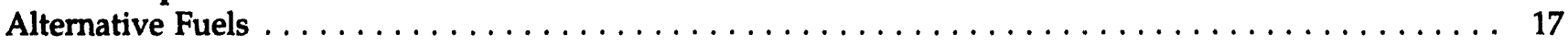

Methanol Consumption $\ldots \ldots \ldots \ldots \ldots \ldots \ldots \ldots \ldots \ldots \ldots \ldots \ldots \ldots \ldots \ldots \ldots \ldots \ldots$

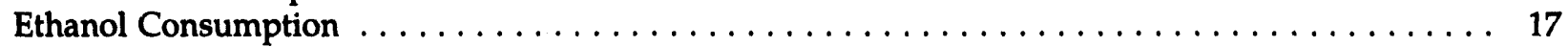

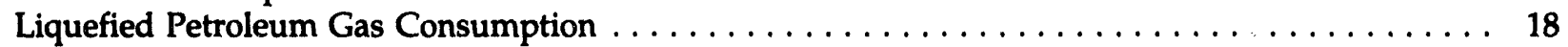

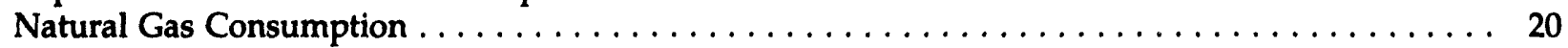

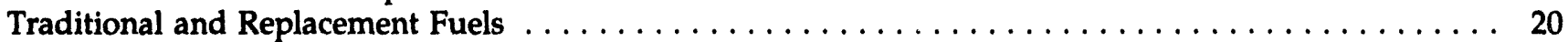

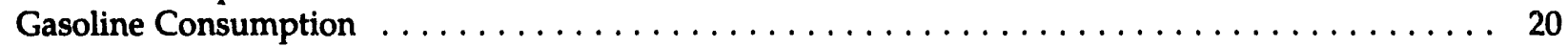

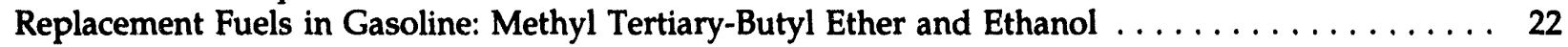

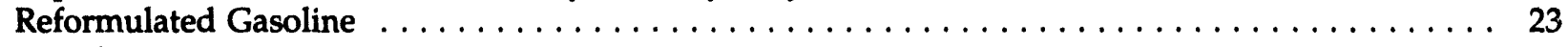

Diesel Consumption $\ldots \ldots \ldots \ldots \ldots \ldots \ldots \ldots \ldots \ldots \ldots \ldots \ldots \ldots \ldots \ldots \ldots \ldots \ldots$

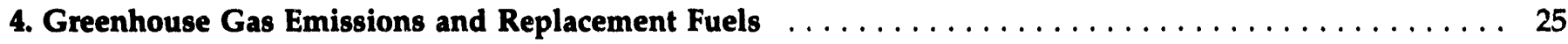

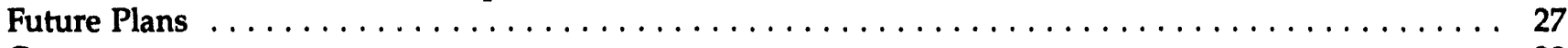

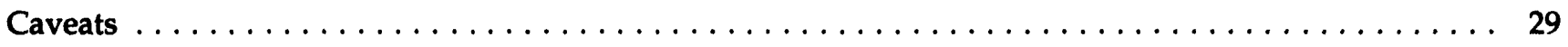

\section{Section 2: Technology}

5. Legislation Affecting Use of Alternative Fuels $\ldots \ldots \ldots \ldots \ldots \ldots \ldots \ldots \ldots \ldots \ldots \ldots \ldots \ldots \ldots$

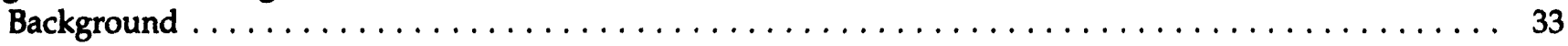

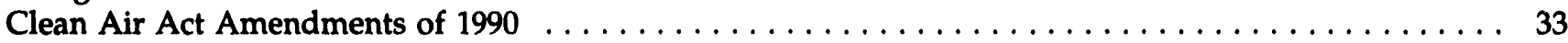

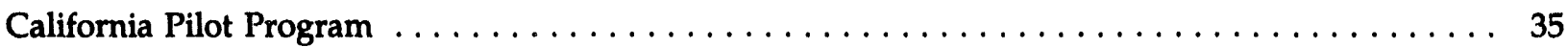

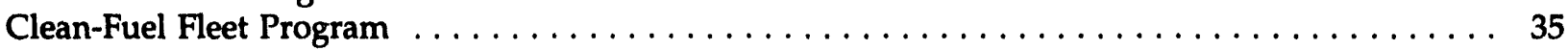

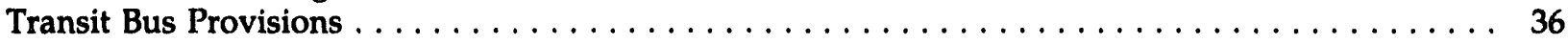

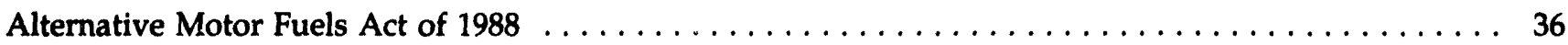

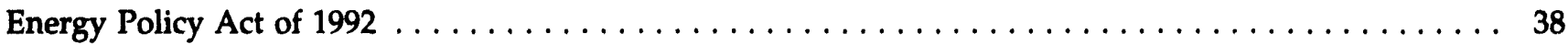

Executive Order 12844: Federal Use of Alternative Fueled Vehicles $\ldots \ldots \ldots \ldots \ldots \ldots \ldots \ldots \ldots \ldots$ 
Role of EPA in Regulation of Emissions $\ldots \ldots \ldots \ldots \ldots \ldots \ldots \ldots \ldots \ldots \ldots \ldots \ldots \ldots \ldots \ldots$

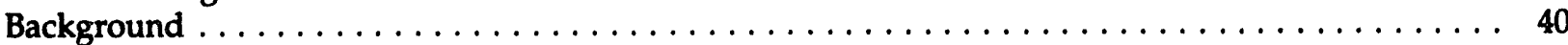

Mobile Source Emissions $\ldots \ldots \ldots \ldots \ldots \ldots \ldots \ldots \ldots \ldots \ldots \ldots \ldots \ldots \ldots \ldots \ldots \ldots$

Vehicular Emissions Standards $\ldots \ldots \ldots \ldots \ldots \ldots \ldots \ldots \ldots \ldots \ldots \ldots \ldots \ldots \ldots \ldots \ldots \ldots$

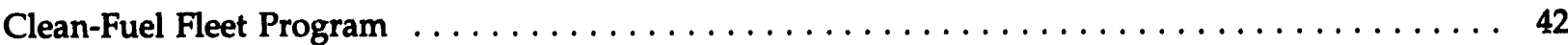

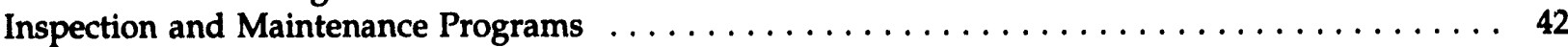

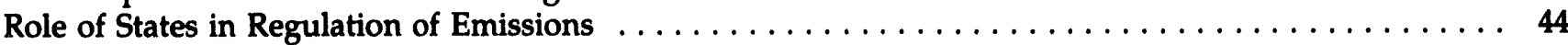

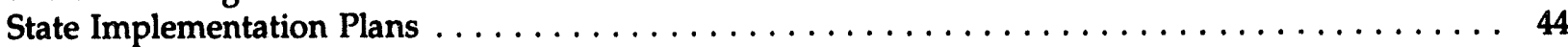

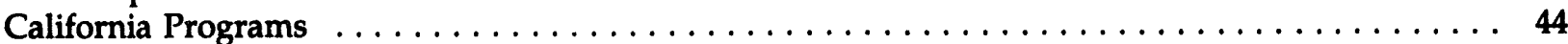

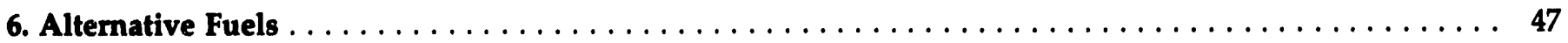

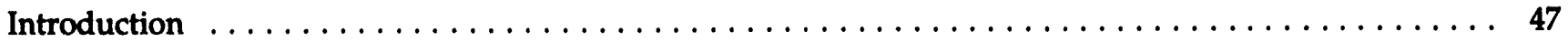

Hydrogen $\ldots \ldots \ldots \ldots \ldots \ldots \ldots \ldots \ldots \ldots \ldots \ldots \ldots \ldots \ldots \ldots \ldots \ldots \ldots \ldots$

Compressed Natural Gas and Liquefied Natural Gas $\ldots \ldots \ldots \ldots \ldots \ldots \ldots \ldots \ldots \ldots$

Liquefied Petroleum Gas $\ldots \ldots \ldots \ldots \ldots \ldots \ldots \ldots \ldots \ldots \ldots \ldots \ldots \ldots \ldots$

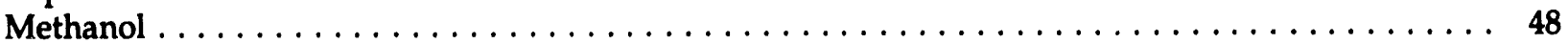

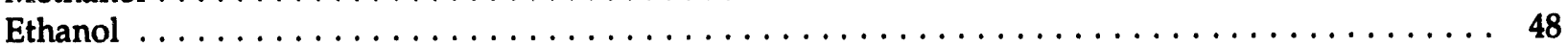

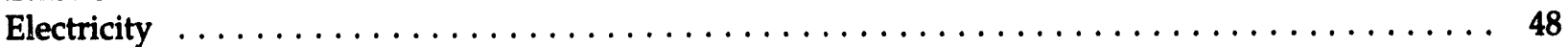

Physical and Chemical Characteristics $\ldots \ldots \ldots \ldots \ldots \ldots \ldots \ldots \ldots \ldots \ldots \ldots \ldots \ldots \ldots \ldots$

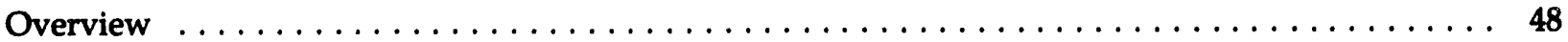

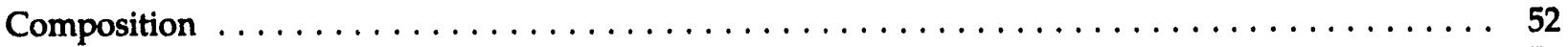

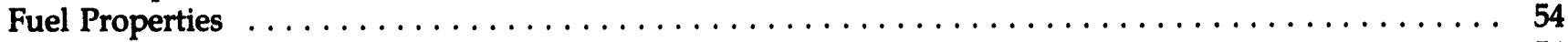

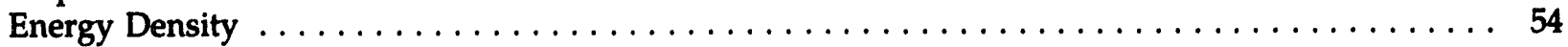

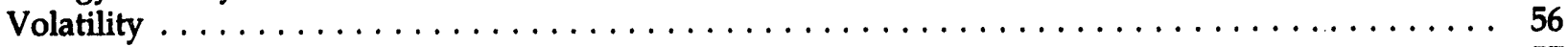

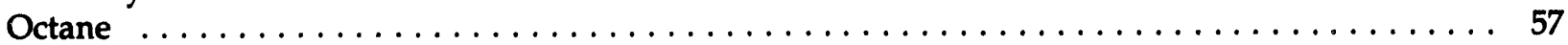

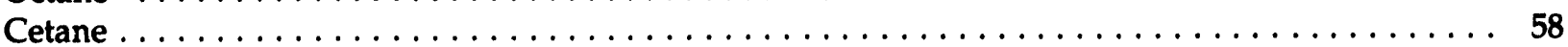

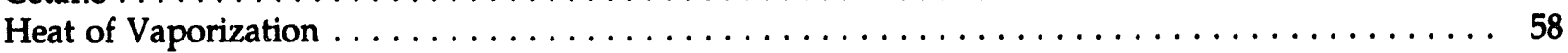

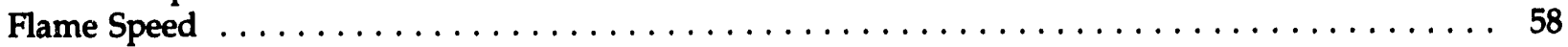

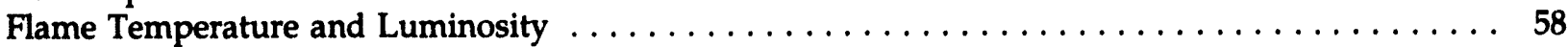

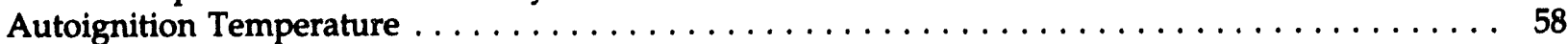

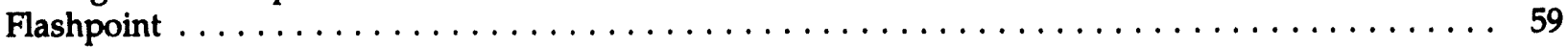

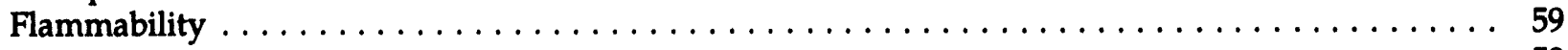

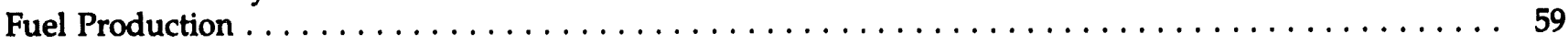

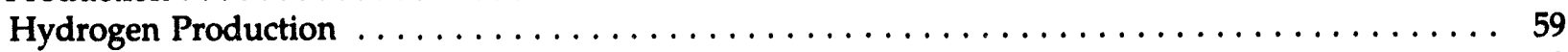

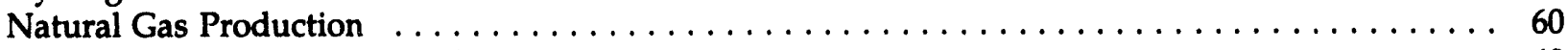

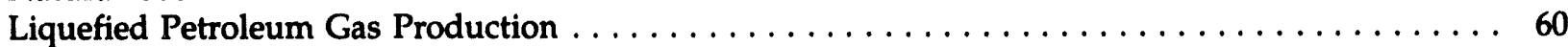

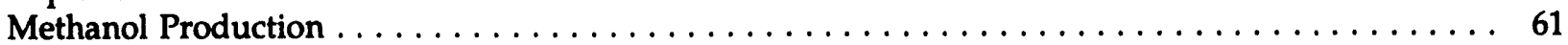

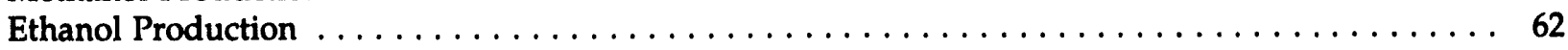

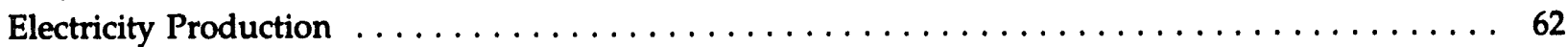

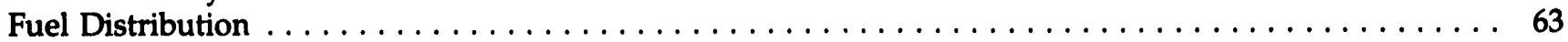

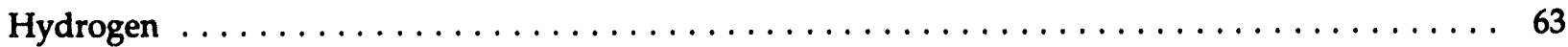

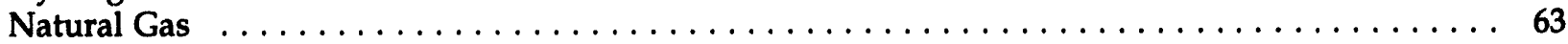

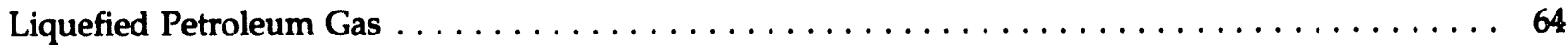

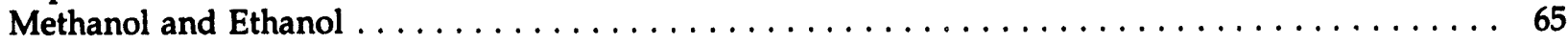

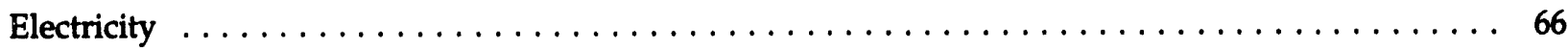

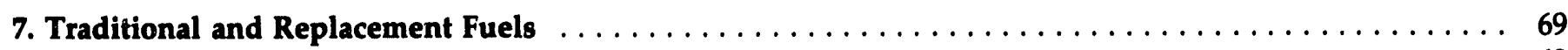

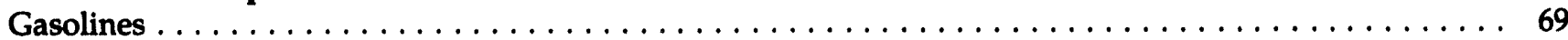

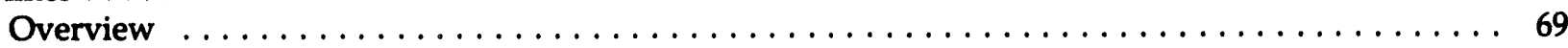

Physical and Chemical Characteristics of Gasolines $\ldots \ldots \ldots \ldots \ldots \ldots \ldots \ldots \ldots \ldots \ldots \ldots$

Fuel Properties of Gasolines $\ldots \ldots \ldots \ldots \ldots \ldots \ldots \ldots \ldots \ldots \ldots \ldots \ldots \ldots \ldots \ldots \ldots$

Conventional, Oxygenated, and Reformulated Gasoline Production $\ldots \ldots \ldots \ldots \ldots \ldots \ldots \ldots$

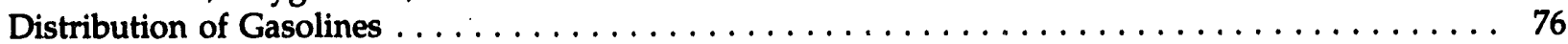




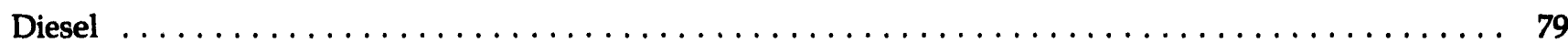

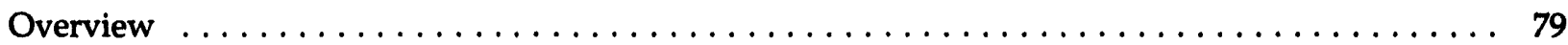

Physical and Chemical Properties of Diesel $\ldots \ldots \ldots \ldots \ldots \ldots \ldots \ldots \ldots \ldots \ldots \ldots \ldots \ldots$

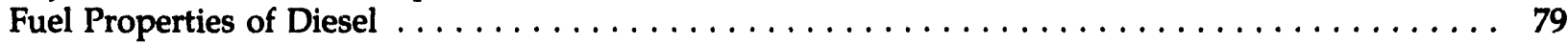

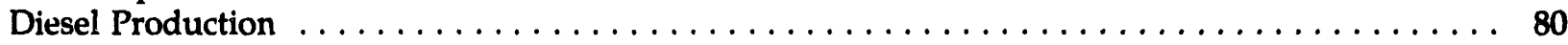

Diesel Distribution $\ldots \ldots \ldots \ldots \ldots \ldots \ldots \ldots \ldots \ldots \ldots \ldots \ldots \ldots \ldots \ldots \ldots \ldots$

8. Characteristics of Alternative Fueled Vehicles $\ldots \ldots \ldots \ldots \ldots \ldots \ldots \ldots \ldots \ldots \ldots \ldots \ldots \ldots \ldots$

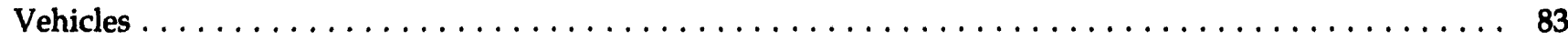

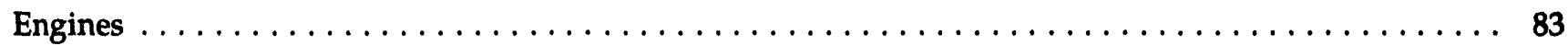

Vehicle/Engine Systems $\ldots \ldots \ldots \ldots \ldots \ldots \ldots \ldots \ldots \ldots \ldots \ldots \ldots \ldots \ldots \ldots \ldots \ldots \ldots \ldots$

Alcohol-Fueled Vehicles $\ldots \ldots \ldots \ldots \ldots \ldots \ldots \ldots \ldots \ldots \ldots \ldots \ldots \ldots \ldots \ldots \ldots$

Liquefied Petroleum Gas Vehicles $\ldots \ldots \ldots \ldots \ldots \ldots \ldots \ldots \ldots \ldots \ldots \ldots \ldots \ldots \ldots$

Natural Gas Vehicles $\ldots \ldots \ldots \ldots \ldots \ldots \ldots \ldots \ldots \ldots \ldots \ldots \ldots \ldots \ldots \ldots \ldots \ldots$

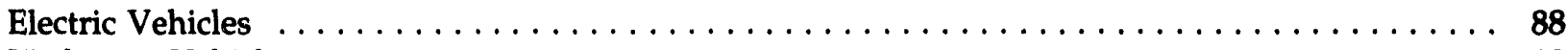

Hydrogen Vehicles $\ldots \ldots \ldots \ldots \ldots \ldots \ldots \ldots \ldots \ldots \ldots \ldots \ldots \ldots \ldots \ldots \ldots \ldots$

9. Emerging Fuel Resources $\ldots \ldots \ldots \ldots \ldots \ldots \ldots \ldots \ldots \ldots \ldots \ldots \ldots \ldots \ldots \ldots \ldots \ldots \ldots \ldots \ldots$

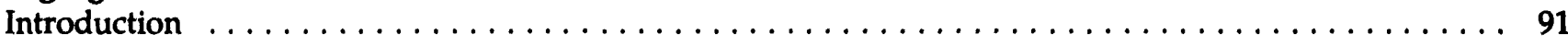

Biodiesel from Vegetable Oils $\ldots \ldots \ldots \ldots \ldots \ldots \ldots \ldots \ldots \ldots \ldots \ldots \ldots \ldots \ldots \ldots \ldots \ldots \ldots$

Coal-Derived Transportation Fuels $\ldots \ldots \ldots \ldots \ldots \ldots \ldots \ldots \ldots \ldots \ldots \ldots \ldots \ldots \ldots \ldots \ldots \ldots$

10. Greenhouse Gas and Harmful Emission Formation $\ldots \ldots \ldots \ldots \ldots \ldots \ldots \ldots \ldots \ldots \ldots \ldots \ldots$

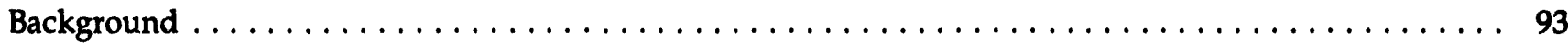

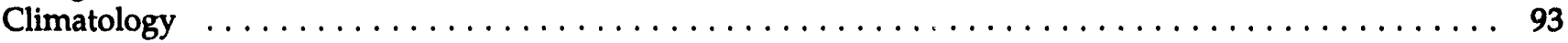

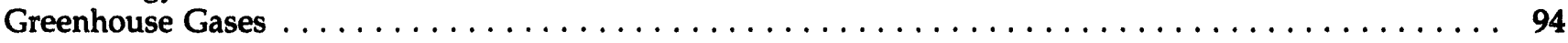

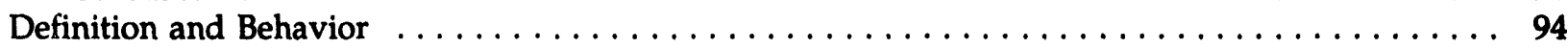

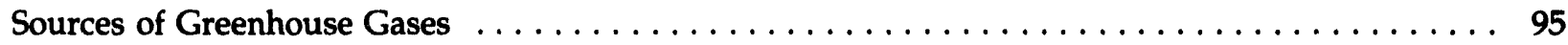

Determining the Background Level of a Greenhouse Gas $\ldots \ldots \ldots \ldots \ldots \ldots \ldots \ldots \ldots$

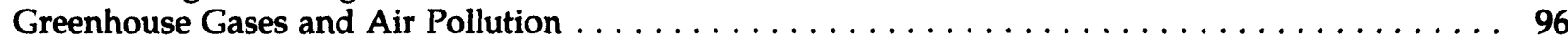

Other Air Pollutants from Transportation Fuels $\ldots \ldots \ldots \ldots \ldots \ldots \ldots \ldots \ldots \ldots \ldots \ldots \ldots \ldots \ldots 1$

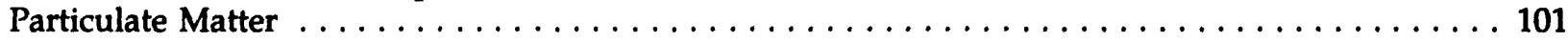

Appendices

A. State Government Initiatives $\ldots \ldots \ldots \ldots \ldots \ldots \ldots \ldots \ldots \ldots \ldots \ldots \ldots \ldots \ldots \ldots \ldots \ldots \ldots$

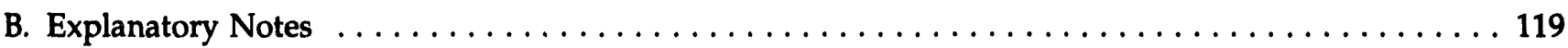

C. Listing of Sources for Information on Alternative Fueled Vehicles $\ldots \ldots \ldots \ldots \ldots \ldots \ldots \ldots \ldots \ldots$

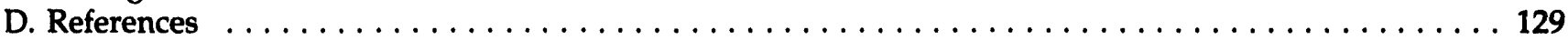

E. Relationship of Fuel Chemistry to Engine Performance $\ldots \ldots \ldots \ldots \ldots \ldots \ldots \ldots \ldots \ldots \ldots \ldots 131$

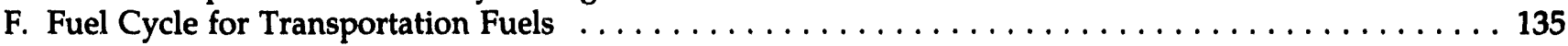

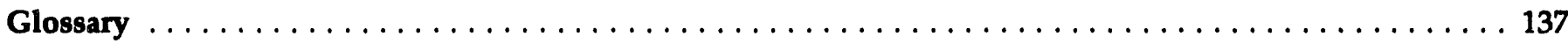


1. Topic Index for Alternative and Replacement Fuels $\ldots \ldots \ldots \ldots \ldots \ldots \ldots \ldots \ldots \ldots \ldots \ldots$

2. Estimated Number of Alternative Fueled Vehicles by Ownership Class, $1992 \ldots \ldots \ldots \ldots \ldots \ldots$. . . . 11

3. Actual and Estimated Numbers of Alternative Fueled Vehicles in the Federal Fleet, 1992-1994 . . . . . . 12

4. Estimated Number of Non-Federal Alternative Fueled Vehicles by Weight Class, 1992 and 1994 . . . . 13

5. Estimated Number of Non-Federal Alternative Fueled Vehicles by Ownership and Weight Class,

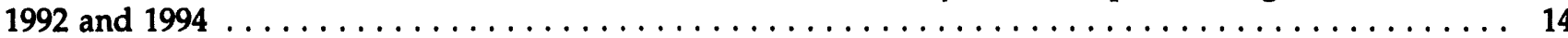

6. Summary of Fuel Consumption, $1992 \ldots \ldots \ldots \ldots \ldots \ldots \ldots \ldots \ldots \ldots \ldots \ldots \ldots \ldots \ldots \ldots$

7. Estimated Methanol Consumption in North America, 1991 and $1992 \ldots \ldots \ldots \ldots \ldots \ldots \ldots \ldots \ldots$

8. M-85 Consumption for Highway Use in California, 1992 and $1993 \ldots \ldots \ldots \ldots \ldots \ldots \ldots \ldots$

9. Geographic Distribution of U.S. Ethanol Consumption in Gasohol Sales, Selected Years, 1980-1992 . . . 19

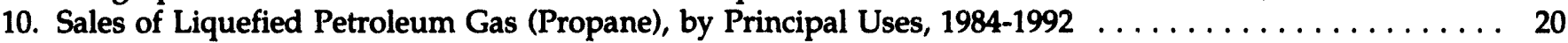

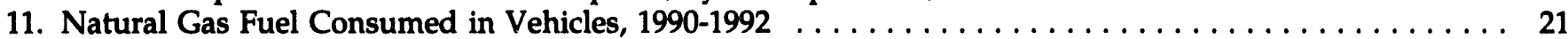

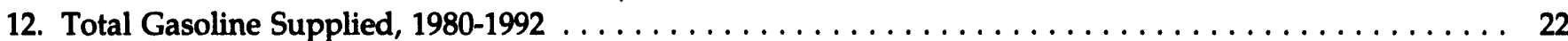

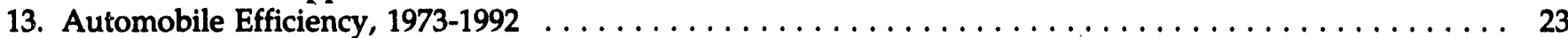

14. Replacement Fuel Use in Gasoline, $1992 \ldots \ldots \ldots \ldots \ldots \ldots \ldots \ldots \ldots \ldots \ldots \ldots \ldots \ldots \ldots \ldots$

15. Percentage of Total Gasoline Sales Potentially Affected by Carbon Monoxide or Ozone Restrictions . . . 24

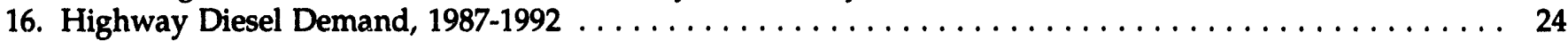

17. Emissions of Selected Greenhouse Gases from Mobile Sources, 1985 and $1991 \ldots \ldots \ldots \ldots \ldots \ldots$

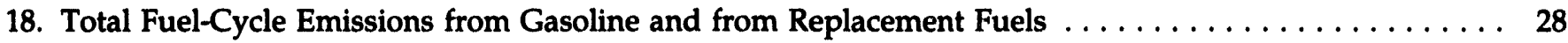

19. Carbon Monoxide Exceedances in Areas With Oxygenated Fuel Programs (Except California), 1987-1993

20. Alternative Fueled Vehicle Targets for the Federal Fleet $\ldots \ldots \ldots \ldots \ldots \ldots \ldots \ldots \ldots \ldots \ldots \ldots \ldots$

21. Emissions Standards for Light-Duty Vehicles $\ldots \ldots \ldots \ldots \ldots \ldots \ldots \ldots \ldots \ldots \ldots \ldots \ldots \ldots \ldots \ldots$

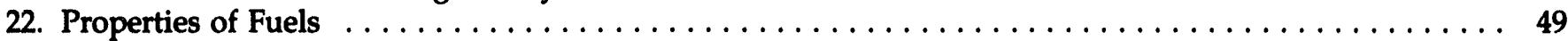

23. Typical Volumetric and Mass Base Composition of Natural Gas . . . . . . . . . . . . . . . 52

24. Weighted National Statistics for Natural Gas in Ten Major Urban Areas of the United States With and Without Propane/Air (P/A) Peakshaving $\ldots \ldots \ldots \ldots \ldots \ldots \ldots \ldots \ldots \ldots \ldots \ldots$

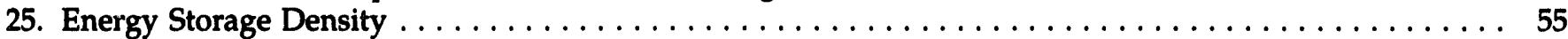

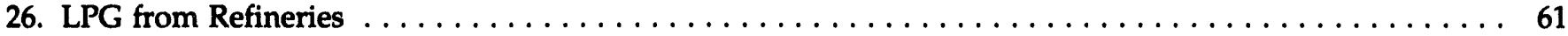

27. Selected Properties of Methyl Tertiary-Butyl Ether (MTBE) and Ethanol $\ldots \ldots \ldots \ldots \ldots \ldots \ldots \ldots \ldots$

28. Examples of Component Streams for Gasoline $\ldots \ldots \ldots \ldots \ldots \ldots \ldots \ldots \ldots \ldots \ldots \ldots \ldots \ldots \ldots 74$

29. Change in Composition of Feedstock in Reforming $\ldots \ldots \ldots \ldots \ldots \ldots \ldots \ldots \ldots \ldots \ldots \ldots \ldots, 74$

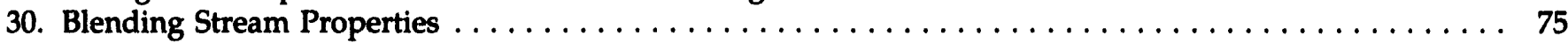

31. Illustrative Cost to Transport Gasoline from the U.S. Gulf Coast to a Boston Service Station . . . . . . 77

32. U.S. Gasoline Shares by Retail Category, $1988-1992 \ldots \ldots \ldots \ldots \ldots \ldots \ldots \ldots \ldots \ldots \ldots \ldots \ldots \ldots \ldots$

33. Estimated World Vegetable Oil Production and Yields, $1990 \ldots \ldots \ldots \ldots \ldots \ldots \ldots \ldots \ldots \ldots \ldots \ldots . \ldots 1$

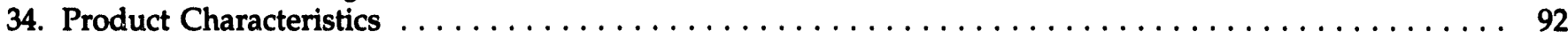

35. Atmospheric Concentrations of Selected Greenhouse Gases, $1990 \ldots \ldots \ldots \ldots \ldots \ldots \ldots \ldots$. . . . . . 94

36. Emissions of Primary Air Pollutants by Highway Vehicles in the United States, 1940-1990

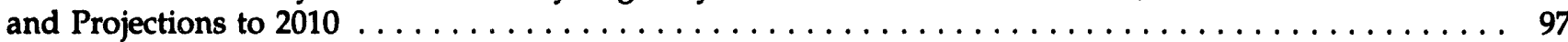

37. Emissions of Nitrogen Oxides and Nonmethane Volatile Organic Compounds by Source, 1991 . . . . . 98

38. Metropolitan Statistical Areas That Exceeded NAAQS Standards for Carbon Monoxide in 1991 . . . . . 99

39. Ozone Nonattainment Areas and Related Air Quality Classification, $1991 \ldots \ldots \ldots \ldots \ldots \ldots$

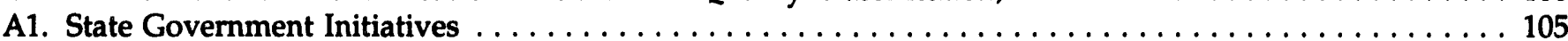

B1. Methodology for Reporting Alternative Fueled Vehicle and Replacement Fuel Data . . . . . . . . . . . 120

B2. Summary of Information on Data Quality for Non-Federal Alternative Fueled Vehicles . . . . . . . . . 121

E1. Atmospheric Reactivity, Vapor Pressure, and Octane Numbers of Selected Hydrocarbons

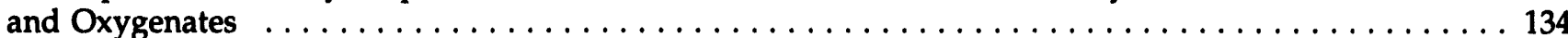


1. Distribution of Light-Duty Vehicle Fleets by Use, $1992 \ldots \ldots \ldots \ldots \ldots \ldots \ldots \ldots \ldots \ldots \ldots \ldots$

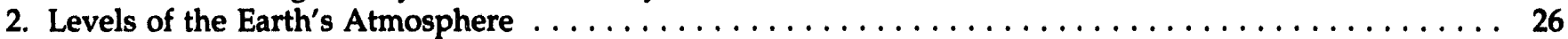

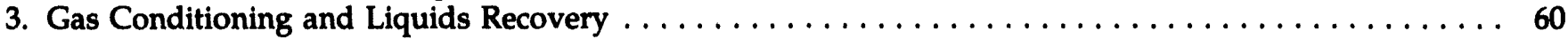

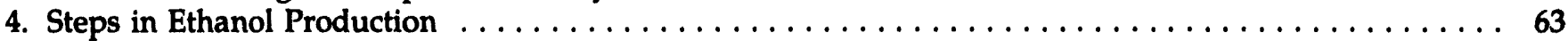

5. Typical CNG Vehicle Refueling Station with Fast-Fill and Slow-Fill Systems $\ldots \ldots \ldots \ldots \ldots \ldots \ldots 6$

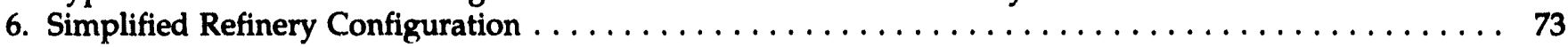

7. Distribution of Refined Petroleum Products $\ldots \ldots \ldots \ldots \ldots \ldots \ldots \ldots \ldots \ldots \ldots \ldots \ldots \ldots \ldots \ldots$

E1. Chemical Structure of Selected Alternative Fuel Hydrocarbons and Alcohols $\ldots \ldots \ldots \ldots \ldots \ldots \ldots 132$

E2. Structure of Major Hydrocarbons in Gasoline $\ldots \ldots \ldots \ldots \ldots \ldots \ldots \ldots \ldots \ldots \ldots \ldots \ldots \ldots \ldots$

F1. Entire Fuel Cycle for Transportation Fuels: Physical Flow Diagram-Mobile Source Emissions . . . . 136 


\section{Executive Summary}

\section{Purpose of the Report}

Section 503 of the Energy Policy Act of 1992 (EPACT) requires the Energy Information Administration (EIA) to report on specific aspects of the alternative transportation fuels industry. ${ }^{1}$ EIA must report annually on: (1) the number and type of alternative fueled vehicles in existence the previous year and expected to be in use the following year, (2) the geographic distribution of these vehicles, (3) the amounts and types of replacement fuels consumed, ${ }^{2}$ and (4) the greenhouse gas emissions likely to result from replacement fuel use.

This report precedes the first such report required by EPACT. It has two purposes: (1) to provide background information on alternative transportation fuels and replacement fuels, and (2) to furnish preliminary estimates of the use of these fuels and of alternative fueled vehicles. The report is based primarily on information from secondary sources. ${ }^{3}$ It does not fully cover some topics required by Section 503 because reliable information is lacking.

\section{Background}

In the 1970s, two major oil price increases sparked a desire to develop alternative transportation fuels as insurance against petroleum shortages and high prices. Subsequent lower petroleum prices, plentiful supplies, and higher costs of alternative fuels caused interest to wane.
Now, the United States is renewing its attention to transportation fuels that might replace gasoline and diesel fuel. The current effort is directed at improving air quality as well as increasing domestic energy security. Alternative fuels-and the vehicles powered by them-are viewed as ways to reduce harmful air pollutants and greenhouse gases.

The use of alternative fuels and alternative fueled vehicles is expected to be legislatively driven for some time, for a number of reasons. ${ }^{4}$ Accordingly, a brief discussion of the principal legislation directed at the twin concerns of air pollution and energy security is presented here.

The course for reducing air pollution through reformulating transportation fuel was set by the Clean Air Act Amendments of 1990, which set goals for improving air quality, especially for carbon monoxide and ozone in the transportation sector. ${ }^{5}$ The law regulates both transportation fuel content and allowable air pollutant levels. It is viewed as favorable for alternative transportation fuels, especially the simpler "hydrocarbons" such as natural gas (methane).

The clean air initiatives of the Amendments have had a more immediate impact on the use of alternative transportation fuels than have energy security concerns addressed in EPACT, especially with petroleum prices currently at low real levels. States and cities are also participating in alternative-fuel-related clean air programs. For example, the California Air Resources Board has issued more stringent emission guidelines for

\footnotetext{
${ }^{1}$ As defined in EPACT, "the term 'alternative fuel' means methanol, denatured ethanol, and other alcohols; mixtures containing 85 percent or more (or such other percentage, but not less than 70 percent, as determined by the Secretary of Energy, by rule, to provide for requirements relating to cold-start, safety, or vehicle functions) by volume of methanol, denatured ethanol, and other alcohols with gasoline or other fuels; natural gas; liquefied petroleum gas; hydrogen; coal derived liquid fuels; fuels (other than alcohol) derived from biological materials; electricity (including electricity from solar energy), and any other fuel the Secretary determines, by rule, is substantially not petroleum and would yield substantial energy security benefits and substantial environmental benefits."

${ }^{2}$ Replacement fuels are a broader category than alternative fuels and include alternative fuels. As defined in EPACT, "the term 'replacement fuel' means the portion of any motor fuel that is methanol, ethanol, or other alcohols, natural gas, liquefied petroleum gas, hydrogen, coal derived liquid fuels, electricity (including electricity from solar energy), ethers, or any other fuel the Secretary of Energy determines, by rule, is substantially not petroleum and would yield substantial energy security benefits and substantial environmental benefits."

"Secondary sources" are those other than EIA data survey forms. Accordingly, EiA cannot always determine the quality of such information.

${ }^{4}$ Most alternative fueled vehicles cost more to produce than conventional vehicles, require different refueling capabilities, and may have inferior performance characteristics.

${ }^{5}$ The original Clean Air Act was enacted in 1963 and first amended in 1977.
} 
"mobile source emissions" than are contained in the Clean Air Act Amendments. Many States, especially in the Northeast, are considering adopting the California standards for vehicle emissions and fuel content. Some cities are participating in a "Clean Cities" program, in cooperation with the Federal Government. The program coordinates purchases of alternative fueled vehicles ly local governments and private companies and encourages the development of the necessary refueling infrastructure (i.e., the systems and equipment used to dispense fuel into a vehicle's fuel tank).

Congress enacted EPACT in the wake of the Persian Gulf conflict of 1990-91. EPACT addresses virtually every aspect of the U.S. energy industry. While many facets of the final version of EPACT had been under consideration for some time, sharply higher oil prices and loss of a major Middle East petroleum supply source again raised energy security concerns. ${ }^{6}$ This concern is reflected several places in ElPACT, especially in Section 502, which requires the Secretary of Energy to "establish a program ... to the extent practicable, [to] ensure the availability of those replacement fuels that will have the greatest impact in reducing oil imports, improving the health of our Nation's economy and reducing greenhouse gas emissions."

Because alternative transportation fuels require different refueling infrastructures, vehicle fuel storage mechanisms, and engine and emission control technologies than gasoline or diesel fuel, their widespread introduction is perceived to need special assistance. This is particularly true since many alternative fueled vehicles are viewed as more costly than their traditional fuel counterparts. EPACT therefore targets fleets for increasing use of alternative fueled vehicles. Fleets usually refuel at centralized locations, minimizing the number of new refueling facilities required. EPACT mandates acquisition targets for alternative fueled vehicles for Federal and State agencies, as well as for alternative fuel providers. It also directs the Department of Energy to provide financial support for Federal agencies to purchase these vehicles.

In addition, EPACT promotes renewable energy and vehicles that run on nontraditional fuels by:

- Establishing minimum alternative fueled vehicle purchase requirements for Federal and other government fleets ${ }^{9}$

- Making all alternative fueled vehicles eligible for fuel economy credits in the Corporate Average Fuel Economy program ${ }^{10}$

- Offering low-interest loans to purchasers of alternative fueled vehicles ${ }^{11}$

- Conducting a detailed study of replacement fuel supply and determining the feasibility of reaching specified production goals for the fuels ${ }^{12}$

- Requiring the Department of Energy to establish a commercial demonstration program with financial support for electric motor vehicles

- Mandating alternative fuel providers to purchase alternative fueled vehicles

- Establishing tax-deductible credits for purchasers of alternative fueled vehicles and refueling station owners. $^{13}$

\section{Enumeration of Alternative Fueled Vehicles}

In 1992, there were 2,240 Federal alternative fueled vehicles and nearly 248,000 non-Federal vehicles (Table ES1), compared with the total U.S. vehicle population of nearly 180 million. ${ }^{14}$ Almost 85 percent of nonFederal alternative fueled vehicles are private-sector vehicles fueled by liquefied petroleum gas (commonly

'Substantially higher prices were sustained for only a brief period.

7Title III of EPACT also addresses energy security by permitting the Secretary of Energy to designate, by rule, as an "alternative fuel" any fuel which is substantially not petroleum and would yield substantial energy security benefits and substantial environmental benefits.

Originally, financial support was provided under the Alternative Motor Fuels Act of 1988. EPACT expanded some provisions of this Act.

Table 20 in this report shows the Feteral vehicle acquisition targets. They are based on Executive Order 12844, which expanded the counts established in Section 303 of EPACT by 50 percent.

${ }^{10}$ EPACT was not the first rule to make alternative fuel vehicles eligible for credits under the Corporate Average Fuel Economy program. The Chrysler Corporation Loan Guarantee Act of 1979 (Public Law 96-185) added a new subsection to the Motor Vehicle Information and Cost Savings Act which makes certain fuels eligible for credits. This provision was expanded first in the Alternative Motor Fuels Act and then in EPACT.

"Section 414 of EPACT directs preference to be given to fleets where the use of alternative fuels would significantly benefit energy security and the environment.

${ }^{12}$ The production goals are 10 percent of motor fuel (on an energy equivalent basis) in 2000 and 30 percent in 2010 . At least half of these amounts must be from domestic sources.

${ }^{13}$ The tax credit is available through 2004.

${ }^{14}$ Alternative fueled vehicle counts for some categories represent fleets above certain minimum sizes. 
Table ES1. Estimated Number of Alternatlve Fueled Vehicles by Ownership Class, 1992

\begin{tabular}{|c|c|c|c|}
\hline Fuel & \multicolumn{3}{|c|}{ Ownershlp Class } \\
\hline $\mathrm{LPG}^{2} \ldots \ldots \ldots \ldots \ldots$ & 20 & $>11,000$ & $>209,500$ \\
\hline$\ldots \ldots \ldots \ldots \ldots$ & 1,978 & 4,700 & 17,800 \\
\hline$M-85^{3} \ldots$ & 220 & 2,521 & 27 \\
\hline Electricity $\ldots \ldots \ldots \ldots$ & $-\cdot$ & 101 & 1,589 \\
\hline$M-100^{5} \ldots \ldots \ldots \ldots$ & -- & 398 & 6 \\
\hline$E-95^{\circ} \ldots \ldots \ldots \ldots \ldots$ & $\cdots$ & 25 & 13 \\
\hline LNG . . . . . . . . . . & -- & 71 & 19 \\
\hline
\end{tabular}

'Data from the General Services Administration agencies (Interagency Fleet Management Svatem and Automotive Commodity Center) plus the Federal agencies' own vehicles that were retrofitted during the year are included. Data are based on actual vehicle counts in place as of year-end 1992.

${ }^{2}$ The actual number of vehicles for State and local governments and for the private sector may be as much as 50 percent greater. The estimates reported indicated a lower limit.

${ }^{3} \mathrm{~A}$ fuel mixture of 85 percent methanol and 15 percent gasoline.

${ }^{4} A$ fuel mixture of 85 percent ethanol and 15 percent gasoline.

${ }^{5} \mathrm{~A}$ fuel consisting of 100 percent methanol.

${ }^{8} \mathrm{~A}$ fuel mixture of 95 percent ethanol and 5 percent gasoline.

${ }^{7} A$ diesel-fuel substitute made from vegetable oils (methyl ester) or animal tallow (methyl tallowate).

Notes: Fuel terms are defined in the Glossary. LPG, liquefied petroleum gas (propane); CNG, compressed natural gas; LNG, liquefied natural gas. Data conform with information compiled by the Alternative Fuel Data Center at the National Renewable Energy Laboratory.

Sources: Federal: General Services Administration (Interagency Fleet Management System and Automotive Commodity Center) and Federal agencies. State/local Government and Private: Science Applications International Corporation, Alternative Transportation Fuels and Vehicles Data Development, April 11, 1994, Task No. 93-112, Contract Number DE-AC01-92El21948.

known as propane). Propane fueled more than 11,000 State and local government vehicles in 1992. Propane has been extensively used as a road fuel for several decades. Relatively modest growth is forecast for lightduty propane vehicles, despite some favorable operating and emission characteristics. About 2,000 new heavy-duty and 9,000 light-duty propane vehicles will be in service by the end of 1994 .

In 1992, more Federal government-owned alternative fueled vehicles ran on compressed natural gas than on any other alternative fuel-approximately 2,000. Compressed natural gas also fueled 4,700 State and local government vehicles, second to propane. In addition, compressed natural gas vehicles represented the second-largest number of alternative fueled vehicles in the private sector. The use of compressed natural gas vehicles is expected to grow sharply, because domestic supplies of natural gas are abundant and fuel costs are low, as are emissions. More than 30,000 additional compressed natural gas vehicles are expected to be on the road in 1994. The need for much larger fuel tanks than those for gasoline to drive the same range poses a design challenge for compressed natural gas vehicles.

Methanol/gasoline blends (either 85 percent methanol, 15 percent gasoline or 100 percent methanol-known as $M-85$ and M-100, respectively) fueled roughly 3,200 alternative fueled vehicles in 1992. Most of those vehicles are in California; many are transit buses. About 10,000 new methanol vehicles are expected to be in service through 1994. Nearly all of these will be M-85 vehicles. Governments are expected to acquire almost all of the increase.

Ethanol, in "near neat" forms like E-85 and E-95, is primarily used in demonstration alternative fueled vehicles. Most ethanol is used in low'-volume, oxygenat- 
ing blends with gasoline in proportions of 10 percent (gasohol), 7.7 percent, and 5.7 percent. EPACT classifies E-85 and E-95 as "replacement" fuels for the purpose of meeting the EPACT conventional motor fuel displacement goals. Ethanol-powered vehicles are expected to remain largely in State and local government demonstration programs through 1994.

Although not yet commercially used, biodiesel may offer environmental improvements in powering compression-ignition (e.g., diesel) engines. ${ }^{15}$ Biodiesel is produced from biomass products such as soy or rapeseed oil.

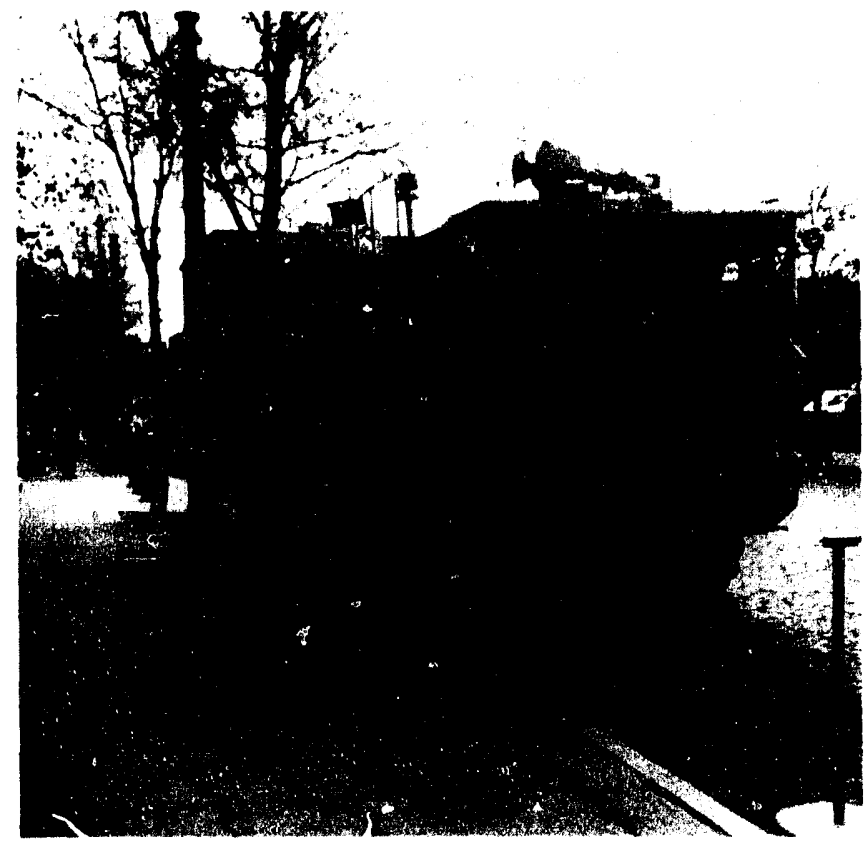

This tiis truck is po:siered with biodiesel fuel made from soybeans.

The majority of electric vehicles in the private sector are private conversions not designed for the rigors of commercial us2. Restricted range (60 to 80 miles) and production cost are the greatest challenges to widespread acceptance of electric vehicles. Of the nearly 1,700 electric vehicles, private fleets operate all but about 100 , with the remainder operated by State and local governments. Within the private sector, many electric and gas utilities operate electric vehicles more for "demonstration" purposes than for regular-duty use. However, California is trying to introduce electric vehicles into the mainstream of surface transportation.
Beginning in 1998, California will require an increasing percentage of manufacturers' vehicle sales to be "zeroemission vehicles." ${ }^{16}$ So far, only electric vehicles meet the zero-emission vehicle criteria. ${ }^{17}$ Growth in electric vehicles through 1994 is largely restricted to the private sector.

In analyzing the above information, it is important to note that EPACT was enacted in late 1992 and therefore had little impact on 1992 aiternative fueled vehicle penetration. Clearly, the impact of EPACT will be felt in subsequent years, pariticularly since Executive Order 12844 accelerated the alternative fueled vehicle purchase timetable specified in EPACT. Also, the Clean Air Act Amendments of 1990 require certain urban areas to attain specified air quality standards by the late 1990s. As mentioned earlier, alternative fueled vehicles are believed to have emission characteristics that will facilitate meeting those standards.

\section{Alternative and Replacement Fuel Consumption}

Alternative fuels accounted for 0.1 percent of total 1992 U.S. on-road fuel use of roughly 136 billion gasolineequivalent gallons (Table ES2). Propane provided 97.4 percent of alternative fuels consumption (on a gasolineequivalent basis). Replacement fuel consumption, excluding alternative fuels, accounted for 1.4 percent of on-road fuel consumption in $1992 .{ }^{18}$ Nearly two-thirds was methyl tertiary-butyl ether, which is used as an oxygenate in gasoline to limit ozone formation in the summer and carbon monoxide formation in the winter.

Fuel consumption estimates, if reliable, could probably measure alternative fueled vehicle penetration into the transportation sector better than the vehicle counts presented in this report. The reason is that this report's coverage of private vehicle fleets is not comprehensive. However, using fuel consumption estimates to infer vehicle counts requires making certain assumptions. Fuel consumption is directly related to miles traveled and to vehicle efficiency. Thus, estimating vehicle counts from fuel consumption data assumes that accurate estimates of vehicle mileage use are available. Currently, reliable mileage use measurements do not exist for alternative fueled vehicles.

\footnotetext{
${ }^{15}$ Some States in the Midwest have tested biodiesel fleets of mostly leased vehicles.

${ }^{16}$ In 1998, California requires that 2 percent of the original equipment manufacture sales be electric vehicles.

${ }^{17}$ While an electric vehicle has zero emissions during vehicle operation, the electricity production portion of the electric vehicle fuel cycle creates considerable emissions.

${ }^{18}$ Replacement fuel volume for gasoline-alcohol mixtures was calculated using the volume of the gasoline additive (e.g., ethanol).
} 
Table ES2. Summary of U.S. Vehicle Fuel Consumption, 1992

\begin{tabular}{|c|c|c|}
\hline Fud & Consumption & $\begin{array}{c}\text { Gasoline Equivalent } \\
\text { (Million Gallons) }\end{array}$ \\
\hline \multicolumn{3}{|l|}{ Traditional Fuels } \\
\hline Gasoline' $^{1} \ldots \ldots \ldots \ldots \ldots \ldots \ldots$ & 110,135 million gallons & 110,135 \\
\hline Diesel $\ldots \ldots \ldots \ldots \ldots \ldots \ldots \ldots \ldots \ldots$ & 21,375 million gallons & 23,866 \\
\hline \multicolumn{3}{|l|}{ Alternative Fuols } \\
\hline $\mathbf{M}-85^{2} \ldots \ldots \ldots \ldots \ldots \ldots \ldots \ldots$ & 2 million gallons & 1 \\
\hline$\ldots \ldots \ldots \ldots \ldots \ldots \ldots \ldots \ldots$ & * & * \\
\hline$E-85^{4} \ldots \ldots \ldots \ldots \ldots \ldots \ldots \ldots \ldots$ & * & * \\
\hline$E-95^{5} \ldots \ldots \ldots \ldots \ldots \ldots \ldots \ldots$ & * & * \\
\hline LPG $\ldots \ldots \ldots \ldots \ldots \ldots \ldots \ldots \ldots$ & 250 million gallons & 184 \\
\hline CNG $\ldots \ldots \ldots \ldots \ldots \ldots \ldots \ldots$ & 511 million cubic feet & 4 \\
\hline LNG $\ldots \ldots \ldots \ldots \ldots \ldots \ldots \ldots$ & * & * \\
\hline Hydrogen . . . . . . . . . . . . . . . & * & $\star$ \\
\hline \multicolumn{3}{|l|}{ Replacement Fuels (Included in Gasoline) } \\
\hline Ethanol in Gasohol ${ }^{\beta} \ldots \ldots \ldots \ldots \ldots$ & 1,061 million gallons & 701 \\
\hline MTBE $\ldots \ldots \ldots \ldots \ldots \ldots \ldots \ldots$ & 1,445 million gallons & 1,175 \\
\hline
\end{tabular}

"Value represents a negligible amount.

'Gasoline includes the replacement fuels, ethanol and MTBE.

${ }^{2} A$ fuel mixture of 85 percent methanol and 15 percent gasoline.

${ }^{3} A$ fuel consisting of 100 percent methanol.

4 A fuel mixture of 85 percent ethanol and 15 percent gasoline.

${ }^{5} A$ fuel mixture of 95 percent ethanol and 5 percent gasoline.

${ }^{6}$ A fuel mixture of 10 percent ethanol and 90 percent gasoline.

Notes: Fuel terms are defined in the Glossary. LPG, liquefied petroleum gas (propane); CNG, compressed natural gas; LNG, liquefied natural gas; MTBE, methyl tertiary-butyl ether.

Sources: Gasoline consumption: Energy Information Administration, Petroleum Supply Annual 1992, Vol. 1, DOE/EIA0340(92)/1, (Washington, DC, May 26, 1993), Table S4, adjusted to include field ethanol blended and to cover only highway uses. Highway use was estimated as 97.1 percent of total gasoline supplied, based on 1990 data published in the Transportation Energy Data Book: Edition 13, prepared by Oak Ridge National Laboratory for the U.S. Department of Energy (Oak Ridge, TN, March 1993), Table 2.7. Highway dlesel consumption: Energy Information Administration, Fuel Oil and Kerosene Sales 1991, DOE/EIA0535(91) and Fuel Oil and Kerosene Sales 1992, DOE/EIA-0535(92); and Federal Highway Administration, Statistics of Highway Special Fuels Use, Table 1. M-85: California Energy Commission (facsimile provided). CNG: Energy Information Administration, Natural Gas Annual 1992, DOE/EIA-031(92) (Washington, DC, December 1992), Table 1. LPG: Estimated as 50 percent of engine fuel reported by American Petroleum Institute, 1992 Sales of Natural Gas Liquids and Liquefied Refinery Gases (Washington, DC, October 1993), which shows a total of 500 million gallons engine fuel use. Ethanol and MTBE: Energy Information Administration, Petroleum Supply Monthly, DOE/EIA-0109(93/01) (Washington, DC, January 1993), Appendix D.

\section{Greenhouse Gas Emissions}

Greenhouse gases are those that either: (1) absorb heat or prevent its release into the stratosphere and beyond, thus warming the Earth or (2) reflect sunlight, preventing its entry into the troposphere and striking the
Earth's surface, thus cooling the Earth. The Earth's capacity to support life depends on the moderating influences of these gases. Increases in certain greenhouse gases are thought to contribute to global warming. Greenhouse gases are released into the atmosphere as a result of a large number of natural and human ${ }^{19}$

\footnotetext{
${ }^{19}$ Human activity is sometimes referred to "anthropogenic" activity.
} 
activities. A major human source of greenhouse gases is energy production and consumption. Mobile sources (e.g., automobiles, trains, ships) emit about 30 percent of all man-made greenhouse gases in the United States. Concerns about global warming are motivating the use and continuing development of replacement fuels that have favorable characteristics on a fuel-cycle basis for reducing greenhouse gases.

The life-cycle impact of replacement fuels on greenhouse gas emissions is not certain. Measuring actual emissions over the entire fuel cycle is extremely difficult. Even in the combustion phase, for which emission tracking is more common, it is much more difficult to measure emissions for traveling vehicles than for stationary electric power plants. Projecting the global warming impact (if any) using emission estimates adds an additional level of complexity.

Addressing this problem requires first determining which greenhouse gases are emitted as a result of producing and using each fuel. The next step is to determine whether a given fuel produces more or less of a $\mathrm{p} z$ ticular greenhouse gas than do conventional fuels (Table ES3). While no replacement fuel appears to have uniformly lower greenhouse gas emissions than gasoline, methyl tertiary-butyl ether, propane, and compressed natural gas produce less carbon dioxide and carbon monoxide.

The emissions information in Table ES3 should be viewed with two caveats. First, the fuel-cycle emissions data presented for greenhouse gases from alternative fuels versus gasoline are only qualitative in nature. The EIA is currently researching methods to develop reliable quantitative estimates of oreenhouse gases for future reports. Second, much of the concern about emissions centers on air quality in areas with high population densities. For this purpose, tailpipe (i.e., combustion phase) and refueling emissions are of greatest interest. The EIA will attempt to include information in future reports for combustion-phase emissions, as well as for other components of the fuel cycle. 
Table ES3. Total Fuel-Cycle Emissions from Gasoline and from Replacement Fuels

\begin{tabular}{|c|c|c|c|c|c|c|c|}
\hline \multirow[b]{2}{*}{ Emissions } & \multirow{2}{*}{$\begin{array}{c}\text { From } \\
\text { Gasoline }\end{array}$} & \multicolumn{6}{|c|}{ From Replacoment Fuels, Relative to Gasoline } \\
\hline & & MTBE' & Ethanol ${ }^{2}$ & LPG & CNG & M-85 & Electric ${ }^{3}$ \\
\hline \multicolumn{8}{|l|}{ Greenhouse Gases` } \\
\hline Water Vapor ............. & Yes & More & More & More & More & More & Loss \\
\hline Carbon Dioxide $\left(\mathrm{CO}_{2}\right)^{5} \ldots \ldots \ldots$ & Yes & Less & Less & Less & Less & Less & a \\
\hline Carbon Monoxide (CO) & Yes & Less & Equal/Less & Less & Less & Equal & Less \\
\hline Nitrogen Oxides $\left(\mathrm{NO}_{x}\right)^{6}$ & Yes & Equal & More/Equal ${ }^{7}$ & Equal & Equal & Equal & a \\
\hline Nitrous Oxide $\left(\mathrm{N}_{2} \mathrm{O}\right) \ldots \ldots$ & Yes & a & a & a & a & a & a \\
\hline \multicolumn{8}{|l|}{ Volatile Organic Compounds" } \\
\hline Methan $\theta^{\circ}$ & Yes & Equal & Equal & More & More & Equal & Less \\
\hline Ethan $\theta^{10}$ & Yes & Equal & Equal & Equal & Equal & Equal & Less \\
\hline Total Ozone Precursors" & Yes & Less & More/Less ${ }^{12}$ & Less & Less & Less & Less \\
\hline \multicolumn{8}{|l|}{ Nonmethane Organic Compounds } \\
\hline Methanol $\ldots \ldots \ldots \ldots \ldots$ & No & More & No & No & No & More & No \\
\hline Ethanol $\ldots \ldots \ldots \ldots \ldots \ldots$ & No & No & More & No & No & No & No \\
\hline Formaldehyde $\ldots \ldots \ldots \ldots$ & Yes & More & More & Equal & Equal & More & Less \\
\hline Acetaldehyde $\ldots \ldots \ldots \ldots \ldots$ & Yes & Less & More & Less & Equal & Equal & Less \\
\hline${\text { Sulfur } \text { Oxides }^{13} \ldots \ldots \ldots \ldots}{ }^{13} \ldots \ldots$ & Yes & Less & Less & No & No & Less & More \\
\hline Particulate Matter ${ }^{14} \ldots \ldots \ldots$ & Yes & Less & Less & Less & No & No & More \\
\hline
\end{tabular}

${ }^{a}$ Results are uncertain because emissions vary widely, depending on the engine's compression, temperature, and fuel/oxygen mix.

${ }^{1}$ Consumed with the gasoline in which it was blended.

${ }^{2}$ Includes ethanol in gasohol and ethanol as E-85.

${ }^{3}$ Life-cycle emissions from electric vehicles depend on the utility feedstock; these projections assume that the feedstock is mostly coal, as more than half of electricity today is generated from coal.

"Greenhouse gas emission impacts are highly dependent on the feedstock used for fuel production.

${ }^{5} \mathrm{CO}_{2}$ emissions vary widely. In some cases, emissions could be either higher or lower than gasoline, depending on the feedstock and method of production.

${ }^{6}$ Nitrogen oxides are not a direct greenhouse gas but rather contribute through tropospheric ozone formation.

${ }^{7}$ More for splash-blended gasohol with higher Reid vapor pressure; equal for gasohol with controlled Reid vapor pressure (not splash-blended) and for E-85/E-100.

${ }^{8}$ Methane and ethane are just two of hundreds of volatile organic compounds. Others, such as hydrocarbons from unburned fuel and partial combustion, are not reported here.

Does not participate in atmospheric photochemical reactions.

${ }^{10}$ Does not participate in atmospheric photochemical reactions.

${ }^{11} \mathrm{Ozone}$ precursors include $\mathrm{NO}_{\mathrm{x}}$ and nonmethane organic compounds.

${ }^{12}$ More if splash-blended gasohol but less if specially reformulated gasohol or E-85/E-100.

${ }^{13}$ This category includes sulfones. While most greenhouse gases contribute to global warming, the sulfates cool the atmosphere. Among the transportation fuels, sulfur oxides are emitted mostly from diesel fuel.

${ }^{14}$ Most particulate matter emissions in the transportation sector come from diesel fuel.

Notes: MTBE, methyl tertiary-butyl ether; LPG, liquefied petroleum gas (propane); CNG, compressed natural gas.

Sources: See Appendix D, references 16 through 20. 
Section 1

Alternative Fuels Data 


\section{Introduction}

This report, Alternatives to Traditional Transportation Fuels: An Overview, presents the first compilation by the Energy Information Administration (EIA) of information on alternatives to gasoline and diesel fuel. The purpose of the report is: (1) to provide background information on alternative transportation fuels ${ }^{20}$ and replacement fuels ${ }^{21}$ compared with gasoline and diesel fuel, and (2) to furnish preliminary estimates of alternative transportation fuels and alternative fueled vehicles $^{22}$ as required by the Energy Policy Act of 1992 (EPACT), Title V, Section 503, "Keplacement Fuel Demand Estimates and Supply Information." Specifically, Section 503 requires the EIA to report annually on: (1) the number and type of alternative fueled vehicles in existence the previous year and expected to be in use the following year, (2) the geographic distribution of these vehicles, (3) the amounts and types of replacement fuels consumed, and (4) the greenhouse gas emissions likely to result from replacement fuel use. Alternative fueled vehicles are defined in this report as motorized vehicles licensed for on-road use, which may consume alternative transportation fuels. (Alternative fueled vehicles ${ }^{23}$ may use either an alternative transportation fuel or a replacement fuel.)

Information in this report should be considered preliminary because available data are limited. However, EIA wishes to provide energy decisionmakers with the most accurate information currently existing in these areas. Later reports should benefit from greater availability of survey-based data and be more comprehensive. The intended audience for the first section of this report includes the Secretary of Energy, the Congress, Federal and State agencies, the automobile manufacturing industry, the transportation fuel manufacturing and distribution industries, and the general public. The second section is designed primarily for persons desiring a more technical explanation of and background for the issues surrounding alternative transportation fuels.

\section{Background}

Alternative transportation fuels (ATFs) have been used for several decades in specialized applications. After each of the world oil crises (1973 and 1979), there was a flurry of activity to determine if a suitable domestic replacement for crude-based transportation fuels existed. Of all the fuels tried, none was considered practical except liquid petroleum gas (LPG), ${ }^{24}$ principally in heavy-duty vehicles.

While there are currently no apparent economically' viable substitutes to replace gasoline on a widespread basis, environmental concern about the effects of transportation fuel emissions became a major issue during the 1980s. After oil prices escalated sharply (but briefly) during the Persian Gulf conflict, energy security concerns resurfaced. Thus, both air quality and energy security issues are driving the current interest in ATFs. Following is a section on each topic, including legislative history, as it applies to ATFs.

\section{Energy Security}

EPACT was designed to meet the energy challenges of the 21st century. It was the first major legislative attempt to curb U.S. dependence on foreign oil in over a decade, being enacted in the wake of the Persian Gulf conflict of 1990-91. EPACT touches virtually every sector of the energy industry. It establishes a national goal of displacing 30 percent of the petroleum content of fuels for light-duty motor vehicles with non-petroleum-derived replacement fuels by 2010 . At least half of this amount must come from domestic resources.

While many facets of the final version of EPACT had been under consideration for some time, sharply higher oil prices during 1990-91 and loss of a major Middle

\footnotetext{
${ }^{20}$ Alternative transportation fuels, as defined by EPACT, include methanol and ethanol mixtures containing 85 percent or more by volume of methanol or ethanol with gasoline or other fuels, compressed natural gas, liquefied natural gas, liquefied petroleum gas, electricity, and hydrogen.

${ }^{21}$ Replacement fuels are defined by EPACT to include fuels that contain methanol and ethanol or other alcohols, compressed natural gas, liquefied natural gas, liquefied petroleum gas, electricity, hydrogen, and ethers.

${ }^{22}$ This report follows EPACT terminology regarding "alternative fueled vehicles" rather than the option, "alternatively fueled vehicles."

${ }^{23}$ Alternative fueled vehicles are defined in Section 301 of EPACT.

${ }^{24} \mathrm{LPG}$ is commonly known by its principal component, propane.
} 
East petroleum supply source raised concerns over domestic and foreign oil supplies. This concern is reflected several places in EPACT, especially in Section 502. Among other mandates, Section 502 requires the Secretary of Energy to "establish a program ... to the extent practicable, [to] ensure the availability of those replacement fuels that will have the greatest impact in reducing oil imports, improving the health of our Nation's economy and reducing greenhouse gas emissions. ${ }^{\prime 25}$

Titles III, IV, and V of EPACT further promote the use of ATFs and alternative fueled vehicles (AFVs) by establishing broad guidelines and incentives for AFV use. EPACT expands the number of Alternative Motor Fuels Act categories (ethanol, methanol, and natural gas) to include LPG, coal-derived liquid fuels, hydrogen, and electricity. The result is that more fuels are planned for the Federal Government light-duty vehicle program in 1994. In addition, EPACT adds a statutory requirement for the wide adoption of alternative fueled vehicles in government and alternative fuel provider fleets. The EPACT Federal fleet requirements have been amplified by Executive Order 12844, which directs Federal Government agencies to exceed the EPACT alternative fuel vehicle acquisition requirements by 50 percent.

\section{Air Quality}

Increasing concern over the impact of emissions from the combustion of hydrocarbon fuels has focused on two areas. The first area is emissions harmful ${ }^{26}$ to human health. A major focus in this area is atmospheric ozone $^{27}$ and the substances which form it (known as "precursors"). Ozone is a powerful irritant to human respiratory systems. While controlling harmful air pollutants is the primary focus of much of the air quality legislation impacting the transportation sector, greenhouse gas emissions are the only air quality issue addressed in Section 503 of EPACT. Accordingly, further discussion on harmful pollutants is reserved for Chapter 10.

Greenhouse gases produced by the transportation sector are of concern ${ }^{28}$ because they may contribute to global warming ${ }^{29}$ in at least three ways: (1) direct heat of the gases from fuel combustion warms the air and the Earth, (2) greenhouse gases resulting from fuel combustion may "trap" radiation from the sun that would otherwise radiate back into space, and (3) depletion of stratospheric ozone by virulent greenhouse gases allows more radiation to penetrate the troposphere and reach the Earth's surface, this warming the Earth. Water vapor, carbon dioxide, and nitrogen oxides are three of the most prevalent greenhouse gases. Emissions of methane, the dominant biogenic greenhouse gas, do vary considerably by transportation fuel choice.

Legislative acts primarily responsible for limiting emissions and spurring research, development, and implementation of ATFs and replacement fuels are: (1) the Clean Air Act of 1963 (Public Law 88-206) and its subsequent amendments, (2) the Alternative Motor Fueis Act of 1988 (Public Law 100-494), (3) the Energy Policy Act of 1992 (Public Law 102-486), and most recently (4) Executive Order 12844, signed by President Clinton in April 1993..$^{30}$ The first two Acts will now be summarized in turn. A complete discussion of all relevant legislation can be found in Chapter 5 . Water vapor and carbon dioxide concentrations are relatively unaffected over the entire fuel cycle by alternative fuel choice. ${ }^{31}$

The Clean Air Act Amendments of 1990 (CAAA) authorized the U.S. Environmental Protection Agency (EPA) to set National Ambient Air Quality Standards (NAAQS) $^{32}$ to address air pollution and designated

\footnotetext{
${ }^{25}$ Title III of EPACT also addresses energy security by permitting the Secretary of Energy to designate, by rule, as an "alternative fuel" any fuel that is substantially not petroleum and would yield substantial energy security benefits and substantial environmental benefits.

${ }^{26}$ The term "toxic" has at least two different technical definitions and generally will be avoided in this report in order to avoid confusion

${ }^{27}$ The "ozone layer," which shields dangerous rays of the sun from the earth, is located in the stratosphere and is not at issue here.

${ }^{28}$ Ground-level ozone is the primary component of smog. In contrast, the causal relationships between vehicular emissions and global warming are being investigated, with some results appearing to support different effects from those originally hypothesized. Studies across the entire fuel cycle of each transportation fuel reveal a complex interrelationsi.ip of atmospheric, water, and land effects. So far, definitive conclusions regarding the impact of greenhouse gases on global climate are still scientifically tenuous.

${ }^{29}$ Certain greenhouse gases are also harmful to human health.

${ }^{30}$ Executive Order 12759, signed April 17, 1991, also affected AFV efforts. On transportation issues it required: (1) a 10-percent reduction in Federal usage of gasoline and diesel fuel by 1995, and (2) purchase of a number of AFVs produced by original equipment manufacturers each year to 1995.

${ }^{31} \mathrm{Net}$ carbon dioxide emissions from biomass-derived fuels are near zero because the quantity of carbon dioxide removed during biomass renewal is nearly equivalent to the quantity emitted during fuel combustion.

${ }^{32}$ The major air pollutants for which NAAQS have been designated under CAAA are carbon monoxide, lead, nitrogen dioxide, ozone, particulate matter, and sulfur dioxide.
} 


\section{Transportation Fuel Options}

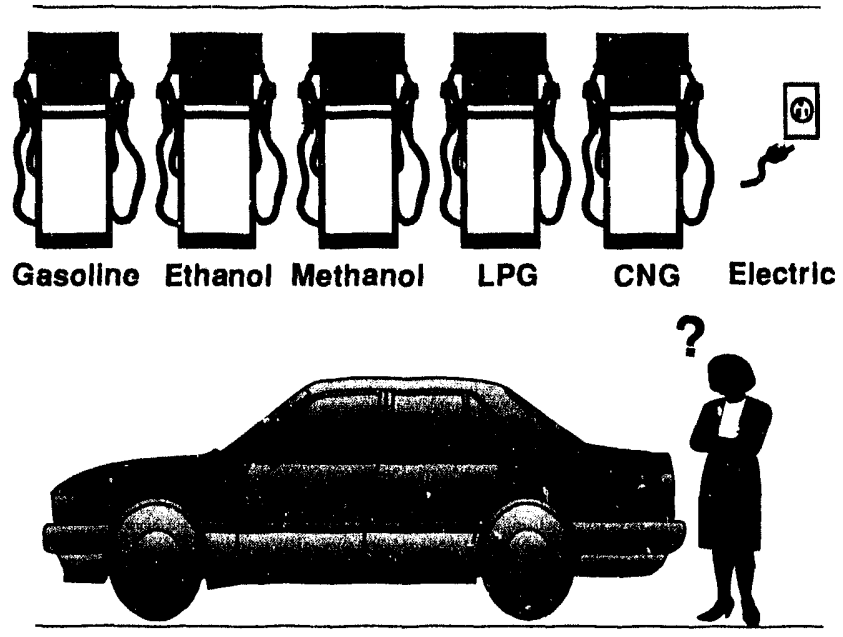

standards to mediate carbon monoxide and ozone levels. To help States meet the standards for ozone, carbon monoxide, and other pollutants, the CAAA included requirements designed to reduce the amount of mobile-source pollutants from traditional transportation fuels. Standards include fuels and vehicle operating characteristics as well as alternative transportation programs, such as ridesharing, use of commuter trains, etc., aimed at reducing highway traffic in seriously polluted areas. Additionally, tailpipe emission standards for cars, buses, and trucks have become increasingly stringent, as have the testing requirements for vehicle inspection and maintenance programs.

The CAAA included specific requirements for cleaner fuels (e.g., reformulated gasoline), as well as several provisions encouraging other cleaner fuels. The CAAA also opened up the market to nonpetroleum additives. These provisions modified the content of gasoline and established stricter emission standards for vehicles in designated nonattainment areas or localities that do not meet Federal health-based air quality standards within designated timeframes.

The CAAA require each State to develop a State Implementation Plan. These plans commit States to develop a broad range of specific air pollution control programs and to estimate the emission reduction benefits of each program. In nonattainment areas, the State plan describes how the area will achieve compliance.

Subsequent acts and directives complement the Clean Air Act legislation. The Alternative Motor Fuels Act of 1988 (AMFA) was designed to help ATFs toward the threshold level of commercial application and consumer acceptability by gaining leverage through the Federal fleet program. The Act authorized the U.S. Department of Energy (DOE) to pay Federal agencies the incremental purchase cost difference between standard vehicles and AFVs of the same type. Also under this Act, DOE developed an expanded emissions test plan for the light-duty vehicle fleet to determine the difference in vehicle umissions between vehicles using alternative fuels and conventional fuels. The AMFA progran was later expanded under EPACT. ${ }^{33}$

\section{Report Content}

This publication is divided into two sections. The first (Chapters 1 through 4) discusses available data on alternative fueled vehicles, consumption of fuel, greenhouse gas emissions, and replacement fuels in the United States. Within the first section, Chapter 2 contau 13 information on AFV inventories. AFV counts are separated into Federal and non-Federal categories, with non-Federal tallies further categorized by ownership classifications. Chapter 3 provides consumption levels for traditional and nontraditional transportation fuels. Chapter 4 presents information on how replacement fuels affect greenhouse gas emissions when compared with traditional (conventional) transportation fuels.

The second section (Chapters 5 through 10) is more technical in nature. Chapter 5 provides detailed information on legislation affecting alternative transportation fuels and vehicles: the Clean Air Act Amendments, Alternative Motor Fuels Act, and Energy Policy Act. Chapter 5 also discusses the EPA's role in regulating emissions. Subsequent chapters (6 and 7$)$ discuss the technical properties of alternative, traditional, and replacement transportation fuels. Chapter 8 discusses the various types of vehicle/engine categories. Chapter 9 furnishes material on emerging fuel resources Thapter 10 provides details on greenhouse gases, as $\backslash$ ell as harmful emissions. Because the report contains a great deal of information pertaining to alternatives to transportation fuels, an index is provided for crossreferencing the fuels (Table 1).

\footnotetext{
${ }^{33}$ Executive Order 12759 also helped to expand the Alternative Motor Fuels Act efforts.
} 


\begin{tabular}{|c|c|c|c|c|c|c|c|c|c|c|}
\hline \multirow[b]{2}{*}{ Hem } & \multicolumn{8}{|c|}{ Ariesneth : Areplecement Fuels } & \multicolumn{2}{|c|}{$\begin{array}{l}\text { Alcohols and Ethers as } \\
\text { Replacoment Fuols in }\end{array}$} \\
\hline & Hydrogen & $\begin{array}{c}\text { Compreseed } \\
\text { Natural } \\
\text { Gas' }\end{array}$ & $\begin{array}{l}\text { Liquefied } \\
\text { Petroloum } \\
\text { Gas }\end{array}$ & Mothanol & Ethanol & Electrictiy & Biodlecel & $\begin{array}{c}\text { Coost- } \\
\text { Dorived } \\
\text { Fuels }\end{array}$ & $\begin{array}{c}\text { Oxygenated } \\
\text { Geseoline }\end{array}$ & $\begin{array}{c}\text { Retormulated } \\
\text { Gaeoline }\end{array}$ \\
\hline $\begin{array}{l}\text { Vehicles and Fuel Use } \\
\text { Vehicle Count } \\
\text { Consumption Volumes }\end{array}$ & $\begin{array}{l}\text { NA } \\
\text { NA }\end{array}$ & $\begin{array}{l}\text { Page } x i \\
\text { Page } 18 \\
\end{array}$ & $\begin{array}{l}\text { Page xi } \\
\text { Page } 18\end{array}$ & $\begin{array}{l}\text { Page xi } \\
\text { Page } 18 \\
\end{array}$ & $\begin{array}{l}\text { Page xi } \\
\text { Page } 18 \\
\end{array}$ & $\begin{array}{c}\text { Page xi } \\
\text { NA }\end{array}$ & $\begin{array}{l}\text { NA } \\
\text { NA }\end{array}$ & $\begin{array}{l}\text { NA } \\
\text { NA }\end{array}$ & $\begin{array}{c}- \\
\text { Page } 22 \\
\end{array}$ & - \\
\hline $\begin{array}{l}\text { Fuel Properties } \\
\text { Chemical Composition } \\
\text { Physical Properties } \\
\end{array}$ & $\begin{array}{l}\text { Page } 52 \\
\text { Page } 49 \\
\end{array}$ & $\begin{array}{l}\text { Page } 52 \\
\text { Page } 49 \\
\end{array}$ & $\begin{array}{l}\text { Page } 53 \\
\text { Page } 49\end{array}$ & $\begin{array}{l}\text { Page } 54 \\
\text { Page } 49\end{array}$ & $\begin{array}{l}\text { Page } 54 \\
\text { Page } 49 \\
\end{array}$ & $\begin{array}{l}\text { Page } 54 \\
\text { Page } 49\end{array}$ & $\begin{array}{l}\text { Page } 91 \\
\text { Page } 91 \\
\end{array}$ & $\begin{array}{l}\text { Page } 91 \\
\text { Page } 91\end{array}$ & $\begin{array}{l}\text { Page } 71 \\
\text { Page } 71\end{array}$ & $\begin{array}{l}\text { Page } 71 \\
\text { Page } 71 \\
\end{array}$ \\
\hline $\begin{array}{l}\text { Fuel Production and Distribution } \\
\text { Production Processes } \\
\text { Product Distribution }\end{array}$ & $\begin{array}{l}\text { Page } 59 \\
\text { Page } 63 \\
\end{array}$ & $\begin{array}{l}\text { Page } 60 \\
\text { Page } 63 \\
\end{array}$ & $\begin{array}{l}\text { Page } 60 \\
\text { Page } 64 \\
\end{array}$ & $\begin{array}{l}\text { Page } 61 \\
\text { Page } 65 \\
\end{array}$ & $\begin{array}{l}\text { Page } 62 \\
\text { Page } 65\end{array}$ & $\begin{array}{l}\text { Page } 62 \\
\text { Page } 66\end{array}$ & $\begin{array}{c}\text { Page } 91 \\
\text { NA } \\
\end{array}$ & $\begin{array}{c}\text { Page } 91 \\
\text { NA }\end{array}$ & $\begin{array}{l}\text { Page } 73 \\
\text { Page } 76 \\
\end{array}$ & $\begin{array}{l}\text { Page } 73 \\
\text { Page } 76 \\
\end{array}$ \\
\hline $\begin{array}{l}\text { EngineNohicle Systems } \\
\text { Engine Fuel Properties/Design } \\
\text { Fuel Storage } \\
\text { Vehicle Types }\end{array}$ & $\begin{array}{l}\text { Page } 90 \\
\text { Page } 89 \\
\text { Page } 89 \\
\end{array}$ & $\begin{array}{l}\text { Page } 87 \\
\text { Page } 87 \\
\text { Page } 86 \\
\end{array}$ & $\begin{array}{l}\text { Page } 86 \\
\text { Page } 86 \\
\text { Page } 86 \\
\end{array}$ & $\begin{array}{l}\text { Page } 84 \\
\text { Page } 84 \\
\text { Page } 84 \\
\end{array}$ & $\begin{array}{l}\text { Page } 84 \\
\text { Page } 84 \\
\text { Page } 84 \\
\end{array}$ & $\begin{array}{l}\text { Page } 88 \\
\text { Page } 88 \\
\text { Page } 88 \\
\end{array}$ & $\begin{array}{l}\text { NA } \\
- \\
-\end{array}$ & $\begin{array}{l}- \\
- \\
-\end{array}$ & $\begin{array}{l}- \\
- \\
-\end{array}$ & $\begin{array}{l}- \\
- \\
-\end{array}$ \\
\hline $\begin{array}{l}\text { Environmental Topics } \\
\text { Regulatory lssues } \\
\text { Emissions }\end{array}$ & $\begin{array}{l}\text { NA } \\
\text { NA }\end{array}$ & $\begin{array}{c}\text { NA } \\
\text { Page Xv }\end{array}$ & $\begin{array}{c}\text { NA } \\
\text { Page Xv }\end{array}$ & $\begin{array}{c}\text { NA } \\
\text { Page xv }\end{array}$ & $\begin{array}{c}\text { NA } \\
\text { Page Xv }\end{array}$ & $\begin{array}{c}\text { NA } \\
\text { Page Xv }\end{array}$ & $\begin{array}{c}\text { NA } \\
\text { Page } 91\end{array}$ & $\begin{array}{l}\text { NA } \\
\text { NA }\end{array}$ & $\begin{array}{l}\text { Page } 34 \\
\text { Page } 69\end{array}$ & $\begin{array}{l}\text { Page } 35 \\
\text { Page 69 }\end{array}$ \\
\hline
\end{tabular}

'Includes liquefied natural gas. - = Not applicable.

NA = Not available in this report. 


\section{Limitations}

This report does not discuss geographic distributions of: (1) alternative fueled vehicles or (2) consumption of alternative and replacement fuels. Also, emissions information contained in this report primarily covers greenhouse gases from most of the important parts of the fuel cycle. Discussion of emissions should not be considered complete and may be further augmented in subsequent reports. A subsequent report, which will respond more specifically to Section 503(a) of the Energy Policy Act, will require that EIA estimata for the 1994 calendar year:

- Numbers of each type of alternative fueled vehicle likely to be in the United States

- Probable geographic distribution of such vehicles

- Quantity consumed and distribution of each type of replacement fuel

- Greenhouse gas emissions likely to result from replacement fuel use.

\section{Data Sources}

Information in this report is collected largely from secondary sources, as EIA currently collects limited alternative fuel data. The remaining information is from government (Federal, State, and local) sources, industry, and academia.

Federal Government sources include: the Department of Energy, the Environmental Protection Agency, the Department of Transportation, the General Services
Administration, the Congressional Research Service, and the Office of Technology Assessment.

The principal State government source is the California Air Resources Board. Industrial sources include fuelspecific organizations, such as the American Gas Association and the American Petroleum Institute. Data were also provided by the vehicle manufacturing industry, particularly the Chrysler Corporation, Ford Motor Company, and General Motors Corporation. Other sources of information include conference papers and speeches and academia-based studies by groups such as the Society of Automotive Engineers and the 1993 National Alternative Fuels Conference.

\section{Caveats}

Because ATFs are new and diverse, the industry supporting them is highly fragmented. Comprehensive fuel-cycle data are accordingly often difficult to find and obtain. In some cases, items of interest, such as fuel economy, may not have been measured ciue to technical difficulties. Furthermore, the secondary nature of the data has prevented EIA, in some cases, from ensuring against bias in the estimates.

Consequently, the approach of EIA has been to consult widely with Federal, State, and local agencies and the private sector to assemble the most reliable estimates possible. However, not all information presented is based on survey data or complete population analyses (see Appendix B). The reader should, therefore, make allowances in applying the data due to these limitations. 


\section{Status of Alternative Fueled Vehicles}

This chapter discusses the current inventory of, and year-ahead outlook for, AFVs. First, a brief overview is presented. Second is a discussion of AFV use in fleets. The third section discusses government programs for AFVs. The chapter concludes with a detailed inventory of AFVs in 1992 and an outlook for 1994.

AFVs are currently a small fraction of the total U.S. vehicle stock. Of the 180 million $^{34}$ "light-duty" vehicles ${ }^{35}$ registered in 1992, 250,000 were AFVs. ${ }^{36}$ Two primary reasons for this are the higher cost of producing/converting AFVs and the lack of infrastructure. The market for AFVs, even on a trial basis, is limited to fleets where centralized refueling (centrally located and high-volume refueling) is performed. The preponderance of AFV fleet vehicles, most of which are LPG vehicles, are in the private sector. The presence of AFVs within the government sector, while small overall, is expected to increase dramatically in the next few years at the Federal, State, and local levels.

The Federal Government, which is a smaller market than private fleets, is attempting to overcome obstacles to AFVs by, among other things, placing them in the Federal fleet and coordinating efforts with those of State, local, and private entities to permit the development of a self-sustaining alternative fuel infrastructure.

\section{Fleet Programs}

Current ownership of AFVs is almost completely confined to fleets. ${ }^{37}$ This is expected to continue for the foreseeable future. About 6 percent (11 million ${ }^{38}$ ) of all vehicles (including AFVs) belong to fleets.

Unlike privately owned vehicles, fleet vehicles generally operate in highly structured and restricted situations, such as certain geographic areas or cargo-carrying loads. Therefore, cargo-carrying capacity is an im-ortant issue for fleets. Conversely, fleets seldom have requirements to carry four or more passengers or to go without refueling overnight, as contrasted with privately owned vehicles. These and other factors affect a vehicle's operational ("duty cycle") requirements.

Although individual fleet operations are highly restricted, compared with privately owned vehicles, fleets as a whole have a diverse set of routes and duty cycles. Therefore, it is critical that AFV characteristics match fleet requirements. Almost any current AFV technology can serve short-range (less than 60 miles) duty cycles, while ethanol, methanol, and LPG are currently the only potential alternative transportation fuels for long duty cycles (over 200 miles). Because of current fuel capacity limitations, CNG vehicles now provide a range of just under 200 miles per day. Current "demonstration-program" AFVs operated by a variety of fleet owners have shorter travel ranges than traditionally fueled vehicles. As a consequence, information from these programs will be most useful for shorter range applications.

Currently, businesses more than any other ownership category-over 44 percent $^{39}$ (Figure 1)-use fleet vehicles. They also account for most LPG vehicles. Leased vehicles (individual leased plus daily rental) account for 35 percent of fleet vehicles, with little AFV penetration expected. Utilities and the Government represent 10 percent and 7 percent of total fleet vehicles, respectively. However, Federal ownership of AFVs is set to rise due to the EPACT Federal AFV purchase requirements and the goals of Executive Order 12844.

\footnotetext{
34Obtained from R.L. Polk and Company, Detroit, MI.

${ }^{35} \mathrm{~A}$ vehicle with a gross weight of 8,500 pounds or less.

${ }^{36}$ The data sources for Federal and non-Federal AFVs are not comparable. Therefore, this estimate should be regarded as only a rough approximation. About 2,250 AFVs were operated within the Federal Government in 1992.

${ }^{37}$ EPACT defines a fleet as a group of 20 or more vehicles; however, current data are available only for fleets of 10 or more vehicles, corresponding to the CAAA definition of a fleet.

${ }^{36}$ Data are for fleets with a minimum of 10 vehicles. Automotive Fleet Research Department, Automotive Fleet 1993 Fact Book (Redondo Beach, CA: Bobit Publishing Company, 1993), p. 24. General Services Administration, Federal Motor Vehicle Fleet Report (Washington, DC).

${ }^{39}$ Automotive Fleet Research Department, Automotive Fleet 1993 Fact Book (Redondo Beach, CA: Bobit Publishing Company, 1993 ), p. 16.
} 
Figure 1. Distribution of Light-Duty Vehicle Fleets by Use, 1992

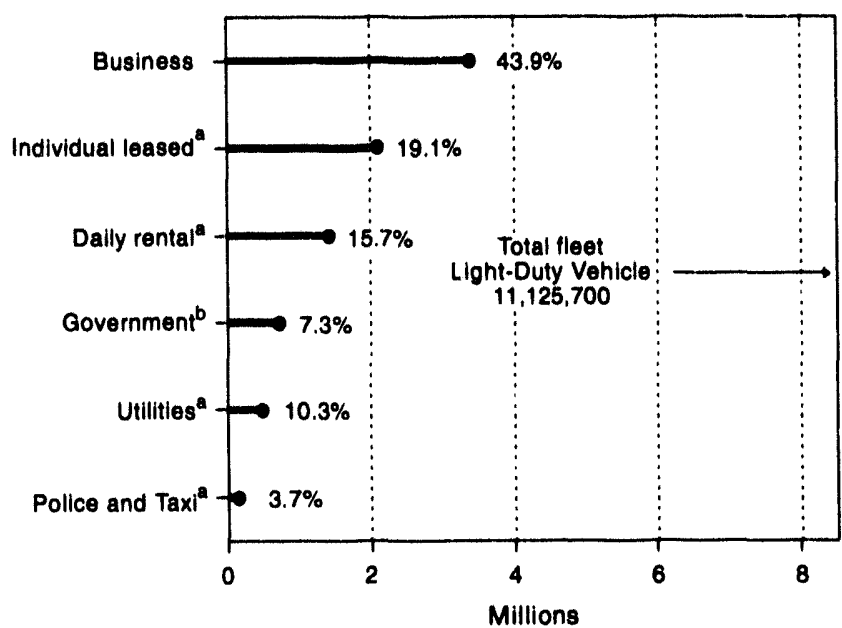

Individual leased, daily rental, utility, and police/taxi fleets are not included in the business category.

'Government consists of Federal, State, and local (excluding law enforcement) jurisdictions. While other sources indicate higher vehicle counts, the proportions represented here are probably reflective of reality.

Note: Data include business fleets with 10 or more vehicles and all individually leased automobiles.

Sources: Automotive Fleet Research Department, Automotive Fleet 1993 Fact Book (Redondo Beach, CA: Bobit Publishing Company, 1993), and General Services Administration, Federal Motor Vehicle Fleet Report.

\section{Federal Fleet Programs}

In order to meet AFV acquisition goals established in Executive Order 12759, the DOE initiated and implemented a 5-year planning process for each Federal agency's AFV purchases. Title III of EPACT and Executive Order 12844 provide further support for Federal Government AFV purchase plans (see Table 20 in Chapter 5). To enable the General Services Administration (GSA) and the DOE to assist other Federal agencies in matching available vehicles with requirements, as well as to establish information on AFV location and type of infrastructure required, ${ }^{40}$ the plans must include: acquisitions by purchase year, AFV type, fuel requirement, and geographic location of the vehicles. The compiled data are provided to GSA, original equipment manufacturers, and replacement/alternative fuel suppliers.

Each year, turnover and new requirements result in the Federal Government purchasing around 50,000 light- duty vehicles. ${ }^{41}$ As of 1992, the Federal Government fleet had between 550,000 and 565,000 vehicles. ${ }^{42}$ About 25 percent were leased through GSA's Interagency Fleet Management System. The rest were either purchased by Federal agencies directly or through GSA's Automotive Commodity Center. The vehicles purchased through the Automotive Commodity Center prior to 1993 were from original equipment manufacturers (OEMs) that produce dedicated, flexible-fueled, dualfueled, ${ }^{43}$ or bi-fueled vehicles. (See the Glossary for an explanation of vehicle types.)

GSA disseminates AFV information to State and local governments through regional meetings each year. Additionally, DOE assists State and local agencies through its Regional Support Office program. This program which provides support to State and local working groups which developed a voluntary 5-year AFV acquisition plan. The coordination of Federal, State, and local planning for vehicle purchases adds incentives for original equipment manufacturers and fuel suppliers to produce AFVs and ATFs, by decreasing the uncertainties that surround the introduction of any new technology.

To further stimulate market penetration of AFVs, DOE has implemented a Clean Cities Program. The program was designed to merge diverse elements of society to establish a self-sustaining environment for the use of AFVs. Participants in the program include Federal, State, and local governments, fuel suppliers, vehicle manufacturers, consumers, fleet managers, utilities, environmental groups, and others.

\section{State Programs}

As mentioned earlier, geographic detail regarding AFV counts and ATF consumption is not provided in this report. The highly disaggregated nature of the alternative fuel industry, combined with the fledgling nature of State AFV programs, makes obtaining comprehensive data on State programs a lengthy process. Certain States, however, are taking well-publicized actions in the AFV arena to combat air pollution (see Appendix A). Among these States are California, Texas, and New York. California, which has the most severe air quality problem, also has the most comprehensive State ATF/ AFV program. Since California has 12 percent of the Nation's total motor vehicle population, its programs can have a major impact on the AFV/ATF situation in the United States.

${ }^{40}$ The Department of Energy works under the Alternative Motor Fuels Act of 1988 reimbursement program to pay the differential cost of AFVs. This program was expanded by EPACT.

${ }^{41}$ Some vehicles (such as tactical ones that are purchased by the appropriate agencies in the U.S. Department of Defense or service vehicles for the U.S. Postal Service) are not included.

${ }^{42}$ This discussion includes only light-duty, "nontactical" vehicles.

${ }^{43}$ Generally, the U.S. Postal Service and the Department of Defense retrofit or convert only vehicles that are dual-fueled. 


\section{Inventory}

In 1992, about 221,000 AFVs were fueled by LPG (Table 2). CNG was the next largest AFV type, with about 24,000 vehicles in 1992. A large number of CNG vehicles are used by utilities; some are for demonstration while others do not have the same duty cycle as comparable, conventionally fueled vehicles. Methanol ("M-85") vehicles comprise the third-largest category of AFVs with nearly 2,800 vehicles. Electric vehicles are fourth, but many of these do not operate under normal duty-cycle conditions.

Berause the AFV portion of the Federal fleet is expected to undergo rapid growth in the next few years, a detailed discussion of Federal AFVs follows.

\section{Federal Alternative Fueled Vehicles}

As of the end of December 1992, there were approximately 2,240 Federal AFVs. ${ }^{44}$ Nearly 90 percent were fueled by CNG, with the remainder fueled by mixtures of methanol and gasoline (M-85), ethanol and gasoline (E-85), or LPG. ${ }^{45}$ By August 31, 1993, Federal AFVs numbered approximately 7,600 , with more than 5,300 M-85 vehicles ( 71 percent of the total Federal AFV fleet) (Table 3). There were also about 2,100 CNG vehicles and fewer than 100 vehicles using E-85.

While Executive Order 12844 targets 11,250 AFVs as replacement vehicles in 1994, estimated purchases for AFVs are only 10,800 vehicles. ${ }^{46}$ Nonetheless, this will increase the AFV Federal fleet nearly fivefold from the

Table 2. Estimated Number of Alternative Fueled Vehicles by Ownership Class, 1992

\begin{tabular}{|c|c|c|c|}
\hline \multirow[b]{2}{*}{ Fuel } & \multicolumn{3}{|c|}{ Ownershlp Class } \\
\hline & Federal Government' & State/Local Government & Private \\
\hline$\ldots \ldots \ldots \ldots \ldots$ & 20 & $>11,000$ & $>209,500$ \\
\hline$\ldots \ldots \ldots \ldots \ldots$ & 1,978 & 4,700 & 17,800 \\
\hline$M-85^{3}$ & 220 & 2,521 & 27 \\
\hline$E-85^{4} \ldots \ldots \ldots \ldots \ldots$ & 22 & 118 & 29 \\
\hline Electricity $\ldots \ldots \ldots \ldots \ldots$ & -- & 101 & 1,589 \\
\hline$M-100^{5} \ldots$ & -- & 398 & 6 \\
\hline$E-95^{6} \ldots$ & -- & 25 & 13 \\
\hline LNG $\ldots \ldots \ldots \ldots \ldots$ & -. & 71 & 19 \\
\hline Biodiesel $^{7} \ldots \ldots \ldots \ldots$ & -- & -- & -- \\
\hline Total $\ldots \ldots \ldots \ldots \ldots$ & 2,240 & $>18,934$ & $>228,983$ \\
\hline
\end{tabular}

'Data from the General Services Administration agencies (Interagency Fleet Management System and Automotive Commodity Center) plus the Federal agencies' own vehicles that were retrofitted during the year are included. Data are based on actual vehicle counts in place as of year-end 1992.

${ }^{2}$ The actual number of vehicles for State and local governments and for the private sector may be as much as 50 percent greater. The estimates reported indicated a lower limit.

${ }^{3} \mathrm{~A}$ fuel mixture of 85 percent methanol and 15 percent gasoline.

${ }^{4} \mathrm{~A}$ fuel mixture of 85 percent ethanol and 15 percent gasoline.

${ }^{5} \mathrm{~A}$ fuel consisting of 100 percent methanol.

${ }^{8} \mathrm{~A}$ fuel mixture of 95 percent ethanol and 5 percent gasoline.

${ }^{7}$ A diesel-fuel substitute made from vegetable oils (methyl ester) or animal tallow (methyl tallowate).

Notes: Fuel terms are defined in the Glossary. LPG, liquefied petroleum gas (propane); CNG, compressed natural gas; LNG, liquefied natural gas. Data conform with information compiled by the Alternative Fuel Data Center at the National Renewable Energy Laboratory.

Sources: Federal: General Services Administration (Interagency Fleet Management System and Automotive Commodity Center) and Federal agencies. Staten_ocal Government and Private: Science Applications International Corporation, Alternative Transportation Fuels and Vehicles Data Development, April 11, 1994, Task No. 93-112, Contract Number DE-AC01-92EI21948.

\footnotetext{
${ }^{4}$ This value represents the number of AFVs leased through the Interagency Fleet Management System, purchased through the Automotive Commodity Center, and after-market conversions. The majority of these vehicles are light duty.

${ }^{45}$ Although the General Services Administration does not currently purchase LPG vehicles from the original equipment manufacturers, some converted LPG vehicles are in the Federal fleet.

${ }^{46}$ These data were obtained through the U.S. Department of Energy, Office of Alternative Fuels. As of the report date, this is the planned acquisition total. Because of the uncertainty regarding CNG vehicles, estimates may change.
} 
Table 3. Actual and Eetimated Numbers of Alternative Fueled Vehicles in the Federal Fleet, 1992-1994

\begin{tabular}{|c|c|c|c|}
\hline \multirow[b]{2}{*}{ Fual } & \multicolumn{2}{|c|}{ Actual Inventorles' } & \multirow{2}{*}{$\begin{array}{l}\text { Eotimated Purchaces } \\
1994^{4}\end{array}$} \\
\hline & $1992^{2}$ & $1893^{3}$ & \\
\hline LPG $\ldots \ldots \ldots \ldots \ldots \ldots \ldots$ & 20 & 20 & 150 \\
\hline CNG $\ldots \ldots \ldots \ldots \ldots \ldots$ & 1,978 & 2,137 & 7,000 \\
\hline$M-85^{5} \ldots \ldots \ldots \ldots \ldots \ldots$ & 220 & 5,363 & 3,640 \\
\hline$E-85^{\circ} \ldots \ldots \ldots \ldots \ldots$ & 22 & 79 & - \\
\hline Electricity . . . . . . . . . . & - & 7 & 10 \\
\hline$M-100^{7} \ldots \ldots \ldots \ldots \ldots$ & - & -- & - \\
\hline$E-95^{\circ} \ldots \ldots \ldots \ldots \ldots \ldots$ & -. & -- & - \\
\hline LNG $\ldots \ldots \ldots \ldots \ldots \ldots \ldots$ & -- & -- & - \\
\hline Blodlesel $\ldots \ldots \ldots \ldots \ldots \ldots$ & - & -- & - \\
\hline Total $\ldots \ldots \ldots \ldots \ldots \ldots \ldots$ & 2,240 & 7,608 & 10,800 \\
\hline
\end{tabular}

'Data from the General Services Administration agencies (Interagency Fleet Management System and Automotive Commodity Center) plus the Federal agencies' own vehicles that were retrofitted during the year.

${ }^{2}$ Data for 1992 are based on actual vehicle counts in place as of year-end 1992.

${ }^{3}$ Data for 1993 are generally based on vehicles in place as of August 31, 1993. Some vehicles retrofitted in November 1993 are also included in the count.

'Data for 1994 are based on estimated requested vehicles. As of the report date, these are the plans for 1994 acquisitions. Because of the uncertainty of CNG vehicles, estimates may change.

${ }^{B} A$ fuel mixture of 85 percent methanol and 15 percent gasoline.

'A fuel mixture of 85 percent ethanol and 15 percent gasoline.

${ }^{7} A$ fuel consisting of 100 percent methanol.

A fuel mixture of 95 percent ethanol and 5 percent gasoline.

${ }^{9} \mathrm{~A}$ diesel-fuel substitute made from vegetable oils (methyl ester) or animal tallow (methyl tallowate).

Note: Fuel terms are defined in the Glossary.

Sources: Actual Inventorles: General Services Administration (Interagency Fleet Management System and Automotive Commodity Center) and other Federal agencies. Eetimated Purchases: U.S. Department of Energy, Office of Alternative Fuels.

1992 level. The vehicles will be leased through the GSA Interagency Fleet Management Program, purchased from the Automotive Commodity Center, or retrofitted through private conversion companies. Nearly one-third $(3,640)$ will be fueled by methanol. One reason is that the original equipment manufacturers are charging a lower incremental cost for a methanol-fueled vehicle. Demand in the Federal fleets is also high for new vehicles operating on CNG $(7,000)$, although there is a higher incremental purchase cost for these vehicles. The remainder of the known plan for 1994 includes the purchase of about 150 LPG-fueled vehicles and 10 electric vehicles.

\section{Non-Federal Alternative Fueled Vehicles}

The estimated number of AFVs outside the Federal sector ${ }^{47}$ was about 248,000 at the end of $1992^{48}$ and is expected to reach 293,000 in 1994 (Table 4). In 1992, more than 80 percent were light-duty vehicles; most operated on LPG and belonged to the private sector (Table 5). The 1994 estimates indicate that these trends will continue.

A minimum of 221,000 LPG-fueled vehicles was established for 1992, based on a combination of Stateby-State enumeration, estimation, and imputation. The enumeration was made using the official State registrations in the 11 States requiring owners of on-road LPGfueled vehicles to register and identify the fuel. Another 6 States require the AFV designation but do not distinguish LPG-fueled vehicles from other AFVs. For these States, the LPG-fueled vehicle count was estimated by subtracting the counts for CNG, LNG, and alcohol-fueled vehicles from AFV total registrations. For the remaining 33 States, where registration data do not permit direct or indirect enumeration, an estimate was derived based on an imputation from the original 17

\footnotetext{
${ }^{47}$ Includes State and local government, private fleet, and nonprivate fleet data.

"Science Applications International Corporation, Alternative Transportation Fuels and Vehicles Data Development, April 11, 1994, Task No. 93-112, Contract Number DE-AC01-92EI21948.
} 
Table 4. Estimated Number of Non-Federal Afternative Fueled Vehicles by Welght Class, 1992 and 1994

\begin{tabular}{|c|c|c|c|c|c|c|}
\hline \multirow[b]{2}{*}{ Fuel } & \multicolumn{3}{|c|}{1992} & \multicolumn{3}{|c|}{$1994^{1}$} \\
\hline & Total & $\begin{array}{l}\text { Light-Duty } \\
\text { Vehiclos }\end{array}$ & $\begin{array}{l}\text { Heavy-Duty } \\
\text { Vehicles }\end{array}$ & Total & $\begin{array}{l}\text { Light-Duty } \\
\text { Vohicles }\end{array}$ & $\begin{array}{l}\text { Heavy-Duty } \\
\text { Vehicles }\end{array}$ \\
\hline$\angle P G^{2}$ & $>220,500$ & $>177,000$ & $>43,500$ & $>231,500$ & $>186,000$ & $>45,500$ \\
\hline CNG & 22,500 & 20,200 & 2,300 & 47,900 & 42,600 & 5,300 \\
\hline$M-85^{3}$ & 2,548 & 2,414 & 134 & 8,684 & 8,432 & 252 \\
\hline$E-85^{4}$ & 147 & 145 & 2 & 399 & 397 & 2 \\
\hline$M-100^{5}$ & 404 & 37 & 367 & 712 & 37 & 675 \\
\hline$E-95^{6} \ldots$ & 38 & 10 & 28 & 57 & 11 & 46 \\
\hline LNG . . & 90 & 5 & 85 & 525 & 5 & 520 \\
\hline Electricity ......... & 1,690 & 1,680 & 10 & 2,824 & 2,779 & 45 \\
\hline Tctal .......... & $>247,917$ & $>201,491$ & $>46,426$ & $>292,601$ & $>240,261$ & $>52,340$ \\
\hline
\end{tabular}

'Estimates were obtained from various sources by fuel type. See Appendix B, Table B1, for more information on these sources.

${ }^{2}$ The actual number of vehicles may be as much as 50 percent greater. The estimated reported indicates a lower limit.

${ }^{3} \mathrm{~A}$ fuel mixture of 85 percent methanol and 15 percent gasoline.

4A fuel mixture of 85 percent ethanol and 15 percent gasoline.

${ }^{5} \mathrm{~A}$ fuel consisting of 100 percent methanol.

${ }^{\circ} \mathrm{A}$ fuel mixture of 95 percent ethanol and 5 percent gasoline.

Note: Fuel terms are defined in the Glossary.

Source: Science Applications International Corporation, Alternative Transportation Fuels and Vehicles Data Development, April 11, 1994, Task No. 93-112, Contract Number DE-AC01-92EI21948.

States of fuel consumed per vehicle, as adjusted for AFVs other than LPG AFVs in 6 States. ${ }^{49}$

Members of the LPG-fueled vehicle industry estimate that the number of these vehicles should increase over the next few years because of various State and Federal clean air requirements. Based on an increase in the LPG vehicle stock of perhaps 2 percent fer year and a slight boost from clean air requirements, on-road vehicles operating on LPG are expected to reach at least 232,000 by the end of $1994 .^{50}$

Data obtained from direct and indirect suppliers ${ }^{51}$ of natural gas for CNG-fueled vehicles across the country $^{52}$ indicate that there were approximately 22,500 non-Federal on-road vehicles as of December 31, 1992. This is expected to climb to nearly 48,000 by December 1994 because of an expansion of AFVs in utility and other private fleets. In contrast, the count for on-road LNG-fueled vehicles was much lower, at 90 in 1992. Only 525 LNG vehicles are expected by the end of 1994.
During 1992, there were about 2,500 M-85 on-road vehicles, based on data obtained from private contacts and agencies within State and local governments (see Appendix C). Virtually all methanol-fueled vehicles in service used M-85, and most were purchased through a California State program. Methanol vehicle programs are part of California's large-scale effort to demonstrate and introduce AFVs. Outside California, governments own virtually all other methanol-fueled vehicles. The 1994 estimate of nearly 8,700 more than triples the 1992 count for non-Federal on-road vehicles. Approximately 95 percent of these will operate in California. Nearly 640 of those California vehicles will use M-100-630 of which will be State or municipally owned transit buses.

Most E-85 vehicles are used in small local and State government demonstration programs or agricultureassociation demonstration fleets. There were nearly 150 E-85 vehicles in the United States by the end of 1992, based on contacts from various non-Federal governmental jurisdictions, agricultural associations, alternative fuel programs, and fleet managers. Because of

\footnotetext{
${ }^{4}$ See Appendix B for methodology.

${ }^{50}$ Science Applications International Corp sration, Alternative Transportation Fuels and Vehicles Data Development, April 11, 1994, Task No. 93-112, Contract Number DE-AC01-92.ED.1948.

${ }^{51}$ Direct suppliers sell natural gas in ?. compressed state, whereas indirect suppliers sell to retailers who can compress it.

${ }^{52}$ The vehicle count is made in the 5 cate where the utility supplying the CNG is located, not according to the State in which the fleet operates. Some skewing of data will sccur when a utility serves a multi-State region. On a regional basis, counts will be subject to less uncertainty.
} 
Table 5. Estimated Number of Non-Federal Aiternative Fueled Vehicles by Ownershlp and Welght Class, 1992 and 1994

\begin{tabular}{|c|c|c|c|c|c|c|}
\hline \multirow[b]{2}{*}{ Fuel } & \multicolumn{2}{|c|}{ Total } & \multicolumn{2}{|c|}{ State and Local Government } & \multicolumn{2}{|c|}{ Private } \\
\hline & $\begin{array}{l}\text { Llght-Duty } \\
\text { Vehiclos }\end{array}$ & $\begin{array}{c}\text { Heavy-Duty } \\
\text { Vohicles }\end{array}$ & $\begin{array}{c}\text { Light-Duty } \\
\text { Vehicles }\end{array}$ & $\begin{array}{c}\text { Heavy-Duty } \\
\text { Vehicles }\end{array}$ & $\begin{array}{l}\text { Llght-Duty } \\
\text { Vehicles }\end{array}$ & $\begin{array}{c}\text { Heavy-Duty } \\
\text { Vehicles }\end{array}$ \\
\hline \multicolumn{7}{|c|}{$1992^{1}$} \\
\hline$\ldots \ldots \ldots \ldots$ & $>177,000$ & $>43,500$ & 9,400 & 1,600 & $>167,600$ & $>41,900$ \\
\hline CNG $\ldots \ldots \ldots \ldots$ & 20,200 & 2,300 & 3,700 & 1,000 & 16,500 & 1,300 \\
\hline $\mathbf{M}-85^{3} \ldots \ldots \ldots \ldots$ & 2,414 & 134 & 2,390 & 131 & 24 & 3 \\
\hline$E-85^{4} \ldots \ldots \ldots \ldots$ & 145 & 2 & 117 & 1 & 28 & 1 \\
\hline Electricity ......... & 1,680 & 10 & 92 & 9 & 1,588 & 1 \\
\hline$M-100^{5} \ldots \ldots \ldots$ & 37 & 367 & 37 & 361 & 0 & 6 \\
\hline$E-95^{8}$ & 10 & 28 & 1 & 24 & 9 & 4 \\
\hline LNG . . . . . . . & 5 & 85 & 2 & 69 & 3 & 16 \\
\hline Total .......... & $>201,491$ & $>46,426$ & $>15,739$ & $>3,195$ & $>185,752$ & $>43,231$ \\
\hline \multicolumn{7}{|c|}{$1994^{1}$} \\
\hline$\ldots \ldots \ldots$ & $>186,000$ & $>45,500$ & $>10,000$ & $>1,500$ & $>176,000$ & $>44,000$ \\
\hline CNG & 42,600 & 5,300 & 12,700 & 2,800 & 29,900 & 2,500 \\
\hline$M-85^{3}$ & 8,432 & 252 & 8,378 & 252 & 54 & 0 \\
\hline$E-85^{4} \ldots$ & 397 & 2 & 338 & 1 & 59 & 1 \\
\hline Electricity & 2,779 & 45 & 207 & 44 & 2,572 & 1 \\
\hline$M-100^{5} \ldots$ & 37 & 675 & 37 & 669 & 0 & 6 \\
\hline $\mathrm{E}-95^{6} \ldots \ldots \ldots \ldots$ & 11 & 46 & 1 & 42 & 10 & 4 \\
\hline LNG $\ldots \ldots \ldots \ldots$ & 5 & 520 & 2 & 498 & 3 & 22 \\
\hline Total $\ldots . \ldots \ldots$ & $>240,261$ & $>52,340$ & $>31,663$ & $>5,806$ & $>208,598$ & $>46,534$ \\
\hline
\end{tabular}

${ }^{1}$ Estimates were obtained from various sources by fuel type. See Appendix B, Table B1, for more information on sources.

${ }^{2}$ The actual number of vehicles may be as much as 50 percent greater. The estimates reported indicate a lower limit.

${ }^{3} \mathrm{~A}$ fuel mixture of 85 percent methanol and 15 percent gasoline.

${ }^{4} A$ fuel mixture of 85 percent ethanol and 15 percent gasoline.

${ }^{5} \mathrm{~A}$ fuel consisting of 100 percent methanol.

${ }^{6} \mathrm{~A}$ fuel mixture of 95 percent ethanol and 5 percent gasoline.

Note: Fuel terms are defined in the Glossary.

Source: Science Applications International Corporation, Alternative Transportation Fuels and Vehicles Data Development, April 11, 1994, Task No. 93-112, Contract Number DE-AC01-92EI21948.

expanded AFVs in demonstration programs, the yearend 1994 estimate is projected at more than 2.5 times the 1992 count (almost 400) of E-85 on-road vehicles. There were significantly fewer E-95 vehicles. The 1992 count and 1994 estimate of E-95 vehicles are 38 and 57, respectively.

Electric vehicles in the United States are almost exclusively light-duty vehicles consisting of three basic types: original-design, after-market conversion, ${ }^{53}$ and hobbyist-built vehicles. Each serves a different purpose. Only a few existing vehicles are of the type likely to be placed in service after 1998, when California law requires a certain number of "zero-emission vehicles" to be sold. As of 1992, fewer than 1,700 non-Federal onroad electric vehicles existed in the country. By yearend 1994, the estimate is expected to rise to approximately 2,800 . About 200 to 300 of the 1992 vehicles came from original equipment manufacturers, with most of them in experimental or demonstration use by utilities and manufacturers. Manufacturers believe there may be 400 to 600 OEM vehicles by the end of 1994 .

\footnotetext{
${ }^{53} \mathrm{~A}$ standard, conventional fueled, factory-produced vehicle to which equipment has been added that enables the vehicle to operate on an alternative fuel.
} 


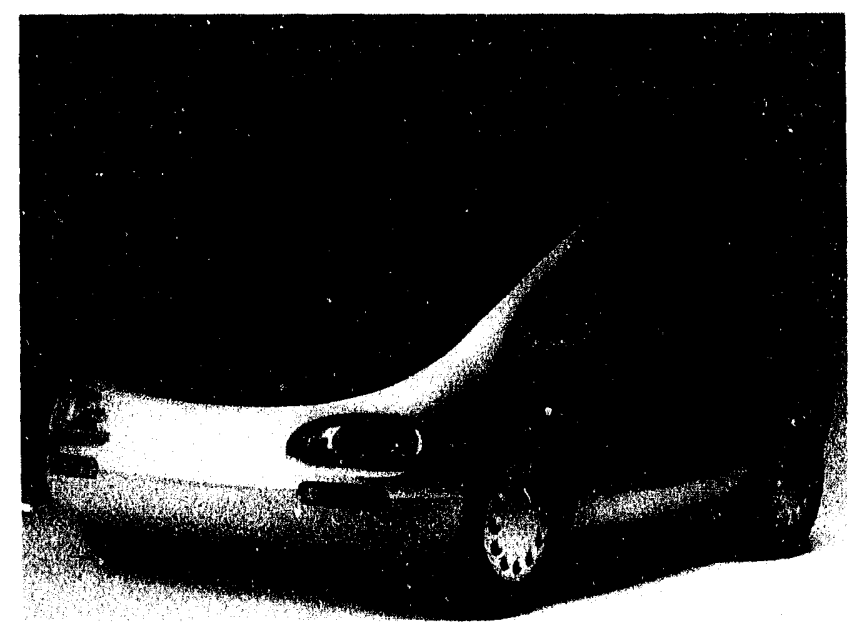

A modern electric vehicle.
In addition to the electric vehicles produced by manufacturers, an estimated 500 to 800 vehicles propelled by electricity have been produced as after-market conversions. Through the end of 1994, this count is estimated to increase by 200 to 300 vehicles. The converted electric vehicles are generally built on a new chassis produced from the conventional manufacturers with principal modifications designed to accommodate the electric motor and the battery pack. These modifications are commonly less extensive than design changes made by the original equipment manufacturer. Many converted electric vehicles are being used by utilities and some early experimenters who adapted conventional vehicles. The count of vehicles operating on electricity in the latter category-hobbyist vehicles-was estimated in 1992 at 700 to $1,300 .{ }^{54}$ Many of these vehicles are kitmodified conversions of new and used conventional vehicles. 


\section{Fuel Consumption}

Today's consumption of alternative fuels is small compared with the total transportation market for gasoline and diesel. LPG, M-85, and CNG were the only alternative fuels consumed in significant quantities during 1992, exceeding 500,000 gasoline-equivalent gallons (Table 6). Methyl tertiary-butyl ether (MTBE) and ethanol were both used as replacement fuels, and represented significant volumes of fuel consumed. MTBE, an ether, was used both as an octane-enhancing agent and as an oxygenate in gasoline ${ }^{55}$ to meet oxygenated gasoline requirements as mandated by the Clean Air Act Amendments of 1990. Ethanol was used as a gasoline extender in gasohol as well as an oxygenate also to meet oxygenated gasoline requirements. While oxygenates other than MTBE and ethanol can satisfy oxygenated gasoline requirements, they were not used in any significant volumes. The DOE collects data for gasoline, diesel, MTBE, ethanol, and transportation use of natural gas, but consumption values for the remaining fuels were estimated or derived from other sources of data.

Methanol, LPG, natural gas, and electricity are being produced today for markets other than transportation. If use for transportation becomes economically attractive, the transportation market could be one of their most profitable end uses.

\section{Alternative Fuels}

\section{Methanol Consumption}

In 1991, the major uses of methanol in North America were for producing MTBE (29.3 percent), formaldehyde (28.3 percent), and acetic acid (10.9 percent) (Table 7). Methanol used in M-85 and M-100 was estimated to be 0.2 percent of demand. Large growth in MTBE in 1992 was anticipated as the United States began its first oxygenated gasoline season in the winter of 1992-93. ${ }^{56}$

Vehicles in California consumed most of the M-85 produced in 1992, while M-100 consumption was negligible. During 1992, 565,000 gallons of M-85 (322,000 gasoline-equivalent gallons) were consumed in the California retail market, with 2.41 million gallons or 1,373 million gasoline-equivalent gallons consumed in total (Table 8). The trend is upward for 1993. Through the third quarter of 1993, California retail sales were 817,000 gallons (466,000 gasoline-equivalent gallons), and total consumption reached a level of 6.3 million gallons (3.6 million gasoline-equivalent gallons). Only 13 percent of M-85 was supplied through retail outlets in 1993, with the remaining 87 percent being used by fleets. To place these volumes for methanol in perspective, total gasoline consumption for California was over 13 billion gallons in $1992 .^{57}$

\section{Ethanol Consumption}

The majority of ethanol used today is for gasohol (E-10) and for ethanol/gasoline blends lower than E-10 to meet oxygenated gasoline requirements. Very little ethanol is consumed as an alternative fuel (E-85 and E-95). Total ethanol consumed in 1992 was 1.06 billion gallons, or 0.7 billion gallons of gasoline equivalent.

In 1992, EIA began publishing ethanol production and stocks for fuel use. Total consumption can be imputed from this information. The U.S. Department of Transportation (DOT) assembles data regarding fuel ethanol consumption from the States and from the Internal Revenue Service (IRS). The DOT's published data on gasohol sales provide an indication of geographic use. Ethanol fuel consumption is estimated as 10 percent of DOT's gasohol sales prior to $1992,{ }^{58}$ distributed across four Census regions (Table 9). The largest consuming

\footnotetext{
${ }^{55}$ For further discussion on the role of MTBE as an octane-enhancing agent and as an oxygenate in gasoline, refer to Chapter 7 of this report.

${ }^{56}$ Estimate of 1991 world demand published in "Methanol, MTBE Suppliers Will Likely Keep Up with Rising Demand," Oil and Gas Journal (Tulsa, OK: PennWell Publishing, March 29, 199i), p. 48.

${ }^{57}$ Federal Highway Administration, Monthly Motor Fuels Reported by States, Table MF-33GA, as cited in National Petroleum News, Mid-June 1993, p. 103.

${ }^{58}$ Before 1993, gasohol (E-10) qualified for the Federal Motor Fuels Excise Tax Credit. However, in 1993, fuels with less than 10 percent ethanol qualified for a prorated tax credit. Since lower percentages of ethanol can meet oxygenated gasoline requirements, volumes of ethanol/gasoline mixtures were sold that contained less than 10 percent ethanol in 1993.
} 
Tabie 6. Summary of Fuel Consumption, 1992

\begin{tabular}{|c|c|c|c|c|}
\hline Fuel & Consumption & Units & Heating Value' & $\begin{array}{l}\text { Equivalont Casolino' } \\
\text { (Million Gallono) }\end{array}$ \\
\hline \multicolumn{5}{|l|}{ Traditlonal Fuels: } \\
\hline Gasoline $^{3} \ldots \ldots \ldots \ldots \ldots$ & 110,135 & Million gallons & $115,000 \mathrm{Btw} / \mathrm{gallon}$ & 110,135 \\
\hline Diesel $\ldots \ldots \ldots \ldots \ldots \ldots \ldots$ & 21,375 & Million gallons & $128,400 \mathrm{Btu} /$ gallon & 23,866 \\
\hline \multicolumn{5}{|l|}{ Alternative Fuels: } \\
\hline M-85 $\ldots \ldots \ldots \ldots \ldots \ldots \ldots$ & 2 & Million gallons & 65,530 Btu/gallon ${ }^{4}$ & 1 \\
\hline$M-100 \ldots \ldots \ldots \ldots \ldots$ & * & Million gallons & 56,800 Btu/gallon & • \\
\hline$E-85 \ldots \ldots \ldots \ldots \ldots \ldots$ & * & Million gallons & 81,800 Btu/gallon 5 & * \\
\hline$E-95 \ldots \ldots \ldots \ldots \ldots \ldots$ & * & Million gallons & 77,950 Btu/gallon 5 & * \\
\hline LPG $\ldots \ldots \ldots \ldots \ldots \ldots \ldots$ & 250 & Million gallons & 84,500 Btu/gallon & 184 \\
\hline CNG $\ldots \ldots \ldots \ldots \ldots \ldots$ & 511 & Million cubic feet & 929 Btu/cubic foot & 4 \\
\hline LNG $\ldots \ldots \ldots \ldots \ldots \ldots$ & * & & & " \\
\hline Hydrogen $\ldots \ldots \ldots \ldots \ldots \ldots \ldots$ & * & & 325 Btu/cubic foot & * \\
\hline \multicolumn{5}{|l|}{$\begin{array}{l}\text { Replacement Fuels } \\
\text { (Included In Gasoline): }\end{array}$} \\
\hline $\begin{array}{l}\text { Ethanol in E-10 and } \\
\text { Other Oxygenated Gasoline } \ldots \ldots\end{array}$ & 1,061 & Million gallons & 76,000 Btu/gallon & 701 \\
\hline MTBE $\ldots \ldots \ldots \ldots \ldots \ldots$ & 1,445 & Million gallons & 93,500 Btu/gallon & 1,175 \\
\hline
\end{tabular}

'Lower heating value. See Table 23.

${ }^{2}$ Equivalent gasoline is the quantity of fuel consumption multiplied by the fuel heating value, divided by the gasoline heating value.

${ }^{3}$ Gasoline includes the replacement fuels, ethanol and MTBE.

"Volume-weighted average of lower heating value (Btu/gallon) of gasoline and methanol.

5Volume-weighted average of lower heating value (Btu/gallon) of gasoline and ethanol.

${ }^{6}$ Represents total volumes of fuel ethanol and MTBE consumed. While some ethanol is used in off-highway vehicles (e.g., farm equipment), the majority of fuel ethanol and MTBE is used in highway vehicles.

"Value represents a negligible amount.

Notes: Fuel terms are defined in the Glossary. LPG, liquefied petroleum gas (propane); CNG, compressed natural gas; LNG, liquefied natural gas; MTBE, methyl tertiary-butyl ether; Btu, British thermal unit.

Sources: Gasoline consumption: Energy Information Administration, Petroleum Supply Annual 1992, Vol. 1, DOE/ElA-0340(92)/1 (Washington, DC, May 1993), Table S4, adjusted to include field ethanol blended and to cover only highway uses. Highway use was estimated as 97.1 percent of total gasoline supplied, based on 1990 data published in the Transportation Energy Data Book: Edition 13, prepared by Oak Ridge National Laboratory for the U.S. Department of Energy (Oak Ridge, TN, March 1993), Table 2.7. Highway diesel consumption: Energy Information Administration, Fuel Oil and Kerosene Sales 1991, DOE/EIA-0535(91), and Fuel Oil and Kerosene Sales 1992, DOE/EIA-0535(92); and Federal Highway Administration, Statistics of Highway Special Fuels Use, Table 1. M-85: California Energy Commission (facsimile provided). CNG: Energy Information Administration, Natural Gas Annual 1992, DOE/EIA-031(92) (Washington, DC, December 1992), Table 1. LPG: Estimated as 50 percent of engine fuel reported in American Petroleum Institute, 1992 Sales of Natural Gas Liquids and Liquefied Refinery Gases (Washington, DC, October 1993), which shows a total of 500 million gallons engine fuel use. (See LPG Consumption section of this chapter.) Ethanol and MTEE: Energy Information Administration, Petroleum Supply Monthly, DOE/EIA-0109(93/01) (Washington, DC, January 1993), Appendix D.

area by far is the Midwest, which is closest to the major ethanol-producing centers, followed by the South and West. Consumption of ethanol as E-85 or E-95 is not known, but must be very small because so few E-85/ E-95 vehicles are available.

\section{Liquefled Petroleum Gas Consumption}

The largest end uses of LPG are as residential and commercial fuel and chemical feedstock (Table 10).
Industrial use, which includes LPG used as refinery fuel, is also significant. Engine fuel, which includes highway transportation fuel, comprises about 3 percent of total use. Transportation use is limited.

An estimate of highway LPG use was made from the data reported for engine fuel use published by the National Propane Gas Association. This category includes off-road vehicles and stationary engines. Approximately one-half of the reported value is used to 
Table 7. Eetimated Mothanol Consumption In North America, 1991 and 1992 (Thousand Metric Tons)

\begin{tabular}{|c|c|c|c|c|}
\hline \multirow[b]{2}{*}{ Use } & \multicolumn{2}{|l|}{1891} & \multicolumn{2}{|l|}{1992} \\
\hline & Eotimated Consumption & Percent Share & Forecast Consumption & Porcent Share \\
\hline$\ldots \ldots \ldots \ldots \ldots \ldots$ & 1,617 & 29.3 & 2,090 & 34.3 \\
\hline Formaldehyde $\ldots \ldots \ldots \ldots \ldots$ & 1,561 & 28.3 & 1,580 & 25.9 \\
\hline Acetic Acid $\ldots \ldots \ldots \ldots \ldots$ & 600 & 10.9 & 600 & 9.8 \\
\hline Solvents ................. & 272 & 4.9 & 282 & 4.6 \\
\hline Methyl Methacrylate $\ldots \ldots \ldots$ & 195 & 3.5 & 195 & 3.2 \\
\hline DMT $\ldots \ldots \ldots \ldots \ldots \ldots \ldots$ & 177 & 3.2 & 177 & 2.9 \\
\hline$M-85$ and $M-100 \ldots \ldots \ldots \ldots$ & 11 & 0.2 & 17 & 0.3 \\
\hline Others $\ldots \ldots \ldots \ldots \ldots \ldots \ldots$ & 1,082 & 19.6 & 1,157 & 19.0 \\
\hline Total $\ldots \ldots \ldots \ldots \ldots \ldots$ & 5,515 & 100.0 & 6,088 & 100.0 \\
\hline
\end{tabular}

Note: DMT, dimethyl terephthalate (used in making polyester fibers).

Source: Crocco Associates, as published in "Methanol, MTBE Suppliers Will Likely Keep Up With Rising Demand," Oll and Gas Joumal (March 29, 1993), pp. 48-52.

Table 8. M-85 Consumption for Hightray Use In Callfornia, 1992 and 1993 (Thousand Gallons)

\begin{tabular}{|c|c|c|}
\hline Perlod & $\begin{array}{c}\text { Total } \\
\text { Consumption }\end{array}$ & $\begin{array}{l}\text { Retall } \\
\text { Salos } \\
\end{array}$ \\
\hline \multicolumn{3}{|c|}{1992} \\
\hline 1st Quarter .......... & 491.7 & 64.2 \\
\hline 2nd Quarter $\ldots \ldots \ldots$ & 302.0 & 100.0 \\
\hline 3rd Quarter .......... & 459.3 & 204.1 \\
\hline 4th Quarter .......... & $1,156.6$ & 196.3 \\
\hline Total .......... & $2,409.7$ & 564.6 \\
\hline \multicolumn{3}{|c|}{1993} \\
\hline 1st Quarter .......... & $1,683.8$ & 214.1 \\
\hline 2nd Quarter ... & $1,451.0$ & 273.2 \\
\hline 3rd Quarter . . . . . . . . & $3,182.2$ & 329.6 \\
\hline Total (3 Quartors) ... & $6,317.0$ & 816.9 \\
\hline
\end{tabular}

Source: California Energy Commission.

estimate highway LPG use. ${ }^{59}$ As shown in Table 10, engine fuel propane use is reported as 500 million gallons. Thus, highway use in 1992 is estimated to be 250 million gallons, or 184 million gasoline-equivalent gallons.
Table 9. Geographic Distribution of U.S. Ethanol Consumption In Gasohol Sales, Selected Years, 1980-1992

\begin{tabular}{|c|c|c|c|c|}
\hline Region & 1880 & 1885 & 1990 & 1992 \\
\hline \multicolumn{5}{|l|}{ Porcent Shares } \\
\hline Northeast & 9.4 & 0.2 & 0.0 & 0.9 \\
\hline South .... & 22.2 & 35.6 & 20.7 & 17.5 \\
\hline Midwest . & 64.6 & 57.1 & 67.1 & 68.9 \\
\hline West $\ldots \ldots \ldots \ldots \ldots$ & 3.8 & 7.1 & 12.2 & 12.7 \\
\hline Total ............. & 100.0 & 100.0 & 100.0 & 100.0 \\
\hline Total (Million Ga & 50 & 737 & 1,075 & 1,081 \\
\hline
\end{tabular}

Notes: Assumes a Lower Heating Value of 76,400 Btu per gallon. Regional definitions are provided in the Glossary.

Sources: 1980: Federal Highway Administration (FHWA), Highway Statistics, 1985 and preceding issues, Table MF33GLA. 1985 and 1990: Energy Information Administration (EIA), Estimates of U.S. Biomass Energy Consumption 1992, DOE/EIA-0548(92) (Washington, DC, May 1994), p. 6. 1992: Shares derived from FHWA, Monthly Motor Fuel Reported by States, January 1993, Table MF-33SF, except for CT, FL, IL, $I A$, and MT, which included estimates by Information Resources, Inc. (IRI) as published in FHWA, Alcohol Outlook, January 1993 through April 1993, p. 6. IRI estimates were used to fill in missing data unreported by FHWA as of the January issue. Total 1992 consumption was imputed from ethanol production and stock data in EIA, Petroleum Supply Monthly, DOE/EIA0109(93/01) (Washington, DC, January 1993), Appendix D.

\footnotetext{
59 The 50 percent is explained in "Alternative Transportation Fuels and Vehicles Data Development," Report Prepared by SAIC for the Energy Information Administration, Contract No. DE-AC01-93EI21944, Tasks 93-069 and 93-069a (Washington, DC, November 30, 1993), p. 34 .
} 
Table 10. Sales of Llquefied Petroleum Gas (Propano), by Princlpal Uses, 1984-1992 (Million Gallons)

\begin{tabular}{|c|c|c|c|c|c|c|c|c|c|}
\hline & Yoar & $\begin{array}{l}\text { Rosidentlal } \\
\text { Commerclal }\end{array}$ & Industrial' & $\begin{array}{c}\text { Englne } \\
\text { Fuel }\end{array}$ & Chomical & $\begin{array}{c}\text { Utility } \\
\text { Gas }\end{array}$ & Farm & Other ${ }^{2}$ & Total" \\
\hline 1984 & $\ldots$ & 3,887 & 1,218 & 738 & 4,861 & 168 & 995 & 1,001 & 12,867 \\
\hline $1985^{4}$ & & 4,404 & 1,122 & 735 & 5,282 & 188 & 1,156 & 687 & 13,574 \\
\hline 1986 & $\ldots \ldots \ldots \ldots$ & 4,369 & 1,218 & 654 & 4,792 & 396 & 1,132 & 230 & 12,791 \\
\hline 1987 & & 4,837 & 1,295 & 630 & 5,994 & 93 & 1,075 & 370 & 14,294 \\
\hline 1988 & & 4,807 & 1,506 & 583 & 5,831 & 190 & 1,064 & 335 & 14,316 \\
\hline 1989 & $\cdots$ & 5,389 & 1,607 & 581 & 5,581 & 103 & 1,173 & 911 & 15,344 \\
\hline 1990 & & 4,975 & 1,217 & 531 & 5,778 & 123 & 1,136 & 300 & 14,060 \\
\hline 1991 & & 5,325 & 1,218 & 542 & 6,435 & 69 & 1,134 & 324 & 15,047 \\
\hline 1992 & $\ldots \ldots \ldots$ & 5,214 & 1,846 & 500 & 6,652 & 72 & 1,363 & 222 & 15,870 \\
\hline
\end{tabular}

IIncludes refinery fuel.

${ }^{2}$ Includes secondary recovery of petroleum and synthetic natural gas (SNG) feedstock.

${ }^{3}$ American Petroleum Institute (API) data on LPG refinery inputs is used in determining LPG production and sales, in preference to volumes reported by EIA.

"Significant changes in 1985 and earlier gas sales in some States are based on additional information furnished to API by natural gas liquids pipeline companies.

Notes: Resldentlal/Commerclal: Includes propane sold for use in private households and commercial establishments such as motels, restaurants, retail stores, laundries, etc., primarily for use in space heating, water heating, and cooking. Propane used for space heating and cooking in farmhouses is reported under the "farm" category. Chemical: Includes propane sold or used internally as raw materials and solvents in the manufacture of chemicals. Also includes volumes used in the production of synthetic rubber. Sales to chemical plants for use as plant fuel are reported in the "industrial" category. Industrial: Includes propane sold to manufacturing plants for such uses as standby fuel, space heating, flame cutting, metallurgical furnaces, etc. Includes sales to petroleum refineries for fuel use and volumes consumed by reporting companies as fuel. Englne Fuel: Includes propane for use in highway vehicles (transportation), forklifts, oil field drilling and production equipment, etc. Propane used for tractors and irrigation engines and other agricultural vehicles is reported under the "farm" category. Utility Gas: Includes propane sold to gas utility companies for use as a standby fuel or for direct distribution in gas mains. Farm: Includes propane sold for use in tractors, irrigation engines, space heating of buildings (including farmhouses), cooking, crop drying, tobacco curing, flame cultivation, poultry brooding, and other agricultural applications. Other: Includes propane sold or used for any purpose not covered in the above categories, including secondary recovery use. Includes use of SNG feedstock. Sales to SNG plants for use as plant fuel is reported in the "industrial" category. Totals may not equal sum of components because of independent rounding.

Source: American Petroleum Institute, annual issues of Sales of Natural Gas Liquids and Liquefied Refinery Gases (Washington, DC), Table 4.

\section{Natural Gas Consumption}

In 1992, 17.8 trillion cubic feet of natural gas were delivered to consumers. Industrial consumers used $\mathbf{4 2 . 3}$ percent, residential 26.4 percent, utilities 15.5 percent, and commercial customers 15.8 percent. Vehicle transportation use in compressed form accounted for 511 million cubic feet in 1992, up from 367 million cubic feet in $1991 .^{60}$ Table 11 shows the consumption on a gasoline-equivalent basis. There is no significant highway vehicle consumption of LNG to date.

\section{Traditional and Replacement Fuels}

\section{Gasoline Consumption}

Gasoline supplied in the United States in 1992 was 113.4 billion gallons for the year ${ }^{61}$ (Table 12). Highway use accounted for about 97.1 percent of gasoline consumed, or about 110.1 billion gallons in 1992. Automobiles and motorcycles used approximately two-thirds of highway gasoline, with trucks consuming most of the remainder. Buses used less than 1 percent of the

${ }^{60}$ Energy Information Administration, Natural Gas Annual 1992, DOE/EIA-0131(92) (Washington, DC, November 1993 ), Table 1.

${ }^{61}$ Energy Information Administration, Petroleum Supply Monthly, (Washington, DC, December 1993), p. xvii. 
Table 11. Natural Gas Fuel Consumed In Vehicles, 1990-1992

\begin{tabular}{|c|c|c|c|}
\hline Unit of Masaure & 1890 & 1901 & 1902 \\
\hline Million Cubic Feet $\ldots \ldots \ldots \ldots \ldots$ & 270 & 367 & 511 \\
\hline Million Btu' $\ldots . .$. & 250,830 & 340,843 & 474,719 \\
\hline Gasoline-Equivalent Gallons ${ }^{2} \ldots$ & $2,181,130$ & $2,964,722$ & $4,127,991$ \\
\hline
\end{tabular}

'Natural gas is assumed to contain 929 Btu per cublc foot.

'Gasoline is assumed to contain 115,000 Btu per gallon.

Source: Energy Information Administration, Natural Gas Annual 1992, DOE/EIA-0131(92) (Washington, DC, December 1992), Table 1.

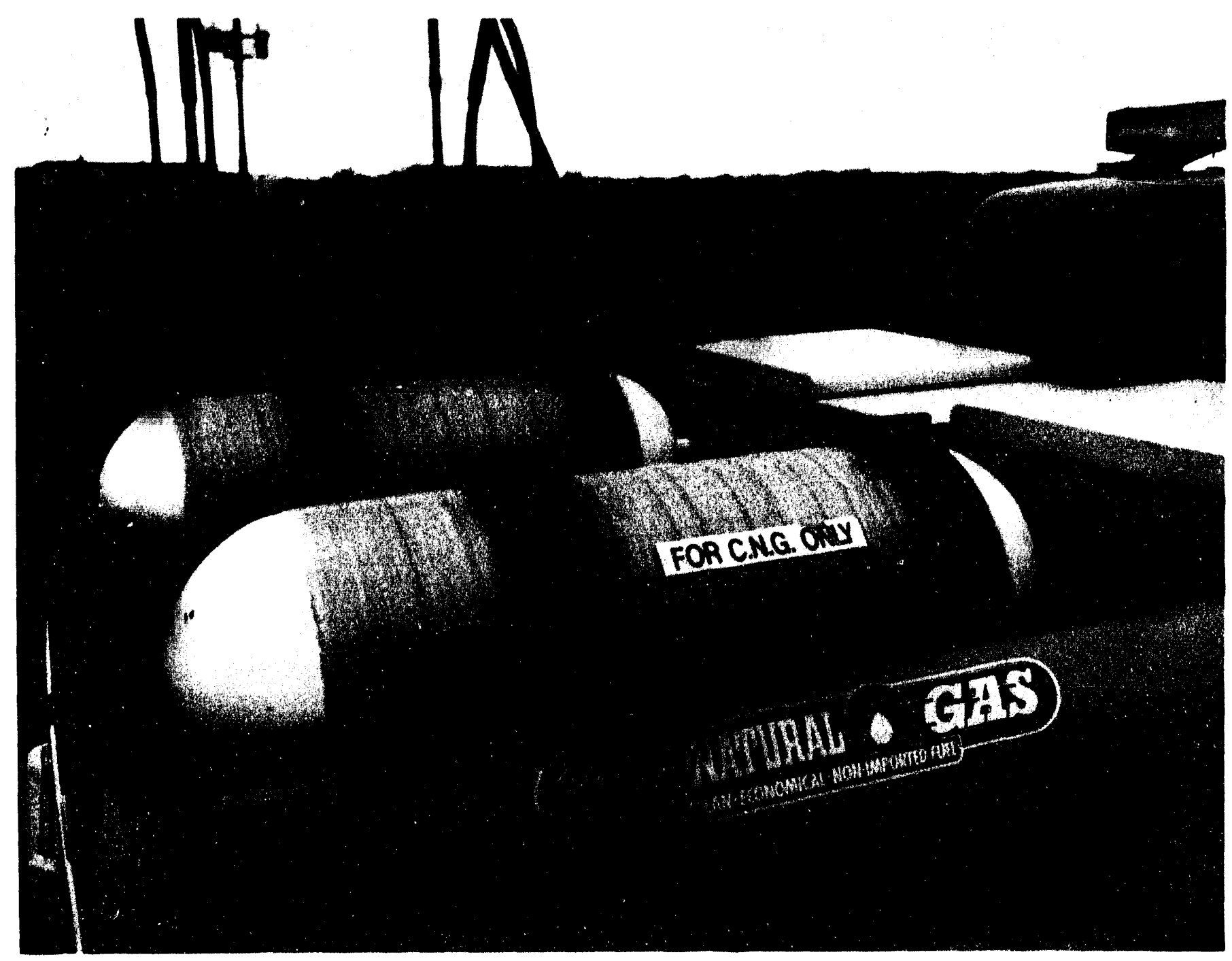

This CNG-powered pickup truck at a refueling facility shows the parallel tanks used to maintain high pressure for quick filling. 
Table 12. Total Gasoline Suppliod, 1880-1892 (Million Gallons)

\begin{tabular}{|c|c|c|}
\hline 1980 & $\ldots \ldots \ldots \ldots \ldots \ldots \ldots$ & 101,132 \\
\hline 1981 & $\ldots \ldots \ldots, \ldots, \ldots, \ldots$, & 100,994 \\
\hline 1982 & $\ldots \ldots \ldots \ldots \ldots \ldots \ldots$ & 100,243 \\
\hline 1983 & $\ldots \ldots \ldots \ldots \ldots \ldots$ & 101,515 \\
\hline 1984 & $\ldots \ldots \ldots, \ldots, \ldots \ldots$ & 102,885 \\
\hline 1985 & $\ldots \ldots \ldots \ldots, \ldots$, & 104,719 \\
\hline 1986 & $\ldots \ldots \ldots \ldots, \ldots, \cdots$ & 107,831 \\
\hline 1987 & $\ldots \ldots \ldots \ldots \ldots \ldots$ & 110,468 \\
\hline 1988 & $\ldots \ldots \ldots \ldots \ldots \ldots \ldots$ & 112,769 \\
\hline 1989 & $\ldots \ldots \ldots \ldots \ldots \ldots \ldots$ & 112,338 \\
\hline 1990 & 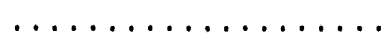 & 110,913 \\
\hline 1991 & $\ldots \ldots \ldots \ldots \ldots \ldots \ldots$ & 110,192 \\
\hline $1992^{\prime}$ & 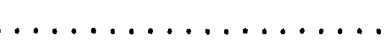 & 113,384 \\
\hline
\end{tabular}

'Of the 113.4 billion gallons supplied, approximately 110.1 billion gallons were consumed for highway use.

Note: The 1992 value has been adjusted to include fieldblended ethanol. (See Energy Information Administration, Petroloum Supply Monthly (Washington, DC, December 1993), p. xvil.) Prior years do not include field-blended ethanol. The unadjusted 1992 value (excluding field-blended ethanol) is 111.7 billion gallons. This value represents gasoline supplied for all pumposes.

Source: Energy Information Administration, Petroleum Supply Annual, Volume 1, Table S4 (various years).

total. ${ }^{62}$ In 1992, California, Texas, and Florida-the three highest consuming States-accounted for almost 25 percent of the gasoline consumed in the country. ${ }^{63}$

The number of vehicles, miles traveled per vehi :le, and average vehicle fuel efficiency (miles per gallon) all affect total gasoline consumption. Since automobiles dominate transportation gasoline consumption, changes in automobile consumption patterns affect total transportation gasoline consumption. Until recently, gasoline consumption had grown over the past 20 years as the number of automobiles and miles traveled per car grew (Table 13). During recessionary periods, such as the early 1980s, people drive less and consumption declines. Energy efficiency improvements in the past 20 years have helped to slow growth in gasoline consumption. After the oil embargo in 1973, fuel efficiency became a major concern. The Federal Government then implementeu Corporate Average Fuel Economy (CAFE) standards and reductions in speed limits on interstate highways. Auto manufacturers redesigned automobiles, reducing drag, weight, and friction and achieving better engine efficiency. Average on-road efficiency of the passenger car fleet rose from 13.3 miles per gallon in 1973 to 21.6 miles per gallon in 1992 (Table 13). In spite of efficiency improvements, however, the increased number of cars and miles driven per car, as well as greater use of light-duty trucks, have continued to drive up total gasoline consumption.

\section{Replacement Fuels in Gasoline: Methyl Tertiary-Butyl Ether and Ethanol}

Replacement fuels are a broader category of fuels than alternative fuels and include alternative fuels. As defined in EPACT, "the term 'replacement fuel' means the portion of any motor fuel that is methanol, ethanol, or other alcohols, natural gas, liquefied petroleum gas, hydrogen, coal derived liquid fuels, electricity (including electricity from solar energy), ethers, or any other fuel the Secretary of Energy determines, by rule, is substantially not petroleum and would yield substantial energy security benefits and substantial environmental benefits." Thus, in addition to alternative fuels, replacement fuels include ethers and alcohols used in lower volume percents with conventional fuels than defined by alternative fuels. Also, when replacement fuels are used in conjunction with conventional fuels (e.g., biodiesel and diesel combination fuel), only the portion of fuel volume composed of the replacement fuel (i.e., the biodiesel volume in this example) is considered to be replacement fuel.

Gasoline consumption discussed above includes volumes of the replacement fuels MTBE and ethanol. MTBE and ethanol used in small quantities with gasoline are considered replacement fuels. Increasing volumes of MTBE and ethanol have been added to gasoline over the past decade. Ethanol came into use as a gasoline "extender" (see Chapter 7). The product, gasohol, is a mixture of 10 percent ethanol and 90 percent gasoline, sometimes referred to as E-10. MTBE, an ether, was used as an octane enhancer to replace lead as a gasoline additive. When the Clean Air Act Amendments of 1990 mandated the use of oxygenates in gasoline, consumption of MTBE and ethanol, which are oxygenates, increased to meet this new demand for oxygenated gasoline. In 1992, oxygenated gasoline sales comprised over 30 percent of gasoline sales during the peak months (November and December) when all participating areas were using oxygenated gasoline. Table 14 shows the amount of ethanol and MTBE blended

\footnotetext{
${ }^{62}$ U.S. Department of Energy, Office of Transportation Technologies, Transportation Energy Data Book, Edition 13, ORNL-6743 (Oak Ridge, TN, March 1993), Table 2.7. Allocation of gasoline consumed to highway use and vehicle type is based on 1990 data.

${ }^{63}$ National Petroleum News, Vol. 85, No. 7 (Elk Grove Village, IL: Hunter Publishing Limited Partnership, Mid-June 1993), p. 103, citing Federal Highway Administration, Monthly Motor Fuels Report, December 1992, Table MF-33GA.
} 
Table 13. Automoblle Efficiency, 1973-1992

\begin{tabular}{|c|c|c|c|c|c|}
\hline & Year & $\begin{array}{l}\text { Regiotored Care } \\
\text { (Milliono) }\end{array}$ & Miles par Car & Callone par Car & Mlles per Callon \\
\hline 1973 & $\ldots \ldots \ldots \ldots$ & 102.0 & 10,256 & 771 & 13.30 \\
\hline 1974 & $\ldots \ldots \ldots \ldots$ & 104.9 & 9,606 & 716 & 13.42 \\
\hline 1975 & $\ldots \ldots \ldots \ldots \ldots$ & 106.7 & 9,690 & 716 & 13.52 \\
\hline 1976 & $\ldots \ldots \ldots \ldots$ & 110.2 & 9,785 & 723 & 13.53 \\
\hline 1977 & $\ldots \ldots \ldots \ldots \ldots$ & 112.3 & 9,879 & 716 & 13.80 \\
\hline 1978 & $\ldots \ldots \ldots \ldots \ldots$ & 116.6 & 9,835 & 701 & 14.04 \\
\hline 1979 & $\ldots \ldots \ldots \ldots$ & 118.4 & 9,403 & 653 & 14.41 \\
\hline 1980 & $\ldots \ldots \ldots \ldots$ & 121.6 & 9,141 & 591 & 15.46 \\
\hline 1981 & $\ldots \ldots \ldots \ldots$ & 123.1 & 9,186 & 576 & 15.94 \\
\hline 1982 & $\ldots \ldots \ldots \ldots$ & 123.7 & 9,428 & 566 & 16.65 \\
\hline 1983 & $\ldots \ldots \ldots \ldots$ & 126.4 & 9,475 & 553 & 17.14 \\
\hline 1984 & $\ldots \ldots \ldots \ldots$ & 128.2 & 9,558 & 536 & 17.83 \\
\hline 1985 & $\ldots \ldots \ldots \ldots$ & 131.9 & 9,560 & 525 & 18.20 \\
\hline 1986 & $\ldots \ldots \ldots \ldots$ & 135.4 & 9,608 & 526 & 18.27 \\
\hline 1987 & $\ldots \ldots \ldots \ldots$ & 137.2 & 9,878 & 514 & 19.20 \\
\hline 1988 & $\ldots \ldots \ldots \ldots$ & 141.3 & 10,121 & 509 & 19.87 \\
\hline 1989 & $\ldots \ldots \ldots \ldots$ & 143.1 & 10,332 & 509 & 20.31 \\
\hline 1990 & $\ldots \ldots \ldots \ldots$ & 143.5 & 10,548 & 502 & 21.02 \\
\hline 1991 & $\ldots \ldots \ldots \ldots$ & 142.6 & 10,757 & 496 & 21.69 \\
\hline $1992^{1}$ & $\ldots \ldots \ldots \ldots$ & 144.2 & 11,063 & 512 & 21.60 \\
\hline
\end{tabular}

'Data for 1992 are preliminary.

Note: Fuel used in these estimations represents gasoline and gasohol.

Sources: 1973-1985: Federal Highway Administration (FHWA), Highway Statistics Summary to 1985, Table VM-201A. 1966-1992: FHWA, Highway Statistics, FHWA-PL-003, Table VM-1.

Table 14. Replacement Fitel Use In Gasoline, 1992

\begin{tabular}{|c|c|c|}
\hline Fuel & $\begin{array}{c}\text { Volume } \\
\text { (Million Gallons) }\end{array}$ & $\begin{array}{c}\text { Percent of } \\
\text { Casoline }\end{array}$ \\
\hline Total Gasoline . . . . . & 110,135 & -- \\
\hline \multicolumn{3}{|l|}{ Replacement Fuols } \\
\hline MTBE $\ldots \ldots \ldots$ & 1,445 & 1.3 \\
\hline Ethanol $\ldots \ldots \ldots$ & 1,061 & 1.0 \\
\hline
\end{tabular}

Note: Fuels are for highway use only. It is assumed that most MTBE and fuel ethanol consumed are used in highway vehicles.

Source: Energy Information Administration, Petroleum Supply Monthly, DOE/EIA-0109(93/01) (Washington, DC, January 1993), Appendix D. into gasoline during 1992. Together they made up about $\mathbf{2 . 3}$ percent of the gasoline volumes sold in $\mathbf{1 9 9 2 .}$ The 1992 data reflect the beginning of the oxygenated gasoline requirements because the first oxygenated gasoline season began in the fall of 1992. (The data for 1993 will reflect the first full year of oxygenated requirements.)

\section{Reformulated Gasoline}

Although use of reformulated gasoline is not required until 1995, analysts are estimating the amounts of clean fuels $^{64}$ needed to serve the carbon monoxide and ozone nonattainment areas in the future. Table 15 illustrates, as a percentage of total gasoline production, the quantities of clean fuels potentially needed to serve nonattainment and opt-in areas in 1995. This estimate indicates that, by 1995, almost 60 percent of the gasoline produced will be serving nonattainment and opt-in areas, compared with about 30 percent in 1992, during peak oxygenated gasoline use months.

\footnotetext{
${ }^{64}$ In this report, clean fuels refers to those fuels meeting the CAAA standards for CO and ozone nonattainment areas when considered in combination with the vehicles using the fuels. For example, oxygenated gasoline is a clean fuel under this definition.
} 
Table 18. Percentage of Total Casolline sales Potentially Affected by Carbon Monoxide or Ozone Restrictions

\begin{tabular}{|c|c|}
\hline Carbon Monoxide Nonattainment Only ...... & $6.2 \%$ \\
\hline $\begin{array}{l}\text { Carbon Monoxide Nonattainment and Possible } \\
\text { Reformulated Opt-In .............. }\end{array}$ & $9.3 \%$ \\
\hline $\begin{array}{l}\text { Carbon Monoxide and Mandated Reformulated } \\
\text { Gasoline } \ldots \ldots \ldots \ldots \ldots \ldots \ldots \ldots\end{array}$ & $16.6 \%$ \\
\hline Mandated Reformulated Only $\ldots \ldots \ldots \ldots$ & $5.4 \%$ \\
\hline Possible Reformulated Opt-In Only & $22.4 \%$ \\
\hline Total Share of Casoline sales ........... & $50.9 \%$ \\
\hline
\end{tabular}

Notes: Based on State gasoline sales data for 1989. While some areas are required by the CAAA to use oxygenated or reformulated gasoline based on their air quality conditions, other areas are choosing to "opt-in" to the programs. See Chapter 5 for further explanation.

Source: American Petroleum Institute, Meoting Oxygenate Requirements of 1990 CAA, Pub. No. 58058 (Washington, DC, June 1991), pp. 34-37.

\section{Dlesel Consumption}

Diesel fuel, like gasoline, is derived from crude oil, and is the second largest transportation fuel being used today. It serves primarily a commercial, heavy-duty fleet vehicle market. In 1992, diesel fuel consumed for highway use was 21.4 billion gallons (Table 16). As with gasoline, California and Texas are the two largest consuming States, but Pennsylvania is the third highest (compared with Florida for gasoline). These three States accounted for more than $\mathbf{2 0}$ percent of all diesel consumed in highway use in $1992 .{ }^{65}$ Although consumption by vehicle type is not available for 1992, trucks in 1990 used 92 percent of highway diesel, and automobiles and buses each used only 4 percent. ${ }^{66}$

Table 16. Highway Dioeel Domand, 1887-1992 (Million Gallons)

\begin{tabular}{|c|c|c|}
\hline 1987 & $\ldots \ldots \ldots \ldots \ldots \ldots \ldots$ & 18,173 \\
\hline 1988 & $\ldots \ldots \ldots \ldots \ldots \ldots \ldots$ & 20,039 \\
\hline 1989 & $\ldots \ldots \ldots \ldots \ldots \ldots$ & 21,132 \\
\hline 1990 & $\ldots \ldots \ldots \ldots \ldots \ldots$ & 21,360 \\
\hline 1991 & $\ldots \ldots \ldots \ldots \ldots \ldots$ & 20,485 \\
\hline 1992 & $\ldots \ldots \ldots \ldots \ldots \ldots$ & 21,375 \\
\hline
\end{tabular}

Source: Federal Highway Administration (FHWA), Statistics of Highway Special Fuels Use, taken from Energy Information Administration, Fuel Oll and Kerosene Sales, 1991 and 1992, Table 1.

${ }^{65}$ Energy Information Administration, Fuel Oil and Kerosene Sales 1992, DOE/EIA-0535(91) (Washington, DC, October 1993), Table 4.

${ }^{6}$ U.S. Department of Energy, Office of Transportation Technologies, Transportation Energy Data Book, Edition 13, ORNL-6743 (Oak Ridge, TN, March 1993), Table 2.7. 


\section{Greenhouse Gas Emissions and Replacement Fuels}

This chapter presents information ${ }^{67}$ on how replacement fuels may impact greenhouse gas emissions, compared with conventional transportation fuels. The discussion is a qualitative response to the requirements of Section 503 (a)(4) of EPACT. Preceding this discussion is a brief introduction to greenhouse gases and why they are of concern. Detailed background information on greenhouse gases, transportation fuels, and related emission issues can be found in Chapter 10. A review of energy and greenhouse gases is contained in the EIA report Emissions of Greenhouse Gases in the United States 1985-1990, DOE/EIA-0573 (September 1993).

Greenhouse gases are those which either: (1) trap heat and prevent its radiation back into the stratosphere and beyond, thus warming the Earth or (2) reflect sunlight, preventing its entering the troposphere and striking the Earth's surface, thus cooling the Earth. The Earth's capacity to support life depends on the moderating influences of some gases which envelop the planet, warm its surface, and protect it from harmful radiation. ${ }^{60}$ Increases in greenhouse gases, however, are thought by many to contribute to an observed global warming trend. Since the mid-19th century, the trend has been toward a warmer Earth with a rising sea level. This trend has accelerated over the last $\mathbf{4 0}$ years, with the sea level now rising around 1.75 centimeters $(0.7$ inch) per decade. This may be explained by several factors, including the increasing concentration of greenhouse gases in the Earth's lower atmosphere (troposphere) (Figure 2). ${ }^{69}$ The troposphere is the first 6 miles of the atmosphere (which is 600 miles thick). The relative contribution of greenhouse gases to global warming is uncertain.

While the list of greenhouse gases is lengthy, the principal ones are carbon monoxide, nitrous oxide, methane, carbon dioxide, and water vapor. ${ }^{70}$ Greenhouse gases are released into the atmosphere as the result of a large number of natural and human (anthropogenic) activities. One of the major anthropogenic sources of greenhouse gases is energy production and consumption. Fuels such as coal, natural gas, and all petroleum products contain varying amounts of carbon. The greater the consumption of fossil fuels, the greater the emission of greenhouse gases.

Because mobile sources are estimated to emit a significant percentage of U.S. anthropogenic greenhouse gases (Table 17), concern about possible greenhouse-gasinduced warming is motivating development and use of transportation fuels with reduced greenhouse effects. The concern is not just about the combustion of transportation fuels but also with the entire vehicle and fuel cycle. This includes:

- End use: emissions from the evaporation and combustion of the final fuel product

- Distribution: emissions from the delivery of fuel to local retailers

- Process: emissions from the actual fuel production, including fuel compression and liquefaction

- Recovery of fuel feedstock: emissions from the acquisition of fuel from the resource base, including land use conversion (e.g., clearing land for growing corn, clear-cutting trees to drill an oil well)

- Transportation of feedstock: emissions from the delivery of new feedstock to the production plants

- Assembly and manufacture of materials used in vehicle production: emissions from vehicle assembly and manufacturing operations.

About 25 metropolitan regions are required under the CAAA to develop plans for reducing air pollution to meet Federal health standards. Several of the greenhouse gases (e.g., carbon dioxide, methane, and water vapor) are not regulated, while nitrous oxide and ozone

\footnotetext{
${ }^{67}$ This report does not take a position on the scientific validity of any global climate theory but presents the reader with the rationale behind the theories and concerns which have led to the EPACT requirement for information on greenhouse gases.

cEnergy Information Administration, Emissions of Greenhouse Gases in the United States 1985-1990, DOE/EIA-0573 (Washington, DC, September 1993), p. ix.

'Other factors include elliptical distance from the sun, lack of major volcanic activity, burnup of radioactive elements in the earth's core, earth wobble, and variations in inclination toward the sun.

${ }^{\pi}$ Chlorofluorocarbons are also a principal greenhouse gas. However, they are not discussed in this chapter because they are not produced from the combustion of fuel.
} 
Figure 2. Levels of the Earth's Almosphere

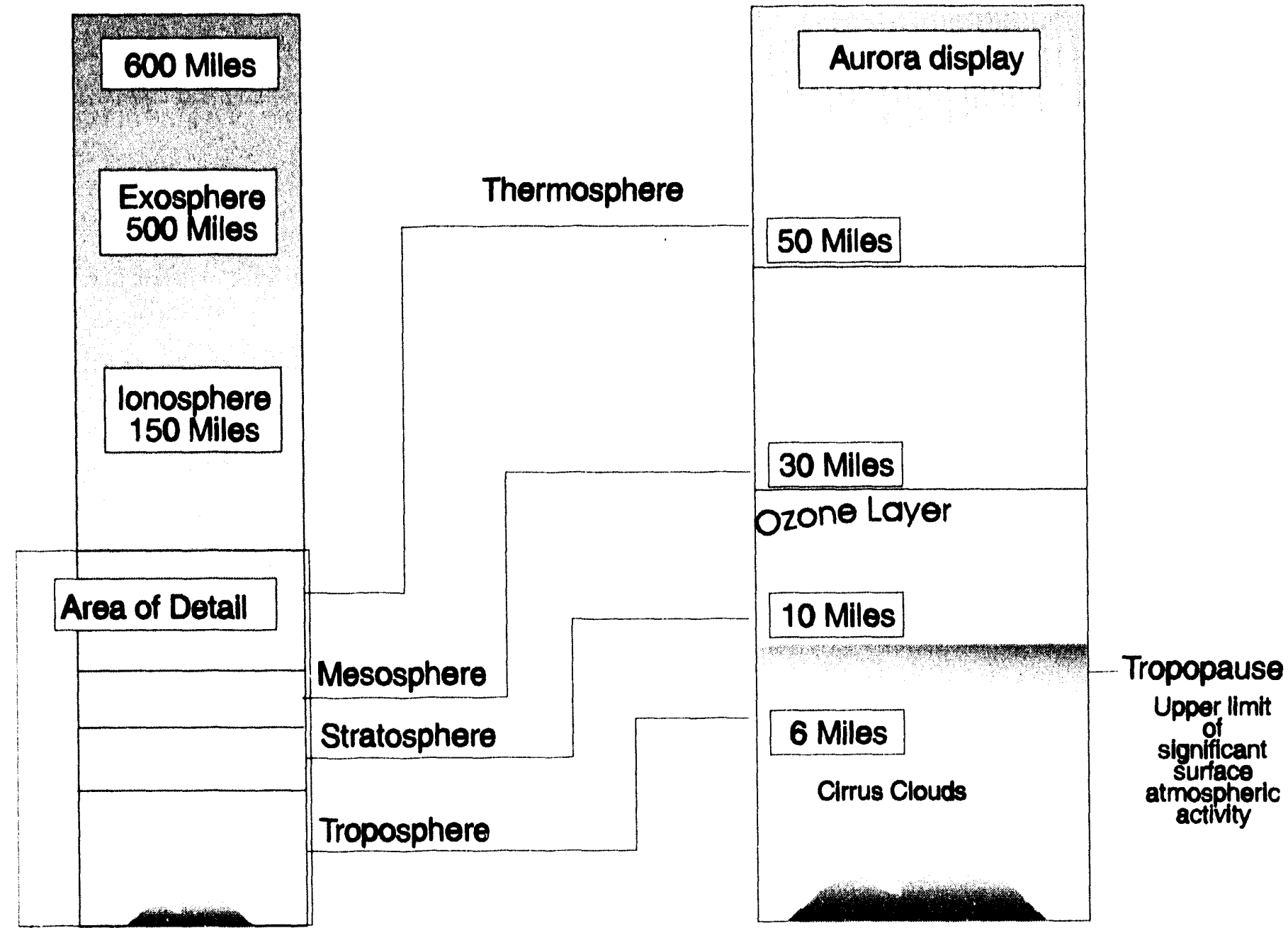

Source: Time Incorporated Book Company, Weather and Climate (Richmond, VA, 1993), p. 8.

precursors are. End-use energy consumption produces substantial amounts of several harmful pollutants. However, data scarcity and measurement uncertainties surrounding the greenhouse effect make it difficult to estimate the contribution of a fuel's consumption to the total emissions of a particular greenhouse gas over the entire fuel cycle.

It is even more difficult to estimate the displacement of greenhouse gases which would result from the use of replacement fuels. (Recall that "replacement fuels" include oxygenate additives to conventional fuels as well as alternative transportation fuels.) An initial effort at addressing this problem is to determine which greenhouse gases are emitted as the result of each potential transportation fuel. This affords one level of comparison of ATFs with gasoline and diesel. The next step is to determine whether a given ATF produces more or less of a greenhouse gas than do conventional fuels (Table 18).

Although there is great uncertainty surrounding the measurement of greenhouse gases from replacement fuels, some information is available. All replacement fuels emit less carbon dioxide than does gasoline. Most of the replacement fuels also emit less carbon monoxide-potentially helpful in NAAQS carbon monoxide nonattainment areas. MTBE and ethanol, additives used in oxygenated and reformulated gasoline, ${ }^{71}$ emit lesser quantities of some greenhouse gases than gasoline does when burned. In the case of ethanol, however, some emissions are greater in the other stages of its fuel cycle than those for standard gasoline. The net effect is probably very small. Whether ethanol gives a net green-

${ }^{n}$ Ethanol is also being considered as a separate fuel. 
Table 17. Emissions of Selected Greenhouse Gases from Moblle Sources, 1985 and 1991

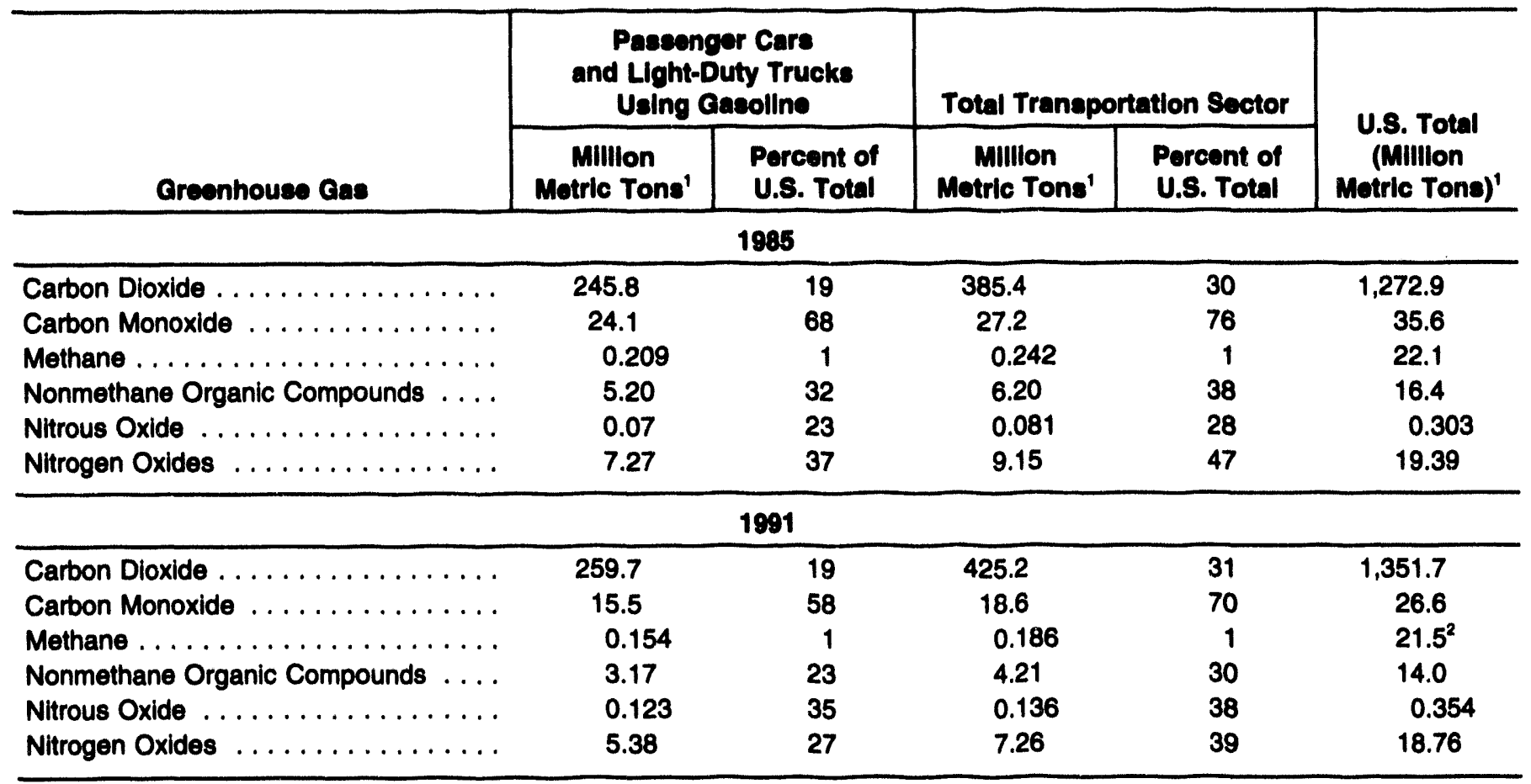

\footnotetext{
'Emissions of carbon dioxide, carbon monoxide, methane, and nonmethane organic compounds are shown in terms of million metric tons of carbon. Emissions of nitrous oxide and nitrogen oxides are shown in terms of million metric tons of gas.

${ }^{2}$ With 1991 estimated landfill methane emissions of 10.5 million metric tons of methane.

Source: Energy Information Administration, Emissions of Greenhouse Gases in the United States 1985-1990, DOE/EIA-0573 (Washington, DC, September 1993), and errata sheets.
}

house emission benefit depends on the warming potential of the different emissions. This is an area of extreme controversy.

Similar controversies surround several of the other alternative fuels. The CNG fuel cycle, for example, generates considerably less carbon dioxide than the gasoline fuel cycle but considerably more methane. Uncertainty over the warming potential of methane relative to carbon dioxide creates uncertainties over the net effect of substituting CNG for gasoline.

Two other controversial issues are the greenhouse impact of reformulated gasoline and the effect of displacing diesel fuel. Reformulated gasoline is designed to reduce the emissions of volatile organic compounds (i.e., smog precursors). This reduction in smog-related emissions tends to increase the net production of greenhouse gases, e.g., $\mathrm{CO}_{2}$. The diesel fuel cycle, meanwhile, is a smaller contributor to greenhouse gas emissions than is the gasoline fuel cycle. The particularly objectionable emissions from diesel fuel combustion-particulate matter-tend to have little greenhouse impact. Thus, displacement of diesel fuel by ATFs may offer local air quality improvement but increase greenhouse emissions.

\section{Future Plans}

Future reports will represent the greenhouse gases resulting from replacement fuel use across the entire fuel cycle in several important ways. While Table 18 represents the best and most current data available, some continue to be controversial; in fact, some questions remain unanswered. Subsequent publications will update and extend the table, as appropriate. Future reports will also attempt to address regional issues in a manner which relates to important concerns.

While Section 503 of EPACT requires life-cycle data on greenhouse gases, tailpipe emissions often dominate regional clean air discussions. Winter emissions in carbon monoxide nonattainment areas may be relatively important, as may summer emissions in ozone nonattainment areas. In both cases, emissions from refueling, evaporation, and combustion of transportation fuels contribute to the air quality problems. Since 
Table 18. Total FuetCycle Emissions from Gasoline and from Replacement Fuels

\begin{tabular}{|c|c|c|c|c|c|c|c|}
\hline \multirow[b]{2}{*}{ Emisolons } & \multirow{2}{*}{$\begin{array}{c}\text { From } \\
\text { Gasoline }\end{array}$} & \multicolumn{6}{|c|}{ From Replacement Fuels, Rolative to Gasoline } \\
\hline & & MTEE' & Ethanol & LPG & CNG & M-85 & Electric ${ }^{3}$ \\
\hline \multicolumn{8}{|l|}{ Creonhouse Cases" } \\
\hline Water Vapor . . . . . . . . . . . & Yes & More & More & More & More & More & Less \\
\hline Carbon Dioxide $\left(\mathrm{CO}_{2}\right)^{5} \ldots \ldots$ & Yes & Less & Less & Less & Less & Less & a \\
\hline Carbon Monoxide (CO) . . . . . . & Yes & Less & Equalless & Less & Less & Equal & Less \\
\hline Nitrogen Oxides $\left(\mathrm{NO}_{x}\right)^{6} \ldots \ldots$ & Yos & Equal & More/Equal ${ }^{7}$ & Equal & Equal & Equal & \\
\hline Nitrous Oxide $\left(\mathrm{N}_{2} \mathrm{O}\right) \ldots \ldots \ldots$ & Yes & $\mathbf{a}$ & a & a & a & a & a \\
\hline \multicolumn{8}{|l|}{ Volatile Organis Compounds" } \\
\hline Motheno $\ldots \ldots \ldots \ldots \ldots \ldots$ & Yes & Equal & Equal & More & More & Equal & Less \\
\hline Ethane $^{10} \ldots \ldots \ldots \ldots \ldots \ldots$ & Yes & Equal & Equal & Equal & Equal & Equal & Less \\
\hline Total Ozone Precursors" ${ }^{11} \ldots .$. & Yes & Less & More/Less ${ }^{12}$ & Less & Less & Less & Less \\
\hline \multicolumn{8}{|l|}{ Nonmothane Organic Compounds } \\
\hline Methanol $\ldots \ldots \ldots \ldots \ldots \ldots$ & No & More & No & No & No & More & No \\
\hline Ethanol $\ldots \ldots \ldots \ldots \ldots$ & No & No & More & No & No & No & No \\
\hline Formakdehyde $\ldots \ldots \ldots \ldots \ldots$ & Yes & More & More & Equal & Equal & More & Less \\
\hline Acetaldehyde ............. & Yes & Less & More & Less & Equal & Equal & Less \\
\hline Sultur Oxides' ${ }^{12} \ldots \ldots \ldots \ldots \ldots$ & Yes & Less & Less & No & No & Less & More \\
\hline Particulato Matter 14 . . . . . . . & Yes & Less & Less & Less & No & No & More \\
\hline
\end{tabular}

"Results are uncertain because emissions vary widely, depending on the engine's compression, temperature, and fuel/oxygen mix.

'Consumed with the gasoline in which it was blended.

Includes ethanol in gasohol and ethanol as E-85.

'Life-cycle emissions from electric vehicles depend on the utility feedstock; these projections assume that the feedstock is mostly coal, as more than half of electricity today is generated from coal.

'Greenhouse gas emission impacts are highly dependent on the feedstock used for fuel production.

${ }^{5} \mathrm{CO}_{2}$ emissions vary widely. In some cases, emissions could be either higher or lower than gasoline, depending on the feedstock and method of production.

Nitrogen oxides are not a direct greenhouse gas but rather contribute through tropospheric ozone formation.

'More for splash-blended gasohol with higher Reid vapor pressure; equal for gasohol with controlled Reid vapor pressure (not splash-blended) and for E-85/E-100.

Methane and ethane are just two of hundreds of volatile organic compounds. Others, such as hydrocarbons from unburned fuel and partial combustion, are not reported here.

'Does not participate in atmospheric photochemical reactions.

${ }^{10}$ Does not participate in atmospheric photochemical reactions.

"Ozone precursors include $\mathrm{NO}_{x}$ and nonmethane organic compounds.

${ }^{12}$ More if splash-blended gasohol but less if specially reformulated gasohol or E-85/E-100.

${ }^{13}$ This category includes sulfones. While most greenhouse gases contribute to global warming, the sulfates cool the atmosphere. Among the transportation fuels, sulfur oxides are emitted mostly from diesel fuel.

14 Most particulate matter emissions in the transportation sector come from diesel fuel.

Notes: MTBE, methyl tertiary-butyl ether; LPG, liquetied petroleum gas (propane); CNG, compressed natural gas.

Sources: See Appendix D, references 16 through 20. 
carbon monoxide and certain ozone precursors are greenhouse gases, these emissions are a regional concern even though the global warming problem is not.

The most commonly available emissions data comes from tailpipe measurements, yet these by themselves are misleading because refueling and evaporative emissions may contribute more to a nonattainment area's problem than those from vehicles' tailpipes. Regional representations for vehicular emissions address local air quality, but may miss the more global problems from the emissions, especially those in air corridors downwind from a fuel's resource recovery, production, transmission, and distribution. High population density areas which maintain their attainment status may be doing it through use of replacement fuels. Only by portraying actual emissions over the entire fuel cycle for each fuel can a valid comparison be made-and then possibly only for the affected region(s).

Also, the chemical species considered to be greenhouse gases may be changed in future reports. Nonmethane organic compounds is a category which encompasses dozens of discrete chemical species, some of which deserve to be treated separately. Future reports may address both these issues and that of the thermal energy emitted during the fuel cycle. Since heat does not simply disappear but warms the atmosphere and, for example, changes the rate of ozone formation, quantification of the energy released into the environment seems logical.

\section{Caveats}

Some emissions may not have been measured systematically using standardized calibration and quality control procedures. Others may not have been measured but have been assumed to be constant or nonexistent. In lieu of measurements, allowable limits from regulations may have been substituted in the emissions estimates. While substitution is an expedient technique when data are lacking, actual data need to be collected, published, and used to avoid the otherwise potentially misleading results. Future research will lead to changes which are not predictable.

Further, previously minimized but important aspects should be rigorously addressed. For example, technology changes incorporating desired improvements which reduce emissions may make extrapolating the current status invalid. Dated material and assumptions, however, cannot be avoided in the current (or any) snapshot or portrait of replacement fuel usage. Therefore, subsequent measurements may support different conclusions (i.e., Table 18 entries of "less," "equal" or "more" emissions than gasoline may change). 
Section 2

Technology 


\section{Legislation Affecting Use of Alternative Fuels}

\section{Background}

Growing concern about the economy, environment, air quality standards, and the dependence of the United States on foreign oi resulted in legislation designed to increase the use of alternative transportation fuels (ATFs) and replacement fuels. Three major Acts-the Clean Air Act Amendments of 1990 (CAAA, Public Law 101-549), the Alternative Motor Fuels Act of 1988 (AMFA), and the Energy Policy Act of 1992 (EPACT)as well as a number of executive orders are primarily responsible for providing the impetus in research, development, and use of alternative fuels. A recent directive, Executive Order 12844 signed by President Clinton on April 21, 1993, ensured that Federal agencies exercise leadership in the use of alternative fueled vehicles.

\section{Clean Air Act Amendments of 1990}

The Clean Air Act of 1963 was the first modern environmental law which recognized air quality as a problem. Subsequent amendments made in 1970, 1977, and 1990 strengthened enforcement of the original law and are motivating air quality regulation and reform today. The Act and its Amendments established the Federal-State relationship that required the U.S. Environmental Protection Agency (EPA) to develop uniform air-quality standards (NAAQS) ${ }^{72}$ and empowered the States to implement and enforce regulations to attain them. ${ }^{73}$ These laws also required EPA to set NAAQS for six common and widespread pollutants: sulfur dioxide, particulate matter, nitrogen dioxide, carbon monoxide (CO), ozone, and lead. ${ }^{74}$ Prolonged exposure to these pollutants at certain levels of concentration may endanger public health and welfare. ${ }^{75}$

The Amendments of 1990 added a significant number of specific control programs and strengthened the enforcement authority of the original law. New provisions emphasized fuels and vehicle operating characteristics (improved gasoline formulations, new fuels, and cleaner cars), offroad engines (locomotives, boats, farm equipment, bulldozers, lawn and garden devices), and alternative transportation programs in seriously polluted areas (ridesharing, use of commuter trains, etc., aimed at reducing the amount of highway traffic). Tailpipe emission standards for cars, buses, and trucks were made more stringent, as were the testing requirements of vehicle inspection/maintenance (I/M) programs. These programs were also broadened to include more areas. And, for the first time, the CAAA considered improvement in both fuel and vehicle technologies as strategies for emission reduction. More stringent enforcement has apparently been successful. Between 1982 and 1991, ozone levels decreased by 13 percent, and $\mathrm{CO}$ levels decreased by 31 percent. $^{76}$

The CAAA of 1990 created two new thrusts affecting nonpetroleum content of transportation fuels: (1) a gasoline oxygen content requirement in $\mathrm{CO}$ and ozone nonattainment areas, and (2) a requirement for "clean cars" in California and for fleet AFVs in the approximately two dozen or so worst ozone nonattainment areas. EPA designates areas as being in "nonattainment" according to the degree they exceed the NAAQS. ${ }^{7}$ There are five nonattainment categories specified in the CAAA: EXTREME, SERIOUS, SEVERE,

\footnotetext{
The NAAQS are threshold concentrations based on scientific documents prepared by EPA and peer reviewed.

${ }^{73}$ EPA established the primary and secondary NAAQS for ozone (originally called NAAQS for oxidants) in the 1970s. Congress set and extended various timeframes (1975, 1982, 1987) for meeting the NAAQS for compliance with ozone and carbon monoxide.

${ }^{7}$ For each pollutant, NAAQS comprise a primary standard, which is intended to protect the public health with a margin of safety, and a secondary standard, which is intended to protect the public welfare as measured by the effects of the pollutant on vegetation, materials, and visibility.

${ }^{73}$ National Research Council, Committee on Tropospheric Ozone Formation and Measurement, Rethinking the Ozone Problem in Urban and Regional Air Pollution (Washington, DC: National Academy Press, 1991).

ॠU.S. Environmental Protection Agency, Office of Quality Planning and Standards, National Air Quality and Emissions Trends Report (Washington, DC, 1991), pp. 4 and 10.

7National Research Council, Committee on Tropospheric Ozone Formation and Measurement, Rethinking the Ozone Problem in Urban and Regional Air Pollution (Washington, DC: National Academy Press, 1991).
} 
MODERATE, and MARGINAL. An area's air pollution classification depends on its ozone design value ${ }^{78}$ and the percentage by which the value is greater than the NAAQS. Separate classification schemes are included for $\mathrm{CO}$ and particulate matter (PM-10). ${ }^{79}$

An area can be redesignated as being in attainment with the NAAQS if the following conditions are met: ${ }^{80}$

- The area has complete air quality data meeting the national air quality standards

- The area has a fully approved State Implementation Plan meeting CAAA requirements

- The area has an approved maintenance plan, including contingency plan, showing attainment for 10 years

- The improvement in air quality is due to permanent and enforceable reductions in emissions

- All applicable CAAA requirements have been met.

Although there has been some improvement in air quality, 94 U.S. cities ${ }^{81}$ still do not meet ozone (smog) standards under the CAAA. Forty-one areas ${ }^{82}$ took corrective steps to reduce $\mathrm{CO} .{ }^{33}$ Another 67 areas of the country do not meet the air quality standards for particulate matter (soot and dust from woodstoves, factories, agricultural sources, and diesel engines). ${ }^{84}$

In keeping with the responsibility of the EIA under Section 503 of EPACT, the discussion below of the CAAA will be limited to the "clean fuel" data collection provisions which encourage the use of alternative and replacement fuels and fuel additives. These requirements include oxygenated fuels, reformulated gasoline, the clean-fuel fleet program, the California Pilot Program, and transit bus provisions. Emission standards are discussed later in this report.

The CAAA did not mandate the use of alternative fuels but included several programs that encouraged cleaner fuels and opened up the fuel market to nonpetroleum additives. These provisions modified the content of gasoline and established stricter emission standards for vehicles in designated nonattainment areas. The clean fuel provisions of the CAAA follow.

\section{Oxygenated Fuels}

Beginning in November 1992, $39 \mathrm{CO}$ nonattainment areas were required to use oxygenated fuels ${ }^{85}$ during the winter because the areas were prone to high seasonal ambient concentrations of $\mathrm{CO}$. Oxygenates such as MTBE, produced from methanol and isobutylene, and ethanol displace petroleum and reduce $\mathrm{CO}$ pollutants from automobile emissions. The gasoline used for the 4-month period through February contained no less than 2.7 percent oxygen by weight (except California, which has an EPA waiver to use 2.0 percent). The use of oxygenated gasoline during the winter of 1992-93 appears to have been successful in reducing $\mathrm{CO}$. Table 19 indicates an apparent pattern of reduction from 1987 to 1993. By 2010 , up to 500,000 barrels per day of gasoline could be replaced by oxygenates under this program. ${ }^{86}$

\section{Table 19. Carbon Monoxide Exceedances In Areas With Oxygenated Fuel Programs (Except Callfornia), 1987-1983}

\begin{tabular}{c|c|cccc}
\hline Period & November & December & January & Total \\
\hline $11 / 87-1 / 88$ & $\ldots$ & 38 & 38 & 56 & 132 \\
$11 / 88-1 / 89$ & $\ldots$ & 16 & 50 & 31 & 87 \\
$11 / 89-1 / 90$ & $\ldots$ & 20 & 76 & 17 & 113 \\
$11 / 90-1 / 91$ & $\ldots$ & 16 & 15 & 25 & 56 \\
$11 / 91-1 / 92$ & $\ldots$ & 14 & 14 & 15 & 43 \\
$11 / 92-1 / 93$ & $\ldots$ & 1 & 1 & 0 & 2 \\
\hline
\end{tabular}

Source: U.S. Environmental Protection Agency, Office of Air Quality Planning and Standards, National Air Quality and Emissions Trends Report, 1991, 450-R-92-001, October 1992, pp. 4-22.

\footnotetext{
${ }^{78}$ Ozone design values are statistically determined from ozone concentration measurements for each nonattainment area. These design values are used to determine the extent of control needed for an area to reach attainment.

${ }^{79} \mathrm{~A}$ class of particulate matter of or below 10 micrometers in diameter.

${ }^{80}$ U.S. Environmental Protection Agency, Office of Air Quality and Planning, National Air Quality and Emissions Trends Report (Washington, DC, 1992).

${ }^{81}$ U.S. Environmental Protection Agency, Office of Quality Planning and Standards, National Air Quality and Emissions Trends Report (Washington, DC, 1992).

${ }^{82}$ The numbers of ozone and $\mathrm{CO}$ nonattainment areas are changing as areas are redesignated to attainment.

${ }^{83}$ Every nonattainment area listed by EPA is either a metropolitan statistical area (MSA) or a consolidated metropolitan statistical area (CMSA) as designated by the U.S. Census Bureau. However, EPA expanded MSAs and CMSAs to include any area with a population over 250,000, according to the 1980 census. (This equates to another 125 MSAs and CMSAs.)

${ }^{84}$ U.S. Environmental Protection Agency, Office of Air Quality Planning and Standards, Research Triangle, NC, April 1994.

${ }^{85}$ Oxygenated fuels contain minimal concentrations of oxygen (includes oxygen-bearing compounds such as ethanol and methanol) in order to decrease CO emissions.

${ }^{86}$ Congressional Research Service, Alternative Transportation Fuels: Oil Imports and Highway Tax Issues (Washington, DC, February 18, 1994).
} 
Although not yet in commercial use, biodiesel, a biomass-derived fuel, can be used to replace conventional diesel fuel or as an oxygenate in diesel fuel. Biodiesel not only imparts oxygen to the blend but also reduces particulate and sulfur emissions proportional to its percentage in the blend. Biodiesel can also be used as a feedstock at refineries.

\section{Roformulated Gasoline}

EPA will regulate the content of reformulated gasoline $^{87}$ (RFG) by two sets of standards based on (1) the maximum allowable percentage (by weight) of toxic components $^{88}$ and potential atmospheric reactants in the fuel itself and (2) the maximum allowable levels of exhaust emission of toxic components and atmospheric reactants. The EPA oxygen-content requirements for RFG, like oxygenated gasoline, include oxygenates such as MTBE, produced from methanol and isobutylene, and ethanol. By 1995, all gasoline sold in the nine worst ozone areas ${ }^{89}$ must meet the performance criteria or contain a minimum oxygen content by weight and a maximum benzene content by volume. Many other areas of the country can and have "opted-in" to the reformulated gasoline program. Several content- or performance-based standards must be met, including a minimum oxygen content of 2 percent by weight in RFG. RFG must also reduce emissions of harmful and smog-forming compounds by at least 15 percent without increasing emission of nitrogen oxides. If a fuel supplier chooses a performance-based fuel, the reformulation can be treated as a proprietary product. By 2000, gasoline sold in ozone nonattainment areas must reduce emissions of harmful and smog-forming agents such as oxides of nitrogen $\left(\mathrm{NO}_{\mathrm{x}}\right)$ and volatile organic compounds (VOCs) by at least 20 to 25 percent. ${ }^{90}$

The nine worst nonattainment areas must use RFG. Cities in other nonattainment areas (approximately 90) may elect to use this cleaner gasoline. Supply is not anticipated to be a problem. All member States of the Northeast Ozone Transport Commission (OTC) which have nonattainment areas have formally requested to opt-in to the EPA RFG program. The OTC Region includes 11 States extending from Maine to Maryland, the District of Columbia, and the contiguous metropolitan section of Virginia.

\section{Callfornia Pilot Program}

The California Pilot Program sets nonmethane hydrocarbon emission standards for fleet vehicles in that State beginning with the 1996 model year. The sales requirement is 150,000 "clean" vehicles per year (capable of meeting a 0.125 grams per mile (gpm) nonmethane hydrocarbon, $3.4 \mathrm{gpm} \mathrm{CO}$, and $0.4 \mathrm{gpm} \mathrm{NO}$ standard) in 1996-1998, and 300,000 vehicles per year after that. ${ }^{91} \mathrm{NO}_{\mathrm{x}}$ emission standards will be lowered even further in 2001.

It now appears, however, that the Pilot Program will be satisfied by the California Low-Emission Vehicle (LEV) program. EPA has already approved a waiver for the LEV program, and gasoline is expected to meet most of the LEV requirements.

\section{Clean-Fuel Fleet Program ${ }^{2}$}

This program was intended to stimulate development of new, low-polluting fuel/vehicle combinations. As enacted by statutes in 1990, the program affected 22 nonattainment areas in 19 States across the country. Since 1990, various rulemakings and State options have been put in place, which allow States to either "opt-in" or "opt-out" of the program. Beginning in 1998, about one-third of new vehicles that are purchased by centrally fueled fleets will be required to use clean fuels and meet more stringent tailpipe standards $(0.075 \mathrm{gpm}$ hydrocarbons, $3.4 \mathrm{gpm} \mathrm{CO}$, and $0.2 \mathrm{gpm} \mathrm{NO}$ ) than currently in place for general passenger cars. Current tailpipe standards for cars are $0.41 \mathrm{gpm}$ hydrocarbons, $3.4 \mathrm{gpm} \mathrm{CO}$, and $1.0 \mathrm{gpm} \mathrm{NO}{ }^{93}{ }^{93}$ These purchase requirements will grow to 70 percent by 2000 .

It is expected that RFG will be able to meet the lower standards, although some fleets may consider fuels such as natural gas or LPG, which can offer potential $\cos$ savings. EPA estimates that the program will affect

\footnotetext{
${ }^{87}$ Reformulated gasoline is gasoline whose composition is modified to include (1) oxygenates; (2) reduction in content of olefins, aromatics, and volatile components; and (3) reduction in content of heavy hydrocarbons to meet performance specifications for ozoneproducing tendency and for release of harmful substances. See Chapter 7 for further information on reformulated gasoline.

${ }^{80}$ Toxic air pollutants being restricted under Section 219 of the CAAA are the aggregate emissions of benzene, 1,3-butadiene, polycyclic organic matter, acetaldehyde, and formaldehyde.

The nine worst areas for ozone are Los Angeles, Houston, New York, Baltimore, Chicago, San Diego, Philadelphia, Milwaukee, and Ventura.

${ }^{90}$ U.S. Department of Energy, Office of Energy Demand Policy, Final Report of the Interagency Commission on Alternative Motor Fuels, DOE/EP-0002P (Washington, DC, September 1992), p. A-2.

${ }^{91}$ U.S. Environmental Protection Agency, Office of Mobile Sources, Motor Vehicles and the 1990 Clean Air Act.

"This is an abbreviated name for "Clean-Fuel Centrally Fueled Fleet Program" used in the Final Report of the Interagency Commission on Alternative Motor Fuels.

${ }^{93}$ U.S. Environmental Protection Agency, Office of Mobile Sources, Fuels and the 1990 Clean Air Act, p. 3.
} 
approximately 35,000 fleets and should result in about 1 million new clean-fueled vehicles by the year 2010, not counting traditionally fueled cars optimized for RFG.

As part of the Clean-Fuel Fleet Program, fleet operators may voluntarily choose to purchase vehicles certified as Inherently Low-Emission Vehicles (ILEVs). ILEVs meet the fleet exhaust emission standard as well as a very stringent evaporative standard. Because of their clean air benefits, these vehicles will be exempt from highoccupancy vehicle lane restrictions and possibly from other travel restrictions in the future. While any fuelvehicle combination that meets the emission standards may qualify as an ILEV, it is expected that this program will be most easily met by alternative fuels.

\section{Transit Bus Provisions}

Beginning in model year 1994, the particulate matter emission standard for all new urban buses is tightened to 0.05 gram per brake-horsepower-hour ( $/$ / bhph). ${ }^{95}$ EPA will evaluate whether buses can comply with the more stringent standard. If not, EPA will establish a low-polluting fuels requirement beginning in the late 1990 s which would affect urban buses in MSAs or CMSAs with populations of 750,000 or more. Under this contingent program, transit buses will be required to operate exclusively on methanol, CNG, ethanol, LPG, and other low-polluting fuels. The program could be extended to smaller urban areas for health benefits.

The timetable on the following page is a proposed schedule through the 1990s of the beginning dates for various programs. ${ }^{\circ 6}$ The 1990 CAAA are of a magnitude and complexity that will impact the next decade(s) and future fuel markets, particularly for nonpetroleum additives. Future decisions about the kind of vehicles we drive, the fuels we use, and how we live will ultimately be a result of the Clean Air Act legislation.

\section{Alternative Motor Fuels Act of 1988}

The AMFA created a program of modest financial support for research, development, and demonstration for both vehicles and fuels, plus fuel economy credits for carmakers' Corporate Average Fuel Economy (CAFE) programs. ${ }^{97}$ AMFA encouraged the development and use of alternative transportation fuels pri- marily by authorizing Federal agencies to pay any additional costs for purchasing alternative fueled vehicles over their conventional-fuel counterparts. The purpose of the legislation was to help enhance energy security, improve air quality, and encourage the production of methanol-, ethanol-, and natural-gaspowered motor vehicles. It funded mostly fleet programs in Federal Government agencies. The intention of the Act was to help alternative transportation fuels toward the threshold level of commercial application and consumer acceptability. EPACT subsumed many AMFA provisions, repealed some, and expanded others. For example, a major change in AMFA by EPACT was to expand the number of fuel categories to include LPG, coal-derived liquid fuels, other biofuels, and electricity.

AMFA program activities include the following: ${ }^{96}$

- Additional alternative fueled vehicles are planned to be added to the light-duty vehicle program in fiscal year 1994. The amended version of AMFA allows for all alternative fuel types (LPG, electricity, etc.) to be acquired for the program.

- EPACT makes a number of amendments to the AMFA program, including repeal of the termination date of September 30,1997, for DOE's programs on data collection for light-duty vehicles, alternative fueled truck commercialization, and alternative fuel buses.

- DOE has developed an expanded emission test plan for the light-duty vehicle fleet for fiscal year 1993. The overall objective is to ensure the accurate measurement, collection, dissemination, and analysis of mass emissions data from the fleet so that differences in vehicle emissions when using alternative fuels and conventional fuels can be determined. In addition, EPACT adds statutory requirement for the wide adoption of AFVs in normal Federal fleet operations. This has been amplified by Executive Order 12844, which directs agencies to exceed the EPACT AFV acquisition requirements by 50 percent.

AMFA directed DOE to collaborate on a number of actions with the General Services Administration (GSA), DOT, EPA, and other agencies to promote the development and widespread use of alternative transportation fuels. As a result, an Interagency Commission on Alternative Motor Fuels was formed to coordinate and

\footnotetext{
M.S. Environmental Protection Agency, Office of Mobile Sources, Fuels and the 1990 Clean Air Act, p. 3.

${ }^{9}$ U.S. Department of Energy, Office of Energy Demand Policy, Final Report of the Interagency Commission on Alternative Motor Fuels, p. 31. \%U.S. Environmental Protection Agency, Office of Mobile Sources, Clean Air Act of 1990 (Washington, DC, January 1991).

"Congressional Research Service, Alternative Transportation Fuels and Clean Gasoline: Background and Regulatory Issues (Washington, DC, March 10, 1994).

"U.S. Department of Energy, Office of Transportation Technologies, Federal Alternative Fuel Program Light Duty Vehicle Operations: Second Annual Report to Congress for Fiscal Year 1992, DOE/EE-0004 (Washington, DC, July 1993), p. 56.
} 


\section{The Clean Air Act Amendments of 1990: Timetable for Implementing Mobile Source Provislons}

1992 Limits on maximum gasoline vapor become law nationwide.

Regulations setting minimum oxygen content for gasoline take effect in 41 areas where carbon monoxide levels exceed national pollution standards.

Enhanced Inspection/Maintenance programs begin in some polluted cities.

1993 Production of vehicles requiring leaded gasoline becomes illegal.

Now standards for sulfur content of diesel fuel take effect, reducing the maximum sulfur level by 80 percent.

1904 Phase-in of tighter tallplpe standards for light-duty vehicles begins.

Phase-in of cold-temperature carbon monoxide standards for light-duty vehicles begins.

Trucks and buses must meet stringent diesel particulate emission standards, equivalent to 5 percent of the uncontrolled level.

Now cars must be equipped with on-board diagnostic systems.

1995 Reformulated gasoline provisions take effect in the Nation's nine smoggiest citles and in many other areas that have "opted-in" to the program.

New warranty provisions on emission control systems take effect.

1988 Phase-in of Califomia Clean Fuels pilot program begins.

Lead is banned from use in motor vehicle fuel. Based on results of an EPA study, regulations limiting vehicle emissions of benzene, formaldehyde, and other harmful air pollutants take effect.

All new vehicles (1996 model year cars and light trucks) must meet new tailpipe and cold-temperature carbon monoxide standards.

1998 Clean-fueled fleets program begins in $0 z 0 n e$ and carbon monoxide nonattainment areas in 22 States.

2001 Second phase of the Fleets and California Pilot clean fuels programs begin.

Note: Moblle sources are vehicle-related.

develop policy, and the Alternative Fuels Council was constituted to advise the Commission. Both entities were decommissioned at the time of their Final Report to the Senate Committees on Commerce, Science, and Transportation and Governmental Affairs and the House Committee on Energy and Commerce (September 1992). ${ }^{99}$ DOE's Office of Alternative Fuels, under the Deputy Assistant Secretary for Transportation Technologies, is responsible for the overall management of the AMFA program. The Alternative Fuels Data Center (AFDC), ${ }^{100}$ which operates in Golden, Colorado, was established to collect information on alternative fuels as a result of this legislation. It is currently collecting data on 800 Federal fleet AFVs, as well as non-Federal AFVs. Additionally, the AFDC collects data on alternative fueled buses and trucks.
Three major AMFA programs were established by DOE in fiscal year 1990 with the assistance of other Federal agencies:

- The Alternative-Fuel Federal Light-Duty Vehicle (LDV) Program (Section 400AA)

- The Truck Commercial Application Program (Section 400BB)

- The Alternative-Fuels Bus Testing Program (Section 400CC).

The objective of the Alternative-Fuel Federal LDV Program is to ensure that the Federal Government annually acquires the maximum practicable number of AFVs (passenger automobiles and other light-duty vehicles)

${ }^{90}$ U.S. Department of Energy, Office of Energy Demand Policy, Final Report of the Interagency Commission on Alternative Motor Fuels, DOE/EP-0002P (Washington, DC, September 1992), p. 19.

${ }^{100}$ Located at the National Renewable Energy Laboratory in Golden, Colorado, the Center's primary purpose is to collect and analyze available data on alternative fuels and all AFV types. 
in fleets. In an Interagency Agreement negotiated between DOE and GSA in fiscal year 1990, Federal fleet vehicles operating on primarily M-85 were procured and placed in four major cities - the District of Columbia, Detroit, Los Angeles, and San Diego. The initial locations were selected in proximity to M-85 refueling facilities. Under a reimbursement program, DOE, on behalf of participating Federal agencies, pays the incremental purchase price difference between the AFV and a comparable traditionally fueled vehicle. The $\$ 7.5$ million program in fiscal year 1993 supported the acquisition of about 6,300 AFVs. The $\$ 18$ million program in fiscal year 1994 will be used in part to help purchase approximately 11,000 AFVs. ${ }^{101}$

The program required a collaborative effort among U.S. vehicle manufacturers, Government agencies, oil companies, and automotive dealerships. After the first year (1991), natural-gas- and ethanol-fueled vehicles were added to the program, and other cities were scheduled for participation.

The objective of the Truck Commercial Application Pro$\mathrm{gram}^{\mathrm{ram}}$ to encourage the use of alternative fuels ${ }^{102}$ by establishing and conducting one or more truck or other heavy-duty vehicle commercial application projects in real-world environments. The program collects data from heavy-duty vehicles operating on alternative fuels to establish emissions, performance, and durability data bases to compare alternative fuels and conventional petroleum-based fuels. DOE is partially funding the required fuels and facilities, fleet operations, the study design, and data management. Other participants include the New York City Department of Sanitation, the Illinois Department of Natural Resources, the California Energy Commission, and the U.S. Postal Service.

Congress established the Alternative Fuels Bus Testing Program as part of the AMFA. The objective of the program is to help State and Federal Government agencies test alternative fueled ${ }^{103}$ buses in urban settings. Information is generated on emissions, durability, and safety and on health, fuel economy, and other issues that industry and fleet operators will need to supply and operate such buses in a commercial environment. Because the DOT is the agency most clearly involved with urban transit buses, it has been assigned the lead role in the program by the Interagency Agreement.
Phase 1 of this program was structured to gain basic information from these demonstrations with a minimum disruption in the normal operation of the participating transit agencies. In addition to this continuing effort, a more focused Phase 2 program has been designed by DOE to gather intensive quantitative data with limited numbers of alternative fueled buses from selected transit authorities.

The use of alternative fueled vehicles in transit has doubled since 1991. Nearly 6 percent of the Nation's fleet of transit buses and vans currently operate on alternative fuels. That share is expected to increase significantly over the next few years. ${ }^{104}$ Several transit authorities, including those in Phoenix, Denver, Los Angeles, and New York City, were selected to gather more detailed operating, maintenance, and emissions data. The data from the transit authorities are transmitted to the AFDC for analysis and dissemination.

\section{Energy Pollcy Act of 1992}

EPACT was designed to meet the energy challenges our Nation faces in the 1990s and 21st century. It was the first major legislative attempt to curb U.S. dependence on foreign oil in over a decade. Its passage touches virtually every sector of the energy industry. Key provisions of the law will: restructure the electric utility industry to promote more competition; provide tax relief to independent oil and gas drillers; encourage energy conservation and efficiency; promote renewable energy and vehicles that run on non-petroleum-based fuels; make it easier to build nuclear power plants; and authorize billions of dollars in energy-related research and development.

EPACT sets a national goal for displacement of 30 percent of the petroleum content of fuels for light-duty motor vehicles (about 2 million barrels per day if defined as gasoline consumed by automobiles) by 2010 with non-petroleum-derived replacement fuels-at least half of which are to come from domestic resources. ${ }^{105}$ The fuels include natural gas, methanol, ethanol, propane, electricity, hydrogen, and other nonpetroleum fuels that may be developed in the future.

The Act requires that, in sequence, the Federal Government, alternative fuel providers (producers, distributors,

\footnotetext{
${ }^{101}$ Presentation at the Interfuel Symposium, Department of Energy, Office of Alternative Fuels (Washington, DC, November 1993).

${ }^{102}$ Originally described for alcohol fuels and natural gas, Section 401(a) of EPACT made all alternative fuels eligible.

${ }^{105}$ Section 402(i) of EPACT expanded the original dual-fueled program to include all alternative fuels.

${ }^{104}$ American Public Transit Association (APTA), Transit News, July 16, 1993.

${ }^{105}$ Congressional Research Service Issue Brief, Alternative Transportation Fuels: Oil Import and Highway Tax Issues (Washington, DC, February 18, 1994).
} 
and marketers), State and local governments, and private fleets buy AFVs in percentages increasing over time to achieve penetration of nonpetroleum fuels in the light-duty vehicle market. Tax incentives for the purchase of AFVs and for the development of retail service stations are provided in the Act. These incentives phase out in 2004.

EPACT empowers the Secretary of Energy to determine by rule that private fleets must purchase AFVs, starting in 1999. The AFV percentage requirement increases from 20 percent in 1999 to 70 percent in 2006 and thereafter. ${ }^{106}$ In order to promote public use of alternative fuels in vehicles, States are encouraged to develop their own programs of economic and regulatory incentives and to apply for Federal financial and technical assistance to implement their programs. The Department of Energy will evaluate the feasibility of aggressive regulatory programs for later years and impose them by rule, if appropriate, based on the result of their studies.

EPACT establishes a broad legislative environment that provides incentives for the use of alternative fuels. The following sections of EPACT refer to alternative fuels:

- Section 405-Public Information Program

- Section 407-Data Acquisition Program

- Section 409-State and Local Incentives Program

- Section 413-Reports to Congress (Inhibitions and Incentives)

- Section 414-Low-Interest Loans

- Section 502b-Replacement Fuel Supply and Demand Programs

- Section 503-Replacement Fuel Supply Estimates and Supply Information

- Section 506-Technical and Policy Analysis

- Section 615(b)-Report on Encouraging the Purchase and Use of Electric Motor Vehicles.

This report focuses on Titles III, IV, and V, with particular emphasis on Section 503. Title III establishes minimum Federal fleet and refueling infrastructure requirements. The intent of this Title is to set program goals for ATFs and AFVs for Federal agencies. Section 301 contains definitions for Titles III, IV, and V where key terms such as alternative fuels, replacement fuels, alternative fueled vehicles (dedicated, dual-fueled, bifueled, and flexible-fueled vehicles) are defined.
Section 303 establishes minimum Federal fleet AFV acquisition requirements for 1993-1995 and percentage requirements for subsequent years (1995-1999 and thereafter). Educational, promotional, and employee incentive programs within the Federal Government associated with AFVs are also included in this Title.

Title IV (non-Federal programs) contains alternative motor fuel amendments to other laws and Executive Orders. It amends the AMFA legislation under the Motor Vehicle Information and Cost Savings Act to include alternative fuels in the CAFE credit program for AFVs. Title IV set up cooperative programs with fuel suppliers and vehicle manufacturers. It also establishes programs for the associated infrastructure that enable the Federal Government to use ATFs and AFVs in fleets. Non-Federal programs, such as State and local incentive programs, alternative fuel bus programs, certification training programs, and low-interest loans are covered in Title IV. A major Section (407) of this Title mandates collection of information for those who are interested in manufacturing, converting, selling, owning, or operating AFVs and alternative fueling facilities. The data collected will consist of demographic information, miles driven, and number of trips made. Additional data on the cost, performance, environment, energy, and safety of AFVs and ATFs are specified to be collected.

Title $V$ establishes goals of displacing 10 percent of total motor fuel usage with alternative fuels by the year 2000 , increasing to 30 percent by 2010 . The Title requires the purchase of AFVs by alternative fuel provider and State fleets. It also requires DOE to evaluate the necessity of requiring private fleets to purchase AFVs in order to meet EPACT motor fuel displacement goals.

While EPACT set national goals for alternative fuel displacement of motor fuels, there are no assurances that alternative fuels will actually be used in private fleets. EPACT defines a dual-fueled vehicle as one that is "capable of operating on alternative fuel and is capable of operating on gasoline or diesel fuel." Under EPACT, Federal and fuel provider fleets must use the alternative fuel if it is available. State and private fleets are subject to AFV purchase requirements but are not required to use the alternative fuel.

Section 503, "Replacement Fuel Demand Estimates and Supply Information," requires EIA to provide estimates to the Secretary of Energy on various aspects of AFV

\footnotetext{
${ }^{100}$ Congressional Research Service, Alternative Transportation Fuels and Clean Gasoline: Background and Regulatory Issues (Washington, DC, March 10, 1994).
} 
and replacement fuel use and to collect related data and information. Specifically, the legislation mandates the following:

- Section 503(a) requires the Secretary of Energy, in consultation with the Administration, the Secretary of Transportation, and other appropriate State and Federal officials, to estimate certain parameters by October 1, 1993 (subsequently extended to October $1,1994)$, and annually thereafter:

(1) The number of each type of alternative fueled vehicle likely to be in use in the United States

(2) The probable geographic distribution of such vehicles

(3) The amount and distribution of each type of replacement fuel

(4) The greenhouse gas emissions likely to result from replacement fuel use.

- Section 503(b) requires that EIA collect information beginning on October 1, 1994 (which was subsequently extended to December 31,1994$)$, and annually thereafter from:

(1) Fuel suppliers in order to report to the Secretary on the amount of each type of replacement fuel that such suppliers:

a. Have supplied in the previous calendar year

b. plan to supply for the following calendar year

(2) suppliers of alternative fueled vehicles in order to report to the Secretary on the number of each type of alternative fueled vehicles that such suppliers:

a. have made available in the previous calendar year

b. plan to make available for the following calendar year

(3) fuel suppliers in order to provide the Secretary information on greenhouse gas emissions from the replacement fuels used, taking into account the entire fuel cycle.

\section{Executive Order 12844: Fedoral Use of Altornative Fuoled Vohicles}

On April 21, 1993, President Clinton signed Executive Order 12844. This Order further established Federal leadership goals for the use of AFVs to reduce pollutants in the atmosphere, create significant domestic economic activity, stimulate job creation, utilize domestic fuel sources, and reduce vehicle maintenance costs. The Order called for Federal action to provide market impetus for the development and manufacture of AFVs and to provide the infrastructure necessary to support large numbers of privately owned AFVs. The Executive Order requires the Federal Government, subject to the availability of funds, to exceed by 50 percent the Federal AFV purchase requirements stated in EPACT. Table 20 compares the requirements of EPACT Title III with those stated in the new Executive Order. ${ }^{107}$

Table 20. Altornative Fueled Vehlolo Tarests for the Foderal Fiect

\begin{tabular}{|c|c|c|}
\hline $\begin{array}{l}\text { Flecal } \\
\text { Year }\end{array}$ & $\begin{array}{c}\text { EPACT } \\
\text { Requirimements }\end{array}$ & $\begin{array}{l}\text { Excouttwo Order } \\
12944\end{array}$ \\
\hline 1993 & 5,000 & 7,500 \\
\hline 1994 & 7,500 & 11,250 \\
\hline 1905 & 10,000 & 15,000 \\
\hline $1906^{\prime}$ & $25 \%$ of acquiaitions & -- \\
\hline $1997^{\prime}$ & $33 \%$ of acquistitions & -- \\
\hline $1998^{\prime}$ & $50 \%$ of acquisitions & -. \\
\hline $1999^{\prime}$ & $75 \%$ of acquisitions & -. \\
\hline
\end{tabular}

'Percentage of acquisitions in these years is based on lightduty vehicle acquisitions. The Executtve Order did not provide AFV targots or percentage of acquiation for these years.

Sources: Energy Pollcy Act of 1992 and Executive Order 12844.

In summary, the legislation discussed augments the Clean Air Act (and subsequent amendments) which set ambient air and vehicle emission standards. AMFA offered incentives to government for the purchase of vehicles that used alternative fuel rather than conventional gasoline by paying differential costs. EPACT further encourages the use of AFVs via motor fuel displacement goals, fleet purchase requirements, alternative fuel and AFV incentives, and supporting ancillary programs. Finally, the commitment by the Clinton Administration to ATFs, AFVs, and an infrastructure to support their use is reflected in Executive Order 12844.

\section{Role of EPA in Regulation of Emissions}

\section{Background}

The CAAA of 1990 set performance standards for fuels, directing EPA to set up standards for attainment of

\footnotetext{
${ }^{10}$ Energy Policy Act of 1992, Public Law 102-486, October 24, 1992; and Executive Order 12844 of April 21, 1993, "Federal Use of Alternative Fueled Vehicles."
} 
CO and ozone levels in various stages or phases within a certain period of time. Progress toward nationwide attainment of ozone ${ }^{100}$ has been slow despite major regulatory and pollution-control programs over the past 20 years. The CAAA were motivated by the extent of nonattainment of air quality in the United States. At the time this legislation was passed, there were still 98 metropolitan areas that failed to meet established standards. However, 1980-1991 ozone data suggest a downward trend in peak ozone values during a period of population and economic growth.

EPA classifies pollution from facilities such as power plants as "stationary" source pollution and transportation-associated pollution as "mobile" source pollution. Emission credit trading under certain circumstances is permitted between mobile and stationary sources. This report discusses only emissions from mobile sources.

Use of alternative and replacement transportation fuels, promoted by EPACT, will be regulated by EPA according to the same baseline emissions standards that apply to conventional fossil-based transportation fuels, such as gasoline and diesel fuel. Although many of the operational and environmental characteristics of alternative fuels have been studied, EPA is developing a strategy intended to further identify critical research areas. Further assessment of the health and environmental risks and benefits associated with alternative fuels is necessary.

\section{Moblle Source Emissions}

Mobile sources contribute about half of total airborne emissions in urban areas. ${ }^{109}$ Conventional gasoline is a major source of urban air pollution due to both the products of its combustion (exhaust) and evaporation. Evaporative emissions are emissions from spillage, leaking vehicle canisters, and fueling operations. Conventional gasoline is responsible for most of the mobilesource-generated hydrocarbons, or VOCs. Other exhaust emissions include $\mathrm{NO}_{x}$ and $\mathrm{CO}$. Methane emissions are exempt from regulations. The CAAA do not mandate the use of nonpetroleum fuels, but do require programs to reduce emissions. Strategies to reduce emissions include a program which requires (1) the use of oxygenated gasoline and (2) reformulation of gasoline to reduce harmful compounds and aromatics that cause emissions.

\section{Vohicular Emiselons 8tandarde}

EPA has developed vehicle emisoion standards to reduce the amount of mobile source pollutants. Historically, different standards have been set for different classes of vehicles, taking into account such factors as engine type, fuel flow rates, and power requirements. California developed a stringent program in response to Its status as the State with the worst pollution problems; this program has received approval by EPA. The California standards are, in most cases, more stringent than the national standard.

EPA has completed the development of Tier I emission standards, designed to reduce the level of pollutants from cars and trucks. Tier I covers currently regulated pollutants $\left(\mathrm{CO}, \mathrm{NO}_{\mathrm{x}}\right.$, particulate matter) as well as hydrocarbon standards determined on a nonmethane basis (Table 21). Tier I emission standards begin phasein in 1994 and continue indefinitely. EPA will conduct a study to determine the need to implement stricter Tier II standards. If adopted, Tier II would take effect beginning in 2003.

Oxygenated fuels appear to have substantially reduced ambient levels of $\mathrm{CO}$ in most of the nonattainment areas during the winter of 1992-93. To help reduce smog in urban areas, the CAAA authorized EPA to develop regulations for cleaner, reformulated gasoline. These rules, which have recently been finalized, establish Phase I RFG standards for the years 1995-1999 and Phase II RFG standards for the years 2000 and thereafter. While the rules require specific composition changes in gasoline (described later in this report), Phase I fuel must achieve a 15-percent reduction in VOCs and harmful air pollutants, while Phase II must achieve a 25-percent reduction.

Currently, there is no EPA year-round regulation for oxygen content in conventional gasoline. However, during the winter months, as a measure to reduce $\mathrm{CO}$ in nonattainment areas, oxygen content must be at least 2.7 percent by weight (except in California, which has a 2-percent minimum waiver from EPA). Although EPA does not regulate benzene, the American Society for Testing Materials (ASTM) currently considers 1.5- to 2percent (volume) benzene content in gasoline as an industry standard. Reformulated gasoline holds considerable promise for meeting the California/Phase II

\footnotetext{
${ }^{100}$ Ozone continues to be the most pervasive problem of the six major air pollutants for which the NAAQS have been designated under the Clean Air Act.

${ }^{100}$ U.S. Environmental Protection Agency, Office of Air Quality Planning and Standards, National Air Quality and Emissions Trends Report, 1991, p. 1-5.
} 
Table 21. Emlealons standarde for Llght-Duty Vohlolee (Orams por Milo)

\begin{tabular}{|c|c|c|c|c|c|c|c|}
\hline \multirow[b]{2}{*}{ Standard } & \multirow[b]{2}{*}{ Perlod } & \multicolumn{2}{|c|}{$\begin{array}{l}\text { Nonmothane } \\
\text { Hydrocarbone }\end{array}$} & \multicolumn{2}{|c|}{$\begin{array}{c}\text { Carbon } \\
\text { Monoxlde }\end{array}$} & \multicolumn{2}{|c|}{$\begin{array}{c}\text { Nitrogen } \\
\text { Oxidee }\end{array}$} \\
\hline & & 8-year' & 10-year & 5-year' & 10-year & 5-yoar' & 10-ycar \\
\hline Ther $1 \ldots \ldots \ldots$ & $1994 t^{3}$ & 0.125 & 0.31 & 3.4 & 4.2 & 0.4 & 0.6 \\
\hline Ther $\| \ldots \ldots \ldots$ & $2003+$ & 0.075 & 0.128 & 3.4 & 1.7 & 0.2 & 0.2 \\
\hline
\end{tabular}

'Standards based on a 5-year, 50,000-mile usoful Ifte.

'Standarda besed on a 10-year, 100,000-mile useful life.

Tier I emiselons standards begin phaso-in in 1994 and continue indefinitely. If a study by EPA determines the need to implement more stringent emiselon standards, the Tier II phase-in will begin in 2003 and replace the prior standards.

Note: These standards may be superseded by Caliomia standards if the latter are found to be as stringent, in the aggregate, by EPA.

Source: U.S. Environmental Protection Agency, Office of Moblle Sources.

standards. Industry tests indicate that RFG can reduce $\mathrm{CO}$ emissions by about 35 percent, $\mathrm{NO}_{x}$ by 26 percent, and total hydrocarbons by 37 percent over industryaveraged gasoline. ${ }^{110}$

\section{Clean-Fuel Fleot Program}

According to the CAAA, the goals of the Clean-Fuel Fleet Program are to reduce ozone precursors, such as nonmethane hydrocarbon and $\mathrm{NO}_{\mathrm{x}}$ emissions, and to commercialize clean-fuel vehicles in centrally fueled fleets. Beginning in 1998, 30 percent of new vehicles purchased by centrally fueled fleets in certain nonattainment areas will be required to use clean fuels and meet the tailpipe standards (useful life of 5 years or 50,000 miles) ${ }^{111}$ of $0.075 \mathrm{gpm}$ hydrocarbons, $3.4 \mathrm{gpm}$ $\mathrm{CO}$, and $0.2 \mathrm{gpm} \mathrm{NO}$. These standards are more stringent than those currently in place for 1994 general passenger cars. The requirement will increase to 70 percent of all fleet vehicles by 2000 . The program, which is intended to stimulate development of new, low-polluting fuel/vehicle combinations, will affect 19 States and 22 designated high-pollution geographic areas.

\section{Inspection and Maintenance Programs}

The CAAA impose rigorous air quality standards, which focus on mobile (motor vehicles) and stationary sources. Motor vehicles have been identified as a major source of urban air pollution. Vehicle Inspection and
Maintenance $(\mathrm{I} / \mathrm{M})$ programs (mandated in the CAAA legislation) have been identified as one of the pivotal strategies for achieving these new emission standards. EPA has the primary role of issuing guidelines and approving $\mathrm{I} / \mathrm{M}$ programs that State and local agencies have designated in their State Implementation Plans (SIPs). These plans establish emission parameters and $1 / \mathrm{M}$ programs. Emission standards will apply to nearly all mobile sources. The rules affect fleets first, and in time, the general public. There will be no differentiation between Federal and non-Federal fleets in the new I/M requirements. Standards that apply to private-sector fleets are equally applicable to Federal fleets.

$\mathrm{I} / \mathrm{M}$ programs are required in both ozone and $\mathrm{CO}$ nonattainment areas. The requirement for either a "basic" or "enhanced" program varies according to nonattainment classification (e.g., "severe"). According to $E P A,{ }^{112}$ the requirement for $I / M$ will apply in 182 urban areas, containing approximately one of every two light-duty vehicles in the Nation. In addition, Ozone Transport Regions (OTRs), such as the one that extends from Maine to Northern Virginia, have been established to address the phenomenon of ozone and/or its precursors being transported to another area, degrading air quality in the downwind location. All MSAs within the OTRs with populations of 100,000 or greater are required to have $\mathrm{I} / \mathrm{M}$ programs. The programs in these areas with a population greater than 200,000 must be "enhanced."113 Some CMSAs are also included.

\footnotetext{
${ }^{110}$ Auto/Oil Program.

"'For a useful life, 10 years or 100,000 miles, the tailpipe standards are: $0.31 \mathrm{gpm}$ hydrocarbons, $4.2 \mathrm{gpm} \mathrm{CO,} \mathrm{and} 0.6 \mathrm{gpm} \mathrm{NO}$.

${ }^{112}$ U.S. Environmental Protection Agency, Office of Mobile Sources, Presentation by Jane Armstrong (Washington, DC, April 1993).

${ }^{113}$ Enhanced I/M programs are required in all serious, severe, and extreme ozone areas, plus all $\mathrm{CO}$ areas greater than $12.7 \mathrm{ppm}$, plus all MSAs of 100,000 or more population in the Northeast Transportation Region. Basic I/M programs are required in all moderate ozone nonattainment areas.
} 


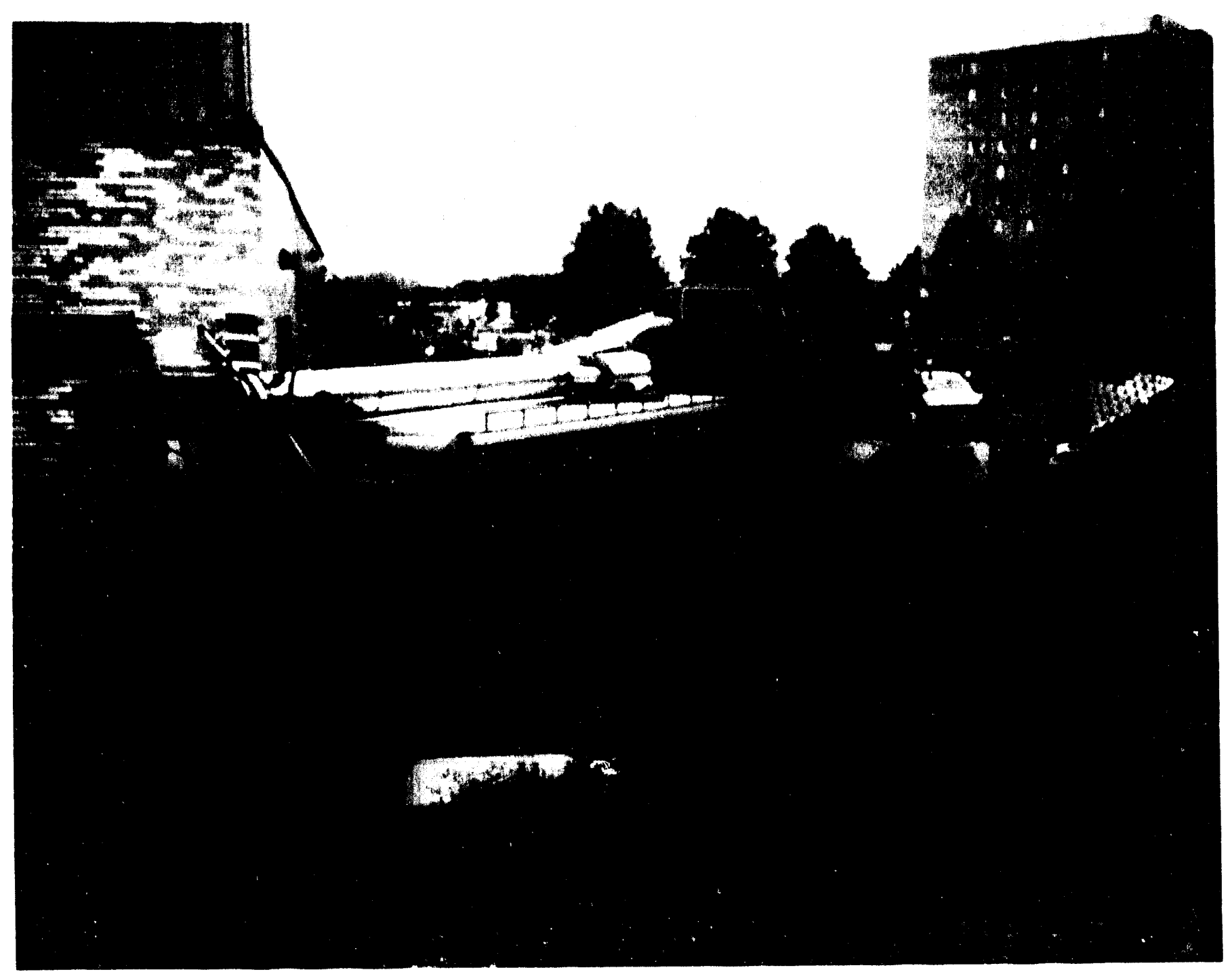

At this mobile emissions test facility, tailpipe emissions from a school bus are being analyzed.

Whether an area has a basic or an enhanced I/M program depends upon the severity of its pollution problem. In less serious areas, basic $\mathrm{I} / \mathrm{M}$ programs are required. Moderate ozone nonattainment areas must have at least a basic program in place. With basic programs, more flexibility in program design and operation is allowed. These areas have the option of choosing between test-only and test-and-repair facilities, and only need to run simple idle tests. If they so choose, areas with basic programs may opt into an enhanced program as a means of offsetting emissions from stationary industrial sources.

In contrast, no self-testing is allowed in enhanced areas and no license for testing will be dispensed to stations that provide maintenance and repair services. Because the CAAA require test-only facilities in enhanced $I / M$ areas, the most common type of operation likely to be put into place will be a centralized, contractor-operated, test-only facility.
In accordance with the CAAA, Federal agencies are required to comply with State and local air pollution laws and regulations. Cooperation among Federal, State, and local agencies is encouraged for fleet testing by Statecertified contractors. All Federal vehicles, with the exception of military tactical vehicles designed or converted for use in combat, and vehicles of Federal employees must comply with the $\mathrm{I} / \mathrm{M}$ requirements. Fleet vehicles must go through the same testing procedure as other vehicles.

Enhanced I/M tests attempt to mimic a typical driving pattern, perform an evaporative purge, and check the integrity of the evaporative system. The procedure used for enhanced $\mathrm{I} / \mathrm{M}$ is called a "transient loaded test with mass emissions." Vehicles are driven over a dynamometer to simulate actual driving conditions. Emissions are collected, measured, and a reading in $\mathrm{gpm}$ of pollutant is presented. 
Implementation of basic $\mathrm{I} / \mathrm{M}$ programs to be carried out by private garages was scheduled to begin in January 1994. In July 1994, programs to be carried out by centralized facilities will begin. Enhanced I/M programs are scheduled to start in January 1995 and be fully implemented by January of the following year.

\section{Role of States in Regulation of Emissions}

\section{State Implementation Plans}

Ozone nonattainment areas consist of MSAs, CMSAs, and counties. The CAAA require that a State Implementation Plan (SIP) be developed which will reduce precursor emissions enough to bring air quality into compliance with NAAQS. A SIP is developed by the State and/or nonattainment area and then approved or disapproved by EPA. Once the plan is fully approved, it is legally binding under both State and Federal law. ${ }^{114}$ Performance under the SIP is monitored by EPA, and a new SIP must be submitted and approved.

The major components of air pollution have been identified, and maximum levels for each have been established as part of the EPA guidelines for the States in development of their programs. Most of the planning, control strategy development, implementation, and process are based on the ozone design values for specific metropolitan areas. The SIP is submitted in stages, with the first revisions designed to partially reduce ozone precursors and to enact programs like I/M. The final SIP revision is due by November 15, 1994. This revision includes all regulations necessary to attain the air quality standards. However, all programs may not be fully implemented until $1996 .{ }^{115}$ Plans will rely on monitoring of ozone, $\mathrm{NO}_{\mathbf{x}}$ and VOCs for the demonstration of attainment and maintenance of the NAAQS in all ozone areas. The demonstration phase of a plan will take 1 to 4 years after the plan begins, depending on the classification of the area. Once an area attains the applicable standards, the CAAA require areas to submit an approvable plan to show how the area will "maintain" its attainment status over a 10-year period. If States do not submit approvable plans by the schedule contained in the Act, EPA may impose a Federal Implementation Plan (FIP) for the area. The FIP could be a complete replacement of the State plan or a supplement to correct its deficiencies.

Some States, such as California, have extremely serious mobile-source air quality problems. As a result, they have adopted more stringent maximum allowable pollutant limits than most other areas of the country. The California SIP has received national attention because of its rigorous standards, which are enforced by the California Air Resources Board (CARB). In some cases, the CARB standards exceed EPA mobile-source standards. For this reason, some other States in severe NAAQS nonattainment status also wish to adopt CARB standards.

\section{Callfornia Programs}

The CAAA directed EPA to implement the California Pilot Program. The State responded by additionally implementing its own LEV Program. The goals of both programs are to reduce ozone precursors; to reduce harmful emissions such as nonmethane organic gases (NMOGs); to demonstrate clean fuels technology in a large, visible statewide program; and to support California's clean fuels initiatives.

The Pilot Program sets lower hydrocarbon emissions standards for the production and sale of clean-fueled fleet vehicles in that State beginning with the 1996 model year. The sales requirement is 150,000 vehicles per year in 1996 through 1998, and 300,000 vehicles per year after that. ${ }^{116}$ In 2003, the Phase II standards for NMOG, $\mathrm{CO}$, and $\mathrm{NO}_{x}$ may be implemented (Table 21), bringing the standard still lower. RFG is expected to be able to meet this lower standard. By the year 2010, an estimated 2 million clean-fueled fleet vehicles will be in operation due to sales requirements. ${ }^{17} \mathrm{~A}$ clean fuels availability program is included in the California SIP. ${ }^{118}$ Other States with serious, severe, or extreme ozone nonattainment areas may voluntarily opt-in to the California program.

\footnotetext{
${ }^{114}$ National Research Council, Committee on Tropospheric Ozone Formation and Measurement, Rethinking the Ozone Problem in Urban and Regional Air Pollution (Washington, DC: National Academy Press, 1991).

${ }^{115}$ Interagency briefing by EPA at the General Services Administration (Washington, DC, April 21, 1993).

${ }^{116}$ U.S. Environmental Protection Agency, Office of Mobile Sources, presented at the 1993 National Alternative Fuels Conference (Milwaukee, Wl, June 28, 1993).

${ }^{117}$ U.S. Environmental Protection Agency, Office of Mobile Sources, presented at the 1993 National Alternative Fuels Conference (Milwaukee, WI, June 28, 1993).

${ }^{118}$ California must adopt a program to assure fuel availability. If it does not, EPA must.
} 
The LEV Program requires more clean-fuel vehicles than the Pilot Program. Under the LEV Program requirements, sales are expected to increase by 200 percent in 1996 and 400 percent in 1999, as compared with the Pilot Program. ${ }^{19}$ Manufacturers will receive LEV Program credits for lower fleet average NMOG emissions, sale of more clean-fuel vehicles, and sale of cleaner vehicles than required. Averaging, trading, and banking of credits is permitted. The amount of fuel and type of fuel depends on the type of vehicle sold. The LEV program requires a minimum of 20,000 vehicles to be sold, with a supporting provision mandating at least
90 service stations. LEV Program clean-fuel vehicle emissions standards are to control the pollutants NMOG, CO, NO, $\mathrm{PM}-10$, and formaldehyde (HCHO) according to four vehicle emissions standards. They are, in order of decreasing emissions: transitional lowemission vehicle (TLEV), low-emission vehicle (LEV), ultra-low-emission vehicle (ULEV), and zero-emission vehicle (ZEV). TLEV standards match the CAAA Phase I (1996) and LEV standards match the CAAA Phase II (2003) for light-duty vehicles; for medium-duty vehicles, the LEV standards match CAAA for a light-duty truck classification (1998).

${ }^{11}$ U.S. Environmental Protection Agency, Office of Mobile Sources, presented at the 1993 National Alternative Fuels Conference (Milwaukee, WI, June 28, 1993). 


\section{Alternative Fuels}

\section{Introduction}

The alternative fuels defined in EPACT are important because of their potential ability to both improve the environment and reduce U.S. dependence on imported petroleum. The fuels identified include two alcoholsethanol (but not as used in gasohol) and methanol; three fuels that are gases at normal temperature and pressures-liquefied petroleum gas (LPG), natural gas, and hydrogen; and electricity. In addition, EPACT recognized that alternative feedstocks such as biomass or the large U.S. coal base could assist in reducing U.S. dependence on petroleum. Thus, coal-derived liquid fuels, fuels other than alcohol derived from biological materials, and other fuel that the Secretary of Energy determines, by rule, is substantially not petroleum could qualify as alternative fuels under EPACT.

Before proceeding with a detailed description of the composition and physical characteristics of the fuels, a brief overview of each fuel is covered below for those readers unfamiliar with alternative fuels. The overview highlights the main constituents of the fuel, its uses in other markets, and some of the advantages or disadvantages the material presents as a highway fuel. These characteristics are discussed in more detail in the later sections of the chapter.

\section{Hydrogen}

Hydrogen gas $\left(\mathrm{H}_{2}\right)$ is being explored for use in combustion engines and fuel-cell electric vehicles. It is a gas at normal temperatures and pressures, which presents greater transportation and storage hurdles than exist for the liquid fuels. Storage systems being developed include compressed hydrogen, liquid hydrogen, and chemical bonding between hydrogen and a storage material (for example, metal hydrides). Hythane, a combination of 15 percent hydrogen and 85 percent natural gas, is being tested in metal lattice storage systems.

While no transportation distribution system currently exists for hydrogen transportation use, the ability to create the fuel from a variety of resources and its cleanburning properties make it desirable as an alternative fuel. Of the alternative fueled vehicles covered in this report, hydrogen-powered vehicles are probably the furthest from commercialization. Hydrogen vehicles will probably not present a feasible, cost-effective option until well past the year $2000{ }^{120}$

\section{Compressed Natural Gas and Liquefled Natural Gas}

Natural gas is a mixture of hydrocarbons-mainly methane $\left(\mathrm{CH}_{4}\right)$-and is produced either from gas wells or in conjunction with crude oil production. Natural gas is consumed in the residential, commercial, industrial, and utility markets. The existing distribution system brings natural gas to 51.6 million residential consumers, 4.4 million commercial consumers, and 0.2 million industrial establishments. ${ }^{121}$ Natural gas has played a minor role historically in the U.S. transportation market. As a gas, it is more difficult to store than liquid product. Natural gas is delivered continuously through a gas pipeline network in the United States to end users.

The interest in natural gas as an alternative fuel stems mainly from its clean burning qualities, its domestic resource base, and its commercial availability to end users. Because of the gaseous nature of this fuel, it must be stored onboard a vehicle in either a compressed gaseous state (CNG) or in a liquefied state (LNG). Natural gas is liquefied at reduced temperatures and contained in this state in insulated, pressurized tanks.

\section{Liquefied Petroleum Gas}

Liquefied petroleum gas consists mainly of propane, propylene, butane, and butylene in various mixtures. However, for all fuels in the United States, the mixture is mainly propane. It is produced as a byproduct of natural gas processing and petroleum refining. Propane or LPG is used in all major end-use sectors as a heating fuel, engine fuel, cooking fuel, and chemical feedstock.

\footnotetext{
${ }^{120}$ Michael Williams, "Mazda Takes Journalists for a Jaunt in Hydrogen-Powered Automobile," Wall Street Journal, October 25, 1993, p. B5E.

${ }^{121}$ Energy Information Administration, Natural Gas Annual 1992, DOE/EIA-0131(92), Table 17.
} 
The components of LPG are gases at normal temperatures and pressures. With moderate pressure (100 to $300 \mathrm{psi}$ ), they condense to liquids, making them easy to store and transport. As such, LPG has many of the storage and transportation advantages of liquids, along with the fuel advantages of gases. LPG was in relatively widespread automotive use (mainly fleets) prior to the enactment of EPACT.

\section{Methanol}

Methanol $\left(\mathrm{CH}_{3} \mathrm{OH}\right)$ and ethanol $\left(\mathrm{C}_{2} \mathrm{H}_{5} \mathrm{OH}\right)$ are both alcohol fuels. Today, most of the world's methanol is produced by a process using natural gas as a feedstock. However, the ability to produce methanol from nonpetroleum feedstocks such as coal or biomass is of interest for reducing petroleum imports.

The alternative methanol fuel currently being used is M-85. In the future, neat methanol, or M-100, may also be used. Methanol is also made into an ether, MTBE, which is blended with gasoline to enhance octane and to create oxygenated gasoline.

\section{Ethanol}

Ethanol in the United States is produced mainly by a cooking and fermenting process using grain crops, with corn being the primary feedstock. The main use of ethanol is for gasohol (a blend of 90 percent unleaded gasoline and 10 percent ethanol) and for lower blends of ethanol to meet oxygenated gasoline requirements. Ethanol used in gasohol and other oxygenated gasoline

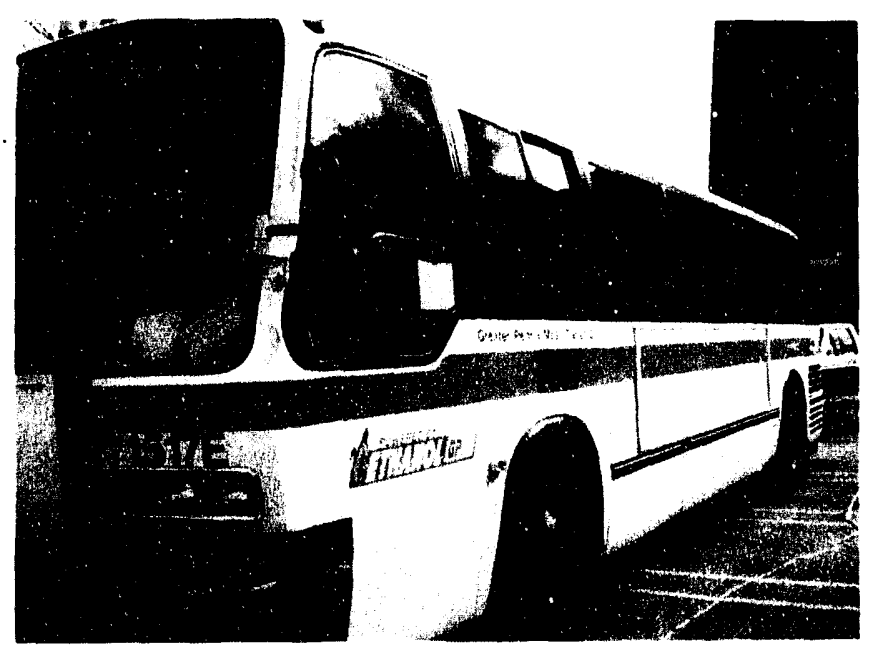

An ethanol-powered transit bus in Peoria, Illinois. blends meets the definition of a replacement fuel, but not of an alternative fuel.

Two higher blends of ethanol, E-85 and E-95 are being explored as alternative fuels in demonstration programs. Ethanol is also made into an ether, ethyl tertiary-butyl ether (ETBE), that has properties of interest for oxygenated gasoline and reformulated fuels. (See oxygenated and reformulated gasoline sections of Chapter 7.) As in the case of methanol, E-85 is the primary ethanol alternative fuel currently being considered.

\section{Electricity}

Electricity is unique among the alternative fuels in that mechanical power is derived directly from it, whereas the other alternative fuels release stored chemical energy through combustion to provide mechanical power. Motive power is produced from electricity by an electric motor, whereas it is produced by an internal combustion engine in the case of the other alternative fuels. Electricity in vehicles is commonly provided by batteries, but fuel cells are also being explored. Batteries are the storage "tanks" for electricity, and the quantity of potential power available from them is given by the battery rating (determined by plate size, quantity of electrolyte, etc.). Unlike batteries, fuel cells do not store energy but rather convert chemical energy to electricity. An external source of hydrogen ${ }^{122}$ and oxygen (from air) are fed to the fuel cell. The electrolyte fuel cells employ the electrochemical reaction between hydrogen and oxygen to generate electricity. This section focuses only on battery-powered electric vehicles because fuelcell electric vehicles are a longer term option.

\section{Physical and Chemical Characteristics}

\section{Overview}

The primary alterrative fuels characteristics that $a^{f}{ }^{f} e c t$ combustion engine performance are described below. These characteristics explain the major differences and similarities among the fuels (Table 22).

Most of the physical and chemical characteristics discussed in this section are for internal combustion engine performance. In an internal combustion engine, energy to power the vehicle derives from fuel com-

\footnotetext{
${ }^{122}$ Pure hydrogen can be stored in the vehicle for use in fuel cells, or hydrogen can be produced by reforming a simple hydrocarbon fuel stored in the vehicle.
} 


\section{Table 22. Properties of Fuels}

\begin{tabular}{|c|c|c|c|c|c|c|c|c|}
\hline Proporty & Gasoline & $\begin{array}{c}\text { No. } 2 \\
\text { Dheol Fual }\end{array}$ & Mothanol & Ethand & MTBE & Propane & $\begin{array}{c}\text { CNe } \\
\text { (Mothen) }\end{array}$ & Hydrogen \\
\hline Chernical Formula . & $C_{4}$ to $C_{12}$ & $C_{3}$ to $C_{25}$ & $\mathrm{CH}_{3} \mathrm{OH}$ & $\mathrm{C}_{2} \mathrm{H}_{5} \mathrm{OH}$ & $\left(\mathrm{CH}_{3}\right)_{3} \mathrm{COCH}_{3}$ & $\mathrm{C}_{3} \mathrm{H}_{6}$ & $\mathrm{CH}_{4}$ & $\mathbf{H}_{2}$ \\
\hline Molecular Weight $\ldots \ldots \ldots \ldots \ldots$ & $100-105^{(1)}$ & 200 (approx.) & 32.04 & 46.07 & 88.15 & 44.1 & 16.04 & $2.02^{(x)}$ \\
\hline \multicolumn{9}{|l|}{ Composition, Weight \% } \\
\hline Carbon & $85-88^{(b)}$ & 84-87 & 37.5 & 52.2 & 68.1 & 82 & 75 & 0 \\
\hline Hydrogen $\ldots \ldots \ldots \ldots \ldots \ldots$ & $12-15^{(D)}$ & $33-16$ & 12.6 & 13.1 & 13.7 & 18 & 25 & 100 \\
\hline Oxygen $\ldots \ldots \ldots \ldots \ldots \ldots$ & 0 & 0 & 49.9 & 34.7 & 18.2 & - & - & 0 \\
\hline Specific gravity, $60^{\circ} \mathrm{F} / 60^{\circ} \mathrm{F} \ldots \ldots$ & $0.72-0.78^{(b)}$ & $0.81-0.89^{(0)}$ & $0.796^{(c)}$ & $0.796^{(c)}$ & $0.744^{(m)}$ & 0.508 & 0.424 & $0.07^{(u)}$ \\
\hline Density, th/gal $\bullet 60^{\circ} \mathrm{F} \ldots \ldots \ldots$ & $6.0-6.5^{(b)}$ & $6.7-7.4^{(0)}$ & $6.63^{(b)}$ & $6.61^{(b)}$ & $6.19^{(m)}$ & 4.22 & $1.07^{(n)}$ & - \\
\hline Boiling temperature, ${ }^{\circ} \mathbf{F}$. & $80-437^{(0)}$ & $370-650^{(d)}$ & $149^{(c)}$ & $172^{(c)}$ & $131^{(c)}$ & -44 & -259 & $-4,230^{(u)}$ \\
\hline Reid vapor pressure, psi & $8-15^{(k)}$ & 0.2 & $4.6^{(0)}$ & $2.3^{(0)}$ & $7.8^{(0)}$ & 208 & 2,400 & - \\
\hline \multicolumn{9}{|l|}{ Octane no. ${ }^{(1)}$} \\
\hline Research octane no. ......... & $90-100^{(u)}$ & - & 107 & 108 & $116^{(1)}$ & 112 & - & $130+$ \\
\hline Motor octane no. ............. & $81-90^{(8)}$ & - & 92 & 92 & $101^{(1)}$ & 97 & - & - \\
\hline$(R+M) / 2 \ldots \ldots \ldots$ & $86-94^{(8)}$ & NA & 100 & 100 & $108^{(t)}$ & 104 & $120+$ & - \\
\hline Cetane no. ${ }^{(1)} \ldots \ldots \ldots \ldots \ldots$ & $5-20$ & $40-55$ & - & - & - & - & - & - \\
\hline \multicolumn{9}{|l|}{ Water solubility, $70^{\circ} \mathrm{F}$} \\
\hline Fuel in water, volume $\% \quad \ldots \ldots$ & Negligible & Negligible & $100^{(c)}$ & $100^{(\mathrm{b})}$ & $4.3^{(0)}$ & - & - & - \\
\hline Water in fuel, volume $\%, \ldots \ldots$ & Negligible & Negligible & $100^{(c)}$ & $100^{(b)}$ & $1.4^{(0)}$ & - & - & - \\
\hline Freezing point, ${ }^{\circ} \mathrm{F} \ldots \ldots \ldots \ldots$ & $-40^{(0)}$ & $-40-30^{(4)}$ & -143.5 & -173.2 & $-164^{(c)}$ & -305.8 & -296 & $-435^{(v)}$ \\
\hline \multicolumn{9}{|l|}{ Viscosity } \\
\hline Centipoise $\odot 68^{\circ} \mathrm{F} \ldots$ & $0.37-0.44^{(3 . p)}$ & $2.6-4.1$ & $0.59^{(i)}$ & $1.19^{(1)}$ & $0.35^{(1)}$ & - & - & - \\
\hline Flash point, closed cup, ${ }^{\circ} \mathrm{F} . \ldots \ldots$ & $-45^{(b)}$ & $165^{(d)}$ & $52^{(0)}$ & $55^{(0)}$ & $-14^{(e)}$ & -100 to -150 & -300 & - \\
\hline Autoignition temperature, ${ }^{\circ} \mathrm{F} \ldots \ldots$ & $495^{(b)}$ & 600 (approx.) & $867^{(b)}$ & $793^{(b)}$ & $815^{(0)}$ & $850-950$ & 1,004 & $1,050-1,080^{(u)}$ \\
\hline \multicolumn{9}{|l|}{ Flammability limits, volume $\%$} \\
\hline Lower...$\ldots \ldots \ldots$ & $1.4^{(b)}$ & 1 & $7.3^{(0)}$ & $4.3^{(0)}$ & $1.6^{(0, k)}$ & 2.2 & 5.3 & $4.1^{(u)}$ \\
\hline Higher $\ldots \ldots \ldots \ldots \ldots$ & $7.6^{(b)}$ & 6 & $36^{(0)}$ & $19^{(0)}$ & $8.4^{(0 . k)}$ & 9.5 & 15 & $74^{(u)}$ \\
\hline
\end{tabular}

See footnotes at end of table. 
Table 22. Properties of Fuels (Continued)

\begin{tabular}{|c|c|c|c|c|c|c|c|c|}
\hline Property & Gasoline & $\begin{array}{l}\text { No. } 2 \\
\text { Diecel Fuel }\end{array}$ & Mothanol & Ethanol & MTBE & Propans & $\begin{array}{c}\text { Crve } \\
\text { (Wetheno) }\end{array}$ & Hydrogen \\
\hline \multicolumn{9}{|l|}{ Latent heat of vaporization } \\
\hline Btwgal $60^{\circ} \mathrm{F}$ & 900 (approx.) $)^{(1)}$ & 700 (approx.) & $3340^{(0)}$ & $2378^{(0)}$ & $863^{(5)}$ & 775 & - & - \\
\hline Btulib $\bullet 60^{\circ} \mathrm{F} \ldots$ & 150 (approx.) $)^{(0)}$ & 100 (approx.) & $506^{(b)}$ & $396^{(0)}$ & $138^{(5)}$ & 193.1 & 219 & $192.1^{(n)}$ \\
\hline $\begin{array}{l}\text { Btunb air for stoichiometric mixture } \\
\text { - } \mathbf{0}^{\circ} \mathrm{F} \ldots \ldots \ldots \ldots \ldots \ldots\end{array}$ & 10 (approx. $^{(1)}$ & 8 (approx.) & $78.4^{(0)}$ & $44^{(0)}$ & 11.8 & - & - & - \\
\hline \multicolumn{9}{|l|}{ Heating value ${ }^{(2)}$} \\
\hline $\begin{array}{l}\text { Higher (liquid fuetliquid water) } \\
\text { Btulb } \ldots \ldots \ldots \ldots \ldots \ldots \ldots\end{array}$ & $18,800-20,400$ & $19,200-20,000$ & $9,750^{(2)}$ & $12,800^{(\Phi)}$ & $18,290^{(n)}$ & 21,600 & 23,600 & $61,002^{(n)}$ \\
\hline $\begin{array}{l}\text { Lower (liquid fuet-water vapor) } \\
\text { Btulb } \ldots \ldots \ldots \ldots \ldots \ldots \ldots\end{array}$ & $18,000-19,000$ & $18,000-19,000$ & $8,570^{(b)}$ & $11,500^{(9)}$ & $15,100^{(n)}$ & 19,800 & 21,300 & $51,532^{(v)}$ \\
\hline $\begin{array}{l}\text { Higher (liquid fuel-liquid water) } \\
\text { Btwgal ................ }\end{array}$ & 124,800 & 138,700 & 64,250 & 84,100 & - & 91,300 & - & - \\
\hline $\begin{array}{l}\text { Lower (liquid fuel-water vapor) } \\
\text { Btwgal } \bullet 60^{\circ} \mathrm{F} \ldots \ldots \ldots \ldots\end{array}$ & 115,000 & 128,400 & $56,800^{(3)}$ & $76.000^{(3)}$ & $93,500^{(4)}$ & 84,500 & $19,800^{(0)}$ & - \\
\hline \multicolumn{9}{|l|}{ Heating value, stoichiometric mixture } \\
\hline $\begin{array}{l}\text { Mixture in vapor state, } \\
\text { Btu/cubic foot } \odot 68^{\circ} \mathrm{F} \ldots \ldots \ldots\end{array}$ & $95.2^{(b)}$ & $96.9^{(5.9)}$ & $92.5^{(b)}$ & $92.9^{(0)}$ & - & - & - & - \\
\hline Fuel in liquid state, Btulb or air ... & $1,290^{(b)}$ & - & $1,330^{(\mathfrak{b})}$ & $1,280^{(b)}$ & - & - & - & - \\
\hline Specific heat, Btulb of $\ldots \ldots \ldots$ & $0.48^{(9)}$ & 0.43 & $0.6^{(1)}$ & $0.57^{(1)}$ & $0.5^{(1)}$ & - & - & - \\
\hline Stoichiometric airfuel, weight $\ldots .$. & $14.7^{(3 ;}$ & 14.7 & $6.45^{(1)}$ & $9^{(1)}$ & $11.7^{(1)}$ & 15.7 & 17.2 & $34.3^{(u)}$ \\
\hline $\begin{array}{l}\text { Volume \% fuel in vaporized } \\
\text { stoichiometric mixture ..... }\end{array}$ & $2^{(\text {(b) }}$ & - & $12.3^{(0)}$ & $6.5^{(0)}$ & $2.7^{(1)}$ & - & - & - \\
\hline
\end{tabular}

Notes:
(1)

(1) Octane values are for pure components. Laboratory engine Research and Motor octane rating procedures are not suitable for use with neat oxygenates. Octane values obtained by these methods are not useful in determining knock-limited compression ratios for vehicles

when blended with hydrocarbons. Similar problems exist for cetane rating procedures.

moisture of combustion, the lower heating value should be used for practical comparisons between fuels.

(3)Calculated.

(4)Pour Point, ASTM D 97 from Reference (c).

(5) Based on cetane.

(6) For compressed gas at 2,400 psi. 


\section{Table 22. Properties of Fuels (Continued)}

Sources:

(a) The basis of this table and associated references was taken from: American Petroleum Institute, Akohols and Ethers, Publication No. 4261, 2nd ed. Washington, DC, July 1988), Table B-1.

(b)-Alcohols: A Technical Assessment of Their Application as Motor Fuels," API Publication No. 4261, July 1976.

(c) Hanctork of Chemistry and Physics, 62nd Edition, 1981, The Chemical Rubber Company Press, Inc.

(1) Diesel Fuel Oils, 1987." Petroleum Product Suneys, National Institute for Petroleum and Energy Reseerch, October 1987.

(1)ARCO Chemical Company, 1987.

(D)MTBE, Evaluation as a High Octane Blending Component for Unleaded Gasoline," Johnson. R.T., Taniguchi, B.Y., Symposium on Octane in the 1980's, American Chemical Society, Miami Beach Meeting. September 10-15, 1979.

(a)m-Status of Alcohol Fuels Utilization Technology for Highway Transportation: A 1981 Perspective," Vol. 1, Spark-lgnition Engine, May 1982, DOE/CE-56051-7.

(in) American Petroleum Institute Research Project 44, NBS C-461.

(i) Lang's Handbook of Chemistry, 13th Edition, McGraw-Hill Book Company, New York, 1985.

(1)

(1) Petroleum Product Surveys, Motor Gasoline, Summer 1986, Winter 1986/1987, National Institute for Petroleum and Energy Research.

(1)Based on isoctane.

(m)API Monograph Series, Publication 723, "Teri-Butyl Methyl Ether," 1984.

(n) BP America, Sonio Oil Broadway Laboratory.

(o)API Technical Data Book - Petroleum Refining. Volume I, Chapter I. Revised Chapter 1 to First, Second, Third and Fourth Editions, 1988.

(p)-Automotive Gasolines," SAE Recommended Practice, J312 May 1986, 1988 SAE Handbook, Volume 3.

(a)mer

(1) Value at 80 degrees $F$ with respect to the water at 60 degrees $F$ (Mueller \& Associates).

(a) National Institute for Petroleum and Energy Research, Petroleum Product Surveys, Motor Gasolines, Summer 1992, NIPER-178 PPS 93/1 (Bartlesville, OK, January 1993), Table 1.

MP. Dom, A.M. Mourao, and S. Herbstman, The Properties and Pertormance of Modern Automotive Fuels," Society of Automotive Engineers (SAE), Publication No. 861178 Warrendale, PA, 1986), p. 53

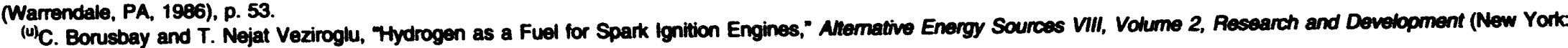
Hemisphere Publishing Corporation, 1989), pp. 559-560.

(v) Technical Date Book. Prepared by Gulf Research and Development Company, Pittsburgh, PA, 1962. 
bustion. Because the two main types of internal combustion engines-spark ignition and compression ignition engines-work differently, they require fuels with different sharacteristics (see Chapter 8).

\section{Composition}

All of the fuels except hydrogen and electricity are individual hydrocarbons, blends of hydrocarbons, or alcohols. The chemical composition of a fuel affects both its emissions and its performance. Appendix E describes the basic chemical structure of the major constituents of alternative fuels.

\section{Hydrogon}

The simplest and lightest fuel is hydrogen gas $\left(\mathrm{H}_{2}\right)$. Hydrogen is in a gaseous state at atmospheric pressure and ambient temperatures. Fuel hydrogen is not pure hydrogen gas. It has small amounts of oxygen and other materials. California, for example, has provided guidelines for the content of hydrogen fuel. In its proposed specifications, oxygen content is limited to less than 2 mole percent, which California indicates will not present an explosion concern, nor will it pose any known emissions problem. California has also proposed a particulate limit to avoid engine damage and plug ging of the fuel delivery system. ${ }^{123}$

\section{Natural Gas}

The main constituent of natural gas is methane, which is a relatively unreactive hydrocarbon. Natural gas as delivered through the pipeline system also contains hydrocarbons such as ethane and propane; and other gases such as nitrogen, helium, carbon dioxide, hydrogen sulfide, and water vapor. Typically, natural gas contains over 90 percent methane by volume (Table 23). Ethane is the next primary constituent at 3.6 percent of the volume. Nitrogen comprises 1.8 percent of the volume, followed by carbon dioxide at 1.0 percent and propane at 0.8 percent. The absence of highly photochemically reactive hydrocarbons such as olefins or aromatics indicates that natural gas has less ozoneforming potential than gasoline.

The composition of pipeline natural gas varies, depending on the source and processing of the gas as well as the time of year. In addition to variations in interstate
Table 23. Typical Volumotric and Mase Base Composition of Natural Gas

\begin{tabular}{lc|c|c}
\hline \multicolumn{2}{c|}{ Component } & $\begin{array}{c}\text { Volume } \\
\text { Percent }\end{array}$ & $\begin{array}{c}\text { Welght } \\
\text { Percent }\end{array}$ \\
\hline Methane & $\mathrm{CH}_{4}$ & 92.29 & 84.37 \\
Ethane & $\mathrm{C}_{2} \mathrm{H}_{6}$ & 3.60 & 6.23 \\
Propane & $\mathrm{C}_{3} \mathrm{H}_{8}$ & 0.80 & 2.06 \\
Butanes & $\mathrm{C}_{4} \mathrm{H}_{10}$ & 0.29 & 0.99 \\
Pentanes & $\mathrm{C}_{6} \mathrm{H}_{12}$ & 0.13 & 0.53 \\
Hexanes & $\mathrm{C}_{6} \mathrm{H}_{14}$ & 0.08 & 0.39 \\
Carbon Dioxide & $\mathrm{CO}_{2}$ & 1.00 & 2.52 \\
Nitrogen & $\mathrm{N}_{2}$ & 1.80 & 2.89 \\
Water & $\mathrm{H}_{2} \mathrm{O}$ & 0.01 & 0.01 \\
\multicolumn{1}{l}{ Total } & & 100.00 & 100.00 \\
\hline
\end{tabular}

Source: William E. Liss and William H. Thrasher, "Natural Gas as a Stationary Engine and Vehicular Fuel," Society of Automotive Engineers (SAE), Paper No. 912364 (Warrendale, PA, 1991), p. 46.

pipeline gas, some local utilities may deliver gas that is significantly different from interstate pipeline-quality natural gas. ${ }^{124}$ In some areas, gas utilities inject propane/air mixtures into the natural gas during seasonal peak periods to reduce the need for natural gas during these times. Since the chemical and physical properties of natural gas constituents are different, the variability in the composition of natural gas can affect its performance as a transportation fuel. In a survey of 10 cities, the composition and characteristics of natural gas were shown to vary considerably (Table 24). For example, heating value varies from a low of 970 Btu per standard cubic foot (scf) to 1,208 Btu/scf.

When used as fuel in vehicles, the heavier hydrocarbons in natural gas increase reactivity and condense out of the compressed gas where the high-pressure gas leaves the regulator with temperature decreasing quickly. Condensation of these hydrocarbons can also occur in the vehicle's storage tanks. In CNG vehicles, the gas is stored at elevated pressures and may be subject to low ambient temperatures. The temperature/pressure conditions may cause certain hydrocarbons, like propane, to condense. ${ }^{125}$ If heavier hydrocarbons con-

\footnotetext{
${ }^{122}$ California Air Resources Board, Proposed Specifications for Alternative Fuels for Motor Vehicles, Staff Report (October 28, 1991 ), p. 33. ${ }^{12}$ Christopher S. Weaver "Natural Gas Vehicles-A Review of the State of the Art," Society of Automotive Engineers (SAE), Paper No. 892133 (Warrendale, PA, 1989), p. 36.

${ }^{125}$ William E. Liss and William H. Thrasher, "Natural Gas as a Stationary Engine and Vehicular Fuel," Society of Automotive Engineers (SAE), Paper No. 912364 (1989), pp. 47-48.
} 
Table 24. Wolghted National Statistice for Natural Gas In Ton Major Urban Areas of the Unitod States Whth and Without Propand/Air (P/A) Peakshaving

\begin{tabular}{|c|c|c|c|c|c|c|c|}
\hline Component & Mean & $\begin{array}{l}\text { Minimum } \\
\text { With PIA }\end{array}$ & $\begin{array}{l}\text { Minimum } \\
\text { W/O PIA }\end{array}$ & $\begin{array}{l}\text { Maximum } \\
\text { Whth PIA }\end{array}$ & $\begin{array}{c}\text { Maximum } \\
\text { WIO PIA }\end{array}$ & $\begin{array}{c}10^{\mathrm{mm}} \\
\text { Porcontile }\end{array}$ & $\begin{array}{c}90^{\text {m }} \\
\text { Porcentile }\end{array}$ \\
\hline Methane (Mole \%)' . . . . . & 93.2 & 55.8 & 74.0 & 98.1 & 98.1 & 88.5 & 96.4 \\
\hline Ethane (Mole \%) . . . . . . . & 3.6 & 0.7 & 0.7 & 14.7 & 14.7 & 1.8 & 5.0 \\
\hline Propane (Mole \%) . . . . . . . & 0.8 & 0.0 & 0.0 & 23.7 & 2.4 & 0.3 & 1.3 \\
\hline C4+ (Mole \%) & 0.5 & 0.0 & 0.0 & 2.1 & 2.1 & 0.1 & 0.6 \\
\hline $\mathrm{CO}_{2}+\mathrm{N}_{2}($ Mole \%) & 2.7 & 0.1 & 0.1 & 15.1 & 10.0 & 1.0 & 4.7 \\
\hline Heating Value (Btw/sct) & 1,037 & 970 & 970 & 1,208 & 1,130 & 1,023 & 1,050 \\
\hline Specific Gravity . . . . . . . . & 0.603 & 0.566 & 0.566 & 0.883 & 0.695 & 0.578 & 0.628 \\
\hline Wobbe Number ${ }^{2}$ & 1,338 & 1,198 & 1,198 & 1,402 & 1,402 & 1,312 & 1,357 \\
\hline Air/Fuel Ratio (Mass) & 16.3 & 12.7 & 13.6 & 17.1 & 17.1 & 15.7 & 16.8 \\
\hline
\end{tabular}

'The mole fraction of a component of ideal gases equals the volume fraction of that component. Mole percent is the number of molecules of a gas component as a percent of the total number of molecules in a given volume of the gas. Moles are frequently stated in terms of grams or pounds.

${ }^{2}$ Wobbe number is the high heating value on a volumetric basis divided by the square root of the specific gravity relative to air. It represents a measure of energy flow through an orifice.

Note: "Propane/Air peak sharing" (P/A) refers to the addition of propane/air mixtures to natural gas during peak demand periods in order to reduce the need for natural gas.

Source: William E. Liss and William H. Thrasher, "Natural Gas as a Stationary Engine and Vehicular Fuel," Society of Automotive Engineers (SAE), Paper No. 912364 (Warrendale, PA, 1991), p. 46.

dense, the heating value and specific gravity of the gas will change. The condensation and revaporization lead to fuel enrichment variations. Changes in fuel enrichment affect both emissions and engine performance.

Water content is of concern because of its tendency to (1) promote corrosion of transmission pipes, vehicle storage tanks, and refueling stations; and (2) form solid hydrates. When compressed gas is allowed to expand at the regulator within the vehicle, ice crystals may form and block fuel flow if water vapor is present and if the gas is cooled below water's relative freezing point. Some regions of the country are considering further dehydration of natural gas at vehicle refueling stations to prevent formation of solid or liquid phases (hydrates or water condensates). ${ }^{126}$

Natural gas is lighter than air, which is good from a safety perspective. If natural gas escapes, it will not lie along the ground or enter sewage systems.

\section{Liquefled Petroloum Cas}

LPG, like natural gas and unlike gasoline, is a simple mixture of hydrocarbons, mainly propane/propylene $\left(\mathrm{C}_{3} \mathrm{~s}\right)$ and butane/butylene $\left(\mathrm{C}_{4} \mathrm{~s}\right)$. The chemical structures of these paraffins and olefins are discussed in Appendix E. Because the current U.S. standards restrict automotive LPG to being mostly propane, LPG automotive fuel is frequently referred to as propane. In Europe, however, automotive mixtures can contain much more butane. ${ }^{127}$ Because the mix of propane and butane in the United States may vary in the future, this document will continue to use the term LPG for automotive fuel, with physical and performance characteristics being those mainly of propane.

The limited amount of highly reactive hydrocarbons and the low sulfur content of LPG relative to gasoline or diesel indicate some of LPG's good environmental features. One of the few highly reactive hydrocarbons

\footnotetext{
${ }^{126}$ William E. Liss and William H. Thrasher, "Natural gas as a Stationary Engine and Vehicular Fuel," p. 46.

${ }^{127}$ R.F. Webb, An Assessment of Propane as an Alternative Transportation Fuel in the United States, Main report prepared for Petrolane Gas Service (Los Angeles, CA, June 1989), p. 3-3.
} 
in LPG is the olefin propylene (also called propene). Propylene not only increases emissions, it also lowers the knock-limited compression ratio, diminishing engine performance. ${ }^{128}$ The amount allowed in LPG is limited to 5 percent by the American Society for Testing and Materials (ASTM) D 1835-89 standard for fuels. Propane and butane, while gases under normal temperatures and pressures, are both heavier than air; therefore, if leakage occurs they can lie along the ground or enter sewage systems.

\section{Alcohols: Mothanol and Ethanol}

As engine fuels, ethanol and methanol have similar chemical and physical characteristics. The chemical structures of these alcohols are discussed in Appendix $E$, along with the structures of methane and ethane. As indicated in Appendix E, methanol is methane with one hydrogen molecule replaced by a hydroxyl radical $(\mathrm{OH})$, and similarly, ethanol is ethane with a hydrogen molecule replaced by a hydroxyl radical.

The addition of the $\mathrm{OH}$ radical adds polar characteristics to these molecules. Polarity in a molecule is a highly cohesive molecular bonding force. Alcohols with small hydrocarbon structures like methanol and ethanol have strong polarity, while alcohols with larger hydrocarbon structures have weak polarity. MTBE and ETBE, which are made from methanol and ethanol, respectively, are ethers. Ethers do not have the $\mathrm{OH}$ radical, and have little or no significant polarity.

At room temperature, low-molecular-weight substances like methanol would be gases if polarity did not keep them collapsed into liquids. When methanol or ethanol is dissolved in a nonpolar solvent like gasoline, the alcohol molecules become separated, and the molecular cohesion is weakened. The alcohol behaves more like a gas in such a mixture and results in a larger than anticipated increase in vapor pressure for the gasoline mixture than would be expected based on the alcohol's and gasoline's pure liquid vapor p1 essures. However, when alcohol concentrations in gasoline are at the 85-percent level, the Reid Vapor Pressure of the mixture is lower than that of gasoline alone. In addition, if water exists as a second phase with the gasoline, the polar alcohols will be drawn to the water, which is also highly polar. This becomes an issue in transporting and storing fuels because water frequently exists in tank bottoms and pipelines. The polar effects are stronger for methanol than for ethanol, and are insignificant for highermolecular-weight, lower-polar-strength alcohols. ${ }^{16}$

Methanol is highly toxic, and raises safety concerns about human ingestion, eye or skin contact, and inhalation. Precautions are needed when handling methanol.

Ethanol for fuel use must be denatured by Federal mandate. Denaturants used in industry vary in types and amounts. Different denaturants will affect driveability and durability of the vehicle. California is specifying that unleaded gasoline be the denaturant used in fuel ethanol both for E-85 and E-95 (which California calls E-100). ${ }^{130}$

\section{Electricity}

For electric vehicles, the battery is central to the vehicle's fuel system and its success. Lead acid batteries are the types currently being used in electric vehicles, but there is no consensus over what type of battery may be best for the future. A variety of battery types are being developed, including nickel cadmium, nickel iron, nickel zinc, zinc bromine, sodium sulfur, sodium nickel chloride, lithium, nickel metal hydride, zinc air, and aluminum air. ${ }^{131}$

\section{Fuel Propertles}

Although a large number of fuel properties influence engine performance, a subset of these properties are reviewed in this section to highlight differences among the petroleum-based and alternative fuels.

\section{Energy Density}

Differences in energy mass density (Btu/lb) and energy volume density (Btu/gal as a liquid or Btu/scf as a gas) do not greatly affect engine performance, but energy density differences do affect the volume and weight of fuel contained in onboard storage tanks and, thus, they impact driving range. The designation of a fuel as a liquid fuel frequently refers to its condition in the vehicle storage tank. For example, LNG, LPG, the gasolines, and the alcohol fuels are all liquid fuels in the storage tank, but they are all combusted as vapors ${ }^{132}$ in spark engine cylinders. The difference between the

\footnotetext{
${ }^{128}$ California Air Resources Board, Prospect Specifications for Alternative Fuels for Motor Vehicles, Staff Report (October 28, 1991$)$, p. 31.

${ }^{129}$ American Petroleum Institute, Alcohols and Ethers, Publication No. 4261, 2nd ed. (Washington, DC, July 1988), p. 3.

${ }^{130}$ California Air Resources Board, Prospect Specifications for Alternative Fuels for Motor Vehicles, Staff Report (October 28, 1991$)$, p. 18.

${ }^{131}$ A.P. Green, C. McGrath, and J. Murray, "Global Opportunities and Risks for Electric and Hybrid Low Emission Vehicles," Society for Automotive Engineers (SAE), Paper No. 931011 (Warrendale, PA, 1993), p. 102.

${ }^{132}$ Although the fuels may not be fully vaporized as they enter the engine, they are mostly vapor, and at the time of combustion, can be considered vaporized fuels.
} 
liquefied gases LNG and LPG and the other liquid fuels is that the liquefied gases are stored under pressure and temperature conditions that keep them in liquid form.

Conventional gasoline, oxygenated and reformulated gasoline, and diesel-which are liquids - have the highest energy densities. Ethanol and methanol also are liquids at atmospheric pressure and ambient temperatures, so they are stored and handled similarly to gasoline. Their energy densities, though, are less. Methanol has about half the energy content of gasoline on a volume basis, while ethanol has about two-thirds of the energy density. The lower energy density implies that at equivalent engine efficiency (miles per Btu), a pure-alcohol-fueled vehicle would travel half to twothirds as far as a gasoline-fueled vehicle using the same size tank. These energy density differences are compensated for somewhat by improvements in efficiency that can be realized in spark ignition engines using alcohols compared with gasoline (see Chapter 8). E-85 and M-85 have slightly higher energy densities than neat ethanol and methanol because of the addition of gasoline.

LPG, while a gas at normal temperatures and pressures, is stored in a liquid form under slight pressure (100-300 psi). While butane has a higher energy density per gallon than propane, both propane and butane have lower energy content per gallon than diesel or gasoline. The liquefied propane in the storage tank has an energy density that is about 73 percent of the energy density of gasoline by volume.

Natural gas is stored in the vehicle fuel tanks under pressure as a compressed gas. Even under fairly high pressure, both the mass density and energy density of a gas are considerably less than for a liquid.

The difference in energy densities has a pronounced effect on vehicle storage equipment. At 3,000 psi, a typical pressure for CNG vehicle fuel tanks, the volumetric energy of natural gas is about one-fifth that of diesel fuel and one-fourth of gasoline. Thus, if all other efficiencies were equal, a CNG vehicle tank would be four times the size of a gasoline tank to cover the same driving range. ${ }^{133}$ For comparison, the weight of the fuel and tank in pounds per gallon of diesel fuel equivalents are 47 pounds for natural gas in a steel cylinder, 36 pounds for natural gas in a fiber-reinforced steel tank,
26 pounds for natural gas in an advanced ffberwrapped aluminum cylinder, 18.4 pounds for methanol in a conventional tank, and 9.2 pounds for diesel in a conventional tank. ${ }^{134}$

The energy density disadvantage of CNG is partially resolved with LNG, because LNG is simply natural gas that has been liquefied. LNG tanks might be pressurized around $30 \mathrm{psi}$ and hold the liquid at a temperature of around -260 degrees Fahrenheit. Somewhere between two to four times more LNG than CNG can be stored onboard. Also, in the process of liquefying natural gas, some of the substances of concern regarding engine performance are removed, such as water and carbon dioxide. In addition, LNG vehicle tanks can be filled more rapidly than CNG tanks. ${ }^{135}$

Hydrogen is less dense than natural gas. For example, natural gas at 2,400 psi contains about 188,000 Btu per cubic foot, whereas hydrogen at the same pressure contains only 45,000 Btu per cubic foot-about one-fourth the energy per unit volume of natural gas. When the storage container is taken into consideration, natural gas would provide 140,000 Btu per cubic foot, hydrogen 33,000 Btu, and gasoline 839,000 Btu (Table 25). ${ }^{136}$

Table 25. Energy Storage Denelty (Thousand Btu per Cubic Foot)

\begin{tabular}{|c|c|c|}
\hline Fusl & $\begin{array}{l}\text { Funl } \\
\text { Only }\end{array}$ & $\begin{array}{l}\text { Fual and } \\
\text { Container }\end{array}$ \\
\hline Gasoline ............. & 900 & 839 \\
\hline Hydrogen $(2,400$ psi) . . . . & 45 & 33 \\
\hline Natural Gas (2,400 psi) . . & 188 & 140 \\
\hline Electricity $\ldots \ldots \ldots \ldots$ & 2 & 2 \\
\hline Liquid Hydrogen & 270 & $67-140$ \\
\hline LNG & 630 & 346 \\
\hline Hydride (Hydrogen) . . . . . & 309-384 & $11-143$ \\
\hline
\end{tabular}

Source: Clean Fuels Report, Vol. 4, No. 3 (June 1992), p. 105.

Despite the large variation in vehicle storage requirements that result from energy density differences, the impact of energy density on engine performance is less dramatic. When fuels are combusted in spark-ignition engines, they are primarily in a vapor or gaseous phase,

\footnotetext{
${ }^{133}$ Christopher S. Weaver, "Natural Gas Vehicles-A Review of the State of the Art," Society of Automotive Engineers (SAE) paper, No. 892133 (Warrendale, PA, 1989), p. 37.

134 Christopher S. Weaver, "Natural Gas Vehicles-A Review of the State of the Art," p. 37-38.

${ }^{130}$ Robert M. Nimocks, "Why Liquify," NGV Resource Guide, Volume 1, ed. Ellen Pollock (Denver, CO: RP Publishing Inc., June 1993), p. 117.

${ }^{136}$ The Clean Fuels Report, Vol. 4, No, 3 (Niwot, CO: J.E. Sinor Consultants, Inc., June 1992), p. 105.
} 
and gas energy densities are related to molecular weight and the relative hydrogen/carbon/oxygen content of the molecules. While methane and the highermolecular-weight compounds in gasoline differ considerably in energy volume density, in all cases the gas that enters the cylinder is a mixture of fuel and air. Air is a far larger component of the gas entering the chamber than the fuel. The volume of air coming in is regulated to provide the amount of oxygen needed to combust all the fuel (a stoichiometric mixture). Since air is $\mathbf{8 0}$ percent nitrogen, a large amount of air is added to the fuel to provide the necessary oxygen requirements.

In its gaseous state, the energy composition of natural gas varies across the country, but averages around methane's heat content of 1,010 Btu/scf (high heating value). By comparison, propane gas averages 2,517 Btu/ scf, and gasoline averages about $5,800 \mathrm{Btu} / \mathrm{scf}$ (as an ideal gas). However, energy density differences among stoichiometric mixtures are not as dramatic. A stoichiometric mixture of propane and air would have about 6 percent more energy content than an equal volume of a stoichiometric mixture of natural gas and air. Similarly, a stoichiometric mixture of gasoline and air would have about 10 percent more energy than an equal stoichiometric volume of natural gas and air. Thus, with the same engine displacement, the amount of natural gas air/fuel mixture that can be burned in each piston stroke is about 10 percent less than for gasoline. This results in about the same penalty in engine power output.

The alternative fuels for combustion engines lave a feature that helps to compensate for their lower energy densities. They all have an octane advantage over gasoline, which allows for higher engine compression ratios and thus improved efficiencies and power.

Electricity for an electric vehicle is commonly stored in a battery. Today's electric vehicles use lead acid batteries, which contain a specific energy of 30.6 watthours per kilogram (104 Btu/kg or $47 \mathrm{Btu} / \mathrm{lb}$ ). This is about $1 / 400$ th the energy density of gasoline $(19,000 \mathrm{Btu} / \mathrm{lb})$. As a result, a large number of storage batteries are needed to achieve acceptable performance. The number of batteries increases vehicle weight and takes additional space. While electric vehicle systems are much more efficient than combustion engines, the efficiency advantage can only offset the low energy density difference to a small degree. An electric car using a lead acid battery might require 0.42 kilowatthours ( $k W h$ ) per mile or about 1,433 Btu per mile, compared with a typical gasoline vehicle at 30 miles per gallon or 3,833 Btu per mile. ${ }^{137}$ That is, the electric system has about a 2.7:1 efficiency advantage over a spark-ignition system, which while significant, does not remove the 400:1 energy density disadvantage. The low energy density of vehicle batteries creates tradeoffs between size, weight, cost, and vehicle range. While this discussion focuses on the energy efficiency differences between electricity and gasoline use in a vehicle, the fuel-cycle efficiencies to produce gasoline and electricity are also very different. Gasoline is produced much more efficiently, on the average, than electricity.

\section{Volatility}

Volatility indicates a fuel's ability to vaporize under different temperatures and pressures. It is the property that most affects startup engine performance and is of particular interest for spark ignition engines, which are the predominant engines used in light-duty vehicles (see Chapter 7). While high volatility is desirable in cold weather, it can cause loss of power or vapor lock in warmer weather. High volatility can also lead to increased evaporative emissions. Thus, volatility is controlled both for engine performance and for emissions.

Volatility is not an issue with hydrogen, CNG, or LPG. As gases, they do not need to vaporize before burning, making cold-start enrichment or further blending for cold-start reasons unnecessary. Cold-start enrichment is a primary source of $\mathrm{CO}$ emissions in gasoline-fueled vehicles.

The alcohols are less volatile than gasoline when used in neat form or as 85-percent alcohol blends. The Reid vapor pressure for ethanol is 2.3 , for methanol 4.6 , and varies for gasoline between 8 and 15. Ethanol and methanol are insufficiently volatile for cold-engine starts in spark ignition engines, even at moderate temperatures. Because of the low volatility, the most important performance issues for the alcohol fuels are the cold-start problem and misfiring during warmup. ${ }^{138}$

When neat alcohols are used, various solutions to the cold-start problem have been identified-including

\footnotetext{
${ }^{137}$ U.S. Department of Energy, Office of Policy, Planning and Analysis, Assessment of Costs and Benefits of Flexible and Alternative Fuel Use in the U.S. Transportation Sector, Technical Report Four: Vehicle and Fuel Distribution Requirements, DOE/PE-0095P (Washington, DC, August 1990), pp. 39-42.

${ }^{130}$ American Petroleum Institute, Alcohols and Ethers, Publication No. 4261, 2nd ed. (Washington, DC, July 1988 ) p. 54.
} 
carrying an on-board supply of a volatile fuel for startups, such as gasohol or propane. ${ }^{139}$ The addition of gasoline to alcohol fuels (M-85 or E-85) helps to reduce the cold-start problem. Current engine technology for dedicated methanol fuel use is designed for $\mathrm{M}-85 .^{100}$ One original equipment manufacturer has demonstrated engine cold-start capability with M-85 down to temperatures as low as -20 degrees Fahrenheit using computer-controlled starting systems. ${ }^{141}$

\section{Octane}

Octane numbers measure a fuel's tendency to knock in a spark-ignition engine. Knocking occurs when the gasoline-air vapor mixture prematurely self-ignites as the mixture is compressed during the upward movement of the piston. The self-ignition occurs before the cylinder reaches the top of its stroke, causing the cylinder to push against the crank shaft instead of with it. This creates a knock, which not only works against the motive power of the engine, but also puts a strain on the mechanical parts. Generally, the higher the octane number, the higher the compression ratio that can be tolerated without knocking. Engines with higher compression ratios have more power and higher efficiencies.

The octane number is determined several ways. Using a single-cylinder standardized engine, and operating the engine under two different sets of conditions, a Research Octane Number (RON) and a Motor Octane Number (MON) are obtained. Research octane is generally higher in value than motor octane. Neither reflects well the actual performance of a multiplecylinder automobile engine. The road octane number, which is the simple average of research and motor octane $(R+M) / 2$, is the value posted on the pumps to represent some measure of antiknock characteristics. An octane number of 100 is assigned to a very high antiknock hydrocarbon, isooctane. The octane number does not cover the full range of factors influencing knock in engines, particularly for gaseous fuels like CNG and hydrogen. Over the years, other methods have been developed to quantify the knock resistance of gaseous fuels. In stationary engine applications, for example, a Methane Number approzch is used. The octane number, however, still provides a meaningful way of rating different fuels. ${ }^{142}$

While all of the alternative fuels being discussed have better octane ratings than gasoline, natural gas and hydrogen exhibit the strongest antiknock characteristics. Pure methane has a road octane number, $(R+M) / 2$, of over $120 .^{143}$ Gasoline's road octane number varies from about 86 to 94 . High quantities of other constituents in natural gas, such as propane, increase the tendency of this fuel to knock, while the inert elements such as carbon dioxide and nitrogen decrease the tendency. Generally, the amount of propane and inert elements in pipeline quality gas are such as to cancel their opposing impacts on tendency to knock. Thus, pipeline-quality gas exhibits antiknock characteristics similar to methane. ${ }^{14}$ Natural gas can be used in engines with compression ratios as high as 15:1 (versus 8-10:1 for 91 octane gasoline). ${ }^{145}$ An optimum compression ratio of $15.5: 1$ might result in $15-$ and 22 percent increases in power and engine efficiency, respectively, over a base compression ratio of 8.4:1which is more typical of gasoline-fueled engines. ${ }^{146}$

Hydrogen has a road octane number greater than that for natural gas. However, increases in compression ratios in hydrogen-fueled engines can be limited because of a tendency to ignite prematurely, prior to spark ignition. If premature ignition problems were addressed, higher compression ratios could be achieved. ${ }^{147}$

While not as good as natural gas or hydrogen, LPG has excellent antiknock characteristics. It has a road octane number of 104, allowing dedicated propane vehicles to take advantage of engines with slightly higher compression ratios than can be used with gasoline. ${ }^{148}$

\footnotetext{
${ }^{139}$ American Petroleum Institute, Alcohols and Ethers, p. 54.

${ }^{100}$ Frank Black, "An Overview of the Technical Implications of Methanol and Ethanol as Highway Motor Vehicle Fuels," Society of Automotive Engineers (SAE), Paper No. 912413 (Warrendale, PA, October 1991), p. 11.

${ }^{111}$ American Petroleum Institute, Alcohols and Ethers, p. 56.

${ }^{142}$ William E. Liss and William H. Thrasher, "Natural Gas Vehicles-A Review of the State of the Art," p. 50.

${ }^{103}$ U.S. Environmental Protection Agency, Office of Mobile Sources, Analysis of the Economic and Environmental Effects of Compressed Natural Gas as a Vehicle Fuel, Volume I, Passenger Cars and Light Trucks (Ann Arbor, Ml, April 1990), p. 48.

${ }^{14}$ Christopher S. Weaver, "Natural Gas Vehicles-A Review of the State of the Art," p. 36.

${ }^{165}$ Christopher S. Weaver, "Natural Gas Vehicles-A Review of the State of the Art," p. 36.

${ }^{146}$ U.S. Environmental Protection Agency, Office of Mobile Sources, Analysis of the Economic and Environmental Effects of Compressed Natural Gas as a Vehicle Fuel, Volume I, Passenger Cars and Light Trucks, p. 48.

${ }^{107} \mathrm{C}$. Borusbay and T. Nejat Veziroglu, "Hydrogen as a Fuel for Spark Ignition Engines," Alternative Energy Sources VIII, Volume 2, Research and Development (New York, NY: Hemisphere Publishing Corporation, 1989), p. 566.

145hould the standards for automotive LPG be changed to allow for more butane, this advantage will diminish.
} 
Both neat ethanol and neat methanol have road octane numbers of 100 , which is close to LPG's octane number. Compression ratios for alcohol fuels might be raised to $13: 1 .^{149}$

\section{Cetane}

The combustio: and ignition characteristics of diesel engine fuels are expressed in the cetane number. Fuels with high cetane numbers have low autolgnition temperatures and short ignition delay times. Cetane number is determined in a single-cylinder laboratory engine in terms of a reference fuel consisting of blends of cetane (n-hexadecane, representing 100 on the cetane scale) and HMN (2,2,4,4,6,8,8-heptamethylnonane, representing 15 on the cetane scale).

Since a high octane number means a low cetane number (see Chapter 7 ), none of the alternative fuels have cetane values high enough to be used alone in unmodified compression ignition engines. However, engine designers are developing modified compression-ignition engines for heavy-duty use that include an ignition device and other changes to accommodate the lack of cetane value in these fuels.

\section{Heat of Vaporization}

Heat of vaporization affects engine power and efficiency. It is the amount of heat absorbed by : fuel as it evaporates from a liquid state, which occurs when the fuel is mixed with air prior to combustion. Higher heat of vaporization leads to improved cooling ability. Higher cooling during the intake stroke of a spark-ignition engine results in a denser air/fuel mixture. A denser mixture has two effects: (1) it allows for greater power, and (2) it permits a greater compression ratio, which improves power and efficiency. However, although a high heat of vaporization improves power and efficiency, it also adds to cold-start problems when there is little heat in the air or in the engine to vaporize the fuel prior to spark ignition.

The alcohol fuels have much higher heats of vaporization than gasoline or diesel. For methanol, typical power increases of 10 percent from increased air/fuel mixture density have been observed in unmodified automotive engines using methanol instead of gasoline. ${ }^{150}$

\section{Flame Speed}

The speed at which a flame front propagates through a fuel/air mixture can affect engine performance and emissions. High flame speeds allow for more complete combustion and potentially leaner fuel mixtures. While the liquid fuels have similar flame speeds, methanol is thought to have a higher flame speed than gasoline. Natural gas, however, has a slower flame speed than the other fuels, which impairs spark-engine efficiency unless the spark timing is advanced to compensate. The need for advanced timing can be offset by use of high compression ratios and compact, turbulent compression chambers that decrease the distance the flame must travel. ${ }^{151}$ Hydrogen has the highest flame speed of the alternative fuels, which reduces burning time and thus heat losses from the cylinder, improving thermal efficiency over fuels with lower flame speeds. ${ }^{152}$

\section{Flame Temperature and Luminosity}

The alcohol fuels distinguish themselves in this area. For alcohol fuels, the flame temperature is lower than that of gasoline, and luminosity is so low that less thermal energy is lost through conduction or radiation. Low flame temperature also helps reduce nitrogen oxide formation. ${ }^{153}$ Low luminosity, however, is a safety issue, because the flame is essentially invisible. When gasoline is added to the neat alcohol fuels as in M-85 or E-85, it increases the luminosity. Hydrogen also is virtually invisible when burning.

\section{Autoignition Temperature}

Autoignition temperature is a measure of when a fuel will self-ignite. Self-ignition is a concern in environments where the fuel might escape and come into contact with hot engine parts. As a safety feature, high autoignition temperatures are desirable. Hydrogen has the highest autoignition temperature at about 1,065 degrees Fahrenheit, followed by natural gas, propane, methanol, and ethanol. Gasoline and diesel have the lowest autoignition temperatures at 495 and 600 degrees Fahrenheit, respectively. Based on this measure, all the alternative fuels have an advantage over gasoline. While both natural gas and hydrogen have high autoignition temperatures, they require very different amounts of energy to ignite mixtures of fuel and air. Since natural gas fuel/air mixtures are difficult

\footnotetext{
${ }^{149}$ First Interim Report of the Interagency Commission on Alternative Motor Fuels (Washington, DC, September 30. 1990 ), p. 2-7.

${ }^{150}$ American Petroleum Institute, Alcohols and Ethers, p. 53.

${ }^{131}$ Christopher S. Weaver, "Natural Gas-A Review of the State of the Art," p. 36.

${ }^{132} \mathrm{C}$. Borusbay and T. Nejat Veziroglu, Hydrogen as a Fuel for Spark Ignition Engines, p. 568.

${ }^{153}$ Frank Black, Alternative Liquid Fuels in Transportation, p. 5.
} 
to ignite, natural-gas-fueled engines must use highenergy spark plugs. ${ }^{154}$ Hydrogen fuel/air mixtures, on the other hand, need very little energy to ignite. For stoichiometric fuel/air ratios, hydrogen requires about one-tenth the energy to ignite that hydrocarbon fuels require. ${ }^{155}$

\section{Flashpoint}

The flashpoint is the lowest temperature at which combustible mixtures of fuel vapor and air form above the fuel. In the presence of a spark, such mixtures will ignite. A high flashpoint is desirable from a safety standpoint, but none of the alternative fuels has an advantage in this area. All fuels but diesel have flashpoints at ambient or lower than ambient temperatures; however, the alcohol fuels have higher flashpoints than gasoline.

\section{Flammability}

Flammability limits measure the range of fuel/air mixtures that will ignite. From a safety perspective, a wide range is less desirable than a narrow range. Of the hydrocarbon fuels, methanol has the widest flammability limits ( 7.3 percent to 36 percent) followed by ethanol. In partially filled or empty storage tanks, the alcohol fuels are more likely to produce a combustible mixture above the fuel than the other alternative hydrocarbon fuels. Gasoline tank vapors are too rich in fuel to ignite, and the addition of gasoline to the alcohol fuels reduces the flammability limits of $\mathrm{M}-85$ and E-85 compared to M-100 and E-95, respectively. Relative to gasoline, the safety concerns associated with the wide flammability limits of alcohols are offset by the safety advantages of alcohol fuels' relatively high lower-flammability limits, higher flashpoint temperatures, higher autoignition temperatures, and lower vapor pressures than gasoline. ${ }^{156}$ For example, the high lower-flammability limit of methanol keeps it from igniting in air at concentrations below about 6 percent, while gasoline will ignite at concentrations as low as 1.4 percent. ${ }^{157}$ Hydrogen has the widest flammability limits of all of the alternative fuels, ranging from 4.1 percent to 74 percent. When coupled with the small amount of energy needed to ignite fuel-air mixtures, the wide flammability limits present a safety concern for hydrogen relative to the other fuels.
While wide flammability limits are not good from a safety perspective, they can be a positive characteristic for engine performance. Wide limits increase the flexibility to vary engine power or speed under different conditions by adjusting the fuel/air ratio.

\section{Fuel Production}

This section discusses the main means of producing alternative fuels today. Future production methods using different feedstocks such as coal are discussed in Chapter 9. Production processes vary greatly for the alternative fuels. Methanol is created from a synthesis gas $\left(\mathrm{H}_{2}\right.$ and carbon monoxide), which is reacted in the presence of a catalyst. Ethanol production begins with a biomass feedstock, which is subjected to a process of cooking, fermentation, and distillation to create the alcohol. LPG is a byproduct of natural gas production and petroleum refining. Natural gas is extracted from a reservoir and separated from accompanying liquids, heavy hydrocarbons, and contaminants. The different processes not only affect the final cost of the fuel, but also require additional energy and create their own emissions.

\section{Hydrogen Production}

Two methods are generally used to produce hydrogen: (1) electrolysis and (2) synthesis gas production from steam reforming or partial oxidation (see "Methanol Production").

Electrolysis uses electrical energy to split water molecules into hydrogen and oxygen. The electrical energy can come from any electricity production source, including renewable fuels. ${ }^{158}$ DOE has concluded that electrolysis is unlikely to become the predominant method for large quantities of hydrogen production in the future. Non-electric, direct production paths such as biomass gasification are likely to require less primary energy and will potentially have lower capital costs. However, electrolysis may still play a significant role. ${ }^{159}$

As described under methanol production, producing synthesis gas results in hydrogen. The predominant method of producing synthesis gas is steam reforming

\footnotetext{
${ }^{154}$ Christopher S. Weaver, "Natural Gas Vehicles-A Review of the State of the Art," p. 41.

${ }^{155} \mathrm{C}$. Borusbay and T. Nejat Viziroglu, Hydrogen as a Fuel for Spark Ignition Engines, p. 566.

${ }^{156}$ California Department of Transportation, Division of Mass Transportation, Public Transportation Alternative Fuels, Final Report, prepared by Booz-Allen \& Hamilton, Inc., FTA/DMT-CA-80-PB92-120120 (Sacramento, CA, June 30, 1992), p. 5-3.

${ }^{157}$ U.S. Environmental Protection Agency, Office of Mobile Sources, Analysis of the Economic and Envirnnmental Effects of Methanol as an Automotive Fuel, Special Report (Washington, DC, September 1990).

${ }^{158}$ The Clean Fuels Report, Vol. 4, No. 3 (Niwot, CO: J.E. Sinor Consultants, Inc., June 1992), p. 108.

${ }^{159}$ The Clean Fuels Report, Vol. 4, No. 3 (Niwot, CO: J.E. Sinor Consultants, Inc., June 1992), p. 103.
} 
of natural gas, although other hydrocarbons can be used as feedstocks. For example, biomass and coal can be gasified and used in a steam reforming process to create hydrogen.

\section{Natural Gas Production}

Most natural gas consumed in the United States is domestically produced. In 1992, 11 percent was imported, primarily from Canada. U.S. dry gas production in 1992 was 17.8 trillion cubic feet. ${ }^{160}$

Gas streams produced from reservoirs contain natural gas liquids and other materials. Processing is required to separate the gas from petroleum liquids and to remove contaminants. First, the gas is separated from free liquids such as crude oil, hydrocarbon condensate, water, and entrained solids. The separated gas is further processed to meet specified requirements. For example, natural gas for transmission companies must generally meet certain pipeline quality specifications with respect to water content, hydrocarbon dewpoint, heating value, and hydrogen-sulfide content. The combination of processes in a typical gas plant is shown in Figure 3. A dehydration plant controls water content; a gas processing plant removes certain hydrocarbon components to hydrocarbon dewpoint specifications; and a gas sweetening plant removes hydrogen sulfide and other sulfur compounds (when present). ${ }^{161}$

\section{Liquefied Petroleum Gas Production}

LPG is a byproduct from two sources: natural gas processing and crude oil refining. Most of the LPG used in the United States is produced domestically. In 1992, 48 percent of the propane supplied came from natural gas processing, 45 percent from refineries, 5 percent from net imports, and 2 percent from existing stock drawdown. The majority of LPG imports are from Canada, which supplied 73 percent in $1992 .{ }^{162}$

\section{Figure 3. Gas Conditioning and Llquids Recovery}

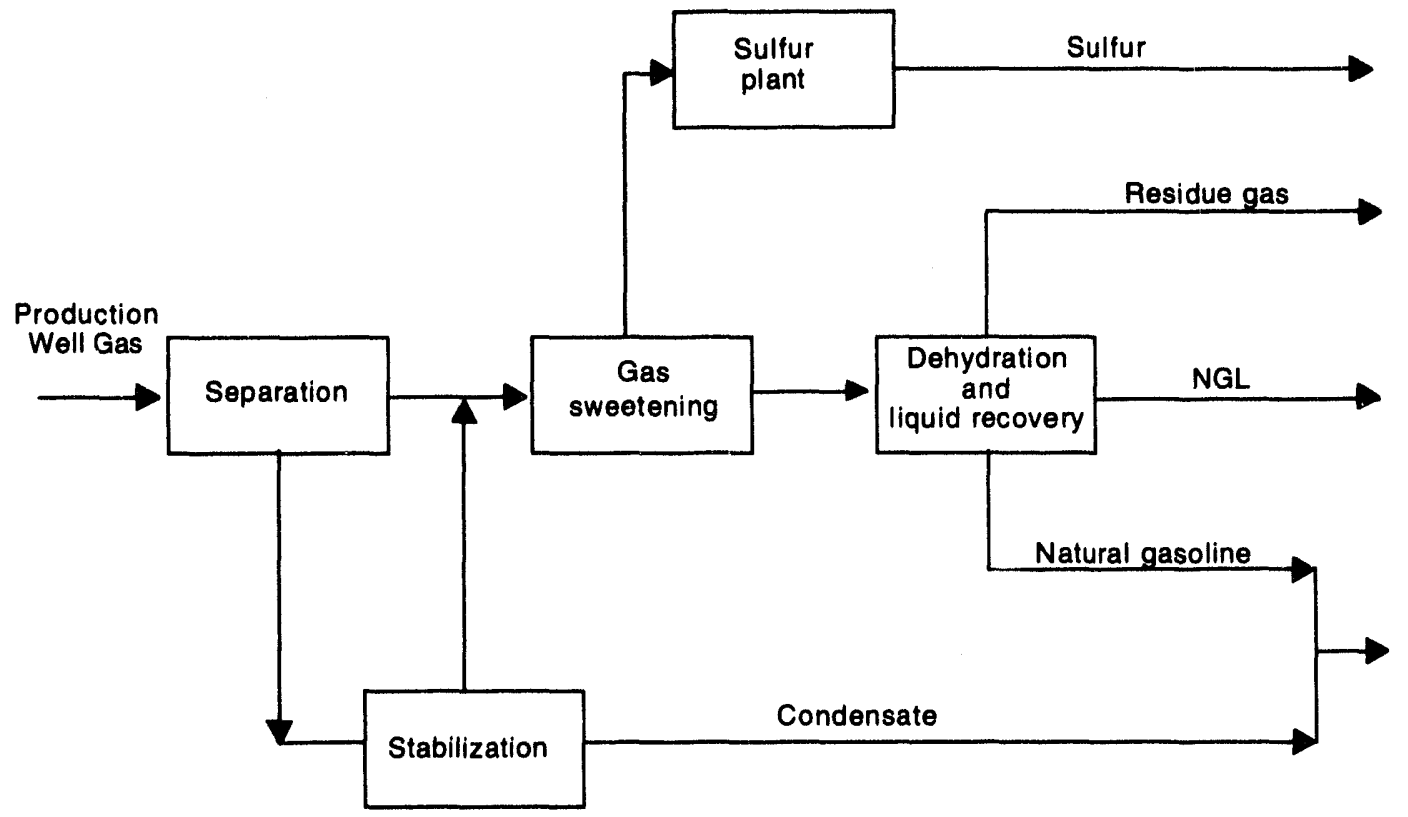

Source: Dale H. Beggs, Gas Production Operations (Tulsa, OK: OGCI Publications, 1984).

\footnotetext{
${ }^{160}$ Energy Information Administration, Natural Gas Annual 1992, Volume 1, DOE/EIA-0131(92)/1 (Washington, DC, November 1993), Table 1.

${ }^{161}$ Dale H. Beggs, Gas Production Operations (Tulsa, OK: OGCI Publications, 1984), pp. 213-222.

${ }^{162}$ Energy Information Administration, Petroleum Supply Annual 1992, Volume 1, DOE/EIA-0340(92)/1 (Washington, DC, May 1993), Tables 3 and 21.
} 
When natural gas is produced, it contains methane and other light hydrocarbons that are separated in a gas processing plant. Since propane boils at -44 degrees Fahrenheit and ethane 'the next lighter hydrocarbon) boils at -127 degrees Fahrenheit, separation from methane (which boils at -259 degrees Fahrenheit) is accomplished through a combination of increasing pressure and decreasing temperature. Low temperatures are achieved by refrigeration and expansion of a compressed gas (gas uses its own energy to expand, causing the temperature to drop).

The natural gas liquid (NGL) components recovered during processing include ethane, propane (paraffin), and butane, as well as heavier hydrocarbons. Quantities of NGL components vary considerably among different sources of natural gas streams. Nearly all of the $C_{3}$ s in NGL are propane.

Propane and butane, along with other gases, are also produced during crude refining as a byproduct of the processes that rearrange and/or break down molecular structure to obtain more desirable petroleum compounds. Reforming and catalytic cracking are the two refinery processes that are the principal sources of propane and butane. (Ethane is also produced, but it is usually used within the refinery as fuel.) In refining, the $\mathrm{C}_{3} \mathrm{~s}$ and $\mathrm{C}_{4} \mathrm{~s}$ produced in the catalytic cracking unit are a mixture of paraffins and olefins. Table 26 shows typical LPG yields in reforming and catalytic cracking processes and a breakdown of typical sources of propane produced in a refinery.

\section{Methanol Production}

Methanol is predominantly produced by steam reforming of natural gas to create a synthesis gas, which is then fed into a reactor vessel in the presence of a catalyst to produce methanol and water vapor. Although a variety of feedstocks other than natural gas can and have been used, today's economics favor natural gas. Other feedstocks include naphtha, vacuum gas oil, coal and biomass. About 71 percent of U.S. onstream capacity is designed for natural gas feedstock.

Table 26. LPG from Refineries

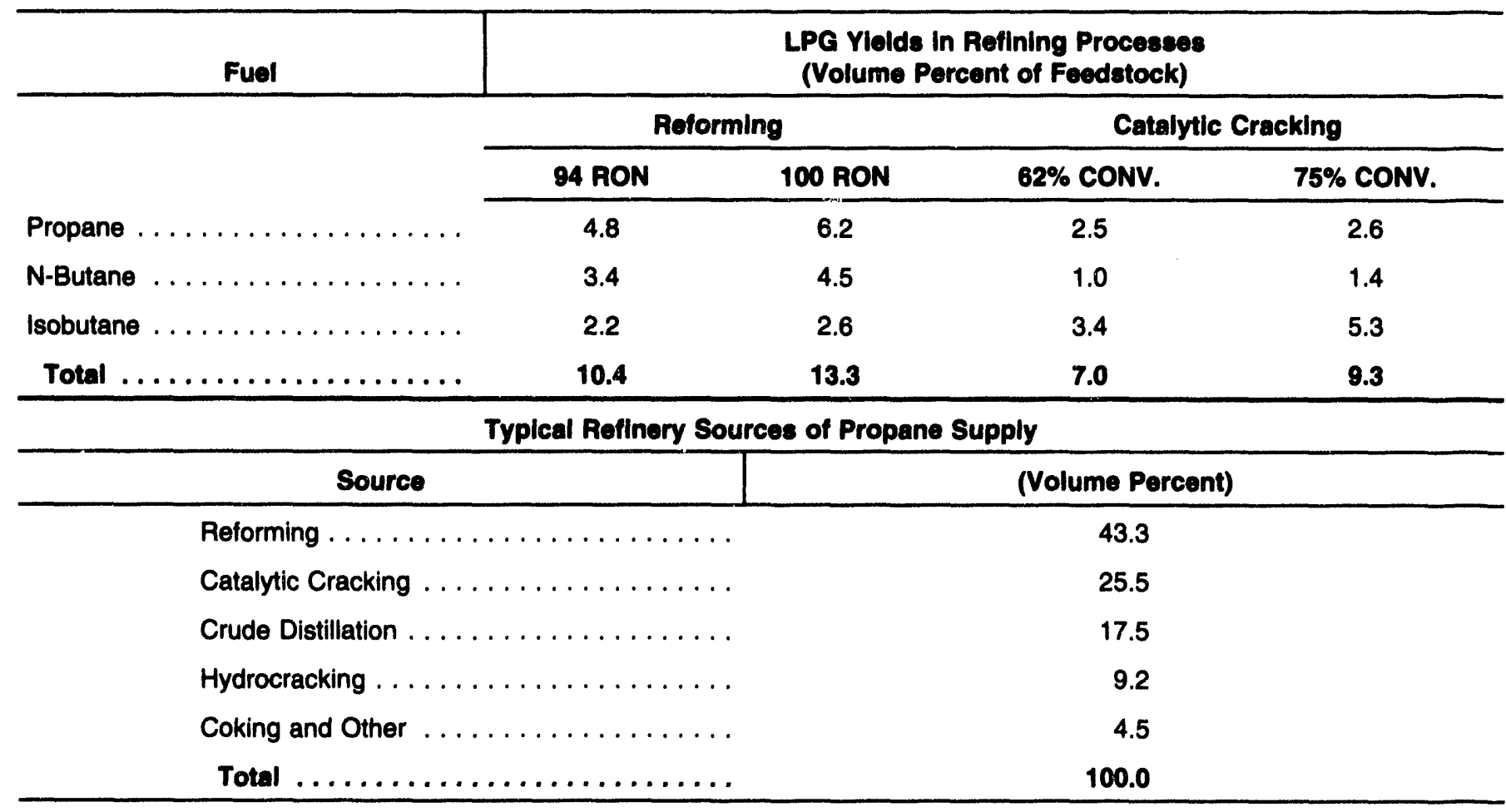

Notes: RON, Research Octane Number. CONV., Conversion. For this table, reforming feedstock is naphtha (boiling range 160$350^{\circ} \mathrm{F}$ ) and cat cracking feedstock is vacuum gas oil (boiling range $650-1,050^{\circ} \mathrm{F}$ ). In fluid catalytic cracking, conversion is a measure of the severity of operations (i.e., how much of the high molecular weight material is converted into gasoline and lighter material). It is defined as 100 percent minus the percent of unconverted material. Reforming severity is discussed further in Chapter 7.

Source: J.L. Glazer and G.G. Clark, "LP-Gas Value Upgrading-New Market Channels," Gas Processors Association Paper. Proceedings of the Sixty-Fourth Annual Convention (Tulsa, OK, 1985), p. 362. 
An additional 8 percent uses other light hydrocarbons. ${ }^{163}$ When feedstocks other than natural gas are used, further processing may be needed, such as steps to remove sulfur from the synthetic gas stream. Sulfur can poison the catalysts used in the process. This section discusses processing natural gas into methanol, and since natural gas is usually free from significant sulfur, desulfurization and other feedstock processing will not be covered.

Synthesis Gas Production. Synthesis gas refers to combinations of carbon monoxide (CO) and hydrogen. While a large amount of synthesis gas produced is used to make methanol, most synthesis gas is used to make ammonia. As a result, most methanol plants are adjacent to or are part of ammonia plants.

Synthesis gas is produced by either steam reforming or partial oxidation. The process chosen is a function of the feedstocks. In the case of natural gas (or other lighter feedstocks such as LPG or naphtha), steam reforming is generally used. The small amount of methanol produced from heavier feedstocks such as coal is produced via the partial oxidation route. ${ }^{164}$

In steam reforming, methane feedstock is passed over a nickel catalyst along with steam. The process takes place under high temperatures and pressures in a vessel similar to a cracking furnace. The reaction converts the methane and water to $\mathrm{CO}$ and hydrogen. ${ }^{165}$ A simplified representation of the reaction is:

$$
\mathrm{CH}_{4}+\mathrm{H}_{2} \mathrm{O} \rightarrow \mathrm{CO}+3 \mathrm{H}_{2} \text {. }
$$

Methanol from Synthesis Gas. The synthesis gas is fed into another reactor vessel under high temperatures and pressures, where the $\mathrm{CO}$ and hydrogen are combined in the presence of a catalyst (usually copperzinc oxide) to produce methanol. The following reaction occurs:

$$
\mathrm{CO}+2 \mathrm{H}_{2} \rightarrow \mathrm{CH}_{3} \mathrm{OH}
$$

Finally, the reactor product is distilled to purify and separate the methanol from the reactor effluent. The unreacted synthesis gas is recovered and recycled to the reactor vessel. This procedure produces methanol of 99 percent purity. Byproducts include small amounts of dimethyl ether and higher alcohols. ${ }^{166}$

\section{Ethanol Production}

Most ethanol in the United States is produced through a process of hydrolysis, saccharification, and fermentation using grain as a feedstock. Corn is the grain of choice because of its high degree of availability and price. Therefore, the majority of U.S. ethanol production is located in the corn-growing Midwest. ${ }^{167}$

For the most part, fuel ethanol production is for domestic use. However in 1988, ethanol producers began exporting to Brazil, where ethanol is the primary transportation fuel. Exports peaked in 1990 at about 100 to 150 million gallons. ${ }^{168}$ In 1992, producers again focused on the U.S. market in preparation for the first oxygenated gasoline season. Production that year reached a record 1,083 million gallons.

Ethanol production from grain is summarized in Figure 4. Current commercial technology cannot fully convert the cellulose component of feedstocks to ethanol. A major goal of research and demonstration programs is to economically convert not only the starchy component to fermentable sugars but also the cellulose component in order to increase yields. Methods of improving or combining the saccharification and fermentation processes are also targeted. Use of new methods of this type could, for instance, enable the processing of grain hulls or the use of wood as a feedstock.

\section{Electricity Production}

In the United States in 1992, 2.8 trillion kilowatthours of electricity were produced. Petroleum-fired steam plants produced only 0.1 trillion kilowatthours, or 3 percent of total production. Coal-fired steam plants

\footnotetext{
${ }^{163}$ U.S. Department of Energy, Office of Policy, Planning, and Analysis, Assessment of Costs and Benefits of Flexible and Alternative Fuel Use in the U.S. Transportation Sector, Technical Report Three: Methanol Production and Transportation Costs, DOE/PE-0093 (Washington, DC, November 1989), p. B-5.

${ }^{164}$ U.S. Department of Energy, Office of Policy, Planning, and Analysis, Assessment of Costs and Benefits of Flexible and Altermative Fuel Use in the U.S. Transportation Sector, Technical Report Three: Methanol Production and Transportation Costs,, p. 1.

${ }^{165}$ D.L. Burdick and W.L. Leffler, Petrochemicals in Nontechnical Language (Tulsa, OK: PennWell Publishing Co., 1990 ), p. 150.

${ }^{166}$ D.L. Burdick and W.L. Leffler, Petrochemicals in Nontechnical Language, pp. 153-155.

${ }^{167}$ Mindy Petrulis et al., U.S. Department of Agriculture, Economic Research Service, Ethanol Production and Employment, Agriculture Information Bulletin No. 678 (Washington, DC, July 1993), p. 1.

${ }^{168}$ Information Resources, Inc., Implementing the Clean Air Act: Fuel Reformulation and Regulations in the 1990's, Final Draft (Washington, DC, October 1, 1992), pp. ix-24, 25.
} 
Figure 4. Stops In Ethanol Production

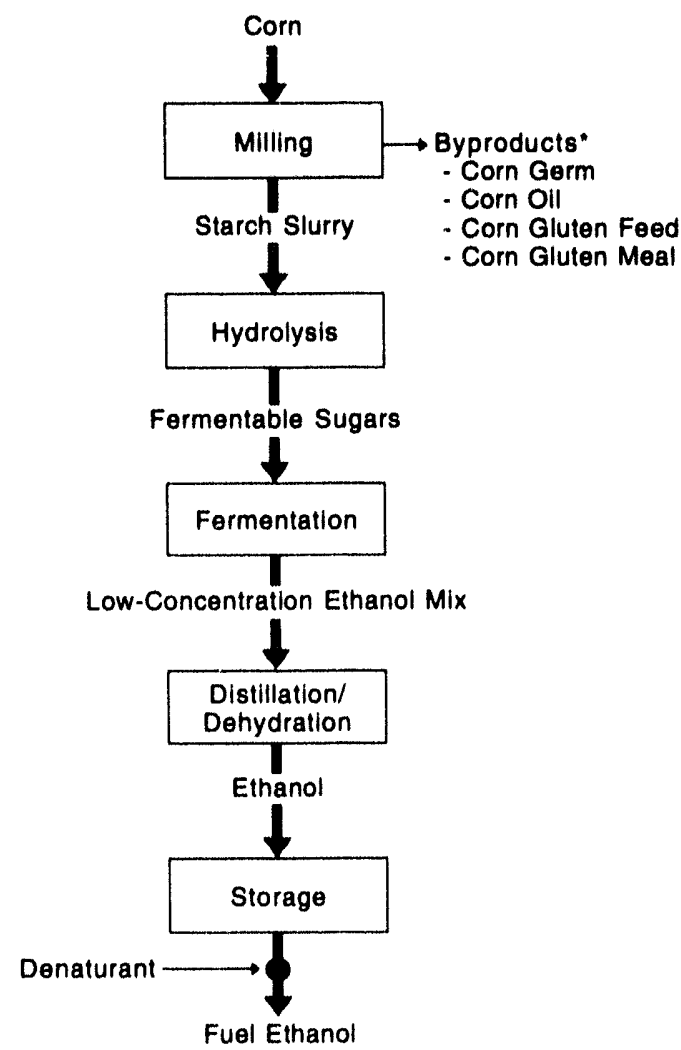

"Byproducts produced depend on the type of milling, i.e, dry milling or wet milling.

Source: Paul P. Wood, "New Ethanol Process Technology Reduces Capital and Operating Costs for Ethanol Producing Facilities," Fuel Reformulation (Denver, CO: Hart Publications, Inc., July/August 1993), pp. 56-64.

produced 56 percent of electricity supplied; nuclear plants, 22 percent; natural-gas-fired steam plants, gas turbines, and internal combustion turbines, 10 percent; and hydroelectric plants, 9 percent. Geothermal, wood, waste, wind, and solar supplied less than 0.5 percent of electric power needs. ${ }^{169}$

While the existing electricity infrastructure is available to supply power to electric vehicles, one concern is how widespread electric vehicle use will affect the load curve driving today's capacity mix requirements. Utilities use different types of units to supply continuous baseload requirements, intermediate requirements, and peak load needs. Overnight recharging of vehicles is attractive to utilities in that it requires power when other power demands are low. Daytime recharging, however, could increase peak loads. From an emissions standpoint, the type of fuel used in the power plants to supply the vehicles is also important. Coal-fired plants, for example, produce more greenhouse gases and other emissions than do nuclear and hydroelectric plants.

Electricity production from standard power plants is about 32 percent efficient (e.g., 10,600 Btu of coal to produce 3,412 Btu of electricity). If energy efficiency of power plants is improved over the years and more energy is supplied from cogeneration units that have much higher overall efficiencies due to their use of waste heat, the total fuel cycle energy efficiency of electric vehicles could improve significantly.

\section{Fuel Distribution}

Alternative fuels will be attempting to penetrate a conventional fuel market that has a well-developed infrastructure. Unfortunately, they generally cannot make use of the existing petroleum fuel infrastructure. Some fuels, such as natural gas, already have a significant infrastructure in place because of their other uses. Other fuels, such as methanol, have very little infrastructure to serve a vehicle market. Additional infrastructure needs for alternative fuels in some cases may be a hurdle to market penetration. This section briefly reviews the distribution system for each fuel.

\section{Hydrogen}

A distribution system for hydrogen as a transportation fuel does not exist. While pipeline transportation is generally the most economic means of transporting gaseous fuels, a pipeline system is currently not in place. Transportation of hydrogen is typically in canisters and tanker trucks.

\section{Natural Gas}

Natural gas is distributed throughout the United States in extensive pipeline systems that extend from the wellhead to the end user. Every continental State has access to natural gas through pipelines. The pipeline system consists of long-distance transmission systems, followed by local distribution systems. Some underground storage is also used to help supply seasonal peak needs. The distribution system is operated at lower pressures than the transmission system. ${ }^{170}$ In 1992 , the distribu-

${ }^{164}$ U.S. Department of Energy, Annual Energy Review 1992, DOE/ElA-0384(92) (Washington, DC, June 1993 ), p. 219.

${ }^{170}$ U.S. Department of Energy, Office of Policy, Planning, and Analysis, Assessments of Costs and Benefits of Flexible and Alternative Fuel Use in the U.S. Transportation Sector, Technical Report Four: Vehicle and Fuel Distribution Requirements, DOE/PE-0095P (Washington, DC, August 1990), p. 32. 
tion system was able to serve $\mathbf{5 2 . 3}$ million residential consumers, 4.4 million commercial consumers, and $\mathbf{0 . 2}$ million industrial establishments. ${ }^{171}$

The main issue with CNG distribution for transportation purposes is the lack of refueling stations. The rest of the distribution system is well developed. In 1992, the National Renewable Energy Laboratory reported 349 CNG public and private refueling sites. Refueling CNG vehicles requires connecting a manifold on the vehicle to a high-pressure gas line. ${ }^{172}$ A refueling station takes natural gas from the low pressure distribution pipeline and compresses it for transfer to the vehicle.

Slow-fill stations attach the vehicle directly to a compressor and have little or no storage capacity. Refueling time is dependent on the compressor, but might be 6 to 8 hours for automobiles. ${ }^{173}$ Slow-fill stations are used for fleet vehicles that can remain idle in a single location for a period of time. The pressure in the vehicle cylinders rises as they fill, and when they reach a specified pressure, the compressor automatically shuts down. Fast-fill stations are similar, but they have storage capacity to allow filling in a short period of time comparable to gasoline refills (5-7 minutes for automobiles). The compressor must be able to handle peak demand without falling behind. A cascade of highpressure cylinders, containing gas at different pressures, provides the storage. Refueling occurs by equalizing pressure with each cylinder in turn, in ascending sequence (Figure 5). A home compressor is also available for individual use. It is a slow-fill compressor sized to refuel one or two vehicles in a residential driveway. ${ }^{174}$

\section{Liquefied Petroleum Gas}

Natural gas liquids (which include LPG) are extracted from natural gas in the gas processing plants located near gas producing areas. This "raw mix" is then moved through pipelines to fractionation facilities, which separate the raw mix into ethane, propane, butane, and other products. Most fractionators are located at central pipeline hubs or large refining/ chemical plant centers. The largest fractionation centers are at Mont Belvieu, Texas (Gulf Coast); the ConwayHutchinson area of Kansas; Hattiesburg, Mississippi; and in the Texas Panhandle. Large underground storage areas for the raw mix and fractionated products are located in the same areas. Additional storage areas exist in the major markets of the Midwest, Northeast, and Southeast.

From the major fractionation storage areas, LPG is moved by pipeline, barges, tankers, railroad cars, and trucks to the end user. Pipelines provide the primary means of moving LPG long distances. Gathering pipelines take raw mix to the fractionators, while distribution pipelines move LPG from the fractionators to the major market areas. The LPG pipeline system is not as extensive as the natural gas pipeline system. The pipelines mainly cover the Midwest, and two major lines go into the Southeast and the Northeast. Most LPG is consumed in areas served by these pipelines. Trucks carry LPG to bulk plants. From bulk storage facilities, a network of independent or branded retail distributors receive and deliver propane to the end users, either by truck or through direct sales of cylinders.

Since LPG is stored under pressure both inside the vehicle and in the refueling tanks, special refueling equipment is needed to transfer the pressurized liquid from the storage tanks to the vehicle and to ensure that no LPG escapes during refueling. Refill time for an LPG vehicle container is similar to filling a gasoline or diesel tank. LPG requires the use of a special pressure-resistant filling connection instead of the conventional hose. $^{175}$

The weakest link in the LPG distribution system to widespread use of LPG as a transportation fuel is the lack of refueling stations. An advanced LPG distribution network exists for various retail uses, but transportation refueling facilities are not available at all retail outlets. The National Renewable Energy Laboratory reported 3,297 retail refueling stations. ${ }^{176}$ However, this number may be low, since it represents facilities

\footnotetext{
${ }^{171}$ Energy Information Administration, Natural Gas Annual 1992, Volume 1, DOE/EIA-0131(91) (Washington, DC, November 1993), Table 17.

${ }^{172}$ Christopher S. Weaver, "Natural Gas Vehicles-A Review of the State of the Art," p. 38.

${ }^{173}$ Annalloyd Thomason, "NGVs: What Every Customer Should Know," NGV Resource Guide, Volume 1, ed. Ellen Pollock (Denver, CO: RP Publishing, June 1993), p. 7.

${ }^{174}$ U.S. Department of Energy, Assessment of Costs and Benefits of Flexible and Alternative Fuel Use in the U.S. Transportation Sector, Technical Report Four: Vehicle and Fuel Distribution Requirements, DOE/PE-0095P (Washington, DC, August 1990), pp. 32-33.

${ }^{175} \mathrm{H}$. Bergmann and B. Busenthur, "Facts Concerning the Utilization of Gaseous Fuels in Heavy-Duty Vehicles," Conference Proceedings: Gaseous Fuels for Transportation I, Vancouver, BC Canada, hosted by BC Research and Institute of Gas Technology, August 1986 (Chicago, IL, April 1987), p. 842.

${ }^{176}$ U.S. Department of Energy, Office of Transportation Technologies, Transportation Energy Data Book, Edition 13, ORNL-6743 (Oak Ridge, TN, March 1993), Table 5.2.
} 


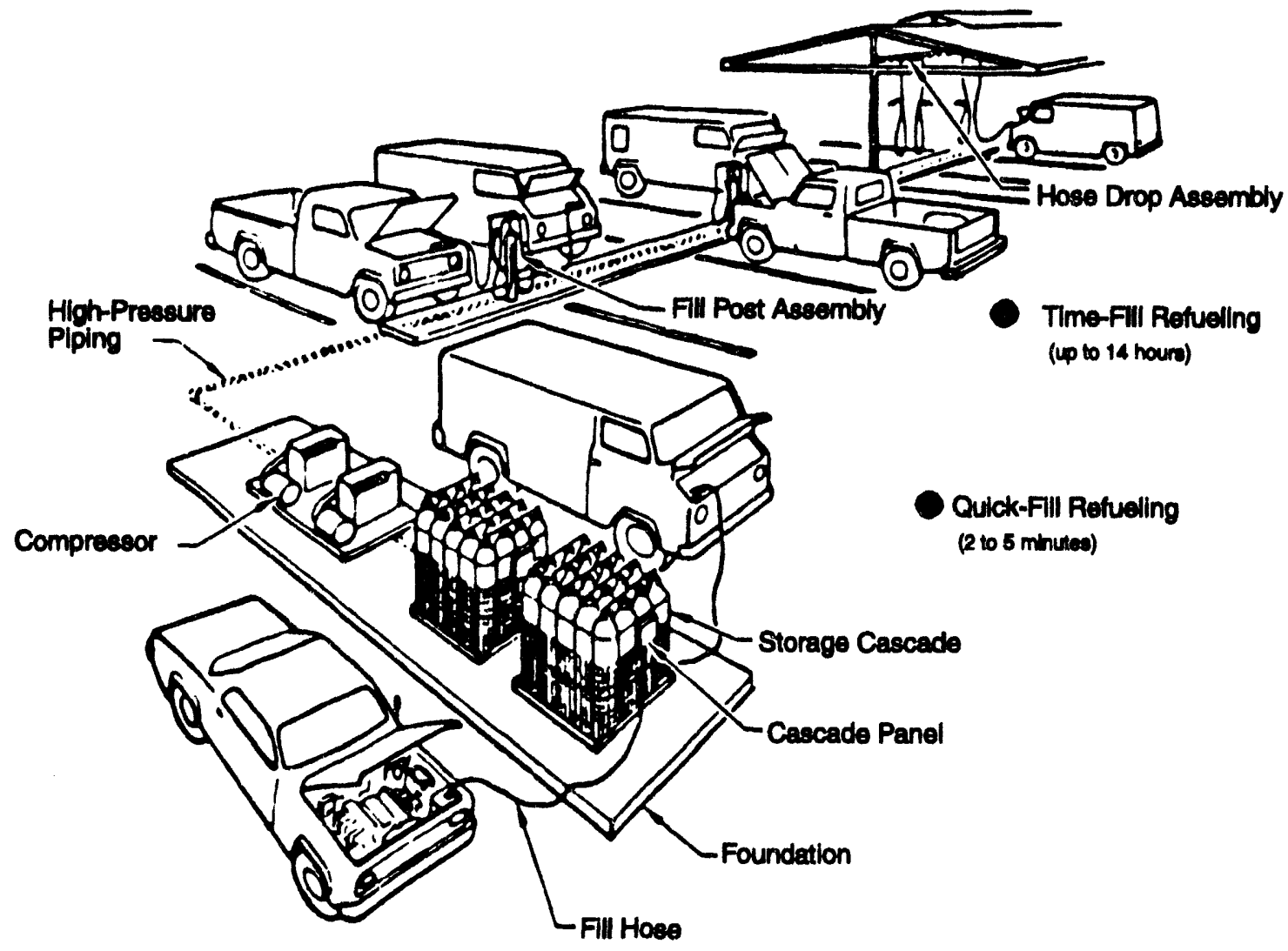

Source: U.S. Department of Energy, Office of Policy, Planning and Analysis, Assessment of Costs and Benefits of Flexible and Alternative Fuel Use in the U.S. Transportation Sector. Technical Report Four, Vehicle and Fuel Distribution Requirements, DOE/PE0095P (Washington, DC, August 1990), p. 33.

that wished to pay a small fee to be published in an LPG refueling directory. ${ }^{17}$

Because marine and pipeline transportation are inexpensive relative to other transportation modes, the areas of the country served by long-distance pipelines or marine facilities are more likely to use LPG as a transportation fuel than areas distant from production facilities, marine terminals, or pipeline access.

\section{Methanol and Ethanol}

Methanol and ethanol will probably be transferred from import terminals or production facilities by barge, rail, or truck to eventually reach retail outlets. While the alcohols are liquids at ambient temperatures and atmospheric pressures, they cannot be moved easily through the existing petroleum product network to end users, for three reasons.

First, alcohols cannot use the current petroleum pipeline system. They may suffer water contamination, phase separation in the case of M-85 or E-85, or crosscontamination from other petroleum products. Second, corrosive properties of alcohols make many of today's existing storage facilities as well as pipelines unsuitable for use with these fuels. The contamination and corrosive issues are resolvable, ${ }^{178}$ but in the near term,

17 “Never Far from the Fuel," Butane Propane News, Vol. 24, No. 3 (Arcadia, CA, March 1992), p. 30; and LPG Clean Fuels Coalition.

${ }^{178}$ First Interim Report of the Interagency Commission on Alternative Motor Fuels (Washington, DC, September 30, 1990), pp. 4-29, 30. 
the petroleum pipeline system will not be used. Third, while splash blending ${ }^{179}$ of methanol or ethanol and gasoline will be possible in the initial stages of growth, if large volumes of $\mathrm{M}-85$ or $\mathrm{E}-85$ are to be used, petroleum product terminals may have to be altered to deal with automatic blending of the two products. However, since new dedicated truck loading racks may be needed to prevent water and product cross contamination, inline blenders can be added when they are installed. ${ }^{180}$

Safety concerns for methanol and ethanol differ from those for gasoline. Therefore, these alcohol fuels will require different equipment and handling procedures. Generally, M-85 or E-85 is offered at a gasoline retail outlet that contains the appropriate storage and dispensing facilities for alcohols. At the retail outlet, materials must be compatible with alcohols' corrosive characteristics. For example, methanol underground storage tanks must be made of carbon steel or specially formulated fiberglass. A fuel filter must be added to remove rust particles that are loosened from the tank walls by the methanol. Dispenser materials must also be compatible with the alcohols. ${ }^{181}$

Because methanol is not widely used, retail outlet information is limited. California reported 31 retail outlets operating in 1992 (compared with over 13,000 gasoline outlets in the State). California probably has the majority of U.S. retail outlets selling M-85 today, and is planning soon to have a total of 82 outlets. ${ }^{182}$ The National Renewable Energy Laboratory reported 43 outlets (both public and private) across the country in $1992 .{ }^{183}$

Market penetration of M-85 and methanol is projected by DOE to develop in the vicinity of marine terminals because of the high cost of shipping the product long distances by rail or truck and the potential need for imports. Based on an analysis indicating that trucking gasoline for a 100-mile radius around marine terminals is economical, it was assumed the same would be true for methanol. Since approximately 75 percent of the vehicle miles traveled in the United States are within these 100 -mile radii, methanol should be able to reach a large market in spite of current distribution limitations. ${ }^{184}$

Ethanol is already penetrating the transportation market through gasohol. Although an exact figure is not available, there are many gasohol outlets. However, ethanol used in gasohol is not an alternative fuel as defined by EPACT. It is a replacement fuel and is discussed in this capacity in Chapter 7. Since E-85 is not being widely used, and E-95 is only undergoing demonstration, few outlets for these alternative fuels are currently available. Distribution of gasohol currently is strongest around the major ethanol production centers in the Midwest.

For LNG, the natural gas pipeline system allows liquefaction plants to be situated in any strategic location for end users. Once the gas is liquefied, it can be transferred in appropriate containers to its destination by rail, truck, or barge. After the LNG is stored at a refueling station, it can also be pumped and vaporized into CNG. LNG facilities can be designed to store more fuel than CNG stations, and they can hold perhaps several days' to a week's fuel.

\section{Electricity}

Electricity is produced from power plants located throughout the country, transmitted to substations through high voltage transmission systems, stepped down to lower voltages, and carried to homes and businesses through distribution systems. The Electric Power Research Institute (EPRI) describes the electric vehicle infrastructure as being 98 percent in place. The remaining 2 percent is developing the connection from the grid to the vehicle and determining how recharging vehicles might affect the grid. ${ }^{185}$

It takes 6 to 10 hours to recharge batteries of ordinary electric vehicles, thus recharging would generally be done at night. The length of time to recharge, when coupled with a short range, is a major disadvantage for electric vehicles over other alternative fueled vehicles. As a result, an important developing technology is fast

\footnotetext{
${ }^{179}$ Splash blending refers to loading fuel components separately into tank trucks versus automatically blending components prior to loading.

${ }^{180}$ U.S. Department of Energy, Assessments of Costs and Benefits of Flexible and Alternative Fuel Use in the U.S. Transportation Sector, Technical Report Four: Vehicle and Fuel Distribution Requirements, DOE/PE-0095P (Washington, DC, August 1990), pp. 18-21.

${ }^{81}$ U.S. Department of Energy, Assessments of Costs and Benefits of Flexible and Alternative Fuel Use in the U.S. Transportation Sector, Technical Report Four: Vehicle and Fuel Distribution Requirements, DOE/PE-0095P (Washington, DC, August 1990), pp. $20-21$.

${ }^{182}$ California Energy Commission, Transportation Technology and Fuels, chart titled, "Methanol Fueling Locations in California" as of July 15, 1992.

${ }^{183}$ U.S. Department of Energy, Office of Transportation Technologies, Transportation Energy Data Book, Edition 13, Table 5.2.

${ }^{184}$ U.S. Department of Energy, Office of Policy, Planning, and Analysis, Assessments of Costs and Benefits of Flexible and Alternative Fuel Use in the U.S. Transportation Sector, Technical Report Four: Vehicle and Fuel Distribution Requirements, pp. 18-19.

${ }^{185}$ Taylor Moore, "Charging Up for Electric Vehicles," EPRI Journal, Vol. 18, No. 4 (June 1993), pp. 8-9.
} 
charging of electric vehicles. Recharging can take place indoors or outdoors, but hydrogen is emitted by lead acid batteries as they recharge, so indoor recharging facilities must be well-ventilated.

Ideally, convenient electric charging may someday be available not only at home, but also at workplace parking areas, parking meters, and other public locations. This vision requires common standards and equipment compatibility. A semiformal group comprising EPRI, utilities, representatives of automotivestandard-setting bodies, component suppliers, and the Big Three U.S. auto manufacturers (Chrysler, Ford, and
General Motors) is meeting to work on these issues. Although complete standards are not in place, current vehicles being offered to general consumers will meet common voltage and current standards that will support 6- to 8-hour home charges-particularly during off-peak hours. ${ }^{186}$

The basic initial charging standard being pursued in the United States is a $240-\mathrm{V} / 30-\mathrm{A}$ circuit, similar to the circuits used by home electric clothes dryers. New commercial electric vehicles will likely have built-in electric converters for changing the utility alternating current into direct current for the batteries. ${ }^{187}$

\footnotetext{
${ }^{186}$ Taylor Moore, "Charging Up for Electric Vehicles," p. 10.

${ }^{187}$ Taylor Moore, "Charging Up for Electric Vehicles," p. 10.
} 


\section{Traditional and Replacement Fuels}

This chapter reviews gasoline and diesel-traditional fuels-and the replacement fuels being used with gasoline. The largest category of replacement fuels consumed in 1992 is oxygenates. The oxygenates are important components of both oxygenated and reformulated gasolines and are discussed in that context.

\section{Gasolines}

\section{Overview}

Oxygenated gasoline, reformulated gasoline, and conventional gasoline are the crude-oil-derived fuels against which alternative fuels are being compared. The oxygenates that are added to gasoline are partly or wholly derived from sources other than crude oil, and thus are replacement fuels which reduce the need for crude oil. The two major replacement fuels used as oxygenates today are MTBE and ethanol. Although these are only additives to gasoline, their volumes (roughly 2.3 percent of total gasoline consumption) in 1992 far exceeded alternative fuel use.

\section{Oxygenated Gasoline}

Oxygenated gasoline has been mandated by law to address CO emissions. Under the 1990 CAAA, EPA identified areas in the United States that did not meet CO air standards. Subsequently, EPA designated 39 areas that are required to use oxygenated gasoline during the winter months. Consumers in these areas use about 30 percent of the Nation's gasoline. ${ }^{188}$

$\mathrm{CO}$ emissions result from incomplete combustion of gasoline, and are worse during the winter months. Low temperatures and high altitudes increase $\mathrm{CO}$ emissions in vehicle exhaust, particularly during cold starts, which last until the engine warms. Increasing the oxygen content of gasoline improves combustion and reduces $\mathrm{CO}$ emissions. EPA specified that oxygenated gasoline contain no less than 2.7 percent oxygen by weight.

Oxygen content in gasoline is increased by adding oxygenates. Oxygenates are liquid organic compounds, such as alcohols or ethers, which contain oxygen and are "substantially similar" to motor gasoline as approved by the EPA. Virtually the only two oxygenates used during the first oxygenated gasoline season (winter 92/93) were MTBE and ethanol. In the CO nonattainment areas, during that part of the season when all areas were participating, about 77 percent of the oxygenated gasoline consumed used $\mathrm{MTBE}$, and 23 percent used ethanol.

\section{Reformulated Gasoline}

Reformulated gasoline (RFG) was mandated to reduce vehicle hydrocarbons and toxic emissions ${ }^{189}$ in ozone nonattainment areas. Prior to the 1990 CAAA, the term "reformulated gasoline" was sometimes used to mean any fuel that was altered as a result of EPA regulations or that was created to gain share in the "clean fuel" market. When used in this chapter, the term is as defined in the CAAA.

The basic RFG program identifies nine affected areas that have the highest ozone problems. These areas cover more than 22 percent of the U.S. population. There are other ozone nonattainment areas that can also opt-in to the program. If they do, more than half of the country will be participating. ${ }^{190}$

RFG is defined both by characteristics and in terms of its ability to achieve particular emissions goals. The goals of the reformulated gasoline program are:

- Phase I: Between 1995 and 1999, aggregate "baseline" vehicle summer volatile organic compound $(V O C)^{191}$ emissions and year-round toxic emissions

\footnotetext{
${ }^{188}$ Not all areas chose to participate during the first season, as described in the lead article in the Energy Information Administration's Petroleum Supply Monthly, DOE/EIA-0109(93/07) (Washington, DC, July 1993).

${ }^{189}$ Toxic air pollutants regulated under Section 219 of the CAAA are the aggregate emissions of benzene, 1,3-butadiene, polycyclic organic matter, acetaldehyde, and formaldehyde.

${ }^{190}$ Estimates are based on share of U.S. gasoline sales in participating areas.

${ }^{191}$ Volatile organic compounds (VOCs) are precursors of ozone and are toxic. The term is sometimes used in place of "unburned hydrocarbons" because some organic compounds being emitted may contain elements other than hydrogen or carbon.
} 
will be 15 percent lower than emissions from the same vehicles using "baseline" fuel. ${ }^{192}$

- Phase II: By 2000, "baseline" vehicle summer VOC emissions and year-round toxic emissions ${ }^{193}$ will be 20 to 25 percent lower than emissions from the same vehicles using "baseline" fuel.

- There will be no increase in $\mathrm{NO}_{\mathrm{x}}$ emissions.

\section{Physical and Chemical Characteristics of Gasolines}

\section{Gasollnes-Conventional, Oxygenated, and Roformulated}

Gasolines are complex mixtures of several hundred types of hydrocarbons. Conventional, oxygenated and reformulated gasolines have most of the same component hydrocarbons, but differ in the relative quantities of the various hydrocarbons and oxygenates they contain. The components in these mixtures range in boiling points from 80 to 437 degrees Fahrenheit. The majority of hydrocarbons have 4 to 12 carbon atoms in their molecular structure (written $\mathrm{C}_{4}, \mathrm{C}_{5}$, etc.) and fall into four general types: paraffins (including the cycloparaffins and branched paraffins), olefins, aromatics, and oxygenated hydrocarbons. Appendix E discusses the basic structure of these types of molecules.

Most of the refinery streams which are now blended into gasoline are produced in refinery processes to create hydrocarbons in the gasoline boiling range with desirable performance characteristics for spark-ignition engines. In the past, the criteria for a gasoline-hydrocarbon mix were driven only by engine performance. Now, evaporative and exhaust emissions also drive the choice of gasoline's hydrocarbon mix. For example, aromatics increase gasoline performance by increasing octane, but these produce more exhaust hydrocarbon, carbon monoxide (CO), and toxic emissions than do other hydrocarbon types. Inclusion of oxygenated hydrocarbons has been shown to reduce $\mathrm{CO}$ emissions. Oxygenates are also high-octane components; thus, adding oxygenates reduces the need for aromatics to meet octane requirements.

\section{Oxygenated Gasoline}

Oxygenated gasoline is created by adding oxygenates. Ether oxygenates are MTBE, ETBE, and tertiary amyl methyl ether (TAME). Alcohol oxygenates are ethanol, methanol, and tertiary butyl alcohol (TBA). Of these oxygenates, only MTBE and ethanol are in widespread use. In order to meet the requirement for 2.7 percent oxygen by weight, about 15 percent MTBE or 7.7 percent ethanol (by volume) must be added to gasoline. The difference in volumes is due to differences in oxygen content between the two compounds. Each of these oxygenates affects the characteristics of gasoline differently.

The main characteristics of MTBE and ethanol are shown in Table 27. The ether MTBE has about the same density as gasoline and a vapor pressure in the middle of the range exhibited by other blending components. MTBE is a pure compound, so it has a single boiling point of 131 degrees Fahrenheit. Its blending octane number is very high at $109(\mathrm{R}+\mathrm{M}) / 2$, and its oxygen content is 18.2 percent by weight.

Table 27. Solected Properties of Methyl TertiaryButyl Ether (MTBE) and Ethanol

\begin{tabular}{c|ccc}
\hline Property & MTBE & Ethanol \\
\hline Chemical Formula $\ldots \ldots \ldots \ldots \ldots \ldots$ & $\mathrm{C}_{5} \mathrm{H}_{12} \mathrm{O}$ & $\mathrm{C}_{2} \mathrm{H}_{5} \mathrm{OH}$ \\
Oxygen (weight \%) $\ldots \ldots \ldots \ldots \ldots \ldots$ & 18.2 & 34.7 \\
Density (Ib/gal) $\ldots \ldots \ldots \ldots \ldots \ldots$ & 6.2 & 6.6 \\
Boiling Point ( $\left.{ }^{\circ} \mathrm{F}\right) \ldots \ldots \ldots \ldots \ldots \ldots$ & 131 & 172 \\
Blending RVP (psi) $\ldots \ldots \ldots \ldots \ldots$ & 8 & 18 \\
Blend Octane Number $[(\mathrm{R}+\mathrm{M}) / 2] \ldots$ & 109 & 113 \\
\hline
\end{tabular}

Source: Table 22 and A/cohol Outlook (October 1993), p. 16.

Like MTBE, ethanol is a pure component with a single boiling point of 172 degrees Fahrenheit, and its blending octane number is quite high at 113 (Chapter 6). The oxygen weight content of ethanol is 34.7 percent, almost twice that of MTBE. Alcohols have a much higher blending Reid vapor pressure (RVP) than pure component RVP, which while acceptable with today's oxygenated gasoline requirements, will work against their role in RFG. However, alcohols' affinity to water will be a greater obstacle to supplying the RFG market than will be the RVP impact.

Ether oxygenates, such as MTBE, mix freely with gasoline and can be separated only through distillation. This property permits ethers to be blended at the refinery and shipped by pipeline. This property is not shared by the alcohols. Alcohols' affinity to water prevents ethanol from being blended at the refinery and shipped by pipeline, where the product may come in contact with water.

\footnotetext{
192 "Baseline" fuel and vehicle are defined in the CAAA to be representative of a 1990 gasoline and 1990 model year vehicle.

${ }^{193}$ Toxic emissions are defined in Section 219 of the CAAA for this purpose to be the aggregate emissions of benzene.
} 


\section{Rotormulated Casolino}

The specifications for and methods of certifying RFG were not finalized in the CAAA. Gasoline produced for ozone nonattainment areas after January 1,1995, will be certified as meeting the initial reformulated gasoline requirements if the fuel conforms to certain specifications to meet the mandated reductions in VOCs and toxic emissions. The EPA will use a "simple" model to certify the gasoline in the first several years of the program. From 1998 and beyond, refiners will be required to recertify their gasoline with a "complex" model.

In order to achieve the goals established by the CAAA, the year-round composition of RFG after January 1 , 1995, is required to have:

- Minimum of 2 percent oxygen (by weight)

- Maximum of 1 percent benzene (by volume)

- Adequate detergents to prevent accumulation of deposits in engines and vehicle fuel supply systems

- No heavy metals content (unless waived).

In 1998, the reformulated gasoline composition must achieve reductions in VOCs, $\mathrm{NO}_{\mathrm{x}}$ and toxic emissions using the complex model. This can be done with some combination of:

- Reduced fuel volatility (reduced RVP)

- Addition of oxygenates to achieve the 2.0-percent minimum oxygen content (by weight)

- Reduced benzene and other aromatics

- Reduced olefins

- Reduced sulfur

- Reduced distillation curve (increased E-200 and E-300).

Under the simple model, the initial 15-percent reduction of VOCs will be met mainly by lowering the RVP. Volatility requirements limit RVP to 8.7 or 7.8 , depending on the classification of the ozone nonattainment region. Toxic emission reduction compliance will be dominated by benzene control and RVP control, since the VOC emissions contain toxic emissions.

The complex model will allow refiners to trade off among the olefin content, aromatic content, sulfur content, and distillation, all of which influence emissions of $\mathrm{NO}_{x}, \mathrm{VOCs}$, and toxic compounds.

\section{Fuel Properties of Gasolines}

The major properties of conventional, oxygenated, and reformulated gasolines that govern engine performance are volatility and octane. Performance criteria which gasolines must address include driving range (miles per gallon), cold-start ability, smooth running after warmup, and avoidance of vapor lock. The fuel should also prevent spark plug fouling, filter plugging, and excessive engine wear. While performance criteria are being met, evaporative and exhaust emission requirements cannot be exceeded. The intention behind using oxygenated and reformulated gasolines is to keep engine performance as close to that with conventional gasoline as possible, while reducing emissions. These fuels are to be burned in today's gasoline engines without modifications to the engines.

\section{Volatility}

As indicated in Chapter 6, volatility indicates a fuel's ability to vaporize under different temperature and pressure situations. It is the characteristic that most affects startup engine performance. Improper volatility can cause hesitation, stumbling, and surge. Gasolines must have more volatility in cold weather than in warm in order to both ignite the fuel and run smoothly until the engine is warmed up. In warm weather, volatility must be decreased to prevent excess vapor from forming. Loss of power or stalling is caused by this vapor lock. Higher volatility leads to increased evaporative emissions, so volatility must not only be controlled to meet engine performance characteristics, but also to stay within limits on evaporative enissions.

Gasoline volatility is characterized by RVP and the distillation range as measured by percent of gasoline evaporated over the full gasoline boiling-temperature range. These parameters are adjusted seasonally and geographically to meet different performance criteria and regulatory requirements.

RVP is the vapor pressure of gasoline in pounds per square inch (psi) at 60 degrees Fahrenheit under atmospheric pressure. It is directly correlated to gasoline's ability to deal with the cold-start and vapor lock tendency. When considering a fuel component's impact on the total RVP of gasoline, its blending RVP is the measure of importance. The blending RVP refers to the vapor pressure impact of a component when added to other substances in the gasoline blend. Most alcohols, for example, have a much higher blending RVP than the pure component RVP.

Distillation range characterizes the overall "driveability" of the fuel. The distillation curve represents the percentage of material that evaporates at given temperatures over the boiling range. For example, materials in the front end (low boiling-point end) of the curve affect cold-start capabilities and vapor lock tendencies. 
Operating at low temperatures requires high volatility at the low-temperature range for quick starting; but low volatility is required to prevent vapor lock during high temperatures. To characterize different volatilities from the distillation curve, temperatures are sometimes tabulated for the points at which 10 percent, 50 percent, and 90 percent of the material is evaporated. The "T90" point-the temperature at which 90 percent of the material is vaporized or distilled-indicates the heaviness of the "top" end (high-boiling-point end) of the distillation curve.

As discussed under the physical and chemical characteristics of alcohol fuels, the polar nature of alcohols sometimes creates counterintuitive effects on physical characteristics of gasoline-alcohol blends. RVP for low blends of ethanol and gasoline, such as E-10, is higher than one would expect from the pure component RVPs of ethanol and gasoline alone. Pure ethanol has an RVP of 2.3, but in blends of about 10 percent ethanol, it behaves as though its RVP were 18 (referred to as a blending RVP). It is not until ethanol reaches a point somewhere above 70 percent that the vapor pressure of the blend becomes less than the base gasoline's vapor pressure.

\section{Octane Number}

As stated in Chapter 6, the octane number indicates whether or not a fuel will knock in an engine. Unleaded regular gasoline today has a road octane number $[(R+M) / 2]$ of 87 . Higher octane is available in the 90 to $94(\mathrm{R}+\mathrm{M}) / 2$ range for cars that still knock on the regular unleaded grade.

Each refinery process produces a stream with different hydrocarbon content and properties. These streams are blended together to produce a grade of gasoline that will meet octane, volatility, and other product specifications. The octane depends on the type and volume fraction of the various types of hydrocarbons. Those hydrocarbon types also determine the emission attributes of the fuel.

For straight-chain paraffins, the octane number decreases as the number of carbon atoms increases. For example, propane $\left(\mathrm{C}_{3} \mathrm{H}_{8}\right)$ has an octane number of 106 $(\mathrm{R}+\mathrm{M}) / 2$, while hexane $\left(\mathrm{C}_{6} \mathrm{H}_{14}\right)$ has an octane number of $26(R+M) / 2$. The paraffins produce fewer tailpipe emissions (nonmethane hydrocarbons and $\mathrm{CO}$ ) than other hydrocarbons, and they are less photochemically reactive, and thus less prone to ozone creation.

Isoparaffins have different characteristics than linear paraffins. The $\mathrm{C}_{6}$ isoparaffin isohexane is similar to hexane in chemical structure except for the inclusion of a branched methyl group $\left(\mathrm{CH}_{3}\right)$. The octane numbers for isoparaffins are generally higher than for the straight-chain paraffins. For example, the octane number for isohexane is $73(R+M) / 2$ versus $26(R+M) / 2$ for hexane.

The $\mathrm{C}_{6}$ olefin (hexene) also has a higher octane number than the paraffin hexane: $70(R+M) / 2$ for the olefin versus 26 for the paraffin. The olefins are more reactive and hence have a greater tendency for ozone formation than the paraffins. It was generally believed that the olefins would also be associated with higher nonmethane hydrocarbon and $\mathrm{CO}$ tailpipe emissions, but recent results have not shown that to be true. ${ }^{194}$

The $C_{6}$ aromatic is benzene, which has an octane number of $106(R+M) / 2$. Octane numbers are very high for aromatics, which makes them attractive for gasoline engine performance. However, as the aromatic content of gasoline increases, hydrocarbon and $\mathrm{CO}$ tailpipe emissions also increase.

The high octane content of MTBE, ethanol, and other oxygenates makes them attractive additions to gasoline from an antiknock perspective. MTBE, for example, was being used as an octane enhancer before its current use as an oxygenate.

\section{Energy Content and Other Properties}

Energy content of gasoline does not vary much between gasoline grades, but is important when comparing with other fuels. The weight of each fuel and the volume required to produce a mile of travel (which is a function of energy content) are important differences among the crude-based and alternative fuels. Other characteristics of gasoline, such as heat of vaporization and flammability, are discussed in Chapter 6. When oxygenate content is increased in a fuel, aromatic content is decreased, and the result is a gasoline with slightly decreased energy content-since the oxygenates are at the lower range of blending component energy content, and aromatics are at the high end.

\footnotetext{
${ }^{194}$ Richard A. Corbett, "Auto/Oil Progressing Toward Cleaner Fuel Compositions," Fuel Reformulation (Denver, CO: Hart Publications, Inc., September/October 1993), p. 46.
} 


\section{Conventional, Oxygenated, and Reformulated Gasoline Production}

Among the fuels covered in this document, gasolines are the most complex chemically and have one of the most complex production processes. Although this complexity contributes to cost, it also provides flexibility in adjusting fuel specifications to meet different performance and emission standards. The following is a brief summary of the major refinery process steps that influence gasoline's composition and thus its properties.

The streams blended to produce gasoline in a refinery come from a variety of distillation and conversion processes. In addition, butanes and oxygenates are blending components frequently purchased from outside sources to provide added feedstock and blending components for gasoline. The most important of the gasoline component production processes are catalytic reforming, catalytic cracking, alkylation and isomeriza- tion (Figure 6). In 1990, reforming contributed 32 percent by volume to the gasoline pool, fluid catalytic cracking 35 percent, alkylation 12 percent, and isomerization 5 percent. In addition, 9 percent of gasoline was derived from light straight run and other miscellaneous streams. MTBE contributed 2 percent to the pool, and butane, which was added for octane enhancements and volatility, 5 percent.

The first step in the refinery process is atmospheric distillation, where crude oil is distilled into different hydrocarbon fractions. Following distillation, the major processes either "crack" (break apart) hydrocarbon molecules (thermal and fluid catalytic cracking), combine hydrocarbon molecules (alkylation), rearrange molecules (reforming, isomerization), or treat the hydrocarbon mixtures to remove substances such as sulfur (hydrotreating). These processes differ dramatically in the types of hydrocarbon compounds produced (Table 28).

\section{Figure 6. Simplifled Refinery Conflguration}

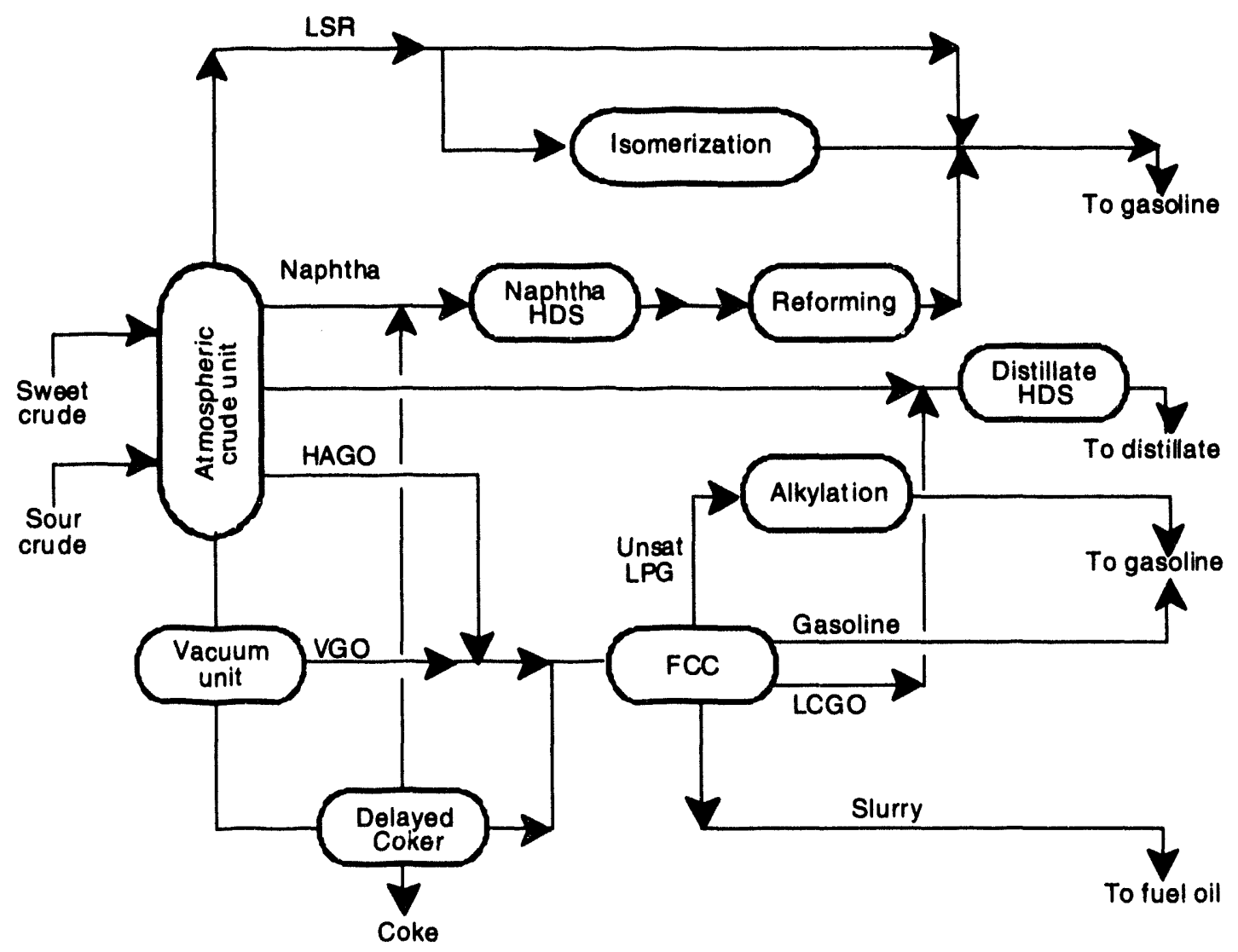

Notes: LSR, light straight run; VGO, vacuum gas oil; HAGO, heavy atmospheric gas oil; HDS, hydrodesulfurization; LCGO, light catalytic gas oil; FCC, fluid catalytic cracking.

Source: James H. Gary and Glenn E. Handwerk, Petroleum Refinery (New York: Marcel Dekker, Inc., 1975), p. 3. 
Table 28. Examples of Component Streams for Gasoline

\begin{tabular}{|c|c|c|}
\hline Stream & $\begin{array}{c}\text { Bolling } \\
\text { Range } \\
\text { ( }{ }^{\circ} \text { F) }\end{array}$ & $\begin{array}{l}\text { Production } \\
\text { Process }\end{array}$ \\
\hline \multicolumn{3}{|l|}{ Paraffinic } \\
\hline Butane . & 32 & Distillation \\
\hline Isopentane . . . . . . . & 81 & Distillation \\
\hline Alkylate .... & $105-300$ & Alkylation \\
\hline Isomerate . . . . . . & $105-160$ & Isomerization \\
\hline Straight-run Naphtha & $85-212$ & Distillation \\
\hline Hydrocrackate .... & $105-390$ & Hydrocracking \\
\hline \multicolumn{3}{|l|}{ Olofinic } \\
\hline Catalytic Naphtha & 103-390 & Catalytic Cracking \\
\hline \multicolumn{3}{|l|}{ Aromatic } \\
\hline Catalytic Reformate & $105-390$ & Catalytic Reforming \\
\hline
\end{tabular}

Source: James G. Speight, Chemistry and Technology of Petroleum (New York: Marcel Dekker, 1980), p. 427.

\section{Catalytic Reforming}

The principal objective of the reforming process is to convert nonaromatic hydrocarbons in the gasoline (or naphtha) boiling range to aromatics. This is accomplished using a special catalyst and high temperatures. As reforming severity is increased, aromatic content increases and reformate yield decreases. For example, for a typical feedstock, increasing the reformer severity from 90 to 100 (product Research Octane Number) reduces the product yield from 85 to 78 percent (by volume) reformate. ${ }^{195}$ The other products produced are light hydrocarbons, such as hydrogen, methane, ethane, propane and butane. The change produced in the hydrocarbon composition of the feedstock is illustrated in Table 29.

\section{Table 29. Change in Composition of Feedstock} in Reforming

\begin{tabular}{c|c|c}
\hline Component & $\begin{array}{c}\text { Volume } \\
\text { Percent } \\
\text { Feedstock }\end{array}$ & $\begin{array}{c}\text { Volume Percent } \\
\text { Product } \\
\text { (Reformate) }\end{array}$ \\
\hline Paraffins . . . . . & $45-55$ & $30-50$ \\
Olefins ... . . . & $0-2$ & 0 \\
Naphthenes ... & $30-40$ & $5-10$ \\
Aromatics .... . & $5-10$ & $45-60$ \\
\hline
\end{tabular}

Source: James H.Gary and Glenn E. Handwerk, Petroleum Refining (New York: Marcel Dekker, Inc., 1975), p. 65.

\section{Alkylation}

In attempting to maximize the volume of gasoline created from crude oil, alkylation was devised to combine the light olefins from catalytic cracking that are too low in boiling point to add to gasoline blends (e.g., butylenes and propylene) into larger, branched, paraffin molecules. In the alkylation process using hydrofluoric or sulfuric acid as catalysts, isoparaffins with tertiary carbon atoms, such as isobutane, react with olefins. The final product, alkylate, is blended into the gasoline product.

\section{Fluid Catalytic Cracking}

The objective of refinery cracking processes is to convert heavy cuts of crude oil to lighter materials. In the fluid catalytic cracking (FCC) process, a heavy oil stream boiling in the 650 to 1,000 degree Fahrenheit range is cracked or broken down into light boiling material, much of which falls into the gasoline boiling range. The process uses a catalyst and temperatures from 900 to 1,000 degrees Fahrenheit to break down the large molecules into smaller ones. The FCC unit not only produces naphtha for gasoline blending, but also light cycle oil (diesel, home heating), light gases, heavy oil (bunker, fuel oil) and coke. ${ }^{196}$ Typical volume yields might be 50 percent for FCC gasoline, 20 percent for light cycle oil, and 7 percent for heavy oil.

Gasoline produced from the FCC process varies in hydrocarbon composition because of variation in feedstock, catalysts and operating conditions. The lower boiling portions tend to have mostly olefins and paraffins, while at the upper end of the boiling range, the aromatic content is high.

\section{Isomerization}

Isomerization is a process in which straight-chained normal paraffins are converted to branched isoparaffins with the same chemical composition. The refinery stream commonly put into the isomerization unit is the light-naphtha stream (straight run gasoline), which is primarily $\mathrm{C}_{5} \mathrm{~s}$ and $\mathrm{C}_{6} \mathrm{~s}$. Converting normal paraffins to isoparaffins significantly improves the octane quality of this stream. The approximate improvement in octane number is 20 , increasing the research octane number from 72 to 92 . The output of the isomerization unit, isomerate, is then blended into the final product.

\footnotetext{
${ }^{195}$ Conald M. Little, Catalytic Reforming (Tulsa, OK: PennWell Publishing Company, 1985), p. 80.

${ }^{196}$ The coke is deposited on the catalyst and subsequently is burned off to produce process heat.
} 


\section{MTBE and Other Ethers}

Although octane levels are enhanced through reforming, isomerization, and so forth, components such as MTBE can be added to enhance octane content and to meet oxygenated gasoline requirements. MTBE is an ether produced by combining methanol with the tertiary olefin, isobutylene, as follows:

$$
\text { Isobutylene + Methanol } \rightarrow \text { MTBE . }
$$

Methanol is made from synthesis gas (mixture of $\mathrm{CO}$ and hydrogen), which is usually produced from natural gas, but can also be produced from coal in the coal gasification process (see "Methanol Production" in Chapter 6.) The main distinctions among MTBE production processes are the ways in which isobutylene is produced. Isobutylene is produced in a limited quantity as a byproduct of catalytic cracking in the refinery and of petrochemical ethylene cracking. Isobutylene is also produced by isomerizing butane, which is part of the gas liquids stream separated from natural gas during its processing. Beginning with butane is a more expensive route to MTBE but is needed to meet MTBE demand.

Other ethers, such as TAME and ETBE, can be produced and used. TAME is the ether produced by using methanol and isoamylene, a five-carbon olefin, rather than the $C_{4}$ olefin isobutylene used to make MTBE. ETBE is produced from ethanol and isobutylene. Neither TAME nor ETBE is as economically attractive as MTBE.

\section{Ethanol and Other Alcohols}

Ethanol is the primary alcohol used in producing oxygenated gasoline, generally made from biomass by fermentation. In the United States, the biomass feedstock is principally corn. Because of ethanol's water affinity, it is usually added to the gasoline product in the market region rather than at the refinery (see "Ethanol Production" in Chapter 6.) With current production economics, ethanol has only been a competitive gasoline component through tax subsidies. Other alcohol oxygenates, such as methanol and TBA, are not as economically attractive as ethanol.

\section{Blending}

Finally, the streams from these various processes and the additives are blended to make gasoline. As indicated earlier, streams from the reforming and FCC units composed 67 volume percent of the gasoline pool in 1990; alkylation contributed 12 percent; isomerization, 5 percent; MTBE and butanes, 7 percent; and light straight run and other miscellaneous streams contributed the remaining 9 percent.

The blending process attempts to meet various performance criteria as outlined previously. Table 30 shows some of the differences in hydrocarbon content, volatility, and octane number of the key streams.

Table 30. Blending Stream Propertles

\begin{tabular}{|c|c|c|c|c|c|c|c|}
\hline \multirow[b]{2}{*}{ Fuel or Additive } & \multirow{2}{*}{$\begin{array}{l}\text { Aromatics } \\
\text { (Volume \%) }\end{array}$} & \multirow{2}{*}{$\begin{array}{c}\text { Olefins } \\
\text { (Volume \%) }\end{array}$} & \multirow[b]{2}{*}{$(R+M) / 2$} & \multirow{2}{*}{$\begin{array}{l}\text { Blending } \\
\text { RVP }\end{array}$} & \multicolumn{3}{|c|}{ ASTM Distillation Temperature $\left({ }^{\circ} \mathrm{F}\right)^{1}$} \\
\hline & & & & & $10 \%$ & $\mathbf{5 0} \%$ & $90 \%$ \\
\hline FCC Gasoline .......... & $22-33$ & 30 & 87 & 6 & 152 & 228 & 374 \\
\hline Reformate .. & $45-70$ & 0 & $90-100$ & 5 & 194 & 270 & 356 \\
\hline Light Straight Aun . & $0-4$ & -- & $60-70$ & 11 & 90 & 140 & 185 \\
\hline Normal Butane $\mathrm{N}-\mathrm{C}_{4}$ & 0 & 0 & 92 & 55 & 31 & -- & -- \\
\hline Isomerate . . . . . . . & $<2$ & 0 & $84-88$ & 12 & -- & - & -- \\
\hline Alkylate ..... & 0 & 0 & 93 & 7 & 120 & 219 & 296 \\
\hline MTBE $\ldots \ldots \ldots \ldots \ldots$ & 0 & 0 & 109 & 8 & 131 & -- & -- \\
\hline$\ldots \ldots \ldots \ldots \ldots$ & 0 & 0 & 113 & 18 & 173 & -- & -- \\
\hline
\end{tabular}

'Percentage points for mixtures and boiling points for pure components.

Sources: W.E. Morris, "Gasoline Combustion in No-Lead Era," Oil and Gas Journal (March 18, 1985), p. 100. G. Unzelman, "Refining Options and Gasoline Composition 2000," Presentation at NPRA 1992 Annual Refinery Meeting, March 22-24, New Orleans, LA. W.J. Piel and R.X. Thomas, "Oxygenates for Reformulated Gasoline," Hydrocarbon Processing, Vol 69, No. 7 (July 1990). Estimates by OnLocation, Inc. 


\section{Oxygenated Gasoline-Process Changes}

When oxygenated gasoline is produced, including an ether or alcohol causes changes in refinery operations and in the volume and character of the other blend components. Oxygenates are high-octane blending components. To meet the oxygen requirement of 2.7 percent by weight, the gasoline blend must contain 15 percent MTBE by volume. This represents a substantial increase in MTBE use over that required when it is used only as an octane enhancer. As a consequence, the refiner can reduce the severity of reforming (thus reducing octane number of reformate), which increases reformate yield and reduces aromatic content. Refiners can also blend in more light straight run gasoline.

\section{Reformulated Gasoline-Process Changes}

When refiners begin to produce the reformulated gasoline required in 1995, processes will change further. Oxygenate use will increase as oxygenated and reformulated gasolines are required in broader geographic areas and over a longer portion of the year. Additional vapor pressure reduction will require that less butane be added to gasoline. Sulfur content must also be reduced. The major changes facing refiners, however, will be reduction in aromatic and olefin content.

Isomerate and alkylate are very attractive components from the emissions and performance perspectives, and their use will increase. Reductions in reformer severity in making oxygenated gasoline will continue. Also, the front end (low boiling components) of the reformer feed will be eliminated to reduce benzene in the final product.

Changes in the FCC operation will be quite significant. FCC severity and new catalysts will be used to increase olefin production. Olefins will be used for producing both MTBE and alkylate. Reducing sulfur in the gasoline product will require hydrotreating of the feed or of the gasoline itself. The heavy end of FCC gasoline will be excluded from reformulated gasoline both because of the requirement to reduce T90 and because of its high aromatic content. How to dispose of heavy-end material represents one of the challenges facing the refiner.

\section{Distribution of Gasolines}

Gasoline travels through an extensive distribution and marketing chain beginning at the refineries (Figure 7).
Refineries are clustered on the Gulf Coast, the East Coast, and West Coast, where they can receive crude oil from both international and domestic locations. While refineries serve some large industrial and utility customers directly, product is usually distributed by pipeline or barge to large terminals closer to the end user. The top five refiners each operate several hundred of these primary terminals. From these pipeline and marketing terminals, some product is again sent directly to large industrial and utility users, but most is sent to bulk storage facilities which act as hubs for final distribution to retail outlets and large customers. Product is moved to the bulk plants and on to retail outlets or wholesale customers by tank trucks, which typically haul from 5,000 to 10,000 gallons each.

Pipelines are the cheapest means of transportation on a cents-per-mile-per-gallon basis, followed by barge and then truck (Table 31). Transportation cost becomes important when gasoline is competing with other alternative fuels that do not have an efficient delivery infrastructure. Trucking costs (cents per mile per gallon) are 25 times as high as pipeline costs. The economics for other fuels quickly become unattractive compared with gasoline if they are unable to use cheap pipeline delivery systems. While terminal costs are generally not significant compared with delivery costs, storage is an important part of the delivery system in assuring that product is available when needed.

The pervasive need for gasoline requires many retail outlets. A typical gasoline station has two or three pump islands, each with three pumps and six nozzles. A gasoline station will also have three underground storage tanks to handle three grades of gasoline (regular, premium, and some mid-grade).

The total number of gasoline retail outlets in the United States as surveyed by National Petroleum News was 202,443 in 1992. Average gasoline sales per outlet were estimated to be almost 75,000 gallons per month. ${ }^{197}$

There are four categories of gasoline retail outlets: pumper, service station, convenience store, and other (Table 32). Pumper stations sell the most volume per station, averaging 50 percent higher than service stations. In both service station and pumper categories, the figures show an economizing trend to increase volume per station. Further emphasizing the high volume/ outlet strategy, pumper stations are gaining market share, while service stations are losing. Convenience stores, while comprising less than 10 percent of the market, are a modestly growing segment-moving from

${ }^{197}$ National Petroleum News, Vol. 85, No. 7 (Mid-June 1993), pp. 130, 133. 
Figure 7. Distrlbution of Refined Petroleum Products

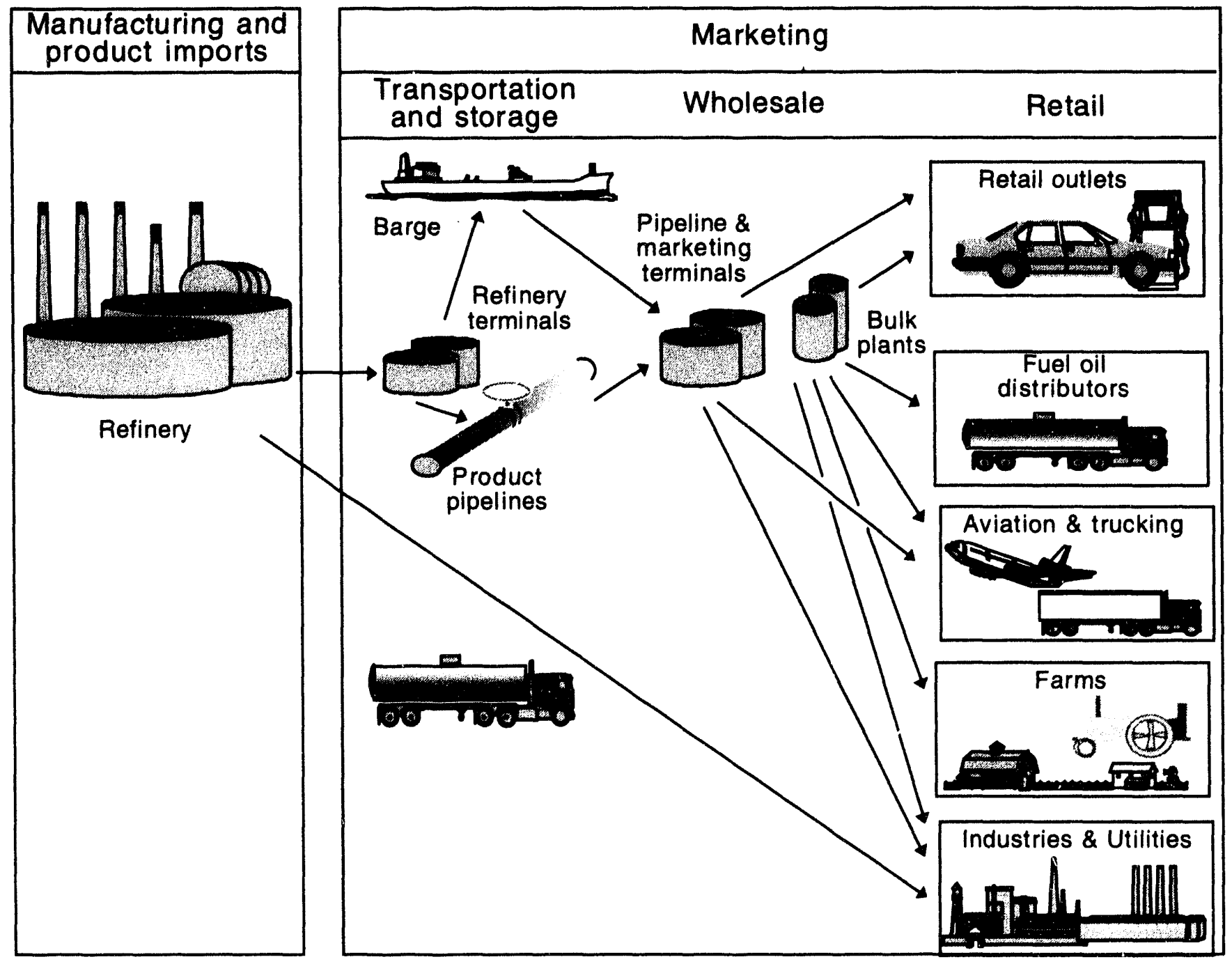

Table 31. Illustrative Cost to Transport Gasoline from the U.S. Gulf Coast to a Boston Service Station

\begin{tabular}{|c|c|c|c|}
\hline \multirow[b]{2}{*}{ Transport Segment } & \multicolumn{3}{|c|}{ Transport Cost } \\
\hline & Number of Mlles & Cents per Gallon & Conts per Mile per Gallon \\
\hline Pipeline to NY Harbor . . . . . . & 1,500 & 2.2 & 0.0015 \\
\hline Terminal Cost (Incremental) . . & -- & 0.1 & -- \\
\hline Barge to Boston $\ldots \ldots \ldots$ & 250 & 1.1 & 0.0044 \\
\hline Terminal Cost (Incremental) . . & -. & 0.1 & -- \\
\hline Truck to Service Station & 40 & 1.5 & 0.0375 \\
\hline Total $\ldots \ldots \ldots \ldots \ldots \ldots$ & 1,790 & 5.0 & 0.0028 \\
\hline
\end{tabular}

Source: National Petroleum Council, S\&T System Dynamics, Petroleum Storage and Transportation, Volume II (Washington, DC, April 1989), p. 65. 
Table 32. U.S. Gasoline Shares by Retall Category, 1988-1992

\begin{tabular}{|c|c|c|c|c|}
\hline Catogory & Year & $\begin{array}{c}\text { Percent of } \\
\text { Number of Outlets }\end{array}$ & $\begin{array}{c}\text { Percent of } \\
\text { Volume }\end{array}$ & $\begin{array}{l}\text { Average Monthly } \\
\text { Gallons per Outlet }\end{array}$ \\
\hline \multirow[t]{5}{*}{ Service Stations } & 1988 & 42.2 & 39.3 & 58,021 \\
\hline & 1989 & 39.8 & 37.7 & 61,669 \\
\hline & 1990 & 38.4 & 36.4 & 62,479 \\
\hline & 1991 & 38.0 & 35.6 & 68,972 \\
\hline & 1992 & 36.9 & 34.9 & 70,398 \\
\hline \multirow[t]{5}{*}{ Pumpers } & 1988 & 30.9 & 50.0 & 108,226 \\
\hline & 1989 & 32.3 & 51.2 & 110,898 \\
\hline & 1990 & 33.2 & 52.5 & 112,230 \\
\hline & 1991 & 33.9 & 53.6 & 115,107 \\
\hline & 1992 & 34.9 & 54.3 & 115,947 \\
\hline \multirow[t]{5}{*}{ Convenience Stores } & 1988 & 16.3 & 7.7 & 31,387 \\
\hline & 1989 & 17.4 & 8.5 & 33,948 \\
\hline & 1990 & 18.3 & 8.5 & 32,220 \\
\hline & 1991 & 18.5 & 8.4 & 33,357 \\
\hline & 1992 & 18.8 & 8.5 & 33,728 \\
\hline \multirow[t]{5}{*}{ Others } & 1988 & 10.6 & 3.0 & 18,552 \\
\hline & 1989 & 10.5 & 2.6 & 17,631 \\
\hline & 1990 & 10.1 & 2.6 & 18,524 \\
\hline & 1991 & 9.6 & 2.4 & 18,389 \\
\hline & 1992 & 9.4 & 2.3 & 18,316 \\
\hline \multirow[t]{5}{*}{ Total } & 1988 & 100.0 & 100.0 & 66,740 \\
\hline & 1989 & 100.0 & 100.0 & 70,023 \\
\hline & 1990 & 100.0 & 100.0 & 69,036 \\
\hline & 1991 & 100.0 & 100.0 & 73,225 \\
\hline & 1992 & 100.0 & 100.0 & $\mathbf{7 4 , 4 9 5}$ \\
\hline
\end{tabular}

Source: National Petroleum News, Vol. 85, No. 7 (Mid-June 1993), pp. 132-133.

a 7.7-percent share of volume sold in 1988 to 8.5 percent in 1992.

Another gasoline marketing trend is the move to selfservice. The self-service market share increased from 22 percent in 1975 to 86 percent in $1992 .{ }^{198}$ The trend indicates that the shortened time for getting in and out of the gas station and the price difference between selfserve and full-serve sales kept customers coming to self-serve. In order to compete with gasoline, alternative fuels will also need to capture economies of scale, decrease costs, and satisfy the customer's need for quick turnaround time.

Commercial fleet vehicles often use company refueling facilities. These centralized, large-volume refueling facilities are a natural penetration point for new fuels that cannot easily use the established fuel distribution system.

Oxygenated and reformulated gasoline follow the same distribution and market paths as traditional gasoline. The only concern that arose prior to the first oxygenated gasoline season-and that will continue to be a concern-is the adequacy of storage to deal with an increasing array of specialized products. In addition, ethanol has a high affinity to water and thus cannot be blended and shipped through the existing pipeline system, which usually contains some water. As a result, ethanol is shipped separately and blended at terminals, as discussed in Chapter 6. These infrastructure issues are minor compared with the infrastructure issues facing alternative fuels.

\footnotetext{
${ }^{198}$ National Petroleum News, Vol. 85, No. 7, p. 138, citing Amoco Oil Co., Market Monitoring Report, Vol XXI, No. 1, January $29,1993$.
} 


\section{Diesel}

\section{Overview}

Diesel fuel, like gasoline, is derived from crude oil and is the second largest transportation fuel used today. Diesel serves primarily a commercial heavy-duty fleet vehicle market, and as such, is a prime target for alternative fuel substitution. As will be described in more detail in this section, diesel has very different combustion characteristics than gasoline or the alternative fuels. Diesel engines (compression-ignition engines) have to be modified significantly to be able to burn most pure alternative fuels. These modifications are being developed and tested.

Diesel can also be burned in combination with alternative fuels. For example, biodiesel (fuel derived from oilbearing plants) will likely be used initially as an addition to diesel fuel in small amounts to reduce emis sions. Other fuels such as LPG and CNG are being studied for use with diesel. This section describes the basic characteristics of diesel fuel to help the reader understand the complexities of replacing this fuel.

\section{Physical and Chemical Properties of Diesel}

Like gasoline, diesel fuel is also a complex mixture of hydrocarbons, but the components fall into higher boiling ranges. The diesel component mixture boils between 370 and 650 degrees Fahrenheit (versus 80 to 437 degrees Fahrenheit for gasoline), which affects its engine performance and emission characteristics. Currently, U.S. diesel fuel is processed from crude oil in refineries.

As expected from the higher boiling range of diesel components, evaporative emissions are not as much of a concern for diesel as for gasoline. Tailpipe emissions, however, are a problem, but they differ from those of gasoline. Diesel engines are more efficient than gasoline engines and emit lower rates of hydrocarbons and $\mathrm{CO}$. Diesel engines also emit lower nitrogen oxides since they operate at lower temperatures than gasoline engines. Particulates, however, are a special concern for diesel fuel in compression-ignition engines. Since diesel has more sulfur (about 90 times that of gasoline) and heavier hydrocarbons (particularly aromatics) which do not burn easily, it tends to produce particulates. ${ }^{199}$

\section{Fuel Properties of Dlesel}

\section{Volatility}

Diesel has a very low Reid Vapor Pressure (about 0.2 versus 8-15 for gasoline) which is consistent with the high boiling ranges of the fuel's components. Like gasoline, a distillation range is used to assure adequate combustion performance. Vaporization must occur smoothly from the initial boiling point until all material is vaporized.

\section{Octane Number}

Diesel has a very low octane number, but for compression-ignition engines, cetane number is the measure of interest.

\section{Cetane Number}

The most important engine performance property of diesel is the cetane number, which is a measure of the ease with which fuel will self-ignite under compression. The delay between the time the fuel hits the hot compressed air and when it ignites depends to a large extent on hydrocarbon composition. The higher the cetane number, the shorter the ignition delay and the better the engine performance. Cetane number is highest for linear paraffins, and lowest for aromatics as shown below:

\section{Fuel Component Contribution to Cetane Number}

Aro- Naph- Branched Linear Branched Linear
matics thenes Olefins Olefins Paraffins Paraffins

A high octane number, desirable for gasoline, means high aromatics and low linear paraffins, whereas the opposite is true for cetane numbers. Higher aromatic content means a lower cetane number and poorer diesel engine performance, as well as increased particulate formation.

In spark-ignition engines, aromatics are good for engine performance but bad for emissions. In compressionignition engines, aromatics are bad for both performance and emissions. Thus, in the case of diesel, there is no tradeoff between performance and emissions regarding aromatics.

\footnotetext{
${ }^{199}$ Adam Seymour, Refining and Reformulation: The Challenge of Green Motor Fuels, Oxtord Institute for Energy Studies (Oxford, UK: Aldgate Press, 1992), pp. 77-79.
} 
Low cetane number and associated long ignition delay cause rough engine operation, misfiring, and incomplete combustion in a cold engine at low temperatures, resulting in power loss and exhaust smoke.

\section{Energy Density}

Diesel has the highest energy density of any of the fuels discussed in this report. Energy density is directly proportional to the mass density of diesel fuel, which in turn is related to the specific compounds composing the fuel.

\section{Flashpoint}

Flashpoint indicates the limiting temperature at which a fuel can be handled without danger of fire. At the flash point, fuel vapors form above the fuel surface in sufficient quantities for ignition to occur in the presence of an open flame. Diesel fuel has the highest flashpoint of any fuel being discussed, implying a higher safety margin in terms of handling. By most fire-safety measures, diesel is a safer fuel than gasoline or the other spark-ignition fuels being discussed.

\section{Other Properties}

The following properties are not major issues with the spark-ignition fuels being reviewed. They are, however, important considerations in producing a diesel fuel that performs well.

Viscosity. Viscosity affects a fuel's lubricating properties and the degree of "atomization" when it is injected into the cylinders. Diesel-engine fuel-injector pumps need fuel with the appropriate "body" or viscosity to operate properly, and fuel atomization directly impacts combustion of the fuel.

Cloud/Pour Points. These are low-temperature performance measures. The pour point is the temperature at which fuel ceases to flow. As the temperature nears the pour point, fuel becomes more difficult to pump. Pour point is a function of the molecular structure of the fuel components. Naphthenes tend to have low pour points, while paraffins (high cetane) have high ones. The cloud point is somewhat above the pour point (usually 5-10 degrees Fahrenheit above). At this temperature, the fuel becomes cloudy because wax crystals form that can block fuel filters.

Sulfur Content. Sulfur-containing compounds in fuel affect the emissions of sulfur oxides and can cause excessive corrosion from the combustion products. Sulfur content can also affect fuel lubricating properties, and in conjunction with aromatics, tends to increase particulates from compression-ignition engines.

Carbon Residue. Carbon residue indicates the tendency for carbonaceous deposits to form during combustion. Such deposits can impair fuel-injector operations. Carbon residue also contributes to particulate emissions.

Water and Sediment. These are a measure of the cleanliness of the fuel storage and handling system. Water can cause ice crystals to form on filters at low temperatures, as well as corrode fuel pumps and injectors.

Color. This is an indication of contamination or degradation during storage.

\section{Diesel Production}

Diesel fuel is produced from crude oil in U.S. refineries. It is produced from the boiling range of material referred to as middle distillates, which includes No. 2 fuel oil, used primarily as a residential furnace fuel for home heating. Diesel and No. 2 differ only in their additives.

The highest quality diesel components (high cetane value) come from the primary distillation of crude in the atmospheric distillation unit. Other refinery sources of diesel blending components are from cracking operations, especially the fluid catalytic cracking unit and the coker. Both of these units produce diesel boiling range material by cracking heavier, higher molecular weight feedstocks into components, some of which fall into the diesel boiling range. The fluid catalytic cracking process employs heat and catalysts to achieve the cracking reactions. Coking is strictly a thermal cracking process. When the petroleum is cracked, the products typically contain more aromatics and olefins than found in the feedstocks. If hydrogen is also used in the cracking operations (hydrocracking), olefin and aromatic output is diminished. The catalytically cracked and thermally cracked products are also sometimes hydrotreated to improve quality for blending into diesel fuel.

\section{Diesel Distribution}

Diesel follows the same distribution network as gasoline, until delivery to the retail outlets. Retail sales of diesel are governed by the major end-users: large trucks. Diesel is the preferred power source with heavy-duty commercial vehicles because of the fuel efficiency of the engines (about 25 percent more efficient than gasoline engines) and their rugged durability. High initial costs, however, make diesel 
engines less economical for light-duty uses in which fuel economy does not compensate for the initial costs.

Since the major use of highway diesel is in large trucks, most highway diesel is provided through truck stops or trucking company terminals. In 1989, the National Association of Truck-stop Operators estimated that about 70 percent of the diesel was purchased at truck stops. Most of the remainder was supplied at company terminals. ${ }^{200}$

There are between 1,500 and 2,000 full-service truck stops and about 7,000 total locations. ${ }^{201}$ Full-service truck stops sell 500,000 to 1 million gallons per month, and some of the newer centers are reaching 2 million gallons. ${ }^{202}$ The trend has been and continues to be toward larger full-service truckstops that can take advantage of economies of scale and attract truck drivers.

Although the diesel retail outlet system is more concentrated than that for gasoline, it still covers the entire United States and moves over 20 billion gallons of fuel. A new fuel attempting to substitute for diesel that cannot use the existing infrastructure will have to find a way to penetrate and build a system to satisfy customers' refueling requirements.

${ }^{200}$ J.H. Hackworth and A.N. Mann, Market Assessment for Coal-Fired High Speed Diesel Systems, Final Report for Morgantown Energy Technology Center, U.S. Department of Energy, DE-AC21-85MC22012 (Morgantown, WV, August 1990), p. 22.

${ }^{201}$ J.H. Hackworth and A.N. Mann, Market Assessment for Coal-Fired High Speed Diesel Systems, p. 22.

${ }^{202}$ National Petroleum News, Vol. 82, No. 5 (May 1990), p. 33. 


\section{Characteristics of Alternative Fueled Vehicles}

Alternative fueled vehicles (AFVs) include both original equipment manufacturer vehicles and after-market conversions (or retrofitted vehicles). Currently, most AFVs are conversions because the original equipment manufacturers have been reluctant to begin vehicle production for an uncertain market. The big three domestic automakers began producing AFVs for Federal and demonstration fleets in the early 1990s in response to legislative and regulatory pressures and an Executive Order by the President to increase AFV purchases. The "Big 3" produced and sold 4,300 and 11,300 AFVs in 1992 and 1993, respectively.

\section{Vehicles}

Vehicles powered with alternative fuels can be developed from many technologies. In the short- to midterm, most will use the traditional internal-combustion engine. More advanced alternative fuel technologies, such as fuel cells and hybrids, over the longer term, will be added by Federal fleets as they become available at a more moderate cost than current demonstration vehicles. The primary vehicle types considered fall into four classifications: dedicated, bi-fueled, dualfueled, and flexible-fueled.

Dedicated vehicles are built to run exclusively on one alternative fuel, and as a result require fewer components. This design strategy also permits the engine/fuel system to be optimized for the alternative fuel.

Bi-fueled vehicles are capable of operating on either an alternative fuel or a conventional fuel (gasoline or diesel). Vehicles of this type generally have a switch (automatic or manual) which permits operation on either fuel, stored in at least one tank for each fuel. Although this design has more fuel system components than a dedicated vehicle, it allows the operator to use AFVs in an area where the refueling infrastructure is not well developed. Most bi-fueled vehicles use natural gas or LPG and gasoline.

Dual-fueled vehicles, like bi-fueled vehicles, have two fuel systems, but the vehicle can burn both fuels at the same time in the engine combustion chamber.
A flexible-fueled or variable-fueled vehicle has only one fuel tank, containing mixtures of the alternative fuel and gasoline. A sensor determines the percentage of the replacement fuel relative to gasoline and adjusts engine operating characteristics automatically. Until methanol and ethanol become more widely distributed, flexiblefueled vehicles are the preferred option for alcohol-fuel use because they perform quite well using gasoline.

The vehicle components and engine systems of alternative-fueled vehicles will vary depending on: the replacement fuel; whether the vehicle is dedicated, dual-fueled, bi-fueled, or flexible-fueled; and whether the vehicle came from the manufacturer or was the product of a conversion from a conventional vehicle.

\section{Engines}

Most highway vehicles use one of two types of internalcombustion engines: spark ignition (SI, sometimes called Otto ignition or gasoline engines) and compression ignition (called diesel or $\mathrm{Cl}$ engines). These are the basic engine designs for alternative fuels. The mechanics of both engine types are similar in that they both have pistons and cylinders connected to a flywheel by a crankshaft. The crankshaft converts the reciprocating piston movement to the rotary movement needed to power the vehicle's drive train.

Most reciprocating engines operate with a four-stroke cycle: intake stroke, compression stroke, expansion or power stroke, and exhaust stroke. For a spark-ignition engine, the intake stroke begins with the piston at the top of the combustion chamber. As the piston is withdrawn, a fresh mixture of fuel and air is brought into the combustion chamber. The piston then moves back up into the combustion chamber, compressing the fuel/ air mixture, inlet and outlet valves remaining closed. Toward the end of the compression stroke, combustion is initiated with a spark, and cylinder pressure increases rapidly. The power stroke begins when the piston reaches the peak of its compression stroke. Highpressure gases from the combustion push the piston down, forcing the crankshaft to rotate. Combustion must proceed smoothly and progressively across the 
combustion chamber for the engine to work properly. The piston does about five times the work during the power stroke as during the compression stroke. As the piston nears the bottom of its stroke, the exhaust valve opens to begin the exhaust process. The exhaust stroke pushes the remaining burned gases out of the combustion chamber. As the piston nears the top, the inlet valve opens and just as the piston reaches the top, the exhaust valve closes, beginning the cycle again. ${ }^{203}$

The four-stroke cycle for compression-ignition engines is very similar to that of spark-ignition engines. The combustion cycle is the most significant difference between the two engines. In the spark-ignition engine, a fuel-air mixture is introduced during the intake stroke and ignited by an electric spark at the end of the compression stroke. In the compression-ignition engine, only air is introduced during the intake stroke. The air is compressed to a much higher pressure in the compression-ignition engine than is the fuel-air mixture in a spark-ignition engine. When full compression occurs, the fuel (e.g., diesel) is injected into the chamber where heat generated by the highly compressed air causes it to ignite.

Spark-ignition and compression-ignition engine types require different fuel characteristics to operate properly. As discussed in Chapter 7, the properties of fuels that will combust without a spark under the high pressure and temperature conditions of a compression-ignition engine are different from the desirable properties of fuels used in spark-ignition engines. The alternative fuels have characteristics well suited for spark-ignition engines.

The higher pressures and temperatures of the diesel engine require a heavier and more costly engine than a spark-ignition engine of the same power output. However, the same higher temperatures and pressures allow for greater efficiencies in diesel engines. Thus, there is a tradeoff between up-front cost and operating cost. In addition, the heavy compression-ignition engines can last longer between major overhauls. These properties make them particularly desirable for commercial transport applications, while spark-ignition engines are generally preferred for private vehicle and other lightduty vehicle applications.

\section{Vehicle/Englne Systems}

\section{Alcohol-Fueled Vehicles}

AFVs, including near-neat alcohol vehicles, are being used to gain environmental benefits and enhance energy security by using a nonpetroleum-based fuel. However, these vehicles have some disadvantages which offset some of the benefits.

Fuel Storage. Alcohol corrodes lead-plated fuel tanks; magnesium, copper, lead, zinc, and aluminum parts; and some synthetic gaskets. Hence, alcohol-compatible vehicles require special-material lines, hoses, and valves that resist corrosion. Supplementary components for flexible-fueled vehicles include: a flame arrester to prevent sparks from entering the fuel tank during refueling; a fuel sensor to determine the amount of alcohol in the fuel; and sometimes, a cold-start system. Since ethanol and methanol have lower energy densities per unit volume than gasoline, larger fuel tanks are required, or vehicle range is reduced.

Engine Systems. Since alcohol fuels are high-octane fuels, flexible-fueled engines are optimized with a somewhat advanced ignition timing and an adjusted air/fuel ratio. Overall, neat methanol (100 percent methanol) in spark-ignition engines can provide improved power output and greater thermal efficiencies over gasoline. Emission considerations can result in some limitations to elevated compression ratios and lean combustion permitted by methanol's physical characteristics. Difficulty in cold starts and warmup misfiring are methanol's major performance problems, but solutions are being developed to deal with these issues.

Neat methanol is best suited for spark-ignition engines. Methanol has a high octane value, and hence has a correspondingly low cetane value (somewhere below 15, versus 40-55 for diesel). ${ }^{204}$ In addition, methanol fails to provide adequate lubrication to the highpressure pumps used to inject fuel into the compressed air in the combustion chamber of a compression engine. These characteristics make neat methanol alone unsuitable for compression-ignition engine use, but various means are available to modify either the engine or the fuel. For example, compression-ignition engines have

\footnotetext{
${ }^{203}$ John B. Heywood, Anne Duffy, and John M. Morriss, Internal Combustion Engine Fundamentals (New York, NY: McGraw-Hill, 1988), pp. 9-19, 25-31.

${ }^{204}$ Frank Black, "An Overview of the Technical Implications of Methanol and Ethanol as Highway Motor Vehicle Fuels," Society of Automotive Engineers (SAE), Paper Number 912413 (Warrendale, PA, 1991), p. 4.
} 
been modified for use with methanol by adding an ignition source, such as a glow plug. In order to address some of the spark-ignition engine performance problems, methanol is blended with gasoline-mainly to mitigate cold-start and warmup problems. Current spark-ignition engine technology for dedicated methanol fuel use is designed for $\mathrm{M}-85{ }^{205}$ Adding gasoline to methanol also improves flame visibility when the mixture burns and increases energy density over neat methanol.

While adding gasoline can help performance and safety, it detracts slightly from the emissions gains that neat methanol offers. Emission considerations also limit engine efficiency gains that could be obtained from elevated compression ratios and lean fuel mixtures. Even with these considerations, one estimate indicates that dedicated methanol vehicles could obtain an 18percent engine efficiency gain over gasoline engines, while a 6-percent gain could be obtained with flexiblefueled methanol vehicles, which can use mixtures of M-85 and unleaded gasoline. ${ }^{206}$

Engines for flexible-fueled vehicles are being designed for the transition period between now and some future date when advanced vehicle technology will use neat methanol. ${ }^{207}$ These engines must deal with the entire range of gasoline/methanol mixes since a wide range of blends can occur in a tank when gasoline and M-85 are purchased interchangeably. For example, the control system must be able to monitor the fuel composition and carry two sets of calibrations for fuel flow and spark timing-one each for gasoline and methanoland interpolate for the mixtures. Oxygen sensor changes may also be needed to deal with emission control adjustments. ${ }^{208}$

When alcohol fuels are used in flexible-fueled vehicles, they must accommodate the lower octane fuel used, namely gasoline. Consequently, the compression ratio in these vehicles is not usually modified to produce the maximum engine efficiency advantages of $\mathrm{M}-85$ or E-85.
Initial information on using these vehicles tends to support that vehicle engineering for alcohol fuels can be considered to be essentially the same whether ethanol or methanol is used. ${ }^{209}$

Neat ethanol, like neat methanol, can provide improved power output and greater thermal efficiencies over gasoline in spark-ignition engines. Ethanol and methanol have similar antiknock advantages over gasoline, but methanol has a much higher heat of vaporization. The higher heat of vaporization provides more fuel-air mixture cooling, resulting in an increase in fuel mixture density, and thus, higher mass throughput (i.e., more power). This property makes methanol a superior racing fuel. But this same characteristic will give ethanol better driveability and lower emissions of unburned fuel. ${ }^{210}$ (As discussed in Chapter 6, higher heat of vaporization increases cold-start problems, and the denser fuel/air mixture increases unburned fuel.)

An optimized ethanol engine could exhibit a theoretical efficiency gain of 15 percent over an optimized gasoline engine. But theoretical efficiencies usually are not fully realized. For example, one test using E-95 showed efficiency improvements of 8 percent when increasing the compression ratio from 8 to 12, while 12-percent improvement was expected from theoretical considerations. ${ }^{211}$

As with methanol, difficulty in cold starts and warmup misfiring are ethanol's major performance problems, and both alcohols have corrosive qualities. Gasoline is added to ethanol to mitigate cold-start and warmup problems and to increase flame visibility. E'hanol blends seem to provide less lubrication to metal parts than methanol blends, but neat ethanol is less prone to severe metal-to-metal wear than neat methanol. ${ }^{212}$ Because ethanol has a high octane number and low cetane number, it is best suited for spark-ignition engines. But, as is the case with methanol, modified diesel-fuel engine use for heavy-duty applications is also possible. ${ }^{213}$

\footnotetext{
${ }^{200}$ Frank Black, "Methanol and Ethanol as Highway Motor Vehicle Fuels," p. 11.

${ }^{206}$ Frank Black, "Methanol and Ethanol as Highway Motor Vehicle Fuels," p. 6.

${ }^{207}$ Frank Black, "Methanol and Ethanol as Highway Motor Vehicle Fuels," p. 11.

${ }^{200}$ U.S. Department of Energy, Office of Policy, Planning and Analysis, Assessments of Costs and Benefits of Flexible and Alternative Fuel Use in the U.S. Transportation Sector. Technical Report Four: Vehicle and Fuel Distribution Requirements, DOE/PE-0095P (Washington, DC, August 1990), p. 12.

${ }^{209}$ California Energy Commission, Cost and Availability of Motor Vehicles and Fuels, AB 234 Report (Sacramento, CA: August 1989), pp. II-20, II-21.

${ }^{210}$ American Petroleum Institute, Alcohols and Ethers, 2nd edition, Publication Number 4261 (Washington, DC, July 1988 ), p. 54.

${ }^{211}$ Jerry E. Sinor and Brent K. Bailey, "Current and Potential Future Performance of Ethanol Fuels," Society of Automotive Engineers (SAE), Paper No. 930376 (Warrendale, PA, 1993), p. 87.

${ }^{212}$ Frank Black, "Methanol and Ethanol as Highway Motor Vehicle Fuels," p. 8.

${ }^{213}$ Frank Black, "Methanol and Ethanol as Highway Motor Vehicle Fuels," p. 93.
} 


\section{Liquefled Petroleum Gas Vehicles}

While original equipment manufacturers provided LPGpowered vehicles in the past, no manufacturer is currently producing a light-duty passenger vehicle for sale in the United States, and only one is manufacturing heavy-duty truck engines for the United States. ${ }^{214}$ Most light-duty LPG vehicles today are retrofits or after-market conversions, which have been commercially available for 60 years. ${ }^{215}$ A conversion includes a high-strength fuel tank added to the vehicle, fuel lock filter/shutoff valve, vaporizer/ regulator, an air-fuel mixer, and a microprocessor for air/fuel ratio control. A dual-fuel system is similar, except gasoline fuel system components are not removed, and a mechanism is installed to switch between the systems. The extra weight of carrying two fuel systems detracts from the efficiency of dual-fueled systems.

Fuel Storage. LPG fuel tanks are made of heavy-gauge steel meeting Federal, State, and local codes to withstand a pressure of 1,000 pounds per square inch (psi). Normal working pressures of the tanks vary depending on the ambient temperatures and the quantity of fuel in the tank. Common operating pressures are in the range of 40 to $170 \mathrm{psi}$, corresponding to temperature ranges of 0 to 90 degrees Fahrenheit. These fuel tanks are furnished with pressure-relief valves that will release the fuel vapors to the atmosphere to prevent tank rupture under unusually high pressure conditions such as in a fire. Because of a 20- to 25-percent energy deficit compared with the same volume of gasoline, LPG requires slightly larger fuel tanks or more frequent fillups in order to maintain an equivalent gasoline range. There is a loss of storage area in vehicles with LPG tanks placed in the trunk. However, frame-mounted tanks can prevent storage area loss. A high-pressure fuel line connects the fuel tank to the pressure regulator, normally located under the hood. Pressure regulators or vaporizers reduce fuel pressure in two stages and transfer heat to the fuel to vaporize the liquid. The weight of propane fuel tanks, when full, is similar to the weight of filled gasoline tanks. Thus, no payload capacity is lost.

Engine Systems. Engine-related modifications that allow more efficient use of LPG include: compression ratio increases; different spark plug type; placement of hard seat inserts under exhaust valves; and a modified intake manifold to eliminate "heating" features for gasoline use during warmup. 216 Most conversions today are done on newer vehicles with fuel-injection gasoline engines that are now constructed with many of the changes mentioned above.

In the past, using LPG in an engine designed for regular gasoline resulted in exhaust and intake valve seat wear; however, engines designed in the 1990s for unleaded gasoline or LPG use different materials to counter wear. ${ }^{217}$ The cleanliness of LPG reduces carbon buildup and oil contamination, thereby reducing wear and lengthening the life of components such as rings and bearings. The high octane in LPG also minimizes wear from engine knock. $^{218}$

Because the fuel is already in a gaseous state, it mixes readily with air to allow for nearly complete combustion (thereby reducing some exhaust emissions such as carbon monoxide) and it has few cold-weather starting problems. This fuel's higher-than-gasoline octane value permits use of higher engine compression ratios than with gasoline, which produces higher power and fuel efficiency. Because LPG has a lower energy density than gasoline, it produces fewer miles per gallon. However, the degree of difference in miles per gallon is a function of the engine modifications and how the vehicle is used. If the engine is unmodified to take advantage of the higher octane value, LPG might provide 15 to 25 percent fewer miles per gallon. For heavyduty applications, this fuel's low cetane value makes it inappropriate for sole use in compression-ignition engines, but large heavy-duty propane engines are becoming available.

\section{Natural Gas Vehicles}

Light-duty vehicles designed to run on natural gas include cars, minivans, and vans-mainly for fleets. Natural gas engines are also being designed and used for buses and other heavy-duty vehicles. A natural gas vehicle contains a high-strength fuel tank, fuel lock filter/shutoff valve, regulator, air-fuel mixer, and a microprocessor for air/fuel ratio control. A dual-fueled system retains the gasoline fuel system components, and a mechanism is installed to switch between the systems. The extra weight of carrying two fuel systems detracts from the efficiency of dual-fueled systems.

\footnotetext{
${ }^{214}$ First Interim Report of the Interagency Commission on Alternative Motor Fuels (Washington, DC, September 30, 1990, pp. 5-18.

${ }^{215}$ First Interim Report of the Interagency Commission on Alternative Motor Fuels, pp. 1-18.

${ }^{216}$ Larry W. Carley, Propane Conversion of Cars, Trucks, and RVs (Tab Books, 1982), pp. 58-88.

${ }^{217}$ R.C. Motta, J.E. Elliot, and T.R. Willsie "The Design and Production of Chrysler Canada's 1987 Propane-Fueled Vehicles," Conference Proceedings, Gaseous Fuels for Transportation I (Vancouver, BC, Hosted by BC Research and Institute of Gas Technology, August 1986).

${ }^{218}$ Larry W. Carley, Propane Conversion of Cars, Trucks, and RVs, p. 40.
} 
Fuel Storage. A CNG vehicle stores gaseous fuel at a pressure of 2,400 to 3,600 psi. Even at a pressure of 3,600 psi, a unit volume of CNG has less than onefourth of the energy content of gasoline, which means a much greater storage requirement for the vehicle.

A cylinder for the storage of pressurized gas, certified by the U.S. DOT or another recognized authority, is required on all CNG vehicles. A typical cylinder is certified to withstand $10,000 \mathrm{psi}$, and is about 10 inches in diameter and 4 feet long. While CNG tanks are filled to the certification pressure of the refueling system $(2,400 \mathrm{psi} ; 3,000 \mathrm{psi}$; or $3,600 \mathrm{psi})$, the equilibrium pressure tends to be 10 to 20 percent lower, thus reducing the driving range further. The original gasoline tank is retained in most converted, dual-fueled CNG vehicles.

CNG tanks are larger and fuel-plus-tank weight is higher than for liquid fuel/tank alternatives; however, research efforts are directed at developing lighter tanks. ${ }^{219}$ Cheaper and lighter natural gas cylinders for school buses, light-, and heavy-duty trucks have been developed. One new cylinder has a cold-drawn aluminum liner that is thinner and lighter than the steel or extruded aluminum typically used. The end of the liner is covered with a low-cost fiberglass that protects the cylinder.

As with LPG vehicles, a refueling port and lines must also be installed on vehicles fueled by CNG. High-pressure fuel lines from the storage cylinder lead to a pressure regulator, which lowers gas pressure in one or two steps. Historically, gaseous fuel systems used simple air-valve/air-fuel mixers to create proper air/ fuel mixtures for combustion. Today's emission limitations require more precision and control. One OEM vehicle, for example, is using a fuel injection system containing an electronic control module that processes information from oxygen sensors (for emissions) and provides signals to adjust the fuel flow both for better performance and for better emissions control. ${ }^{220}$

Most of the prior discussion on CNG applies to liquefied natural gas (LNG). However, the energy density and associated vehicle tank tradeoffs are different from those for CNG. The LNG tanks might be pressurized around 30 psi and hold the liquid at a temperature of around -260 degrees Fahrenheit. Somewhere between two and three times the natural gas can be stored as a liquid onboard than in the compressed state. Also, in the process of liquefying natural gas, some of the substances detrimental to engine performance are removed, such as water and carbon dioxide. ${ }^{221}$

While LNG production is not new, transferring it from a refueling station to a vehicle and vaporizing it en route to an engine are new. Most of today's emphasis in using natural gas is being placed on CNG, but operators are increasingly looking to LNG because of its storage benefits.

Engine Systems. Engine modifications that allow more efficient use of natural gas use include compression ratio increases; different spark plug type; placement of hard seat inserts under exhaust valves; and modification of the intake manifold to eliminate "heating" features for gasoline use during warmup. Most conversions today are done on newer vehicles containing fuelinjection gasoline engines that are now constructed with many of the modifications mentioned above.

Natural gas has a higher octane value than gasoline, with generally good perfornance characteristics. As a gas, it has few cold-start problems. Its octane value allows for use of higher engine compression ratios than can be used with gasoline alone. Higher compression ratios allow for higher power and fuel efficiency. The efficiency and power gains achievable from higher compression ratios help to offset power losses relative to gasoline caused by the lower energy density of natural gas.

Differences in density of natural gas and air keep these two gases from forming a homogeneous mixture when first combined. Fluctuations in the air/fuel mixture can result in an engine misfire. Time and turbulence are needed inside the engine to create a uniform mixture. 222

While the characteristics of natural gas just discussed indicate that an engine designed to improve efficiency and lower carbon monoxide emissions would be a high-compression, lean-burn engine, other characteristics make optimization challenging. For example, leanburn engines can encourage formation of $\mathrm{NO}_{x}$ because excess oxygen is present and the high flame tempcrature of natural gas increases the peak combustion

\footnotetext{
${ }^{219}$ U.S. Department of Transportation, Technical Assistance Brief, Bulletin Number 4 Fall 1992: Clean Air Program.

${ }^{220}$ Richard O. Geiss, William M. Burkmyre, and James W. Lanigan, "Technical Highlights of the Dodge Compressed Natural Gas Ram Van/Wagon," Society of Automotive Engineers (SAE), Paper No. 921551 (Warrendale, PA, 1992), pp. 14-15.

${ }^{221}$ Robert M. Nimocks, "Why Liquify," NGV Resource Guide, Volume 1, p. 117.

${ }^{222}$ William E. Liss and William H. Thrasher, "Natural Gas as a Stationary Engine and Vehicular Fuel," Society of Automotive Engineers (SAE), Paper No. 912064 (Warrendale, PA: 1991), p. 49.
} 
temperature. Nonmethane hydrocarbon emissions are low relative to gasoline since natural gas is predominantly methane. However, total hydrocarbon emissions from natural gas engines can be high because methane is slower to react than other hydrocarbons. Also, the slow flame speed of natural gas in lean-fuel mixtures may prevent complete combustion during the power stroke. ${ }^{23}$

\section{Electric Vehicles}

Since electric vehicles do not require an internal combustion engine, they have no components associated with fuel systems or engines. The main components of electric vehicle power systems consist of: charger, battery pack, motor, controller, converter, and watering cart. Since pure electric vehicles have very short ranges, hybrid vehicles that contain dual systems are being developed for range flexibility, fuel flexibility, and other performance improvements. These hybrid vehicles might contain an internal combustion engine (with its appropriate fuel storage tank) along with the battery; a fuel cell and a battery; a flywheel and a battery; or two complementary batteries. ${ }^{24}$

Fuel Storage. Electricity is unique among the replacement fuels in that it is the basic form of power used to run the vehicle, while the other fuels are a means of storing energy that is released upon combustion. For electric vehicles, energy is stored in the batteries (mainly lead acid today). The electricity produced from the batteries drives an electric motor rather than a combustion engine. When the energy from the battery is discharged, the battery must be recharged using electricity as the external energy source.

Battery development is the most important factor to electric vehicle success. The low energy density of batteries affects range and vehicle weight, making these two features primary targets for technology improvements. A typical battery pack to power a four-passenger car might weigh 1,100 pounds. Given a particular battery, performance can only be improved by reducing vehicle weight. A more powerful motor would only require a larger and heavier battery, thereby countering the additional motor power.

Most of today's electric vehicles require about 30 batteries, which must be replaced every few years. As new vehicles of this type and new battery technology enter the market, battery replacement and vehicle efficiency will improve.
Batteries must be handled carefully during recharging and disposal. Owners must watch for acid leakage and avoid electric shock. When the battery is replaced, it must be disposed of properly. Current batteries and current designs for future batteries contain materials that are harmful and others that are expensive. Battery disposal will be subject to EPA regulations. To minimize the impact of battery disposal in the environment, lead batteries are now being recycled. This procedure will no doubt continue in the future as more electric vehicles are put into operation.

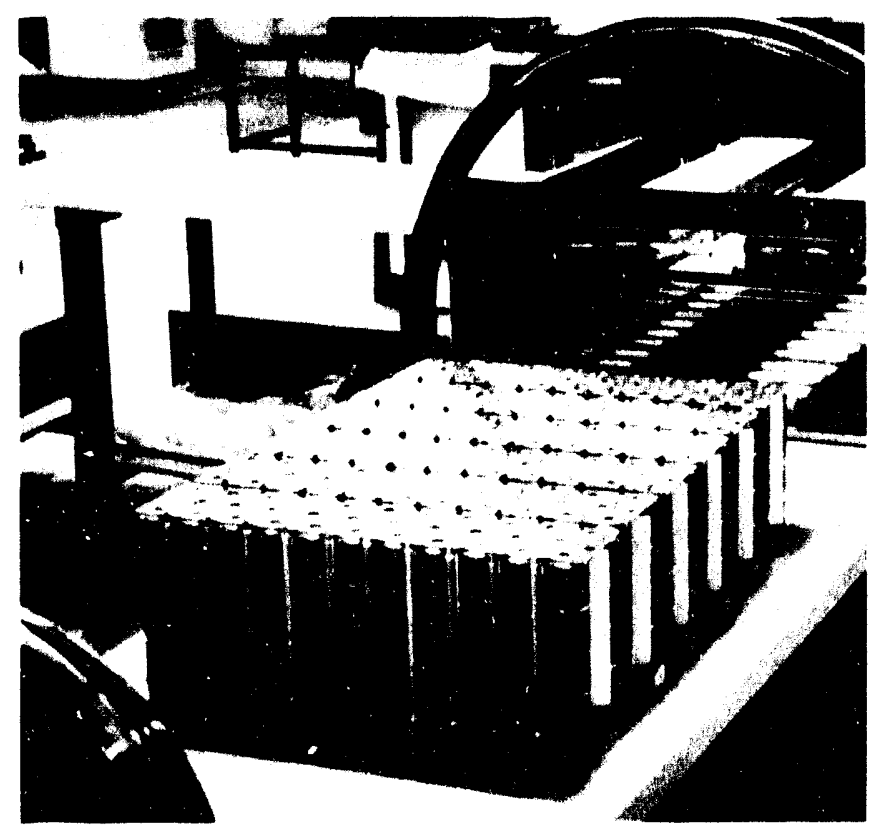

New sodium-sulfur batteries promise increased reliability for electric vehicle performance.

Engine Systems. Battery characteristics are matched to vehicle requirements. Energy density for batteries is low relative to other fuels, and affects driving range. Adding more battery modules increases weight, and decreases efficiency. Typical light-duty vehicles today might have a range of $\mathbf{4 5}$ to $\mathbf{5 0}$ miles. The number of battery modules needed to meet the voltage requirements of the vehicle must also be determined. The number of modules affects battery storage space and total weight, which can be a limitation. While many of today's battery configurations provide 120 volts, some newer voltage design requirements are in the 340 - to 360 -volt range. Higher voltages allow higher motor revolutions per minute, which in turn allows for lighter motors. However, battery energy densities decrease slightly with increasing voltages.

\footnotetext{
${ }^{223}$ Christopher S. Weaver, "Natural Gas Vehicles-A Review of the State of the Art," Society of Automotive Engineers (SAE), Paper No. 892133 (Warrendale, PA, 1989), pp. 39-40.

${ }^{21}$ U.S. Department of Energy, Assessments of Costs and Benefits of Flexible and Alternative Fut: Use in the U.S. Transportation Sector. Technical Report Four: Vehicle and Fuel Distribution Requirements, p. 38.
} 

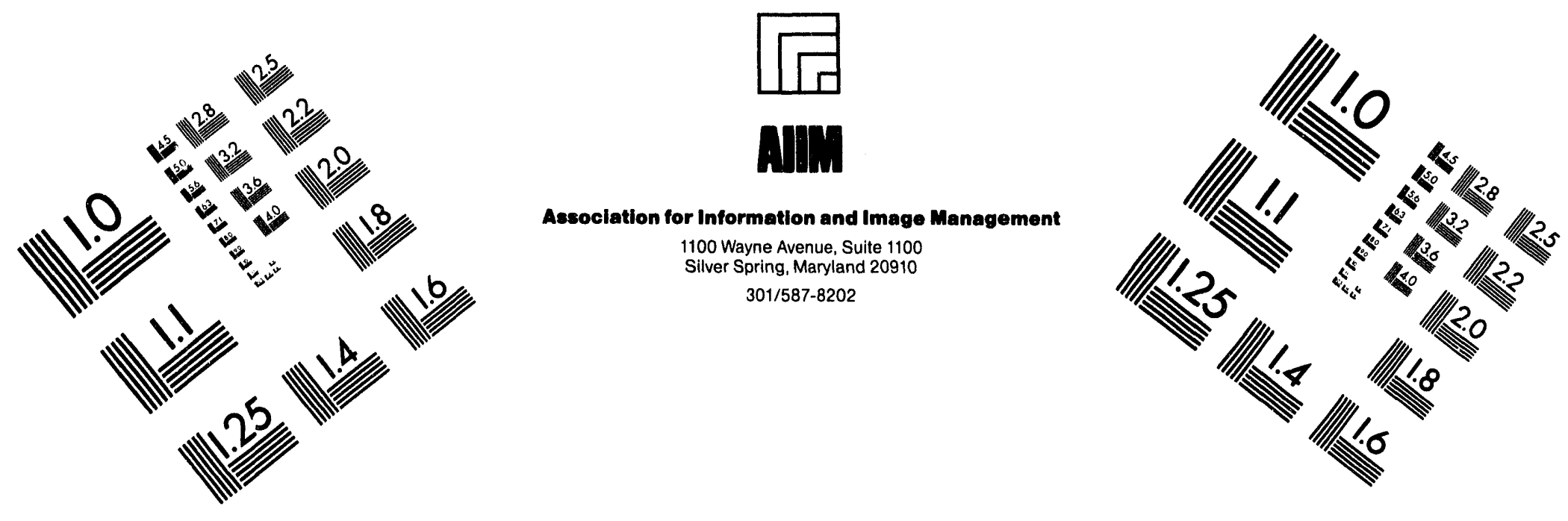

\section{Centimeter}

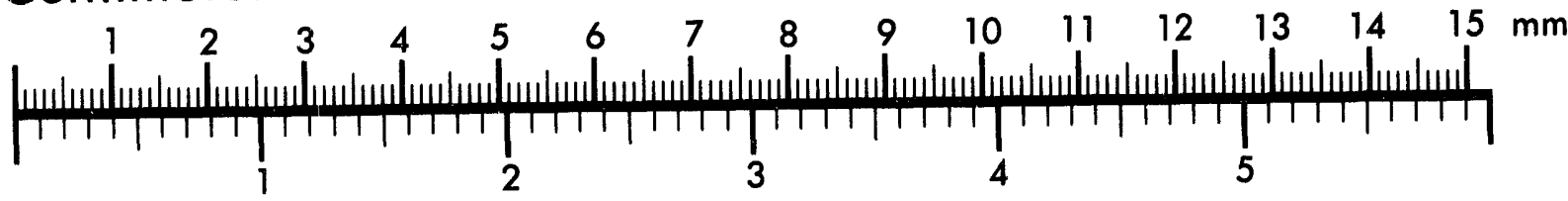
Inches
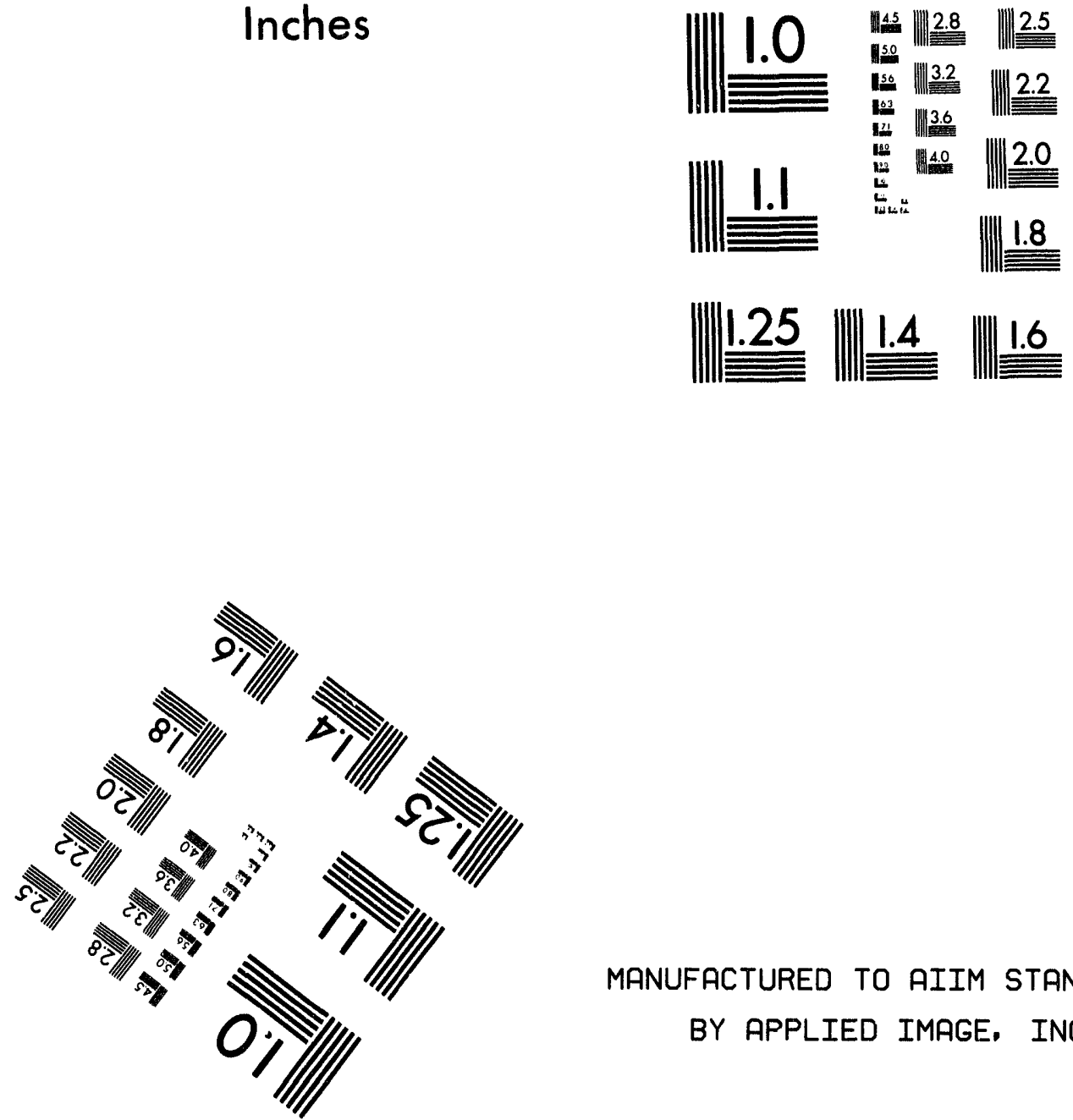

MANUFACTURED TO AIIM STANDARDS

BY APPLIED IMAGE, INC.

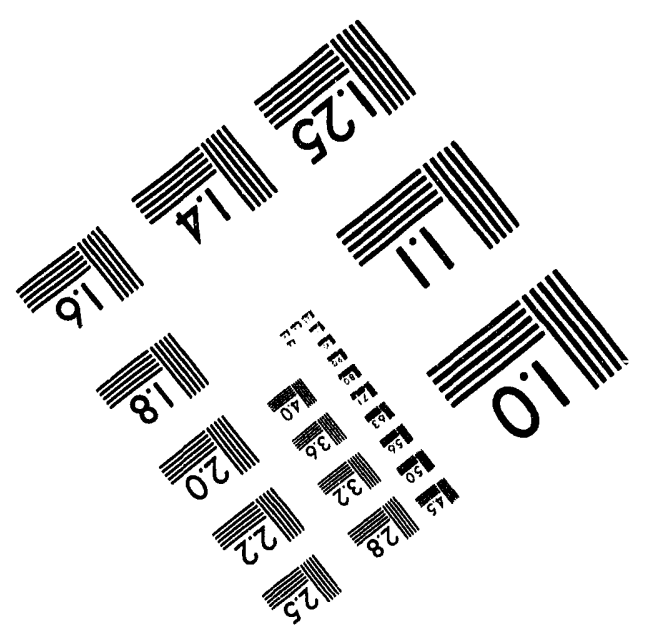



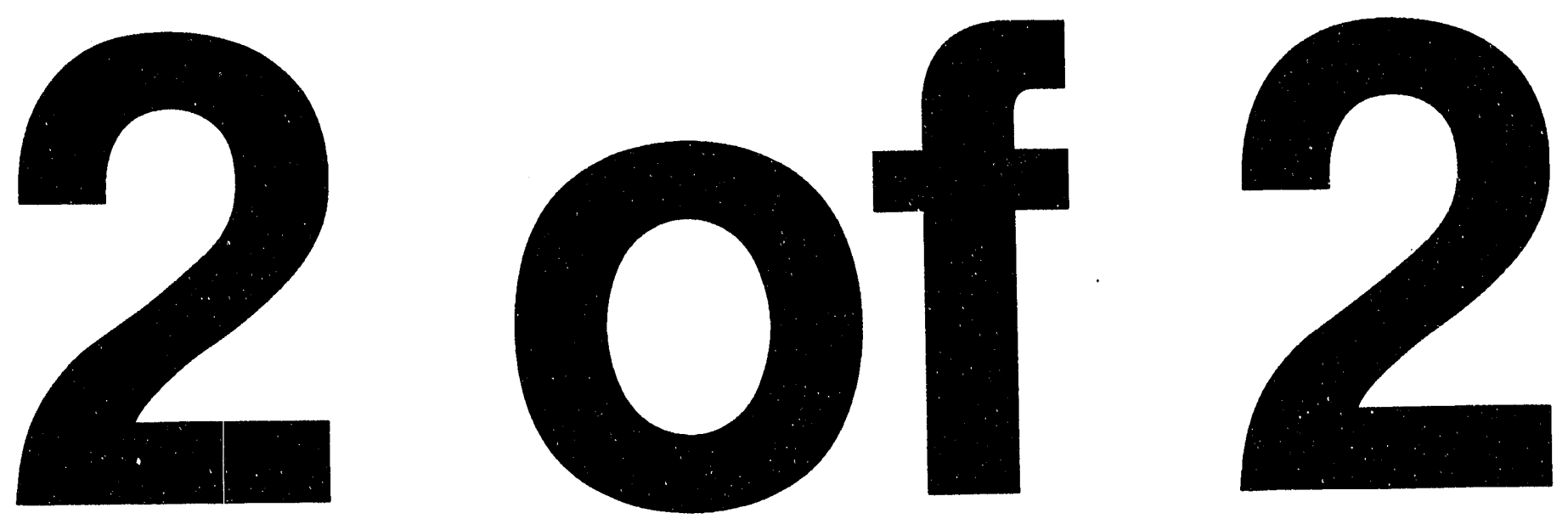
Peak power output, which affects the acceleration times for vehicles, is also important. Peak power density must be maintained as the battery discharges, or acceleration performance will also degrade. ${ }^{225}$ Today's electric cars take about 16.4 seconds to reach 50 miles per hour. However, electric cars are expected to reach 60 miles per hour in 10 seconds within a few years. ${ }^{26} \mathrm{~A}$ battery can be optimized for maximum energy or maximum power, but not both. Specific power (watt per kilogram) declines as specific energy (watthour per kilogram) increases. ${ }^{227}$

The motor, which includes electrical connections and cables, converts electrical energy to mechanical energy to propel the vehicle. Controllers regulate electric flow from the battery pack to the motor. The converter transforms 6-volt direct current to 12-volt in order to operate auxiliary equipment, such as windshield wipers and headlights. Although direct current drives have been used traditionally, alternate current power trains that reduce weight and cost of propulsion motors are being designed and tested.

Battery support systems include an external battery charger with output cable and charging connectors as well as a watering can for battery maintenance. After initially charging the battery, the charger sends periodic refresher charges to the battery to maintain a fully charged state. An on-board charger extends the vehicle range by allowing for batiery recharging at a site other than a regular recharging station. While many existing pure electric vehicles do not have on-board chargers, recent powertrain packages being offered ${ }^{228}$ include battery charger, fuel gauge, and direct-current converter.

The watering can, in a separate unit from the vehicle, is used for battery watering. Batteries are generally washed every 3 weeks or 500 miles, varying with climate. A central automatic watering system, available from manufacturers of electric vehicles, connects to two manifolds located in the front of the vehicle.
Although electric vehicles are cleaner ${ }^{229}$ and less noisy, vehicles propelled by gasoline offer a substantially longer driving range and a more rapid refueling time. Regenerative braking is an energy-saving technique. During deceleration, battery charging is performed through regenerative braking, in which the motor is operated as a generator. Recharging the battery in this manner yields a longer driving range.

An electric car today might have a range of about 45 miles with a lead-acid battery, 90 miles with a nickeliron battery, and 205 miles with a sodium-sulfur battery. Range decreases as battery life increases. ${ }^{230}$

\section{Hydrogen Vehicles}

Hydrogen vehicles have either combustion engines that burn hydrogen directly, or they are electric vehicles using fuel cells requiring hydrogen. As a transition to a full hydrogen vehicle, "Hythane" fueled vehicles are also being studied. Hythane is a mixture of 15 percent hydrogen and 85 percent natural gas by volume ( 5 percent hydrogen by energy content). ${ }^{231}$

Fuel Storage. As in the case of natural gas, on-board storage of hydrogen is a key component to success. The three types of storage systems being pursued are compressed hydrogen, liquid hydrogen, and the chemical bonding between hydrogen and a storage material, for example, metal hydrides. Hydrogen storage is constrained by container weight and volume.

For example, a small hydrogen-fueled sports coupe used in a recent demonstration contained an array of 2foot-long metal hydride cells that took up the entire trunk space and weighed 660 pounds (compared with a gasoline tank that might weigh 110 pounds when filled). The weight of the fuel tanks was associated with the vehicle's slow acceleration time of 13 seconds to reach 60 miles per hour. The low energy density of the fuel with the added weight of fuel storage kept the range of this demonstration vehicle down to 96 miles.

\footnotetext{
${ }^{225}$ A.F. Burke, "Battery Availability for Near-Term (1998) Electric Vehicles," Society for Automotive Engineers (SAE) Paper No. 911914 (Warrendale, PA, 1991), pp. 22-23.

${ }^{226}$ U.S. Department of Energy, Assessments of Costs and Benefits of Flexible and Alternative Fuel Use in the U.S. Transportation Sector. Technical Report Four: Vehicle and Fuel Distribution Requirements, p. 42.

${ }^{227}$ Glenn W. Merry, "Zinc-Air Batteries for Electric Vehicles," Society for Automotive Engineers (SAE) Paper No. 911912 (Warrendale, PA, 1991), p. 11.

${ }^{228}$ U.S. Department of Energy, Assessments of Costs and Benefits of Flexible and Alternative Fuel Use in the U.S. Transportation Sector. Technical Report Four: Vehicle and Fuel Distribution Requirements, p. 40.

${ }^{229}$ While electric vehicles are subject to some environmental penalty, several factors make electricity attractive as a vehicle fuel. Pollution is more easily controlled at a central electric generating source than at numerous mobile sources (vehicles). Power plants are often sited away from urban centers, removing the source of pollution from critical locations.

${ }^{230}$ U.S. Department of Energy, Assessments of Costs and Benefits of Flexible and Alternative Fuel Use in the U.S. Transportation Sector. Technical Report Four: Vehicle and Fuel Distribution Requirements, p. 42.

${ }^{231}$ The Clean Fuels Report, Vol. 4, No. 4 (Niwot, CO: J.E. Sinor Consultants, Inc., September 1992), p. 104.
} 
Engine Systems. Hydrogen, like the other alternative fuels, is best suited for spark-ignition engines, although there are some hydrogen- and dual-fueled modified compression-ignition engines. ${ }^{232}$

The high flame speed of hydrogen allows for more complete combustion and the potential to operate at leaner levels than fuels with lower flame speeds. The small amount of energy needed to ignite hydrogen fuel/air mixtures in conjunction with the wide flammability limits permits wide flexibility in operating the engine by varying the hydrogen/air ratio to adjust engine power and speed.

The small amount of energy required to ignite the mixture, however, has drawbacks. The fuel can be ignited inadvertently by such events as hot spots in the combustion chamber, by burning gases from the previous cycle for very lean operations, by lower flame speeds, and by hot particles from the engine oil. The subsequent flame causes backfiring or pre-ignition inside the combustion chamber. Methods to prevent pre-ignition and backfiring such as direct injection of hydrogen into the combustion chamber, ${ }^{233}$ are being pursued.

Overall, hydrogen-fueled engines have the potential to be more thermally efficient than gasoline-fueled engines. Thermal efficiency gains through compressionratio increases are more limited for hydrogen than one might expect from the high octane rating and high flame speeds. The pre-ignition problems just described hinder compression ratio increases. However, as preignition solutions are implemented, higher compression ratios can be obtained than in gasoline engines. High flame speed tends to reduce the burning time of the charge in the cylinder, therefore reducing heat loss and increasing thermal efficiency.

The low energy density of hydrogen requires a higher percentage of fuel to air at stoichiometric conditions than with gasoline. A stoichiometric mixture of gasoline contains about 1.7 percent per volume of gasoline, while hydrogen occupies 30 percent of the cylinder volume under the same conditions. Even though the heat of combustion on a mass basis is higher for hydrogen than for gasoline, hydrogen-fueled engines still experience a loss of engine power output compared with gasoline engines due to low heat of combustion (i.e., low energy density of the fuel). As in the case of pre-ignition, steps can be taken to improve the power output, such as direct injection of hydrogen into the combustion chamber to produce a "supercharging" effect that improves efficiency. ${ }^{234}$

Hydrogen contains no hydrocarbons, but $\mathrm{NO}_{x}$ emissions are of concern. These emissions, which depend on fuel/air mixtures and temperature, can be higher for hydrogen-fueled engines than for gasoline-fueled engines. $\mathrm{NO}_{\mathrm{x}}$ emissions are low for lean and rich hydrogen mixtures, peaking in between. They can be lowered further by reducing the oxygen concentration in the combustion chamber, by reducing the combustion chamber temperature, or by shortening combustion time at high temperatures. These steps can be accomplished by exhaust gas recirculation, water injection into the cylinder, retarding spark timing, or by using an exhaust catalyst. ${ }^{235}$

\footnotetext{
${ }^{232} \mathrm{C}$. Borusbay and T. Nejat Veziroglu, "Hydrogen as a Fuel for Spark Ignition Engines," Alternative Energy Sources VIII, Volume 2, Research and Development (New York: Hemisphere Publishing Corporation, 1989), p. 558.

${ }^{233} \mathrm{C}$. Borusbay and T. Nejat Veziroglu, "Hydrogen as a Fuel for Spark Ignition Engines," pp. 562, 566.

${ }^{234} \mathrm{C}$. Borusbay and T. Nejat Veziroglu, "Hydrogen as a Fuel for Spark Ignition Engines," p. 570.

${ }^{235} \mathrm{C}$. Borusbay and T. Nejat Veziroglu, "Hydrogen as a Fuel for Spark Ignition Engines," p. 570.
} 


\section{Emerging Fuel Resources}

\section{Introduction}

In addition to the fuels discussed in the prior chapters, biomass fuels other than alcohols and coal-derived fuels are designated as potential alternative fuels or replacement fuels. Biomass can be used to produce fuels through two means: fermentation and hydrolysis to produce ethanol, as already discussed in Chapter 6; and direct extraction of oils that can be used as fuels. This chapter discusses biodiesel from oil extraction and provides a brief overview of how coal can be used to produce different fuels. Although these fuels are being tested today, neither biodiesel nor transportation fuels derived from coal are produced in large quantities in the United States. As these fuels begin commercial operation, they likely will be used initially in conjunction with traditional fuels.

\section{Biodiesel from Vegetable Oils}

Biodiesel is a product derived from vegetable oils that can be mixed with diesel fuel or can be used as a replacement for diesel fuel. Biodiesel is produced in an inexpensive transesterification process by reacting vegetable oil with methanol or ethanol in the presence of a liquid basic catalyst. The yield of biodiesel (esters) is about 96 percent, with glycerin produced as a byproduct.

Biodiesel can be produced from a number of vegetable oil sources (Table 33). The most economical choice will depend on the oil yield per acre, product quality, byproduct values, geography, and government policies. Considerable interest has been shown in rapeseed oil $^{236}$ because of oil yields and the value of byproducts (livestock feed) from the oil production. At current crude oil prices, however, none of the vegetable oils are economic sources without substantial government subsidies.

The physical properties of biodiesel produced from rapeseed oil (rape methyl ester) are compared with the unconverted rapeseed oil and conventional diesel
Table 33. Estimated World Vegetable OII Production and Yields, 1990

\begin{tabular}{|c|c|c|}
\hline Vegetable Oil Source & $\begin{array}{l}\text { Production } \\
\text { (Million } \\
\text { Motric Tons) }\end{array}$ & $\begin{array}{l}\text { Oll Yield } \\
\text { (Metrle Tons } \\
\text { per Hectare } \\
\text { per Year) }\end{array}$ \\
\hline $\begin{array}{l}\text { Chinese tallow tree } \ldots \\
\text { Coconut } \ldots \ldots \ldots \ldots \\
\text { Cotton } \ldots \ldots \ldots \ldots \\
\text { Palm } \ldots \ldots \ldots \\
\text { Peanuts } \ldots \ldots \ldots \\
\text { Rapeseed } \ldots \ldots \ldots \ldots \\
\text { Sesame } \ldots \ldots \ldots \ldots \\
\text { Soybean } \ldots \ldots \ldots \ldots \\
\text { Sunflower } \ldots \ldots \ldots \ldots\end{array}$ & $\begin{array}{c}\text { (research status) } \\
3.3 \\
3.8 \\
7.0 \\
4.0 \\
5.7 \\
0.7 \\
17.0 \\
8.0\end{array}$ & $\begin{array}{l}4.0-6.0 \\
3.0-4.0 \\
0.3-0.5 \\
5.0-8.0 \\
1.0-2.5 \\
1.0-2.0 \\
0.2 \\
0.2-0.6 \\
1.0-1.5\end{array}$ \\
\hline
\end{tabular}

Source: Daniel Lumbroso, Jean-Alain Chodorge, and Gary Stephens (IFP Enterprise, Inc., Houston, TX), "The Case for Bio-Diesel Fuel, ${ }^{n}$ paper presented at The World Conference on Refinery Processing and Reformulated Gasoline, March 23-25, 1993, San Antonio, TX, p. 4.

(Table 34). Biodiesel has physical properties very similar to conventional diesel. Emission properties, however, are better for biodiesel than for conventional diesel. Biodiesel has no aromatic content and only trace amounts of sulfur. In vehicle tests, it has lower emissions of carbon monoxide, soot, and polycyclic aromatic hydrocarbons than conventional diesel. $\mathrm{NO}_{\mathrm{x}}$ emissions are higher for biodiesel than for conventional diesel when using the EPA test cycle. However, one study illustrated that with adjustments in the injection engine timing, $\mathrm{NO}_{\mathrm{x}}$ can be reduced without jeopardizing the other low emission levels. ${ }^{237}$

\section{Coal-Derived Transportation Fuels}

Gasoline, diesel, and various oxygenated transportation fuels have been produced from coal, using a variety of alternative processes. These processes fall into two categories, direct and indirect liquefaction. Indirect liquefaction processes all have a common first step: production of synthesis gas (carbon monoxide and hydrogen gas) through the gasification of coal. The

\footnotetext{
236"Feedstocks and Resources," Clean Fuels Report, Vol. 5, No. 1 (Niwot, CO: J.E. Sinor Consultants, Inc, February 1992$),$ p. 144.

${ }^{237}$ Windel Goetz, Evaluation of Methyl Soyate/Blend in a DDC 6V-92TA Engine: Optimization of NO Emissions, ORTECH Report 93-E14-36 (Mississauga, Ontario, July 20, 1993).
} 
Table 34. Product Characteriatics

\begin{tabular}{|c|c|c|c|}
\hline Characteriatic & Conventional Diesel & Blodiesel & Rapeseed OII \\
\hline Specific Gravity . & 0.84 & 0.88 & 0.92 \\
\hline Viscosity $22^{\circ} \mathrm{C}$ (centistokes) & 5 & 7.5 & 78 \\
\hline Cetane Index $\ldots \ldots \ldots \ldots \ldots \ldots \ldots$ & 50 & 49 & 32 \\
\hline Cold Filter Plugging Point $\left({ }^{\circ} \mathrm{C}\right) \ldots \ldots \ldots$ & -15 & -12 & * \\
\hline Net Heating Value (kilojoules per liter) & 35,400 & 33,300 & 34,300 \\
\hline
\end{tabular}

"Viscosity is too high even at $+20^{\circ} \mathrm{C}$ to conduct the standard test.

Notes: Specific gravity is the ratio of the weight of a given volume of material to the weight of an equal volume of some standard substance. In the case of oil, the standard reference material is distilled water, and the temperature of both the oil and water is 60 degrees Fahrenheit. Viscosity is the measure of the internal friction or resistance to flow of a fluid. A centistoke (one-hundredth of a stoke, which is measured in square centimeters per second) is a measure of kinematic viscosity. Kinematic viscosity is the ratio of viscosity of a liquid to its specific gravity at the temperature at which the viscosity is measured. The cetane index is an approximation of cetane number based on an empirical relationship with API gravity and volatility parameters, such as the mid boiling point. Cold filter plugging point is a measure of the ability of a diesel fuel to operate satisfactorily under cold weather conditions. The value is a measure of the lowest temperature at which wax separating out of a sample can stop or seriously reduce the flow of fuel through a standard filter under standard test conditions.

Source: Daniel Lumbroso, Jean-Alain Chodorge, and Gary Stephens (IFP Enterprises, Inc., Houston, TX), "The Case for Bio-Diesel Fuel," Presentation at World Conference on Refinery Processing and Reformulated Gasoline, San Antonio, TX, March 23-25, 1993.

synthesis gas can then be converted into a variety of fuels. As covered in earlier discussions, the synthesis gas can be converted to methanol. There are also processes being developed to produce higher alcohols and ethers such as MTBE. ${ }^{238}$

There are also two methods for producing gasoline and diesel from the synthesis gas: (1) In the Fischer-Tropsch process, which was first discovered in Germany in the 1920s, synthesis gas produced from coal by means of gasification is fed to a reactor. In the reactor, the synthesis gas comes into contact with an iron catalyst at high temperature and pressure. The process produces a wide range of hydrocarbons of different chain lengths as well as a number of oxygenates such as alcohols and ketones. Most of the hydrocarbons fall into the gasoline and diesel boiling range and can vary from about 80 percent gasoline to approximately 70 percent distillate fuel. The Fischer-Tropsch process has been commercialized by Sasol Ltd. in South Africa. Three units have been built there, using two different process designs. Fischer-Tropsch continues to be developed using new catalysts. (2) The other way to derive gasoline and diesel is to first convert the gas to methanol, and then into gasoline and diesel. . $39,240^{2}$
Coal can also be converted to gasoline and diesel by direct liquefaction. Compared with crude oil, coal has less hydrogen (5 percent vs. 12 to 14 percent) and a higher average molecular weight. Direct liquefaction involves adding hydrogen and cracking the coal molecules to form a synthetic crude oil, which then can be converted to gasoline, diesel and other products using conventional refinery processes. The direct coal liquefaction process has evolved over the past 80 years.

Since the 1970s, an integrated two-stage liquefaction process has been developed. The process effects a reduction in the pressure required over the single-stage process and makes more efficient use of hydrogen. It uses recycled heavier coal liquids as a solvent to dissolve the coal in the first stage.

At current crude and gas prices, neither indirect nor direct liquefaction is economic. Research efforts continue to focus on cost reduction to provide a commercialization process that will enter the market when crude prices climb as oil and gas resources become further depleted.

\footnotetext{
${ }^{238}$ Kamil Klier et al., "High Octane Ethers from Synthesis Gas-Derived Alcohols," Liquefaction Contractors; Review Meeting, Pittsburgh Energy T'echnology Center, Contract DE-AC22-90PC90044 (September 22-24, Pittsburgh, PA, 1992), p. 291.

${ }^{239}$ S.A. Tabak, A.A. Avidan, and F.J. Krambeck (Mobil), "Production of Synthetic Gasoline and Diesel Fuel from Non Petroleum Resources," Preprints of papers presented at meeting of American Chemical Society Division of Fuel Chemistry, New York City, April 13-18, 1986, Vol. 31, No. 2, p. 293.

${ }^{240}$ B.K. Warren et al. (Union Carbide), Direct Conversion of Methane to C2's and Liquid Fuels, Final Technical Progress Report for the Period October 1, 1987 to December 31, 1989, DOE/PC/79817-8, April 15, 1990.
} 


\section{Greenhouse Gas and Harmful Emission Formation}

\section{Background}

As mentioned in Chapter 4, the so-called "greenhouse gases" are thought by many to contribute to the observed global warming trend. This chapter provides background on the Earth's climatology and then describes greenhouse gases and how they are thought to contribute to global warming. The chapter concludes with some information on harmful greenhouse gasrelated emissions from transportation fuel use.

The complex interactions of land, sea, atmosphere, and man make predicting climatological change extremely difficult. Despite an ever-growing world population and food system, other climatic factors (some unknown) overwhelmed anthropogenic impacts and caused a 650year global cooling period beginning in 1200 A.D. After the so-called "Little Ice Age" ended around 1850 A.D., harvests stabilized and subsistence yields increased into stable cash crops. This period was only the most recent of several mini-Ice Ages since the Great Ice Age, which ended about 20,000 B.C. Thus, the Earth's current temperate climate appears to be an interlude between major cyclical events. Global temperatures and sea levels have been increasing steadily since around 1850, partially because the Earth is coming out of an ice age, partially in response to human emissions. This trend has accelerated over the past 40 years, with the sea level having risen almost 1.75 centimeters ( 0.7 inch) per decade. A long-term "greenhouse effect" (if it exists) $)^{241}$ could lead to anything from a vastly smaller water world with dramatically higher sea levels to a cooler, icier world. ${ }^{242}$

\section{Climatology}

The water world in which we live is constantly changing in response to a large number of sometimesoffsetting complex factors, both natural and manmade. Extremely diverse, quasi-stable biospheres have existed under the range of environments in the 2 billion years the Earth has supported some form of life. When changes occur slowly, the biosphere changes somewhat gently and species usually adapt. But sometimes the rate of change in the environment has been so great that virtually all-or at least many-species' populations have changed or disappeared. Ocean temperatures, sea levels, radiation from the sun, the mix of atmospheric gases, and cultural exploitation of natural resources are five key variables that contribute to climate change, both in periodic and one-time fashion. Even slow, small changes, if they persist, could begin a cascade of relocating major coastal cities, shrinking and/or relocation of tillable land, and a loss of species. For example, if the warming trend of the past 40 years-whatever the cause-were to continue, ocean levels would rise by 2 meters (6 feet) during the next 1,200 years. This would flood most coastal estuaries, ecosystems for breeding of many migratory birds, far faster than new ones could appear. Coastal populations could also be affected.

Adding to these concerns is the uncertainty surrounding efforts to predict global climate change. Even though a given model of world climate may forecast a general warming trend as a result of increased greenhouse gas concentrations, the impacts are hardly uniform across the globe. Some regions are predicted to get more precipitation; others less. Certain latitudes might even become cooler as greenhouse gases rise. Further adding to the uncertainty is that this unevenness is not uniform across global climate models.

While greenhouse gases may adversely affect the climate in one way, the Earth's capacity to support life depends on the moderating influences of these gases to envelop the planet, warm its surface, and protect it from harmful radiation. ${ }^{243}$ Some greenhouse gas molecules in the atmosphere absorb, reflect, mitigate, and radiate energy more than others, doing so in a way that makes human life possible.

\footnotetext{
${ }^{241}$ The theory of global warming due to higher concentrations of greenhouse gases is known as the "greenhouse effect."

${ }^{242}$ I.D. Campbell and J.H. McAndrews, Nature, November 25, 1993.

${ }^{243}$ Energy Information Administration, Emissions of Greenhouse Gases in the United States 1985-1990, DOE/EIA-0573 (Washington, DC, September 1993), p. xix.
} 


\section{Greenhouse Gases}

\section{Definition and Behavior}

Greenhouse gases (GHGs) include all gases which exist in the atmosphere and act, either directly or indirectly, to cause global temperatures to change. These gases retain heat around the Earth in much the same way that humid air within a greenhouse retains heat; hence the terminology. Water in a gaseous state is the dominant greenhouse gas. It is largest in terms of mass (about 1 percent of the atmosphere, with carbon dioxide second at about 0.04 percent) and has one of the broadest ranges of all atmospheric gases regarding absorption of incoming solar radiation and outgoing surface energy.

The effect of GHGs is not uniform throughout the atmosphere. The atmosphere changes both its density and its relative composition with altitude. GHGs typically prevent heat from leaving the lower atmosphere (troposphere), warming the air. However, some GHGs are sufficiently light that they go up through the tropopause, causing stratospheric warming.

The warming capability of GHGs varies widely. On a molecular basis, some GHGs have a disproportionate warming effect. For example, in terms of heat absorption potential over its lifetime in the atmosphere, one molecule of methane can have about 20 times the effect on the climate of one molecule of carbon dioxide. ${ }^{244}$ When fuel is burned, the energy of combustion will produce heat, which is either stored in the exhaust or radiated into the atmosphere.

Different GHGs respond in quite disparate manners to solar radiation. Some, such as ozone, react directly to incoming solar radiation entering the atmosphere. The energy is absorbed and reradiated in a moderated form to warm the atmosphere. In the stratosphere, ozone acts as a protective GHG. An increase in stratospheric ozone concentration may decrease the radiation reaching the surface. Stratospheric ozone depletion allows more radiation to reach the troposphere and the Earth's surface. Radiation striking the surface is subsequently radiated back into the atmosphere, where it may be absorbed by various GHGs. Atmospheric concentrations of selected GHGs in the history of the world are shown in Table 35.

Most GHGs, such as carbon dioxide, absorb energy radiated by other GHGs or the surface. In this case, an increase in concentration of a GHG will decrease the radiation leaving the Earth, another contribution to global warming.

Some GHGs are also determinants in regional air quality, having been identified both in terms of chemical species which cause the most problems and in terms of where they occur. One example is ozone, which harms human respiration. ${ }^{245}$ Ozone formed in the troposphere, does not appear to migrate into the stratosphere. Thus, even though tropospheric ozone comprises only about 10 percent of total atmospheric ozone, it is a major health concern. The warmth and oxidizing reactions of tropospheric ozone do not remain at the point source but spread out across a downwind region, again adding warmth to the Earth and affecting peoples' lungs.

Certain GHGs are precursors in the formation of tropospheric ozone. The transportation sector is one of the prime creators of these precursors. Localized concentrations of various GHGs create cauldrons for atmospheric chemistry, islands of pollution which have a severe impact on air quality and health of people, both region-

Table 35. Atmospheric Concentrations of Selected Greenhouse Gases, 1990

\begin{tabular}{c|c|c|c}
\hline Category & Carbon Dloxide & Methane & Nitrous Oxide \\
\cline { 2 - 4 } & \multicolumn{3}{|c}{ (parte per million) } \\
\hline Preindustrial Atmospheric Concentration $\ldots \ldots \ldots \ldots \ldots \ldots$ & 280 & 0.80 & 0.29 \\
Current Atmospheric Concentration $\ldots \ldots \ldots \ldots \ldots \ldots \ldots$ & 353 & 1.72 & 0.31 \\
Rate of Change (ppm or ppt per year) $\ldots \ldots \ldots \ldots \ldots \ldots$ & 1.8 & 0.02 & 0.8 \\
\hline
\end{tabular}

Source: Energy Information Administration, Emissions of Greenhouse Gases in the United States 1985-1990, DOE/EIA-0573 (Washington, DC, September 1993), p. 1.

\footnotetext{
${ }^{24}$ Energy Information Administration, Emissions of Greenhouse Gases in the United States 1985-1990, p. 1.

${ }^{245}$ Carbon monoxide is another greenhouse gas that affects regional air quality.
} 
ally and downwind. The cumulative affect of local GHG emissions is to modify global conditions.

While recent losses of stratospheric ozone have been well documented, the precise effect of ozone losses on stratospheric temperatures remains uncertain at this time. ${ }^{246}$ However, ozone's oxidizing behavior, indirect global warming effects, and the direct warming effect of tropospheric ozone are significant. Upper tropospheric ozone concentrations have the most pronounced warming effects. Unfortunately, it is not currently possible to quantify global warming due to tropospheric ozone ${ }^{247}$ or any other GHG.

\section{Sources of Greenhouse Gases}

Greenhouse gases come from both natural and manmade sources. ${ }^{248}$ In the United States, mobile sources are estimated to emit about 30 percent of the GHGs. Most of these arise from the combustion of motor fuels. GHGs are emitted during the entire production, distribution, and end use processes that a fuel undergoes. These emissions might be considered relative to the annualized cradle-to-grave life cycle of each energy flow. Much of the remaining 70 percent come from fossil-fueled electric power plants. The entire fuel cycle has six basic components, discussed earlier (Chapter 4). Each has a unique set of emissions (see Appendix F).

\section{Determining the Background Level of a Greenhouse Gas}

While background mixes of gases have varied considerably over time, good records exist only for the recent past. Background levels of GHGs have varied widely over both short-term and long-term periods. For example, volcanic activity produces sharp changes in the relative composition of the atmosphere. Also, the mix seems to have shifted during periods of global cooling. Early eons might have had either much more oxygen or much less than we enjoy right now.

Solar radiation has a major impact on climate, both directly and indirectly. As radiation from the sun penetrates the Earth's atmosphere, different gases absorb selected bands of energy from the wide spectrum of solar radiation. Virtually all the high-energy radiation is absorbed before it has a chance to strike the

When Mt. Pinatubo erupted in June 1991, it spewed 15 to 20 million tons of sulfur dioxide gas as high as 11 miles $(19 \mathrm{~km})$, where the gas converted to tiny droplets of sulfuric acid. Immediately after the eruption, these droplets raised the stratosphere's temperature sharply by absorbing thermal radiation rising from the Earth's surface and lower atmosphere. At the same time, the droplets cooled the planet's troposphere and surface by reflecting sunlight, functioning as a giant semi-translucent umbrella covering the planet.

When the sulfate particles began dropping out of the stratosphere during the year after the eruption, stratospheric temperatures also started to decline. But instead of returning to normal, the stratosphere cooled far below its average temperature, reaching record lows by the end of 1993. Scientists saw a similar effect after the eruption of Mexico's El Chichon in 1982. In fact, stratospheric temperatures remained below average for 7 years following that eruption; they only recovered when the Mt. Pinatubo blast warmed the stratosphere.

Ozone depletion may help explain the continued cooling trend in this region of the atmosphere. Ozone molecules in the stratosphere normally heat this region by absorbing solar energy. When ozone concentrations drop, as they did dramatically after the Mt. Pinatubo eruption, temperatures in the stratosphere also decline. Although chlorofluorocarbons and other anthropogenic pollutants also cause long-term stratosphere ozone depletion, volcanic sulfuric acid makes a major contribution as well.

Although stratospheric temperatures continued to decline late in 1993, Mt. Pinatubo's cooling influence on the Earth's surface appears to be waning. Satellite and balloon data indicate that tropospheric temperatures increased slightly in 1993, but have not yet recovered to pre-eruption levels. The Mt. Pinatubo eruption interrupted the dramatic rise in the Earth's surface temperatures during the 1980 s which had prompted concern about global warming. Now that its cooling effect on the troposphere appears to be dying out, researchers will be watching closely to see if the marked increase in global temperatures continues in coming years.

\footnotetext{
${ }^{246}$ Intergovernmental Panel on Climate Change, Climate Change 19э2, eds. J.T. Houghton, B.A. Callander, and S.K. Varney (New York: Cambridge University Press, 1992), pp. 58-59.

${ }^{247}$ Intergovernmental Panel on Climate Change, Climate Change 1992, eds. J.T. Houghton, B.A. Callander, and S.K. Varney (New York: Cambridge University Press, 1992), pp. 58-60. Office of Technology Assessment, Analysis of the U.S. Global Change Research Program (USGCRP) (Washington, DC, December 1993).

${ }^{248}$ For a more complete discussion, see Energy Information Administration, Emissions of Greenhouse Gases in the United States $1985-1990$.
} 
Earth's surface, with a small amount of harmful ultraviolet penetrating. ${ }^{249}$ Some radiation, mostly in the visible and infrared ranges of the spectrum, penetrates to the surface; some is reflected by the atmosphere. Some reaches the surface to be converted by plants into food, and some warms the land and oceans. Some is later re-radiated with a different energy spectrum, only to be trapped in the atmosphere or propagated into space.

At one time, anthropogenic heat was assumed to be insignificant in the grand climatological picture. If true, a "dilute and disperse" treatment would suffice. This assumption is now being evaluated for validity.

\section{Greenhouse Gas Measurements}

Measurements of GHG emissions are not an exact science. Estimating emissions over the entire fuel cycle, including indirect emissions, ${ }^{250}$ is an extremely difficult task. Converting these measured emissions to estimates of global warming potential adds an additional level of complexity. Among the major issues in estimating GHG emissions over the entire fuel cycle for any transportation fuel are the following:

- Definition of the fuel cycle.

- Averaging across vehicles-Very large differences exist in measured emissions from similar vehicles using the same fuels. These differences exist even with accurate measurements.

- Measurement difficulties-Many of the accepted components of the fuel cycle are difficult to measure, e.g., on-road combustion and noncombustion emissions, emissions from vehicle manufacture (including secondary effects). These measurement difficulties exist regardless of how a vehicle or group of vehicles is defined.

- Incorporating off-specification emissions-Considerable evidence shows that emissions from poorly maintained vehicles, venting during refueling, leakage, and similar off-specification factors are extremely large. These emissions may exceed design emissions and may significantly change the relative greenhouse impact of a particular ATF/AFV combination.

- Including secondary and tertiary income and substitution effects from switching fuels or fuel supply
sources-It is difficult to draw a line defining what is included in a "fuel cycle." For example, substitution of methanol for petroleum increases emissions from ocean shipping (since all marginal methanol production will be imported and will require more shipping capacity than petroleum requires). This increase in shipping means an increase in petroleum usage (as bunker fuel in tankers) and an increase in demand for low-gravity petroleum products. If the increase is large enough, it may affect the price of other petroleum products, on the margin. These marginal changes may affect the relative economics of methanol and gasoline, and so on.

- Overall macroeconomic impacts-Changes in consumer preferences for vehicles (e.g., full-size vs. compact), driving patterns (e.g., carpooling), vehicle origin (e.g., U.S. vs. non-U.S., and the attendant emissions from manufacturing, shipping, etc.), fuel manufacturing processes and location (e.g., CNG from U.S. gas or Mideast gas shipped as LNG) can, within a very brief period of years, eliminate or reverse any expected impacts from the straightforward substitution of one fuel for another, everything else being equal.

\section{Greenhouse Guses and Air Pollution}

Some GHGs affect air quality and are well known as chemical species which cause substantial problems by impacting highly populated areas where they can affect peoples' health. Highway vehicles and other sources contribute GHGs to both surface level (tropospheric) and stratospheric pollution.

Air pollutants fall into two broad categories: substances unhealthy to living organisms and substances called either reactants or precursors. The latter react with other substances to form compounds in the troposphere which are unhealthy, contribute to stratospheric conditions which cause global warming, or both. Harmful chemical species and reactants are produced by both human activities and the normal biochemical processes and decaying of plants and animals.

Highway vehicles make up the largest polluting group in the transportation sector. In 1990, highway vehicles accounted for roughly 60 percent of the total of all sources of emissions of the major pollutants. ${ }^{251} \mathrm{CO}$, $\mathrm{NO}_{x}$, and VOCs are responsible for the most serious air

\footnotetext{
${ }^{249}$ Among the harmful effects of ultraviolet radiation is sunburn.

${ }^{250}$ Indirect sources might include chlorofluorocarbons used in manufacturing electronic components of the vehicle, and coal consumed in moving products to market.

${ }^{251}$ U.S. Environmental Protection Agency, Office of Air Quality Planning and Standards, National Air Pollutant Emission Estimates 19001991, EPA-454/R-92-013 (Washington, DC, October 1992), Tables 4, 5, 6, 7, and 8.
} 
quality problems from the standpoint of volumes genevated (Table 36); these are all GHGs. Particulate matter (an emission from diesel fuel but not a greenhouse gas), sulfates and nitrates cause the most severe damage. ${ }^{252}$

\section{Sulfatises}

Sulfur oxides (sulfates) are best known for their contribution to $\mathrm{pH}$ modification of clouds, better known as acid rain. However, they are also unhealthy because they irritate the mucous membranes in the eyes and lungs. In a recent finding, the sulfur oxides also appear to couriter the warming effect of other GHGs with their own ccoling effect.

Sulfates have been produced primarily by electric utility coal-fired plants. These emissions are being reduced through regulatory pressure and legislative mandates. Sulfur is also being reduced in diesel 'tel according to a regulatory timetable.

\section{Nitrates}

Nitrogen oxides (nitrates), hydroxyl ions, and VOCs are three anthropogenic groups of atmospheric reactants involved in smog generation. Individual chemical species feed the chain reaction process. The type and intensities of these reactions (some more favorable to ozone generation than others) vary according to their relative concentrations and amount of sunlight. Stagnant air masses and "urban canyons" can become cauldrons of atmospheric chemistry. For this reason, emission reduction strategies are tailored to address the specific problems of individual nonattainment areas, ${ }^{253}$ especially through the State Implementation Plans (SIPs).

Emission of $\mathrm{NO}_{\mathrm{x}}$ by highway vehicles is primarily a function of engine operating temperature and engine compression. However, other variables include the concentration of oxygen and humidity. VOCs, on the

Table 36. Emieslons of Primary Air Pollutants by Highway Vohicles In the United States, 1940-1990 and Projections to 2010

(Million Short Tons)

\begin{tabular}{|c|c|c|c|c|c|c|c|c|}
\hline \multirow[b]{2}{*}{ Pollutant } & \multicolumn{6}{|c|}{ Actual } & \multicolumn{2}{|c|}{ Projected } \\
\hline & 1940 & 1950 & 1960 & 1970 & 1980 & 1990 & 2000 & 2010 \\
\hline Carbon Monoxide (CO) . & 25.03 & 37.82 & 68.57 & 96.76 & 77.20 & 45.54 & 18.80 & 21.80 \\
\hline Nitrogen Oxides $\left(\mathrm{NO}_{x}\right) \ldots \ldots \ldots \ldots$ & 1.50 & 2.43 & 4.39 & 7.50 & 11.55 & 6.48 & 3.30 & 3.20 \\
\hline Panticulate Matter . . . . . . . . . . . & 0.22 & 0.33 & 0.66 & 1.00 & 1.16 & 1.41 & -- & -- \\
\hline Sulfur Oxides $\left(\mathbf{S O}_{x}\right) \ldots \ldots \ldots \ldots$ & 0.00 & 0.11 & 0.11 & 0.28 & 0.46 & 0.66 & .- & -- \\
\hline Volatile Organic Compounds (VOCs) & 4.76 & 7.16 & 10.80 & 12.68 & 7.56 & 4.70 & 1.80 & 1.80 \\
\hline \multicolumn{9}{|c|}{ Emlaslons from Highway Vehiclos as a Percent of Total Transportation Sector Emisalons } \\
\hline co.................. & 76 & 77 & 86 & 91 & 90 & 85 & N/A & N/A \\
\hline $\mathrm{NO}_{\mathrm{x}}$ & 60 & 61 & 75 & 80 & 84 & 75 & N/A & N/A \\
\hline VOCs $\ldots \ldots \ldots \ldots \ldots \ldots \ldots \ldots$ & 86 & 85 & 90 & 90 & 85 & 77 & N/A & N/A \\
\hline \multicolumn{9}{|c|}{ Emiselons from Highway Vehicles as a Percent of Emiselons from All Sources } \\
\hline$\ldots \ldots \ldots \ldots \ldots$ & 28 & 40 & 60 & 71 & 70 & 61 & 40 & 44 \\
\hline NO $_{x} \ldots \ldots \ldots \ldots \ldots \ldots \ldots \ldots$ & 20 & 23 & 30 & 36 & 44 & 30 & 19 & 16 \\
\hline $\operatorname{vocs} \ldots \ldots \ldots \ldots \ldots \ldots$ & 28 & 34 & 44 & 42 & 32 & 24 & 12 & 12 \\
\hline
\end{tabular}

Source: U.S. Environmental Protection Agency, Office of Air Quality Planning and Standards, National Air Pollutart Emission Estimates, 1900-1991, EPA-454/R-92-013 (Washington, DC, October 1992), Table 4-8.

\footnotetext{
${ }^{252}$ D.W. Dockery, New England Journal of Medicine, Dec. 9, 1993.

${ }^{255}$ For more detail, see U.S. Environmental Protection Agency, Office of Air Quality Planning and Standards, The Role of Ozone Precursors in Tropospheric Ozone Formation and Control, EPA-454/R-92-024 (Washington, DC, July 1993), Section 2.2.2.
} 
other hand, are gaseous hydrocarbons released into the atmosphere both by highway vehicles and by evaporation of fuel. The relative contributions of $\mathrm{NO}_{\mathrm{x}}$ and nonmethane VOC pollution from various sources are interesting to examine (Table 37).

Mandatory vehicle inspection and maintenance programs are being implemented as a strategy to control these and other ozone precursors.

\section{Volatlle Organic Compounds}

The mixing of urban $\mathrm{NO}_{\mathrm{x}}$, hydroxyl ions, and other precursors of ozone with biogenic VOCs in transport regions downwind of cities ${ }^{254}$ creates additional ozone. One large component of the biogenic VOCs is methane.

Methane $\left(\mathrm{CH}_{4}\right)$ results from many natural processes (e.g., vegetation and animal decay). Normally a gas, methane and its reaction products dominate the chemistry of the unpolluted troposphere. ${ }^{255}$ For this reason, and the fact that it has a relatively low reactivity, methane is often excluded from consideration as a tropospheric VOC pollutant. Although methane is a GHG, it is not on the list of chemical species to be controlled because the EPA has considered it relatively unimportant in local and regional ozone production. ${ }^{256}$ A category of chemical species called "nonmethane volatile organic compounds" are considered more manageable precursors to ozone. This category includes methanol, ethanol, formaldehyde, and a wide variety of other organic compounds.

\section{Hydroxyl lons (OH)}

In the atmosphere, in the presence of sunlight, some of the oxygen atoms in already present ozone ions $\left(\mathrm{O}_{3}\right)$ can combine with ambient hydrogen to produce hydroxyl radicals $\left(\mathrm{OH}^{-}\right)$. These radicals can then combine with other ions, elements, and compounds in a variety of chain reactions that can produce acidic compounds and even more ozone. Dissociation of water vapor into hydrogen and hydroxyl ions is a nonlinear function of temperature, pressure, and water vapor concentration. At the triple point, the temperature at which water vapor, liquid, and ice coexist in equilibrium, water has a dissociation constant of around $10^{-7}$, so there is always a steady supply of both hydrogen and hydroxyl ions.

While the background level of water vapor has regional swings, some urban canyons and stagnant air masses can have a water vapor buildup to a saturation level as a result of motor fuel combustion.

\section{Carbon Monoxide (CO)}

$\mathrm{CO}$ is emitted by vehicles as a result of incomplete combustion of fuel. Incomplete combustion occurs

Table 37. Emissions of Nitrogen Oxides and Nonmethane Volatile Organic Compounds by Source, 1991

\begin{tabular}{|c|c|c|c|c|}
\hline \multirow[b]{2}{*}{ Source } & \multicolumn{2}{|c|}{$\mathrm{NO}_{x}$} & \multicolumn{2}{|c|}{ Nonmethane VOCs } \\
\hline & Million Motric Tons & Percent of Total & Million Motric Tons & Percent of Total \\
\hline Highway Vehicles . . . . . . . . . & 5.38 & 29 & 3.82 & 23 \\
\hline Other Transportation $\ldots \ldots \ldots$ & 1.88 & 10 & 1.26 & 7 \\
\hline Stationary Source Combustion .. & 10.59 & 56 & 0.67 & 4 \\
\hline Industrial Processes $\ldots \ldots \ldots \ldots$ & 0.60 & 3 & 7.86 & 47 \\
\hline Solid Waste Disposal . . . . & 0.10 & 1 & 0.69 & 4 \\
\hline Miscellaneous . . . . . . . . . . & 0.21 & 1 & 2.59 & 15 \\
\hline Total $\ldots \ldots \ldots \ldots \ldots$ & 18.76 & 100 & 16.88 & 100 \\
\hline
\end{tabular}

Source: Energy Information Administration, Emissions of Greenhouse Gases in the United States 1985-1990, DOE/EIA-0573 (Washington, DC, September 1993), Tables 44 and 45, pp. 57 and 58.

\footnotetext{
${ }^{254}$ National Research Council, Rethinking the Ozone Problem in Urban and Regional Pollution (Washington, DC: National Academy Press, 1991), pp. 27-29.

${ }^{255}$ National Research Council, Rethinking the Ozone Problem in Urban and Regional Pollution, pp. 110-111.

${ }^{256}$ National Research Council, Rethinking the Ozone Problem in Urban and Regional Poilution, p. 224.
} 
when a fuel/air mixture is too rich, i.e., when too little air results in a nonstoichiometric mixture containing too little oxygen. This prevents complete oxidation of hydrocarbons present in the fuel. Hydrocarbons that remain unburned during this process are emitted into the air.

If the fuel/air mixture is too lean (too much air and not enough fuel), conditions are created in which excessive $\mathrm{NO}_{\mathrm{x}}$ is formed. Unfortunately, there is a fairly limited range of the fuel/air ratio in which all three pollutant categories-CO, $\mathrm{NO}_{\mathrm{x}}$, and VOCs-are minimized. Catalytic converters and afterburners are optimized to shift this range; when the catalytic converters fail, emissions increase.

If $\mathrm{CO}$ is inhaled, it enters the bloodstream, reducing oxygen supply to the body's organs and tissues. The individuals most seriously affected by $\mathrm{CO}$ are those with cardiovascular disease. Healthy individuals suffer ill effects at higher concentration levels. ${ }^{257}$

Due to regulatory strategies, $\mathrm{CO}$ emissions from all sources decreased by over 50 percent in the period $1970-1991{ }^{258}$ Only 13 metropolitan statistical areas exceeded the NAAQS standard for CO in 1991 (9 parts per million (ppm) for the second-highest non-overlapping 8-hour average concentration) (Table 38).

Oxygenated additives make reformulated fuels a current vanguard of EPA strategy to reduce $\mathrm{CO}$ nonattainment. Emissions of $\mathrm{CO}$ by highway vehicles were reduced by 45 percent between 1982 and 1991 despite a 36-percent increase in vehicle miles traveled in the same time period. ${ }^{259}$ The per-mile fuel economy increased in excess of the rate of the emissions reductions, while emissions control systems on new vehicles became more effective. Older vehicles left the vehicle populations, shifting the balance toward achievement of regulatory goals, especially the CAFE standards. Increased CAFE regulatory goals of greater miles per gallon are fairly linearly related to emission production, while the other strategies are distinctly nonlinear and region specific.

During the period from November 1992 through January 1993 in 20 areas utilizing oxygenated fuel, EPA carbon monoxide standards were only exceeded twice. However, during the same period 1 year before oxygenated fuels were introduced to the market under the EPA wintertime oxygenate program, the same areas exceeded Federal standards 43 times. ${ }^{260}$

Table 19 in Chapter 5 lists the number of $\mathrm{CO}$ events during which the limits were exceeded over the past six winter seasons.

\section{Table 38. Motropolitan Statistical Areas That Exceeded NAAQS Standards for Carbon Monoxide In 1991}

\begin{tabular}{|c|c|c|}
\hline Motropolltan Statiatical Area & $\begin{array}{c}1980 \\
\text { Population }\end{array}$ & $\begin{array}{c}\text { 8-hour CO } \\
\text { (ppm) }\end{array}$ \\
\hline Albuquerque, NM ......... & 481,000 & 10 \\
\hline Anchorage, AK . . . . . . . . & 226,000 & 10 \\
\hline Denver, CO ... & $1,623,000$ & 10 \\
\hline El Paso, TX .... & 592,000 & 11 \\
\hline Ft. Collins, CO ... & 186,000 & 10 \\
\hline Las Vegas, NV . . . . . . . . . . & 741,000 & 12 \\
\hline Los Angeles-Long Beach, CA . & $8,863,000$ & 16 \\
\hline Mediord, OR . . . . . . . . . . & 146,000 & 11 \\
\hline Minneapolis-St. Paul, MN-WI . . & $2,464,000$ & 11 \\
\hline San Jose, CA . . . . . . . . . & $1,498,000$ & 10 \\
\hline Spokane, WA . . . . . . . . . & 361,000 & 12 \\
\hline Steubenville, Wierton, $\mathrm{OH}-\mathrm{WV}$. & 143,000 & 14 \\
\hline Vancouver, WA ........... & 238,000 & 10 \\
\hline
\end{tabular}

Source: Adapted from U.S. Environmental Protection Agency, Office of Air Quality Planning and Standards, National Air Quality and Emissions Trends Report, 1991, 450-R-92-001 (Washington, DC, October 1992), Table 4-5, p. 4-22.

\section{Ozone Precursors: Nitrogen Oxides, Hydroxyl Radicals, and Volatile Organic Compounds}

Emission reduction programs over a 20 -year period have been successful in reducing ozone, but not to the degree required by EPA. While ozone emissions from all sources decreased by roughly 15 percent in the period 1970-1991, ${ }^{261}$ the number of ozone nonattainment areas with Extreme, Severe, and Serious classifications rose to 21 in 1991. Ozone is a photochemical oxidant responsible for serious environmental and

\footnotetext{
${ }^{257}$ U.S. Environmental Protection Agency, Office of Air Quality Planning and Standards, National Air Quality and Emissions Trends Report, 1991, 450-R-92-001 (Washington, DC, October 1992), p. 1-5.

${ }^{258}$ U.S. Environmental Protection Agency, Office of Air Quality Planning and Standards, National Air Quality and Emissions Trends Report 1991, p. 1-5.

${ }^{259}$ U.S. Environmental Protection Agency, Office of Air Quality Planning and Standards, National Air Quality and Emissions Trends Report 1991, p. 1-4.

${ }^{260}$ United Press International, News Release March 11, 1993 and Alcohol Outlook, March 1993, p. 2.

${ }^{261}$ U.S. Environmental Protection Agency, Office of Air Quality Planning and Standards, National Air Quality and Emissions Trends Report 1991, p. 1-5.
} 
health problems. Under certain meteorological conditions, $\mathrm{NO}_{x}$, hydroxyl ions $\left(\mathrm{OH}^{-}\right)$, and VOCs undergo reactions which produce ambient ozone at levels as great as three times that considered acceptable by EPA. In 1989, 67 million people lived in urban and rural areas where ozone exceeded the NAAQS standard $(0.12$ $\mathrm{ppm})^{262}$ Several areas of the country are in nonattainment for the NAAQS ozone standard (Table 39).

Ozone in the stratosphere absorbs ultraviolet light, which can cause skin cancer in humans and death in sensitive plants. Skin cancer risk increases to its maximum in tropical high-altitude summers in the Southern Hemisphere.
Due to its reactive nature, tropospheric ozone can cause impaired lung function and respiratory damage. ${ }^{263}$ Animal studies have demonstrated that ozone accelerates aging of the lungs. Ozone causes damage to trees and is responsible for several billion dollars annually in crop yield reductions.

What makes ozone (smog) so hard to control is the complexity of the chemistry which produces it. An atmospheric soup of elements and molecules result from both the activities of man and the processes of nature. These combine under a wide range of conditions to produce ozone. ${ }^{264}$ Some of these reactions are photochemically driven or are temperature sensitive.

Table 39. Ozone Nonattainment Areas and Related Air Quality Classification, 1991

\begin{tabular}{|c|c|c|}
\hline State & Nonattainment Area Name & $\begin{array}{l}1980 \text { Clean Air Act } \\
\text { Clasolfication }\end{array}$ \\
\hline 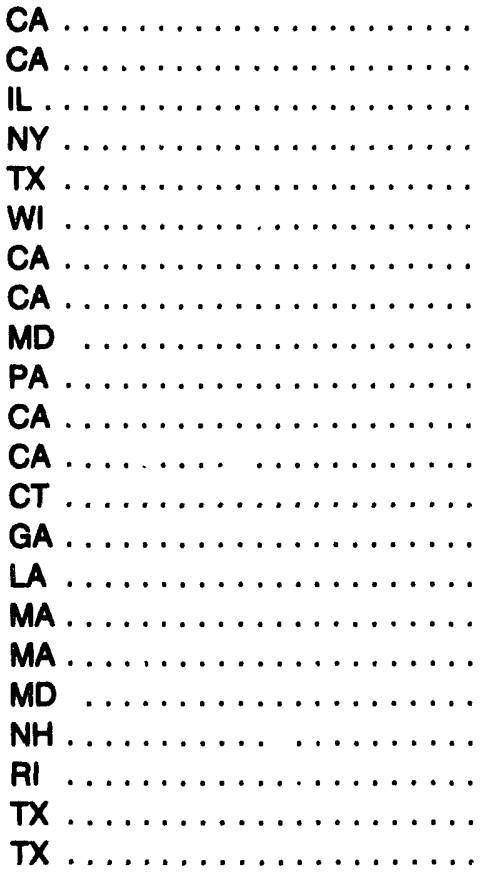 & $\begin{array}{l}\text { Los Angeles South Coast Air Basin } \\
\text { Southeast Desert Modified AQMD } \\
\text { Chicago-Gary-Lake County NA Area } \\
\text { New York-N. New Jersey-Long Island } \\
\text { Houston-Galveston-Brazonia NA Area } \\
\text { Milwaukee-Racine NA Area } \\
\text { San Diego NA Area } \\
\text { Ventura Co NA Area } \\
\text { Baltimore NA Area } \\
\text { Philadelphia-Wilmington-Trenton } \\
\text { Sacramento Metro NA Are } \\
\text { San Josquin Valley NA Area } \\
\text { Greater Connecticut NA Area } \\
\text { Atlanta NA Area } \\
\text { Baton Rouge NA Area } \\
\text { Boston-Lawrence-Worcester NA Area } \\
\text { Springtield (W. Mass) NA Area } \\
\text { Washington NA Area } \\
\text { Portsmouth-Dover-Rochester, NH } \\
\text { Providence (all of RI) NA Area } \\
\text { Beaumont-Pont Arthur NA Area } \\
\text { El Paso NA Area }\end{array}$ & $\begin{array}{l}\text { Extreme } \\
\text { Severe } \\
\text { Severe } \\
\text { Severe } \\
\text { Severe } \\
\text { Severe } \\
\text { Severe } \\
\text { Severe } \\
\text { Severe } \\
\text { Severe } \\
\text { Serious } \\
\text { Serious } \\
\text { Serious } \\
\text { Serious } \\
\text { Serious } \\
\text { Serious } \\
\text { Serious } \\
\text { Serious } \\
\text { Serious } \\
\text { Serious } \\
\text { Serious } \\
\text { Serious }\end{array}$ \\
\hline
\end{tabular}

Source: First Interim Report of the Federal Fleet Conversion Task Force, DOE/PO-0001 (Washington, DC, August 1993), Appendix K.

\footnotetext{
${ }^{262}$ National Research Council, Rethinking the Ozone Problem in Urban and Regional Pollution, pp. 1-2.

${ }^{253}$ U.S. Environmental Protection Agency, Office of Air Quality Planning and Standards, National Air Quality and Emissions Trends Report 1991, p. 1-11.

264 Manmade pollutants are referred to as anthropogenic emissions. Pollutants which are generated by the processes of nature are biogenic emissions. Biogenic emissions include VOCs generated by vegetation and animals.
} 
Therefore, the presence (and intensity) of sunlight is a major determinant in ozone $\left(\mathrm{O}_{3}\right)$ generation. For this reason, the most serious ozone concentrations occur in summer.

\section{Other Alr Pollutants from Transportation Fuels}

\section{Particulate Matter}

Conventional diesel-powered vehicles produce significant quantities of particulate matter ${ }^{265}$ and sulfur oxides. Particulates are the most harmful of the pollu- tants and, in addition, can be breathed more deeply into the lungs. While these pollutants have serious health effects, the number of diesel vehicles on the road is much sma'ler than spark ignition vehicles in terms of total highway vehicle population.

The current EPA standard for heavy-duty vehicle diesel engines for particulate matter is 0.10 grams per brakehorsepower-hour ( $\mathrm{g} / \mathrm{bhp}-\mathrm{hr}$ ). Diesel bus engines made in 1994 and 1995 will have to meet particulate standards of $0.07 \mathrm{~g} / \mathrm{bhp}-\mathrm{hr}$. Beginning in 1996, they will have to meet a standard of $0.05 \mathrm{~g} / \mathrm{bhp}-\mathrm{hr}$. In addition, all diesel vehicles in California are now required to use diesel fuel containing 80 percent less sulfur than conventional diesel fuel. ${ }^{266}$

\footnotetext{
${ }^{265}$ The component of the particulate matter category that is the most significant health hazard is PM-10, which consists of particulate matter of less than 10 micrometers. Particles of this size can cause respiratory problems when inhaled.

${ }^{266}$ Biodiesel Alert, Vol. 1, No. 4 (March 1993), p. 4.
} 
言

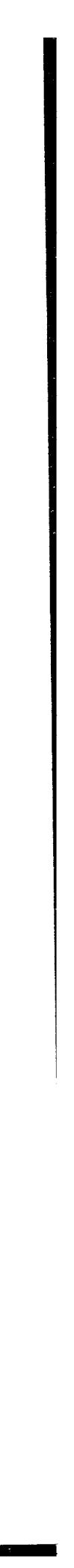




\section{Appendix A \\ State Government Initiatives}

Table A1. State Covernment Initiatives

\begin{tabular}{|c|c|c|}
\hline Sun & Altemulive Fucl Lews and Requiations & Alternasive Fuel Incentives \\
\hline Nabama.... & $\begin{array}{l}\text { While no specific altemative fuel legislation has been } \\
\text { adopted, the Energy Division of the Alabama Department of } \\
\text { Economic and Community Affairs will offer financial } \\
\text { assiatance for the installation of qualifying biomass energy } \\
\text { systems in commercial, industrial, or institutional facilities. }\end{array}$ & $\begin{array}{l}\text { Interest subsidies are available on loans used to finance } \\
\text { alternative fuel vehicle (AFVs) projects. The maximum } \\
\text { amount per project is } \$ 75,000 \text {. The project goal is to } \\
\text { reduce energy cost in the State by enhancing the market } \\
\text { for consumption of biomass fuels. } \\
\text { Assistance is also available from the Department of } \\
\text { Economic and Community Affairs for the conversion of fleet } \\
\text { vehicles to alternative fuels. The awards are available to } \\
\text { both government and private organizations and call for } 50 \\
\text { percent matching funds from the proposing organizations. }\end{array}$ \\
\hline Alaaka & No activity disclosed. & No activity disclosed. \\
\hline Arizona & $\begin{array}{l}\text { Arizona was the first State to issue a bid for AFVs. H.B. } \\
2433 \text { was enacted in } 1990 \text { and requires the State to } \\
\text { purchase AFV if their cost is within } 10 \text { percent of the total } \\
\text { life-cycle cost of a conventionally fueled vehicle. } \\
\text { The State is also required to implement a program to } \\
\text { replace State fleet vehicles with alternative fuel vehicles } \\
\text { (electric, solar electric, hydrogen, compressed natural gas } \\
\text { [CNG], liquetied natural gas [LNG], liquefied petroleum gas } \\
\text { [LPG], and alcohol fuels containing no less than } 85 \text { percent } \\
\text { alcohol by volume) at the rate of } 10 \text { percent per year for } \\
\text { new vehicles purchased beginning in } 1993 \text {. } \\
1992 \text { leglalation allows for the issuance of certificates to } \\
\text { licensed private fleet or vehicle owners for AFVs that will } \\
\text { qualify owners for lower vehicle registration/highway user } \\
\text { fees. This law expires on December } 31,1998 \text {. } \\
\text { In } 1993 \text {, emergency legislation was passed which } \\
\text { appropriated } \$ 4.9 \text { million dollars for retrofitting State fleet } \\
\text { vehicles and school buses. }\end{array}$ & $\begin{array}{l}\text { In } 1993, \mathrm{H} . \mathrm{B} .2095 \text { was enacted to provide deductions from } \\
\text { the Arizona gross income tax for certain costs associated } \\
\text { with purchasing AFVs and related equipment. Beginning in } \\
1994 \text {, taxpayers may adjust their gross income by } \\
\text { subtracting: } \\
\text { - } 25 \text { percent of the purchase price for one or more } \\
\text { new AFVs, not to exceed } \$ 5,000 \\
\text { - the cost of converting one or more vehicles to } \\
\text { operate on alternative fuel, not to exceed } \$ 3,000 \\
\text { - the purchase price of refueling equipment for } \\
\text { private, noncommercial use, not to exceed } \$ 5,000 \\
\text { - } 50 \text { percent of the interest paid or accrued or } \\
\text { indebtedness incurred to purchase AFVs (this } \\
\text { deduction must be taken in thirds over three taxable } \\
\text { years). } \\
\text { Another bill adopted in } 1993, \mathrm{H.B} \text {. } 2133, \text { exempts CNG and } \\
\text { LPG from various State taxes if used to propel a motor } \\
\text { vehicle. } \\
\text { The Department of Commerce Energy Office has provided } \\
\text { grants to Sun City Area Rapid Transit and the cities of } \\
\text { Glendale and Tucson to construct refueling stations and } \\
\text { vehicle conversions. } \\
\text { Through funding from an annual vehicle emissions } \\
\text { inspection fee, the Arizona Department of Environmental } \\
\text { Quality provides grants for communities and the State to } \\
\text { construct stations and convert vehicles to CNG. } \\
\text { Approximately } \$ 230,000 \text { is available for this program each } \\
\text { year. } \\
\text { A discount is avallable on the annual license tax rate to } \\
\text { electric vehicles. The vehicles are discounted at } \$ 4.00 \text { for } \\
\text { every } \$ 1,000 \text { of vehicle value. }\end{array}$ \\
\hline
\end{tabular}

See notes at end of table. 
Table A1. State Government Initiatives (Continued)

\begin{tabular}{|c|c|c|}
\hline State & Alternative Fuel Lawe and Requlatione & Alternative Fuol Incentives \\
\hline Arkansas & $\begin{array}{l}\text { The State established a nine-member Alternative Fuels } \\
\text { Commission to promote the development of alternative fuel } \\
\text { use in the State. }\end{array}$ & $\begin{array}{l}\text { A } \$ 250,000 \text { fund has been established for rebates on the } \\
\text { cost of converting vehicles to alternative fuels. The fund } \\
\text { provides for a rebate of } 25 \text { percent up to } \$ 1,000 \text { for CNG } \\
\text { and electric vehicle conversions and up to } \$ 500 \text { for } \\
\text { propane and alcohol conversions. }\end{array}$ \\
\hline California .... & 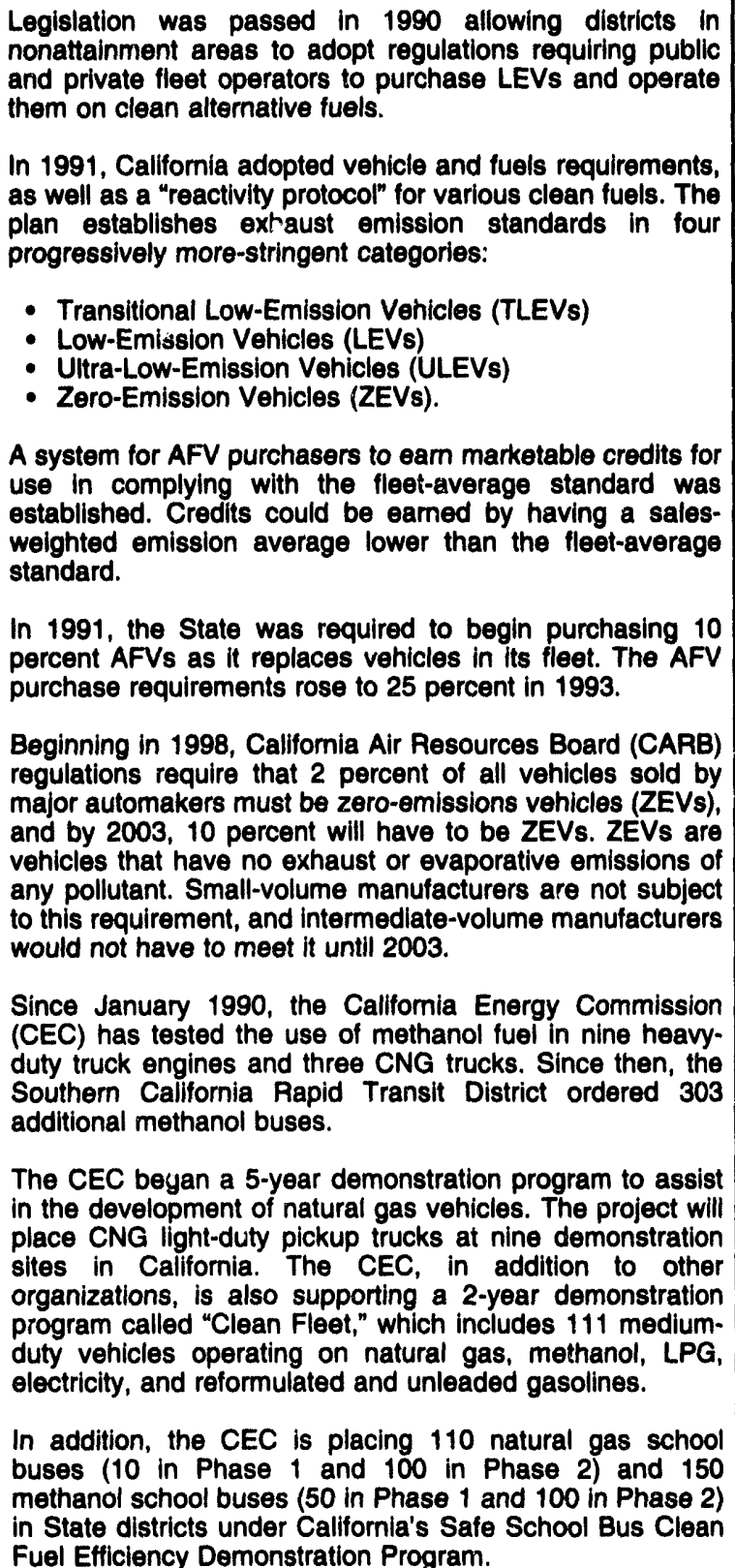 & $\begin{array}{l}\text { For tax years beginning January } 1,1991 \text { and ending } \\
\text { January } 1,1995, \mathrm{~S} \text {.B. } 2600 \text { allows a State tax credit of } 55 \\
\text { percent of the incremental cost of specifled vehicles and } \\
\text { retroflt devices certified to meet CARB low-emission } \\
\text { requirements. The tax credit is a maximum of } \$ 1,000 \text { per } \\
\text { automobile, motorcycle, or two-passenger vehicle, and } \\
\$ 3,500 \text { for a vehicle weighing more than } 5,750 \text { Ib. The tax } \\
\text { credit is limited to } \$ 750,000 \text {. } \\
\text { In } 1993 \text {, legislation was enacted to amend this tax credit to } \\
\text { extend it to the purchase price of nonrecreational vehicles } \\
\text { that are LEVs for use in nonroad applications through } \\
\text { January } 1,1996 \text {. } \\
\text { S.B. } 1006 \text { established a State sales tax exemption based } \\
\text { on the incremental cost of purchasing a certified LEV or } \\
\text { retrofit parts for conversion to a LEV. This provision expires } \\
\text { on Dec. } 31,1994 \text {. } \\
\text { The State also reduces the rate of excise taxation on } \\
\text { alcohol fuels, E-85 and M-85 (85 percent ethanoV15 } \\
\text { percent unleaded gasoline and } 85 \text { percent methanoV15 } \\
\text { percent unleaded gasoline, respectively), to one-half the } \\
\text { rate imposed on gasoline, due to their lower Btu content. } \\
\text { Legislation adopted in } 1993 \text { elliminated the expiration date } \\
\text { for this incentive. } \\
\text { In addition, the CEC offers a } \$ 400 \text { incentive to purchasers } \\
\text { of } 1993 \text { and } 1994 \text { model year flexible-fuel vehicles (FFVs), } \\
\text { including Ford Taurus FFV, Chevrolet Lumina (1993 only) } \\
\text { variable-fuel vehicles (VFVs), and Dodge Spirit/ylymouth } \\
\text { Acclaim FFV that run on M-85. Incentives for methanol- } \\
\text { powered and other clean AFVs are being offered by various } \\
\text { districts. } \\
\text { The Sacramento Metropolitan Air Quality Management } \\
\text { District offers } \$ 500 \text { worth of free M-85 fuel for both public } \\
\text { and private owners of FFVs that operate } 75 \text { percent of the } \\
\text { time in the air district. }\end{array}$ \\
\hline
\end{tabular}

See notes at end of table. 
Table A1. State Government Initiatives (Continued)

\begin{tabular}{|c|c|c|}
\hline Colorado & 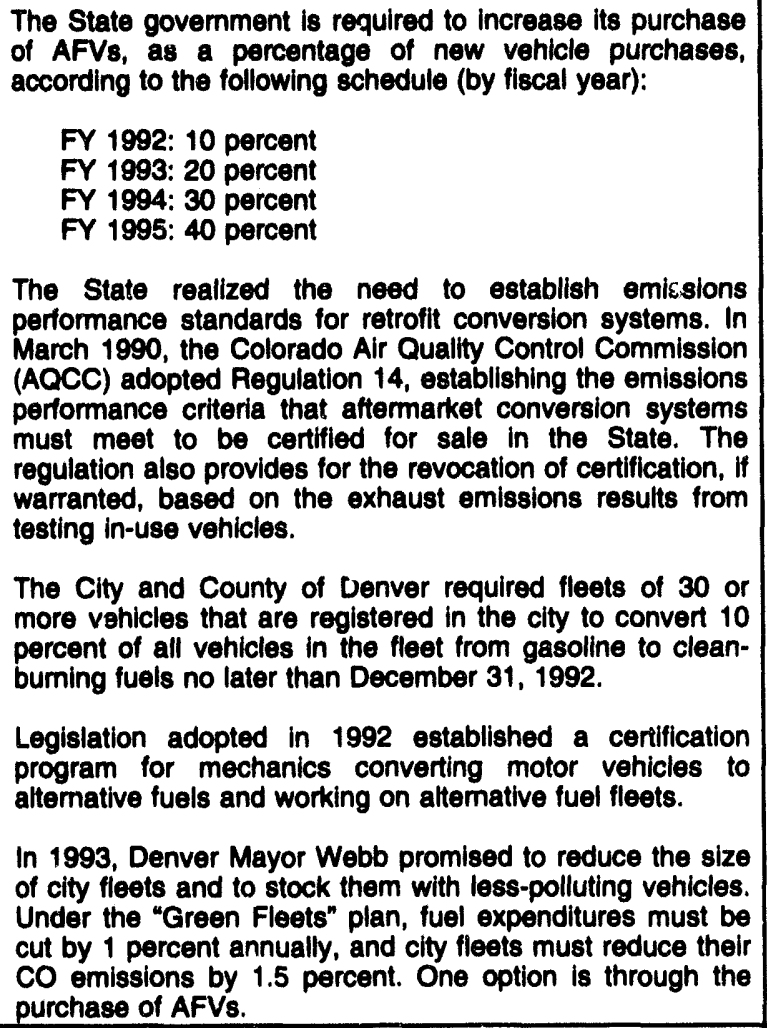 & $\begin{array}{l}\text { On July } 1,1992, \text { Colorado established an alternative fuels } \\
\text { financial incentive program to promote the conversion of } \\
\text { motor vehicles to the use of alternative fuels and to } \\
\text { promote the purchase of such vehicles in the State. } \\
\text { Under this program, the owner of any new or converted } \\
\text { motor vehicle is eligible to apply for such financial } \\
\text { incentives when the vehicle operates on CNG, propane, } \\
\text { electricity, or any other fuel that will achieve comparable } \\
\text { emission reduction levels. Financial incentives will be } \\
\text { graduated in amounts to provide greater rebates for those } \\
\text { vehicles that must reduce emissions of CO and brown- } \\
\text { cloud pollutants. The AQCC is to promulgate rules to } \\
\text { establish the amount of avallable incentlves. } \\
\text { In taxable years commencing on July } 1,1992 \text {, the State } \\
\text { has established a tax credit of } 5 \text { percent for the purchase of } \\
\text { business vehicles using clean-burning alternative fuels or a } \\
\text { vehicie converted to use alternative fuels within } 120 \text { days of } \\
\text { the date of delivery. Clean-buming alternative fuels are } \\
\text { defined as "natural gas, LPG, E-85, M-85, electricity, or any } \\
\text { other alternative fuel approved by the AQCC." }\end{array}$ \\
\hline Connecticut $\ldots$ & $\begin{array}{l}\text { Legislation was adopted in } 1990 \text { to require the State to } \\
\text { consider the purchase or conversion of its fleet of } \\
\text { alternative fuels. The State is joining other northeastern } \\
\text { States in adopting California exhaust emissions } \\
\text { specifications, which will encourage expanded use of } \\
\text { alternative fuels. } \\
\text { In } 1993 \text {, a bill was enacied requiring the State government } \\
\text { to use "clean fuel altematives" to gasoline in State-owned } \\
\text { vehicles. Clean fuel alternatives are those defined by the } \\
\text { Federal Clean Air Act. } \\
\text { Also in 1993, H.B. } 5418 \text { was enacted to facilitate } \\
\text { compliance with the } 1990 \text { Clean Air Act Amendments } \\
\text { (CAAA) and National Energy Policy Act (EPACT) through } \\
\text { the use of a cleaner fuel alternative to gasoline in State- } \\
\text { owned motor vehicles. Ten percent of all of the State's } \\
\text { 1993-1994 car and truck purchases are to be AFVs. } \\
\text { Connecticut provides a business tax credit until } 1997 \text { that } \\
\text { allows the Development Authority to provide vehicle } \\
\text { conversion loans. }\end{array}$ & $\begin{array}{l}\text { In } 1991 \text {, legislation was enacted to establish a 10-percent } \\
\text { tax credit for investments in AFVs or refueling } \\
\text { infrastructure, through } 1993 \text {. Such related purchases are } \\
\text { also exempt from the State sales and use tax. } \\
\text { S.B. } 982 \text {, enacted on June } 4,1993 \text {, reduces the tax on } \\
\text { propane used as a transportation fuel. } \\
\text { The State provides a } 1 \text { cent per gallon (c/gal) excise tax } \\
\text { exemption for } 10 \text { volume percent (volume percent) ethanol } \\
\text { (E-10) blends sold in the State. }\end{array}$ \\
\hline
\end{tabular}

See notes at end of table. 
Table A1. State Government Initiatives (Continued)

\begin{tabular}{|c|c|c|}
\hline Delaware ..... & $\begin{array}{l}\text { The Clean Cities/Clean State Committee has been } \\
\text { established to study the expanded use of altermative fuels } \\
\text { and the policies to implement a program in the future. } \\
\text { H.B. 51, enacted in 1993, eliminates the State motor fuels } \\
\text { tax on altemative fuels. } \\
\text { The State is implementing an AFV program and the State } \\
\text { energy office is concentrating on procurement of AFV for } \\
\text { the State fleet and light-duty for use in vehicles in the } \\
\text { Wilmington Metropolitan area. }\end{array}$ & No activity disclosed. \\
\hline $\begin{array}{l}\text { District of } \\
\text { Columhia ..... }\end{array}$ & 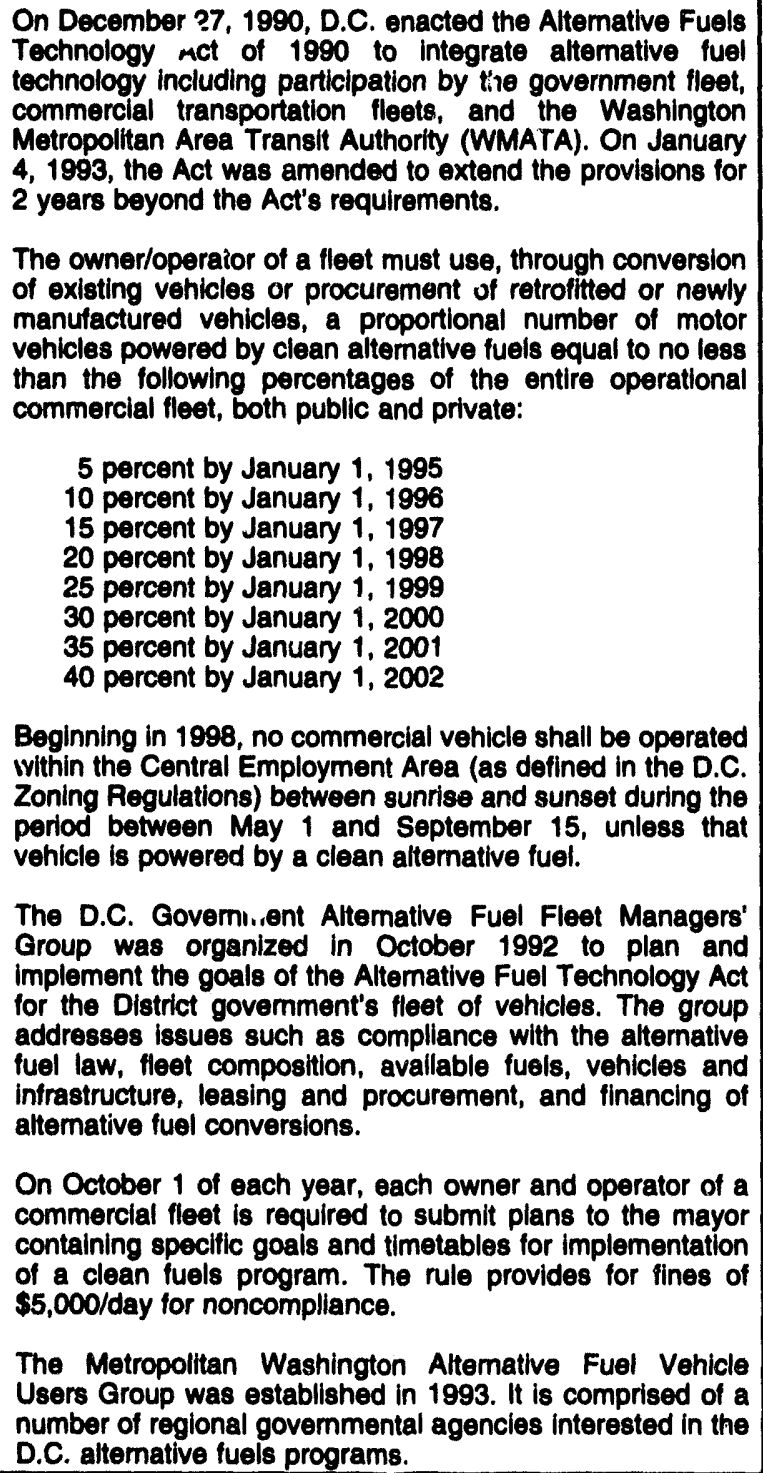 & No activity disclosed. \\
\hline
\end{tabular}

See notes at end of table. 


\section{Table A1. State Government Initlatives (Continued)}

\begin{tabular}{|c|c|c|}
\hline State & Alternative Fuol Lawe and Requlations & Altornative Fuol Incentivee \\
\hline Fiorida ....... & $\begin{array}{l}\text { On October } 8,1991 \text {, Gov. Lawton Chiles signed Executive } \\
\text { Order } 91-253 \text {, establishing a clean fuels pliot program and } \\
\text { encouraging the State to implement a program to convert } \\
\text { the State's fleet to alternative fuels. By } 2000 \text {, all State fleet } \\
\text { vehicles must operate on the "most efficient, least polluting" } \\
\text { alternative fuels. } \\
\text { H.B. } 461 \text {, enacted in } 1993 \text {, gives county governments } \\
\text { waste reduction credits for using yard trash, clean wood } \\
\text { waste or paper waste as feedstocks in the production of } \\
\text { clean-burning fuels such as ethanoi. }\end{array}$ & $\begin{array}{l}\text { S.B. 584, enacted in 1983, exempts certain suppliers of } \\
\text { CNG from regulation as a motor fuel. } \\
\text { The Florida Public Service Commission has determined } \\
\text { that the cost of CNG refueling stations would be rate- } \\
\text { based. } \\
\text { The Energy Office has been provided } \$ 1 \text { million in oil } \\
\text { overcharge funds to assist State agencies in meeting } \\
\text { alternative fuel fleet requirements. } \\
\text { Research and development funding is available for solar } \\
\text { and electric vehicles. }\end{array}$ \\
\hline Georgia & $\begin{array}{l}\text { Legislation enacted in } 1992 \text { removes authority from the } \\
\text { Public Service Commission to regulate trie sale of CNG to } \\
\text { the public for use as a motor fuel. } \\
\text { H.B. } 386 \text {, enacted in } 1993 \text {, provides for an additional fee for } \\
\text { a permit to dispense CNG for vehicular fuel. } \\
\text { The Environmental Protection Division of the Georgia } \\
\text { Department of Natural Resources has issued guidelines to } \\
\text { ensure CAAA and EPACT compliance with ultimate } \\
\text { conversion, to alternative fuels, of } 75 \text { percent of State } \\
\text { operated vehicles by the year } 2000 \text {. } \\
\text { The city of Atlanta has established "The Clean Air } \\
\text { Transportation-Atlanta," a Clean Cities organization, working } \\
\text { towards conversion of vehicles to alternative fuels. }\end{array}$ & $\begin{array}{l}\text { The } 1991 \text { alternativs fuels program allows for a } 3 \\
\text { yr./\$400,000 program of incentives to local government and } \\
\text { public transit authorities to convert fleets to alternative } \\
\text { fueis. } \\
\text { The Office of Energy Resources has awarded } \$ 500,000 \text { in } \\
\text { grants for conversion of fleets operated by public entities } \\
\text { with additional funding programs planned. }\end{array}$ \\
\hline Hawail & $\begin{array}{l}\text { State agencies are conducting studies on the costs and } \\
\text { benefits of phasing in use of AFVs into the State's fleets. In } \\
\text { addition, the State has encouraged the diversification of } \\
\text { ground transportation fuels around the State by government } \\
\text { and private organizations. }\end{array}$ & $\begin{array}{l}\text { Propane is the only highway fuel that receives a special } \\
\text { fuel tax rate (two-thirds that of diesel, rounded to the } \\
\text { nearest cent). Currently, this tax is } 11 \mathrm{c} / \mathrm{gal} \text { (the diesel fuel } \\
\text { tax is } 16 \mathrm{c} / \mathrm{gal} \text { ). Gasoline blended with } 10 \text { volume percent } \\
\text { biomass-derived alcohol sold in the State is exempt from } \\
\text { the 4-percent sales tax. }\end{array}$ \\
\hline Idaho ... & $\begin{array}{l}\text { In 1987, the governor issued a proclamation that all State } \\
\text { vehicles must be fueled with E-10 whenever practical. } \\
\text { Beginning in } 1992 \text {, at least } 5 \text { percent of new State vehicles } \\
\text { must be equipped to operate on alternative fuels, increasing } \\
\text { by } 10 \text { percent per year starting in } 1994 \text {. The public-sector } \\
\text { purchase of such vehicles can be financed under the terms } \\
\text { of the ldaho Energy Bank Program. }\end{array}$ & $\begin{array}{l}\text { Effective July } 1,1994 \text {, the State provides an excise tax } \\
\text { exemption for ethanol or biodiesel fuel, equivalent to } \\
2.1 \text { /gal of the biofuel. }\end{array}$ \\
\hline Illinois & $\begin{array}{l}\text { In 1987, the governor issued an executive order requiring } \\
\text { State vehicles to use E-10. State and local governments } \\
\text { have initiated pilot testing programs for E-85 and hybrid } \\
\text { diesel engine technologies. } \\
\text { On April 23, 1993, H.B. } 771 \text {, the Clean Altemative Fuels } \\
\text { and Conservation Act, was enacted to provide that by the } \\
\text { year } 2000,75 \text { percent of State-owned passenger cars, light } \\
\text { trucks, and vans would be capable of running on clean } \\
\text { alternative fuels. } \\
\text { In 1993, Resolution S.J.R. } 13 \text { passed. It encourages the } \\
\text { Federal Government to cooperate in funding research } \\
\text { intended to increase production and use of ethanol. }\end{array}$ & $\begin{array}{l}\text { The State provides a 2-percent sales tax exemption (on } \\
\text { average) statewide for } 10 \text { volume percent ethanol blends. } \\
\text { Effective July } 1,1992 \text {, all vehicles leased by any State } \\
\text { college or university must operate on gasoline blended with } \\
\text { E-10, whenever it is available. }\end{array}$ \\
\hline
\end{tabular}

See notes at end of table. 
Table A1. State Government Initiatives (Continued)

\begin{tabular}{|c|c|c|}
\hline State & Altornative Fuel Lawe and Requlations & Altornative Fuel Inoentres \\
\hline Indiana . . . . . . & 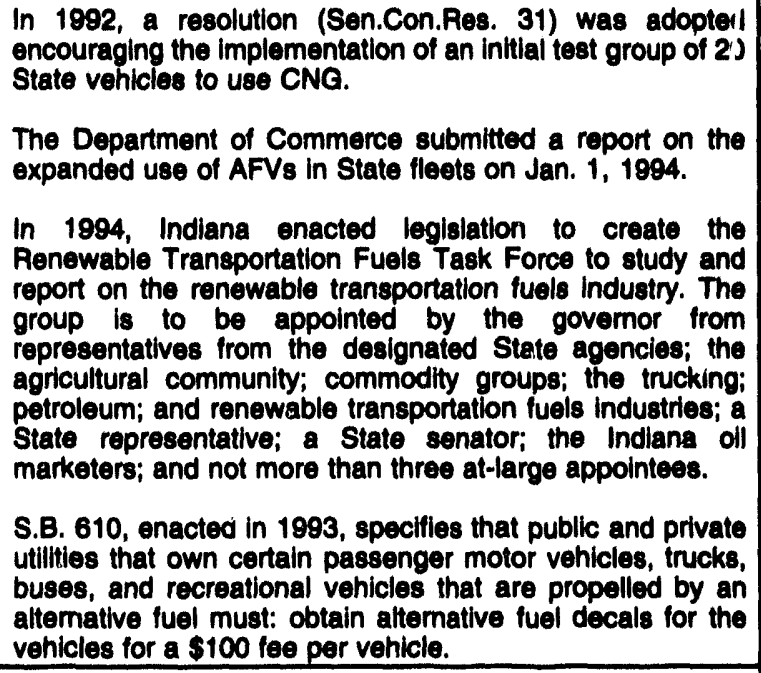 & $\begin{array}{l}\text { In 1993, H.B. } 1647 \text { was enacted to provide a price } \\
\text { preference of } 10 \text { percent for State and local govemment } \\
\text { procurement of "SoyDlesel." }\end{array}$ \\
\hline lowa & 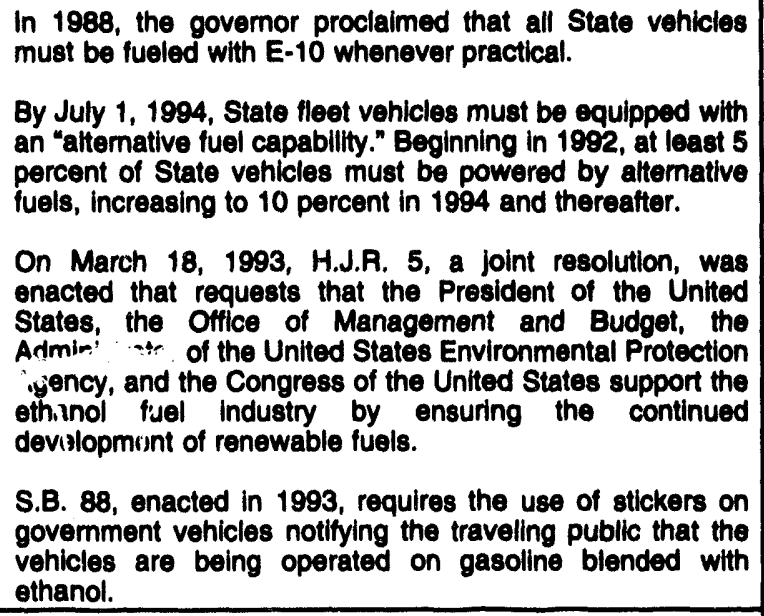 & $\begin{array}{l}\text { The State has established a Renowable Fuels Fund to } \\
\text { provide for the advancement of renowable fuels. Funding } \\
\text { has been provided for an ethanol incentive production } \\
\text { account. } \\
\text { The State provides } 14 / g a l \text { motor fuel excise tax exemption } \\
\text { for E-10. }\end{array}$ \\
\hline Kansas & $\begin{array}{l}\text { Executive Order } 92-152 \text { requires State agencies to use } \\
\text { altemative fuels in their vehicle fleets when cost-effective. }\end{array}$ & $\begin{array}{l}\text { The State provides a 3e/gal gasoline-equivalent tax } \\
\text { reduction on CNG and propane fuels. } \\
\text { The State also provides a direct incentive of up to } 20 \mathrm{a} / \mathrm{gal} \\
\text { for fuel ethanol produced in the State. }\end{array}$ \\
\hline Kentucky ..... & No activity disclosed. & $\begin{array}{l}\text { Legislation enacted in } 1892 \text { removes authortty from the } \\
\text { Public Service Commission to regulate the rates, terms, } \\
\text { and conditions for the sale of CNG as a transportation fuel } \\
\text { to an end user. }\end{array}$ \\
\hline
\end{tabular}

See notes at end of table. 
Table A1. State Covernment Initiatives (Continued)

\begin{tabular}{|c|c|c|}
\hline Stan & Altemetiv Fusl Lowe and Reculatione & Alternatlve Fuel Incentlves \\
\hline Louisiana & $\begin{array}{l}\text { In 1990, legislation (Act } 927 \text { ) was enacted to require that as } \\
\text { many as } 80 \text { percent of all State vehicles be converted to } \\
\text { operate on altemative fuels by } 1898 \text {. This provision was } \\
\text { later extended to all political subdivisions of the State. } \\
\text { Under this law, the phase-in requirement for government } \\
\text { purchase of AFVs is as follows: } \\
\text { 1994: } 30 \text { percent } \\
\text { 1995: } 30 \text { percent } \\
\text { 1996: } 50 \text { percent } \\
\text { 1997: } 50 \text { psrcent } \\
\text { 1998: as high as } 80 \text { percent } \\
\text { In March, } 1993 \text {, Gov. Edwards lssued an executive order } \\
\text { (EWE93-9) requiring the Department of Natural Resources } \\
\text { to issue requests for proposals to convert up to } 25 \text { percent } \\
\text { of the State fleet (about 1,500 vehicles) to the use of CNG, } \\
\text { LNG, or LPG. }\end{array}$ & $\begin{array}{l}\text { In } 1991 \text {, legislation was enacted to establish a 20-percent } \\
\text { income tax credit for conversion of vehicles to alternatlve } \\
\text { fuels and for refueling facilities. } \\
\text { The legislature also required the Public Service } \\
\text { Commission to deregulate the direct sale of CNG by } \\
\text { producers, plpelines, distribution companies, "or other } \\
\text { persons" when it is used as a transportation fuel. } \\
\text { In } 1992 \text {, legislation (H.B. } 527 \text { ) was enacted to extend the } \\
\text { tax credit to the purchase of qualified clean-buming motor } \\
\text { vehicles or for certain costs incurred to convert motor } \\
\text { vehicles to use certain alternative fuels. This law applies } \\
\text { only to vehicles registered in the State. } \\
\text { in } 1992 \text {, another bill (H.B. } 1282 \text { ) was enacted to reduce the } \\
\text { special fuels tax rate on CNG and LPG. The special fuels } \\
\text { tax was again lowered in 1993 for both CNG and LPG. }\end{array}$ \\
\hline Maine & $\begin{array}{l}\text { The State has joined other States in adopting Califomia } \\
\text { vehicle exhaust emissions requirements. }\end{array}$ & No activity disclosed. \\
\hline Maryland & $\begin{array}{l}\text { The Maryland Department of Environmental Protection is to } \\
\text { adopt the California LEV program by the } 2000 \text { model year. } \\
\text { Under a } 1993 \text { executive order, by } 1994,20 \text { to } 25 \text { percent of } \\
\text { new State fleet purchases are required to be powered by } \\
\text { alternative fuels. The order also establishes an "Alternative } \\
\text { Fuels Working Group" to make recommendations to the } \\
\text { govemor regarding the purchase and future plans for AFVs. }\end{array}$ & 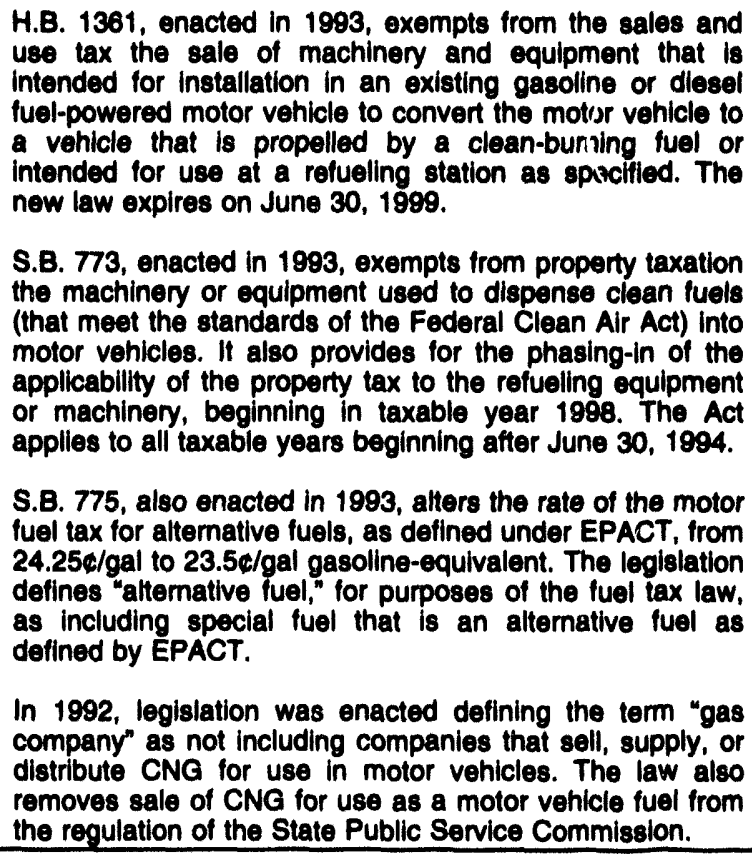 \\
\hline Massachusetts & $\begin{array}{l}\text { In 1990, the State enacted legislation adopting Calitomia } \\
\text { vehicle exhaust emissions requirements, phased-in starting } \\
\text { in } 1993 \text {. This legislation is currently the subject of appellate } \\
\text { iltigation in the Federal courts, after being upheld by the } \\
\text { U.S. District Court of Appeals for Massachusetts. }\end{array}$ & $\begin{array}{l}\text { The State excise tax on CNG and LPG, for on-highway } \\
\text { Use, is about 10e/gal, compared to the } 21 \mathrm{e} / g \text { al State excise } \\
\text { tax on gasoline. }\end{array}$ \\
\hline Mlchigan & $\begin{array}{l}\text { The Department of Management and Budget, Motor } \\
\text { Transport Section, has ordered } 10 \text { Chevrolet Luminas } \\
\text { designed to run on ethanol blends. The Michigan fleet } \\
\text { purchase for } 1993 \text { includes a total of } 69 \text { AFV. }\end{array}$ & $\begin{array}{l}\text { In 1993, the Michigan Public Service Commission approved } \\
\text { a settlement agreement that establishes an Experimental } \\
\text { Transportation Service Natural Gas Vehicie Refueling Rate. } \\
\text { There will be a temporary experimental tarif on the } \\
\text { transportation of natural gas for fueling vehicles that } \\
\text { includes a } \$ 950 \text { per month discount from the regular tariff. } \\
\text { The tariff expires on December } 31,1996 \text {. }\end{array}$ \\
\hline
\end{tabular}

See notes at end of table. 
Table A1. State Covernmont Initiatives (Continued)

\begin{tabular}{|c|c|c|}
\hline State & Altomative Ful Lawe and Requiations & Altomatlve Fuol incentlvee \\
\hline Minnesota & $\begin{array}{l}\text { In } 1993, \text { the govemor issued an executtve order requiring } \\
\text { that all State vehicles must be fueled with E-10 whenever } \\
\text { practicable. } \\
\text { Minnesota now requires that public fleets in cities with } \\
\text { populations of } 100,000 \text { or more convert to alternative fuel } \\
\text { use in new vehicles as follows: } \\
\text { FY 1995: } 10 \text { percent } \\
\text { FY 1996: } 15 \text { percent } \\
\text { FY 1997: } 25 \text { percent } \\
\text { FY 1998: } 50 \text { percent } \\
\text { FY 1899: } 75 \text { percent } \\
\text { FY 2000: } 90 \text { percent } \\
\text { Legislation adopted in } 1993 \text { requires that after October } 1 \text {, } \\
\text { 1993, all gasoline purchased in CO nonattainment areas } \\
\text { during CO-restricted-emission periods must contain } 2.7 \\
\text { weight percent oxygenates. After October } 1 \text {, 1995, all } \\
\text { gasoline purchased in CO nonattainment areas at any time } \\
\text { must contain } 2.7 \text { weight percent oxygen. After October } 1 \text {, } \\
\text { 1997, all gasoline sold in the State must contain } 2.7 \text { weight } \\
\text { percent oxygen. }\end{array}$ & $\begin{array}{l}\text { In } 1989 \text {, the State deregulated the use of natural gas as a } \\
\text { motor vehicle fuel. } \\
\text { The State provides a } 20 \mathrm{a} / \mathrm{gal} \text { incentive for producers of fuel } \\
\text { ethanol in the State and a } 24 / \text { gal excise tax exemption for } \\
10 \text { volume percent ethanol blended fuels sold in the State. }\end{array}$ \\
\hline Mississippi & No activity disclosed. & $\begin{array}{l}\text { In 1993, H.B. } 1098 \text { was enacted to deregulate natural gas } \\
\text { for use as a motor vehicle fuel. }\end{array}$ \\
\hline Missouri ...... & $\begin{array}{l}\text { In 1989, Gov. John Ashcroft issued an executive order } \\
\text { requiring that all State vehicles be fueled with E-10. } \\
\text { In 1991, Gov. Ashcroft enacted legislation requiring the } \\
\text { phase-in of State vehicles powered by altemative fuels, } \\
\text { beginning in 1995, according to the following schedule: } \\
\text { 1986: } 10 \text { percent } \\
\text { 1997: } 10 \text { percent } \\
\text { 1998: } 30 \text { percent } \\
\text { 1999: } 30 \text { percent } \\
2000: 50 \text { percent } \\
\text { By July 1, } 2000,30 \text { percent of all State venicles must be } \\
\text { operated solely on alternative fuels. } \\
\text { H.B. } 611 \text {, enacted in 1993, provides for the formation of an } \\
\text { ethanol and renewable fuels commission to attract these } \\
\text { products to the State, the act also provides a } 20 \mathrm{c} / g a l \\
\text { incentive for ethanol produced in the State. }\end{array}$ & $\begin{array}{l}\text { H.B. } 211 \text {, enacted in } 1993 \text {, Increases the tax paid by } \\
\text { owners of motor vehicles using alternative fuels from } \$ 8.50 \\
\text { to } \$ 8.00 \text { per year, and makes issued decals valid for } 15 \\
\text { days rather than } 3 \text { days. } \\
\text { The State provides a } 20 \mathrm{e} / \mathrm{gal} \text { incentive for fuel ethanol } \\
\text { produced in the State and a } 2 \mathrm{~g} / \mathrm{gal} \text { excise tax exemption } \\
\text { for E-10 sold in the State. }\end{array}$ \\
\hline Montana . & $\begin{array}{l}\text { The governor has issued a proclamation that all State } \\
\text { vehicles must be fueled with E-10, whenever practical. }\end{array}$ & $\begin{array}{l}\text { Enacted in } 1993, \text { S.B. } 374 \text { established a production-based } \\
\text { ethanol tax incentive if funding is avallable. } \\
\text { The State provides } 30 \mathrm{~g} / \mathrm{gal} \text { ethanol producer payment for } \\
\text { production of fuel in the State. }\end{array}$ \\
\hline Nebraska ..... & $\begin{array}{l}\text { In } 1979 \text {, the governor issued a proclamation that all State } \\
\text { vehicles must be fueled with E-10 whenever practical. }\end{array}$ & $\begin{array}{l}\text { The State has implemented a sophisticated program for the } \\
\text { development and promotion of ethanol blends and ethanot- } \\
\text { based ether. The State provides a 20/gal direct producer } \\
\text { incentlve for fuel ethanol produced in the State. The State } \\
\text { also provides a 50e/gal producer incentive for ethyl tertiary } \\
\text { butyl ether (ETBE) made from ethanol produced in the } \\
\text { State. }\end{array}$ \\
\hline
\end{tabular}

See notes at end of table. 
Table A1. State Covern..jent Initiatives (Continued)

\begin{tabular}{|c|c|c|}
\hline Stinte & Altomutive Fual Lewe and Requlations & Altomative Fuel Incontive \\
\hline Novada & 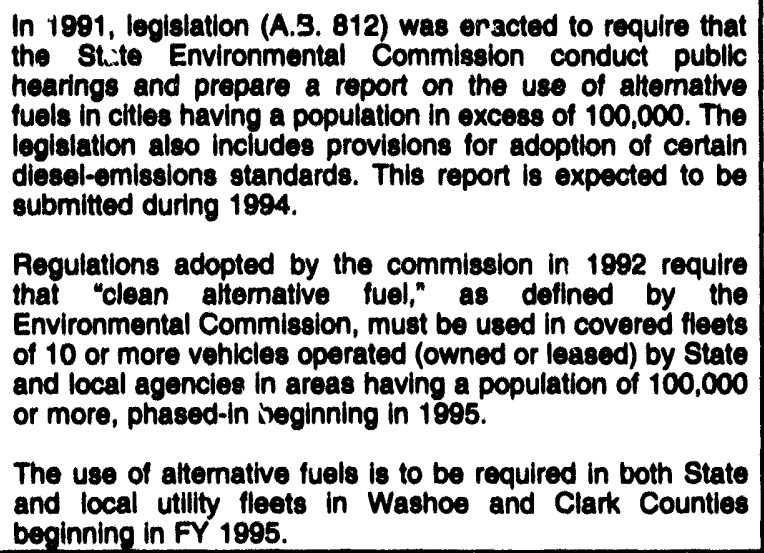 & $\begin{array}{l}\text { The excise tax on CNG and LPG use } J \text { as a transportation } \\
\text { fuel is equivalent to 18\%/gal (compared to } 22 \mathrm{egal} \text { for } \\
\text { gasoline sold in the State). } \\
\text { The fieet program provides for a credit system for the } \\
\text { acquisition of such vehicles in excess of the requirements } \\
\text { set forth in the regulations. }\end{array}$ \\
\hline $\begin{array}{l}\text { Now } \\
\text { Hampshire ..... }\end{array}$ & $\begin{array}{l}\text { The State is considering joining other States in adopting } \\
\text { California exhaust emissions requirements. }\end{array}$ & No actlvity disclosed. \\
\hline Now Jersey ... & $\begin{array}{l}\text { The State is considering joining other States in adopting } \\
\text { Califoria exhaust emissions requirements. }\end{array}$ & $\begin{array}{l}\text { Tax incentives are provided for LPG and CNG as } \\
\text { transportation fuels, including a fuel tax rate of } 5.25 \mathrm{c} / \mathrm{gal} \\
\text { equivalent, instead of the } 10.5 \mathrm{e} / \mathrm{gal} \text { excise tax on motor } \\
\text { fuels. }\end{array}$ \\
\hline New Mexico ... & $\begin{array}{l}\text { A bill enacted in } 1992 \text { (H.B. } 404 \text { ) required that } 30 \text { percent } \\
\text { or more of new State vehicle purchases must operate on } \\
\text { altemative fuels effectlve July, 1993; } 60 \text { percent in 1994; } \\
\text { and } 100 \text { percent in } 1995 \text { and later. } \\
1994 \text { legislation, H.B. } 940 \text {, provides for municipal and local } \\
\text { government ellibilility for loans from the Altemative Fuel } \\
\text { Conversion Fund for both infrastructure and vehicle } \\
\text { conversion and appropriates monies to the fund. } \\
\text { H.M. } 45 \text {, a memorial resolution enacted in February, 1994, } \\
\text { calls for a study of barriers to investment in CNG and LPG } \\
\text { as altemative motor vehicle fuels. The study is to be carried } \\
\text { out by an interim committee directed by the New Mexico } \\
\text { Leqisiative Council. }\end{array}$ & $\begin{array}{l}\text { The State has established a } \$ 5 \text { million loan fund for vehicle } \\
\text { conversions and has deregulated CNG when used as a } \\
\text { transportation fuel. } \\
\text { H.B. 462, enacted in 1993, places CNG under the } \\
\text { regulatory authority of the Liquefled Petroleum and } \\
\text { Compressed Gas Bureau of the Construction Industries } \\
\text { Division of the Regulation and Licensing Department. The } \\
\text { law also provides for private CNG- and LNG-powered } \\
\text { vehicles to pay an annual fee of } \$ 75 \text { in lleu of the State } \\
\text { motor fuel excise tax. }\end{array}$ \\
\hline Now York ..... & $\begin{array}{l}\text { New York established a 6-year, S40-million comprehensive } \\
\text { Alternative Fuel Vehicle Fleet Demonstration Program } \\
\text { (AFVFDP) in order to learn the practical requirements of } \\
\text { operating AFVs, determine their costs, and assist potential } \\
\text { users in adapting to the use of these vehicles. To } \\
\text { complement the AFV Program, the Energy Authority } \\
\text { conducts Research and Development projects aimed at } \\
\text { developing improved components for AFVs. } \\
\text { The goals of the AFVFDP include operating between } 250 \\
\text { and } 300 \text { AFVs in fleets to develop data on AFV emisions. } \\
\text { The Energy Authority is researching methanol, CNG, } \\
\text { propane, ethanol, oxygenated fuels, and electricity for } \\
\text { operation in a variety of AFVs including cars, light trucks, } \\
\text { transit buses, and garbage trucks. }\end{array}$ & $\begin{array}{l}\text { The State provides a partial tax exemption for the sale of } \\
\text { new AFVs and for vehicles that are converted to alternatlve } \\
\text { fuel use. }\end{array}$ \\
\hline North Carolina & $\begin{array}{l}\text { In 1991, leglslation was enacted that requires State } \\
\text { agencies to study the use of alternative fuels in State- } \\
\text { owned vehicles and establish a CNG demonstration project. }\end{array}$ & $\begin{array}{l}\text { Since 1987, the State has provided a corporate or personal } \\
\text { income tax credit for the construction of certain new fuel } \\
\text { ethanol plants in the State. }\end{array}$ \\
\hline
\end{tabular}

See notes at end of table. 
Table A1. State Government Initiatives (Continued)

\begin{tabular}{|c|c|c|}
\hline Stute & Altemative Fual Lawe and Requlatlons & Alternatlve Fuel Incentives \\
\hline North Dakota .. & $\begin{array}{l}\text { The governor has proclaimed that all State vehicles must } \\
\text { be fueled with E-10 when possible. }\end{array}$ & $\begin{array}{l}\text { In } 1993 \text {, H.B. } 1016 \text { was enacted to provide an appropriation } \\
\text { for fuel ethanol production incentives. It also provides an } \\
\text { appropriation from the alcohol motor vehicle fuel fund. } \\
\text { H.B. } 1429 \text {, also enacted in } 1993 \text {, provides an income tax } \\
\text { credit for equipment to convert motor vehicles to alternative } \\
\text { fuels and an income tax credit for alternative fuel refueling- } \\
\text { station equipment. } \\
\text { The State provides } 10 \text { percent of cost of conversion } \\
\text { equipment up to } \$ 200 / v e h i c l e \text { with gross vehicle weight } \\
\text { (gww) less than } 10,000 \mathrm{lb} ; 10 \text { percent of cost of conversion } \\
\text { equipment up to } \$ 500 / v e h i c l e \text { with gww greater than } 10,000 \\
\text { Ib. }\end{array}$ \\
\hline Onio & $\begin{array}{l}\text { In 1990, Gov. Aichard Celeste signed legislation directing } \\
\text { that fleets of three State agencies must be fueled with E-10. } \\
\text { Under the requirements of EPACT, the Ohio Department of } \\
\text { Transportation has initiated a CNG pilot project in } \\
\text { Cleveland involving } 20 \text { pickup trucks. } \\
\text { Under State legislation adopted in 1992, H.B. 201, Ohio has } \\
\text { established an Alternattve Fuels Advisory Council to } \\
\text { evaluate the use of altemative fuels in the State. A report } \\
\text { will be completed by June } 30,1994 \text {. }\end{array}$ & $\begin{array}{l}\text { The State provides a 1e/gal income tax credit for sale of } \\
\text { E-10. }\end{array}$ \\
\hline Oklahoma .... & $\begin{array}{l}\text { The } 1990 \text { Oklahoma Alternative Fuels Conversion Act was } \\
\text { the Nation's first State legislation to create an income tax } \\
\text { credit for the purchase or conversion of fleet vehicles to } \\
\text { alternative fuels, primarily CNG, LNG, propane, ethanol, } \\
\text { methanol (added to list of altemative fuels during 1993 } \\
\text { legislation), and electricity. It also established an Oklahoma } \\
\text { Alternative Fuel Revolving Fund to reimburse State, county, } \\
\text { and municipal governments and school districts for the } \\
\text { voluntary conversion of vehicles to altemative fuels. }\end{array}$ & $\begin{array}{l}\text { The State has deregulated the sale of CNG, LNG, and LPG } \\
\text { for use as motor vehicle fuels. Instead of paying a motor } \\
\text { fuel excise tax for these fuels, vehicles powered by them } \\
\text { are assessed a } \$ 100 \text { per vehicle fee annually (no sales tax } \\
\text { is imposed on CNG). } \\
\text { This law, revised in } 1991 \text {, includes a 50-percent tax credit } \\
\text { for the cost of conversion of vehicles to operate on } \\
\text { altemative fuels through January } 1,1993 \text {. A } 1992 \text { law, H.B. } \\
1193 \text {, extended this provision through January } 1,1995 \text {, } \\
\text { along with the } \$ 1.5 \text { million revolving no-interest loan fund } \\
\text { for vehicle conversions and refueling stations. } \\
\text { Private sector incentives are limited to natural gas: } 20 \text { - } \\
\text { percent credit for conversion equipment; } 20 \text {-percent credit } \\
\text { for refuelling equipment; 10-percent credit up to } \$ 1,500 \text { for } \\
\text { total cost of vehicle that features clean-fuel equipment } \\
\text { installed by a manufacturer. }\end{array}$ \\
\hline Oregon & $\begin{array}{l}\text { A bill adopted in } 1990, H . B .765 \text {, requires that after July } 1 \text {, } \\
1994 \text {, the State may only purchase vehicles designed to } \\
\text { operate on alternative fuels except in areas where the } \\
\text { fuel(s) are not economically available. In addition, H.B. } 766 \text {, } \\
\text { also adopted in } 1990 \text {, requires that mass-transit vehicles } \\
\text { purchased after July } 1,1993 \text { must be capable of operating } \\
\text { on altemative fuels, if technically and economically feasible. }\end{array}$ & $\begin{array}{l}\text { In 1991, legislation, H.B. } 2130 \text {, was enacted to establish an } \\
\text { income tax credit for the purchase or conversion of vehicles } \\
\text { to altemative fuels. The law expands energy conservation } \\
\text { tax credits to purchase AFVs and allows investor-owned } \\
\text { utilities to offer monies to customers to help purchase both } \\
\text { vehicles and infrastructure. }\end{array}$ \\
\hline Pennsylvania & $\begin{array}{l}\text { Since 1988, the Pennsylvania Energy Office has been } \\
\text { developing and implementing an alternative fuel fleet plan } \\
\text { involving } \$ 1 \text { million in grants and } 23 \text { public and private- } \\
\text { sector projects either in place or in the process of getting } \\
\text { under way. }\end{array}$ & $\begin{array}{l}\text { In 1993, Act 166, made effective the "Alternative Fuels } \\
\text { Incentive Grant Fund" to cover } 60 \text { percent of the } \\
\text { incremental cost of repowered vehicles and innovative } \\
\text { technologies, as well as conversion/retrofit costs or } \\
\text { purchase price of both vehicles and infrastructure needed } \\
\text { to operate alternative fuels. The fund is available to "school } \\
\text { districts, municipal authorities, political subdivisions, } \\
\text { nonprofit entities and corporations or partnerships } \\
\text { incorporated or registered" in Pennsylvania. The grant } \\
\text { funding amount is to be reduced } 10 \text { percent every } 2 \text { years } \\
\text { until it reaches } 20 \text { percent of the conversion/retrofit costs. } \\
\text { In addition, the legislation established a utilities' gross } \\
\text { receipts tax on gas utilities to provide funds for the } \\
\text { incentive grants. }\end{array}$ \\
\hline
\end{tabular}

See notes at end of table. 
Table A1. State Government Initlatives (Continued)

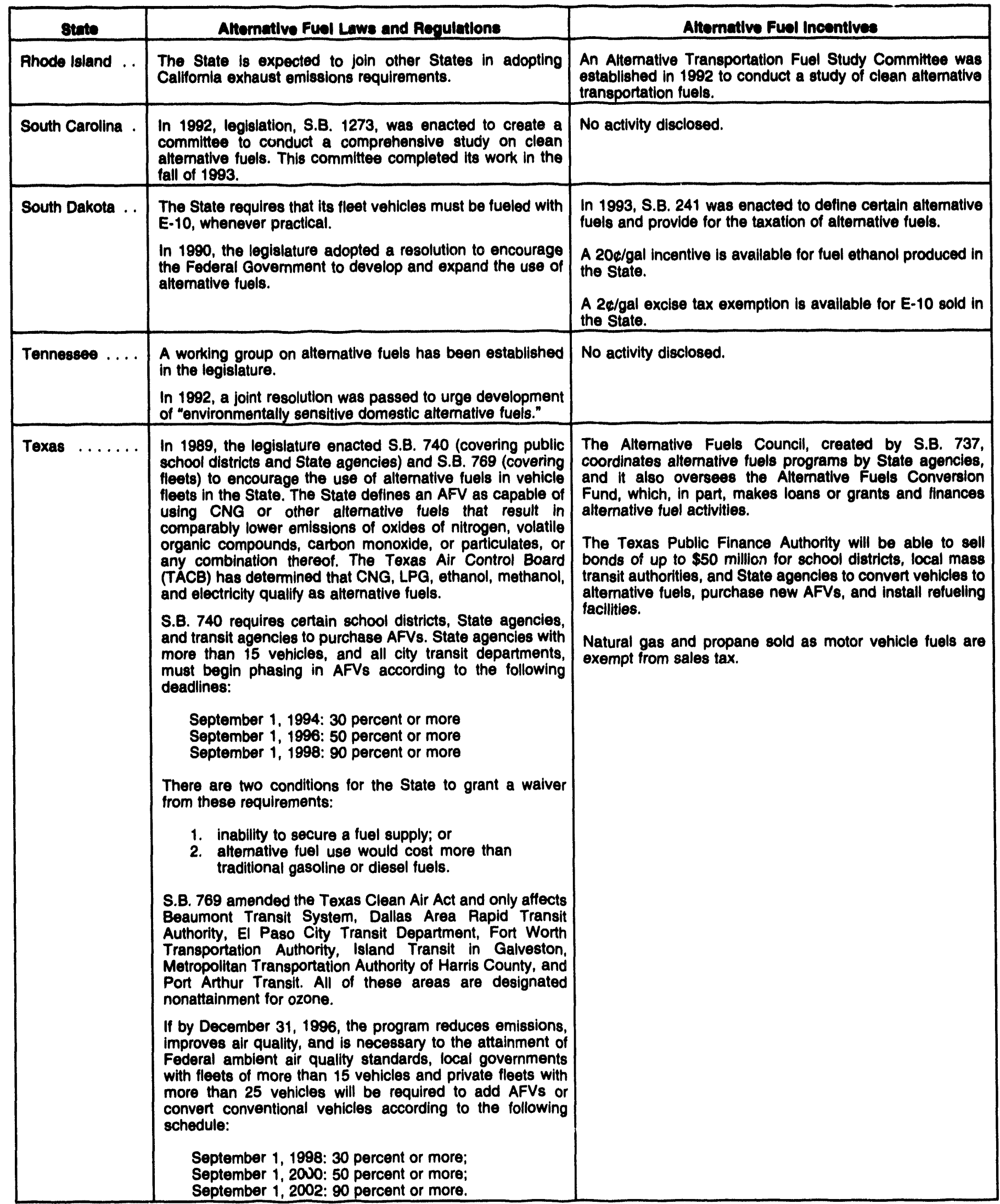

See notes at end of table. 
Table A1. State Government Initiatives (Continued)

\begin{tabular}{|c|c|c|}
\hline State & Aftornative Fuel Lawe and Requlations & Alternative Fuel Incentlves \\
\hline Utah & $\begin{array}{l}\text { After evaluation of pollution control strategies as a part of } \\
\text { the State implementation plan (SIP) demonstrating } \\
\text { attainment of the National Ambient Air Quality Standards } \\
\text { (NAAQS), the Air Quality Board has authority to require } \\
\text { fleets in specified geographical areas to use clean fuels } \\
\text { (propane, CNG, or electricity). } \\
\text { In order to require fleets to use clean fuels and thereby } \\
\text { assist the State in meeting NAAQS, the board must find the } \\
\text { use of a clean fuel is: } \\
\text { - necessary to demonstrate attainment and } \\
\text { maintenance of the NAAQS in any area where they } \\
\text { are required } \\
\text { - reasonably cost-effective when compared to other } \\
\text { similarty beneficial control strategies. } \\
\text { SIPs developed prior to July } 1,1995 \text {, may require fleets to } \\
\text { use clean fuels no earlier than July } 1 \text {, } 1995 \text {, unless the } \\
\text { boerd determines that fleet use of clean fuels is necessary } \\
\text { prior to that date to attain NAAQS. The board may not } \\
\text { require more than } 30 \text { percent of a fleet to use clean fuels } \\
\text { before January } 1,1998 ; 50 \text { percent before January } 1,1999 ; \\
\text { and } 70 \text { percent before January } 1,2000 \text {. }\end{array}$ & $\begin{array}{l}\text { The State provides a } 20 \text {-percent tax credit, } \$ 500 \text { maximum, } \\
\text { for each new dedicated vehicle registered in Utah and a } \\
\$ 400 \text { maximum for the cost of conversion equipment, if the } \\
\text { vehicle: } \\
\text { - Is fueled by propane, CNG, or electricity } \\
\text { - Is fueled by another fuel that the board has } \\
\text { determined is at least as effective in reducing air } \\
\text { pollution } \\
\text { - Meets Federal Clean Air Act requirements. } \\
\text { This tax credit applies to tax years beginning January } 1 \text {, } \\
1992 \text { and ending December } 31 \text {, } 1996 \text {. } \\
\text { The State has also established the Clean Fuels Private } \\
\text { Sector Vehicle Loan Fund, which provides low-interest } \\
\text { loans to private businesses and no-interest loans to public } \\
\text { fleet owners (vehicles owned and operated by the State, } \\
\text { local governments, or a public transit authority). } \$ 330,000 \\
\text { was appropriated for the } 1994-1995 \text { fiscal years. } \\
\text { The maximum loan for vehicles is between } \$ 4,000 \text { and } \\
\$ 18,000, \text { depending on vehicle size. The maximum loan for } \\
\text { refueling equipment is } \$ 250,000 \text {. The program is designed } \\
\text { as an incentive to: } \\
\text { - Purchase vehicles manufactured to operate on } \\
\text { cleaner buming fuels } \\
\text { - Convert vehicles to use cleaner burning fuels } \\
\text { - Purchase refueling equipment. }\end{array}$ \\
\hline Vermont . & $\begin{array}{l}\text { The State is expected to join other States in adopting } \\
\text { Califomia exhaust emissions requirements. } \\
\text { The Department of Public Service published the Vermont } \\
\text { Comprehensive Energy Plan in January } 1991 \text {. The strategy } \\
\text { was "to introduce cleaner fuels and alternative vehicles that } \\
\text { reduce or eliminate emissions." } \\
\text { In } 1993 \text {, legislation was enacted calling for State agencies } \\
\text { to consider the purchase of AFVs when purchasing new } \\
\text { vehicles. }\end{array}$ & No activity disclosed. \\
\hline
\end{tabular}

See notes at end of table. 
Table A1. State Covernment Initiatives (Continued)

\begin{tabular}{|c|c|c|}
\hline Stato & Altornathe Fuol Leme and Requitations & Alternative Fuol Incentives \\
\hline Virginia & $\begin{array}{l}\text { In } 1991 \text {, the Virginia legislature enacted a series of bills to } \\
\text { establish alternative fuel pilot projects, school bus engine } \\
\text { conversion programs, and refueling station conversion } \\
\text { incentives. } \\
\text { S.B. } 809 \text { and H.B. } 1788 \text { were companion bills, enacted in } \\
1993 \text {, that provide for a Clean Fuel Fleet Program, pursuant } \\
\text { to the CAAA, for Northem Virginia, Greater Richmond, and } \\
\text { Hampton Roads. Beginning with the } 1998 \text { model year (or } \\
\text { the first succeeding model year for which adoption of } \\
\text { standards is practicable), a certain percentage (based on } \\
\text { vehicle weight) of purchases of new fleet vehicles by } \\
\text { owners of centrally fueled fleet vehicles registered, based } \\
\text { or having a majority of their travel in the aftected localities, } \\
\text { would be required to be clean fuel vehicles. }\end{array}$ & 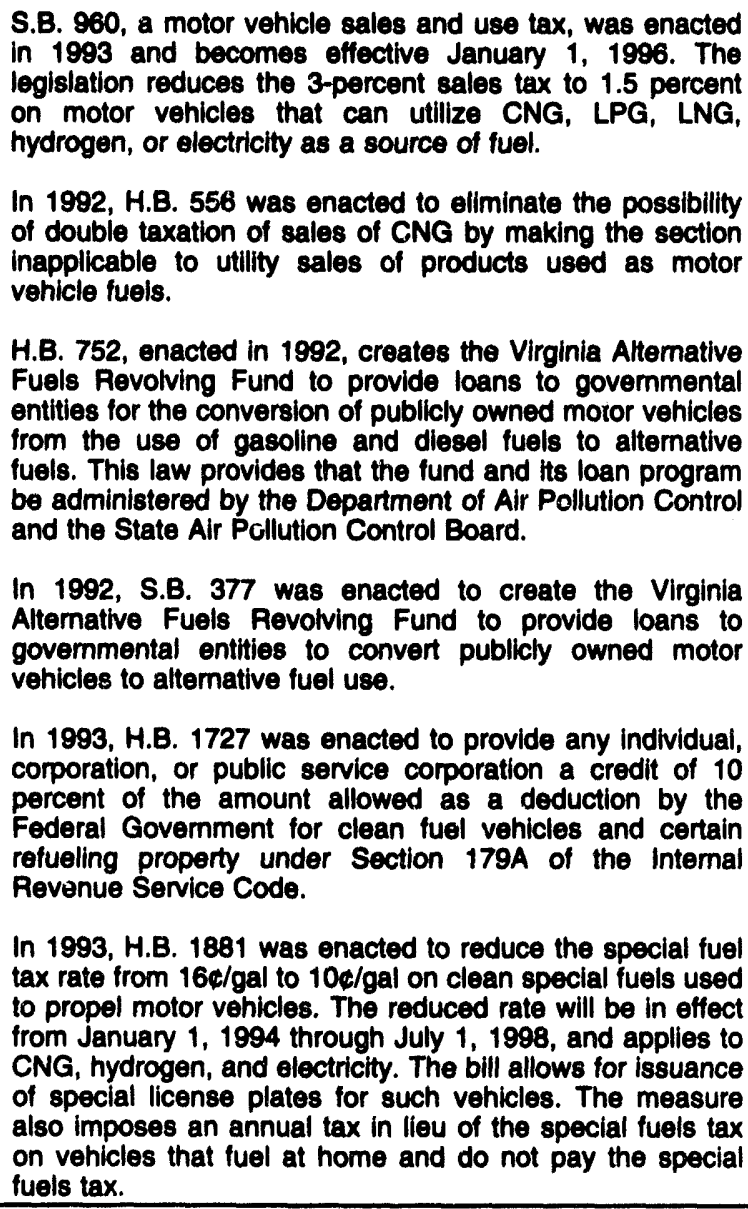 \\
\hline Washington ... & $\begin{array}{l}\text { Legislation adopted in 1991, H.B. 1028, requires that } 30 \\
\text { percent of new State vehicles purchased after July } 1,1992 \\
\text { must be LEVs, with the purchase requirement increasing by } \\
5 \text { percent in each subsequent year, and a preference for } \\
\text { "dedlcated" neat fuel vehicles, according to the following } \\
\text { schedule: } \\
\text { 1993: } 35 \text { percent } \\
\text { 1994: } 40 \text { percent } \\
\text { 1995: } 45 \text { percent } \\
\text { 1996: } 50 \text { percent } \\
\text { 1997: } 55 \text { percent } \\
\text { 1998: } 60 \text { percent } \\
\text { 1999: } 65 \text { percent } \\
\text { 2000: } 70 \text { percent }\end{array}$ & $\begin{array}{l}\text { The State provides air pollution control fund matching } \\
\text { grants to offset the purchase and operating costs to local } \\
\text { governments that voluntarily decide to switch to clean fuel } \\
\text { vehicles for public transport. } \\
\text { State law also provides that "for-hire" vehicles powered by } \\
\text { alternative fuels are waived from } 1991-1996 \text { licensing fees. } \\
\text { CNG- and LPG-powered vehicles are required to pay an } \\
\text { annual fee of } \$ 85 \text { instead of the fuel being subject to motor } \\
\text { fuel excise taxes. } \\
\text { A } \$ 750,000 \text { fund has been established to provide for the } \\
\text { development of a public infrastructure for CNG refueling } \\
\text { stations. } \\
\text { H.B. } 2326 \text {, enacted April 1, } 1994 \text {, eliminates the States tax } \\
\text { credits for ethanol blends, effective May } 1,1994 \text {. }\end{array}$ \\
\hline
\end{tabular}

See notes at end of table. 
Table A1. State Government Initiatives (Continued)

\begin{tabular}{|c|c|c|}
\hline Sthe & Altomntwe Fud Lawe and Requlatlons & Atomative Fual Ineontives \\
\hline West Virginia .. & $\begin{array}{l}\text { In 1991, the govemor lssued an executive order } \\
\text { establishing a natural gas vehicle test program, including } \\
\text { natural gas fueling stations, in addition to a State law } \\
\text { requiring the Public Service Commission to establish } \\
\text { demonstration and infrastructure programs for CNG, } \\
\text { methanol, and electric vehicles. } \\
\text { State agencies must purchase AFVs complying with the } \\
\text { following schedule: } \\
\text { FY 1995: } 20 \text { percent } \\
\text { FY 1996: } 30 \text { percent } \\
\text { FY 1997: } 50 \text { percent }\end{array}$ & $\begin{array}{l}\text { The sale of CNG as a motor fuel has been deregulated by } \\
\text { the State. }\end{array}$ \\
\hline Wisconsin $\ldots$. & $\begin{array}{l}\text { Gov. Tommy Thompson established an Altemative Fuels } \\
\text { Task Force in September, 1990. The mission of the task } \\
\text { force is to evaluate CNG, ethanol, propane, methanol, } \\
\text { reformulated gasoline, LNG, electricity, and hydrogen as } \\
\text { aftemative fuels. } \\
\text { The Task Force administers the Local Govemment } \\
\text { Altematlve Fuels Cost-Sharing Program, establishes an } \\
\text { alternative-fuel research laboratory, and is developing an } \\
\text { Altemative Fuels Economic Development Strategy. Also } \\
\text { included is a phased-in program involving propane, CNG, } \\
\text { ethanol, and methanol. } \\
\text { S.B. } 508, \text { enacted in 1993, requires the use of alternative } \\
\text { fuels in vehicles owned by political subdivisions. } \\
\text { By executive order, Gov. Thompson, has established the } \\
\text { "2,000 by } 2000 \text { plan that is intended to purchase } 2,000 \\
\text { AFV8, for State use, by the year } 2000 \text {, exceeding the } \\
\text { EPACT requirements. }\end{array}$ & $\begin{array}{l}\text { A law enacted in } 1984 \text { deregulated the use of natural gas } \\
\text { as a motor fuel. } \\
\text { The State has initiated public-private partnerships to } \\
\text { stimulate ethanol, CNG, and propane fuels infrastructure } \\
\text { and use. }\end{array}$ \\
\hline Wyoming .... & $\begin{array}{l}\text { The State requires that its fleet vehicles must be fueled with } \\
\text { E-10, whenever practical. } \\
\text { The State energy section is coordinating projects in } \\
\text { Cheyenne, Casper, Laramie, Pock Springs, and Sheridan } \\
\text { countles into a statewide plan to demonstrate the feasibility } \\
\text { of CNG-powered fleet vehicles in the State. }\end{array}$ & $\begin{array}{l}\text { Effective July 1, 1989, the State enacted legisiation } \\
\text { reestablishing a } 4 \mathrm{c} / \mathrm{gal} \text { tax incentive for E-10. }\end{array}$ \\
\hline
\end{tabular}

Note: This may not cover all initiatives on all alternative transportation or replacement fuels.

Source: The National Alternative Fuels Hotline for Transportation Technologies. 


\section{Appendix B Explanatory Notes}

The Energy Information Administration (EIA) currently collects limited information on alternative fueled vehicles (AFVs), alternative transportation fuels (ATFs), and replacement fuels. Thus, the information in this report relies heavily on secondary sources (Table B1). The quality of the data estimates contained in this report is summarized in this appendix in a limited fashion (Table B2). However, EIA is in the process of modifying existing surveys and, where necessary, will design new collection instruments to collect pertinent data. Once data are collected, the EIA will then be able to assess more adequately the estimates that are published in this report.

\section{Data Quality Assessment}

\section{Federal}

The quality of data for alternative fueled vehicles and fuel usage is fairly reliable for the information obtained from the General Services Administration (GSA). The GSA can track fuel usage for methanol and ethanol through their credit card system. The EIA collects and has available data on methyl tertiary-butyl ether (MTBE) and ethanol production, and on natural gas as it pertains to transportation fuel. Compressed natural gas fuel consumption is tracked by the gas companies serving the region where Federal AFVs are located. AFV counts and fuel consumption for Federal agencies that purchase vehicles and convert them to AFVs rather than leasing through GSA are less reliable, because the EIA can only obtain the information from a small sample of agencies.

\section{Non-Federal}

The quality, availability, compatibility, and general usefulness of the data on ATFs and AFVs are highly variable, and the data are rarely available at the desired level of detail and disaggregation. Also, fuel consumption and fuel displacement estimates are, in general, much less accurate than implied by precise vehicle counts and conventional fleet fuel use estimates. Reasons for these inaccuracies include the following: (1) non-ATF use in dual-fueled vehicles, (2) below-average use of AFVs in all fleets (excluding LPG) ${ }^{267}$ (3) uncertainty over fleet/nonfleet fractions for many States, and (4) inconsistency between DOE/EIA transportation fuel use estimates and information from industry staff or implied per-vehicle averages.

Data were obtained for the most part through a nongovernment study. Alternative fueled vehicle associations and fuel suppliers provided their data for 1992 and a "best guess effort" as an estimate for 1994.

Data were not obtained for 1993 for the following reasons. First, it was not a completed year at the time of the study. Estimation would have been difficult because the AFVs and replacement fuels are not well established and their market is very dynamic. For example, EPACT legislation provided tax deductions for ATF equipment placed in service on or before July 1, 1993. According to the Natural Gas Vehicle Coalition, the "placed in service" date has caused confusion that has resulted in delays in both ordering vehicles and developing refueling stations. These deferments are expected to have been stalled, but completed by the end of 1994.

\footnotetext{
${ }^{267}$ There is some evidence that AFVs do not travel as far as conventional vehicles-more repairs, more break-in periods, user opposition, and use on light routes.
} 


\section{Methodology}

Table B1. Methodology for Reporting Alternative Fueled Vehicle and Replacement Fuel Data

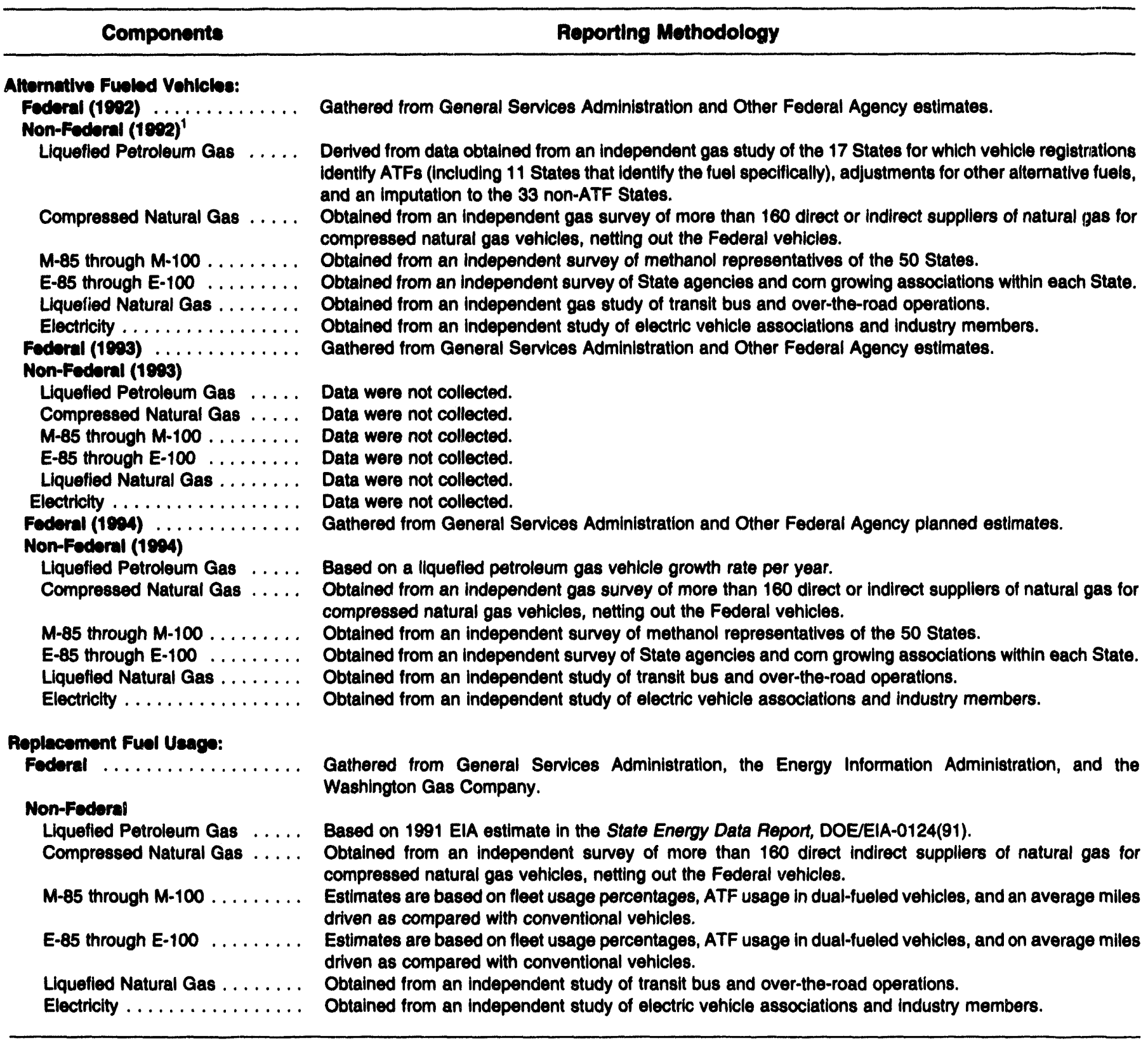

${ }^{1}$ Includes State and local government, private fleet, and nonprivate fleet data. 
Table B2. Summary of Information on Data Quality for Non-Federal Alternative Fueled Vehicles

Fuel

Ascesement

\begin{tabular}{|c|c|}
\hline & 1992 Vohicle Counts \\
\hline \multirow[t]{2}{*}{ Liquefied Petroleum Gas . . . . . . . . . } & $\begin{array}{l}\text { A minimum lower bound. Based on discussion with the LPG industry, counts may be up to } 50 \text { percent } \\
\text { greater. Because there are differences in taxation and regulation between on-road and off-road vehicles, } \\
\text { there are numerous incentives for vehicle owners to misreport vehicle status. }\end{array}$ \\
\hline & 1992 Vohlele Counte \\
\hline Compressed Natural Gas ........ & $\begin{array}{l}\text { Accuracy expected to be very high. There was a 100-percent enumeration of large fuel suppliers of natural } \\
\text { gas for compressed natural gas in the United States and at least } 98 \text { percent of all suppliers of natural gas } \\
\text { for compressed natural gas vehiclss. }\end{array}$ \\
\hline M-85 through $M-100 \ldots \ldots \ldots$ & $\begin{array}{l}\text { Accuracy expected to be very high. The counts were based on State-by-State enumerations; the majority } \\
\text { of vehicles are in California. }\end{array}$ \\
\hline E-85 through E-100 $\ldots \ldots \ldots \ldots$ & $\begin{array}{l}\text { There are some data uncertainties. Vehicle data collection is more difficult, because there is no large } \\
\text { concentration of this type of vehicle. }\end{array}$ \\
\hline Liquefied Natural Gas . . . . . . . . . . & $\begin{array}{l}\text { Vehicle counts are accurate, because ownership of these vehicles is concentrated at transit bus companies } \\
\text { and a few truck operations. }\end{array}$ \\
\hline Electricity $\ldots \ldots \ldots \ldots \ldots \ldots$ & $\begin{array}{l}\text { Uncertainties exist with respect to vehicle counts, because data are dificult to obtain. } \\
1894 \text { Vohlole Counts }\end{array}$ \\
\hline Liquefled Petroleum Gas . . . . . . . . . & $\begin{array}{l}\text { A reasonable lower bound. Based on discussion with the LPG industry, counts may be up to } 50 \text { percent } \\
\text { greater. Because there are differences in taxation and regulation between on-road and off-road vehicles, } \\
\text { there are numerous incentives for vehicle owners to misreport projected vehicle status. }\end{array}$ \\
\hline Compressed Natural Gas . . . . . . . & $\begin{array}{l}\text { Data are uncertain; Some respondents provided tentative estimates, while others provided estimates from } \\
\text { firm program plans. }\end{array}$ \\
\hline M-85 through $M-100 \ldots \ldots \ldots$ & Accuracy is very high. The estimates were based on responses from State methanol representatives. \\
\hline E-85 through E-100 $\ldots \ldots \ldots \ldots$ & $\begin{array}{l}\text { Data are uncertain. Estimates are difficult to obtain because there is no large concentration of this type } \\
\text { of vehicle. }\end{array}$ \\
\hline Liquefied Natural Gas . . . . . . . . . & $\begin{array}{l}\text { Vehicle estimates are accurate, because ownership of these vehicles is concentrated at transit bus } \\
\text { companies and a few truck operations. }\end{array}$ \\
\hline \multirow[t]{2}{*}{ Electricity $\ldots \ldots \ldots \ldots \ldots \ldots$} & Uncertainties exist with respect to vehicle estimates, because data are difficult to obtain. \\
\hline & Fuel Ueage (1992 and 1924) \\
\hline Liquefied Petroleum Gas . . . . . . . . . & $\begin{array}{l}\text { Highly uncertain, but reasonable; Because there are differences in taxation and regulation between on-road } \\
\text { and off-road vehicles, there are numerous incentives to misreport. }\end{array}$ \\
\hline Compressed Natural Gas ........ & $\begin{array}{l}\text { Data are uncertain; Many natural gas suppliers do not know the vehicle use. Some do not meter the fuel } \\
\text { use or track it at the compressor station. }\end{array}$ \\
\hline M-85 through $M-100 \ldots \ldots \ldots$ & $\begin{array}{l}\text { Estimates of fuel consumption are subject to fuel mix uncertainties because it can be used in dual-fueled } \\
\text { vehicles. }\end{array}$ \\
\hline \multirow[t]{2}{*}{ E-85 through E-100 $\ldots \ldots \ldots \ldots$} & $\begin{array}{l}\text { Estimates of fuel consumption are questionable not only because of fuel mix uncertainties, but ethanol as } \\
\text { a component of gasohol is also consumed in conventional vehicles. }\end{array}$ \\
\hline & Fuel Usage (1892 and 1994) \\
\hline Liquefied Natural Gas . . . . . . . . . & $\begin{array}{l}\text { Data are variable, because local natural gas companies are not a source for fuel information as they are } \\
\text { for compressed natural gas. The estimates also vary because many of the vehicles are in early } \\
\text { demonstration testing. }\end{array}$ \\
\hline Electricity . . . . . . . . . . . . & Uncertainties exist with respect to fuel usage. \\
\hline
\end{tabular}




\section{Appendix C \\ Listing of Sources for Information on Alternative Fueled Vehicles}

The EIA collects limited data pertaining to nonconventional transportation fuels and alternative fueled vehicles. Although these data are secondary in nature, they represent the most accurate available information assembled from: Federal, State, and local governments; the automobile manufacturing and transportation industries; fueling supply and distribution centers; and academia. The following is a compilation of sources used in this report.

\section{Federal Government}

General Services Administration

Environmental Protection Agency

Department of Transportation

National Renewable Energy Laboratory

Other Federal Agencies

\section{National Associations}

National Propane Gas Association

American Methanol Institute

\section{States}

\section{Alabama}

State and Private Vehicles:

Science Technology \& Energy Division, Alabama Department of Economic and Community Affairs

Alabama LP Gas Board

\section{Alaska}

State and Private Vehicles:

Alaska State Vehicles Office

\section{Arizona}

State and Private Vehicles:

Local Fleet:

Maricopa County Government

Equipment Management, City of Phoenix

\section{Arkansas}

State and Private Vehicles:

Arkansas Alternative Fuels Commission, Arkansas State Government Arkansas State Energy Office

AZ Industries, Inc.

Arkansas Department of Revenue, Motor Fuels Tax

\section{California}

State and Private Vehicles:

Transportation Technology and Fuels Office, California Energy Commission California Renewable Fuels Council

State Vehicles:

Alcohol-Fueled Fleet Test Program, California Air Resources Board

Alternative Fuel Vehicle Sales, General Motors Corp. 


\section{Colorado}

State and Private Vehicles:

State Fleet:

\section{Connecticut}

State and Private Vehicles:

State Fleet:

\section{Delaware}

State and Private Vehicles:

\section{District of Columbia}

State and Private Vehicles: Private Vehicles:

\section{Florida}

State and Private Vehicles:

\section{Georgia}

State and Private Vehicles:

Private Vehicles:

\section{Hawaii}

State and Private Vehicles:

\section{Idaho}

Federal Vehicles in the State: State and Private Vehicles:

State Fleet:

Private Vehicles:

\section{Illinois}

State and Private Vehicles:

State Vehicles:

\section{Indiana}

State and Private Vehicles:
Colorado Corn Growers Association

Colorado State Department of Natural Resources

Ethanol Management Company

Colorado Department of Revenue, Tax Analysts

State Fleet Service Office

Office of Policy and Management

Detroit Diesel-Atlantic Office

Connecticut State Fleet, Department of Administrative Services, Bureau of General and Technical Services

Delaware Department of Natural Resources and Environmental Control

D.C. Energy Office, Division of Environmental and Energy Policy American Methanol Institute

Florida State Energy Office Pilot Project, University of Florida

Florida Department of Revenue, Fuels Tax Registration

Georgia Department of Natural Resources

Georgia Office of Energy Resources

Georgia Corn Growers Association

Hawaii Natural Energy Institute, University of Hawaii Hawaii State Energy Office

Property Division, Idaho Bureau of Reclamation and Land Management Property Division, Idaho Bureau of Reclamation and Land Management Idaho State Department of Transportation Ethanol Marketing

Illinois Department of Energy and Natural Resources Illinois Corn Growers Association Alternative Fuel Vehicle Sales, General Motors Corp.

Indiana Corn Growers Association Indiana Commission of Agriculture Indiana State Energy Policy Office Indiana Department of Revenue, Special Tax 
Iowa

State and Private Vehicles:

State Vehicles:

\section{Kansas}

Private and State Vehicles:

\section{Kentucky}

State and Private Vehicles:

\section{Louisiana}

State and Private Vehicles:

Maine

State and Private Vehicles:

Maryland

State and Private Vehicles:

\section{Massachusetts}

State and Private Vehicles:

\section{Michigan}

State and Private Vehicles:

\section{Minnesota}

State and Private Vehicles:

\section{Mississippi}

State and Private Vehicles: lowa Corn Growers Association lowa State Vehicle Dispatcher, lowa State Department of General Services Alternative Fuel Vehicle Sales, General Motors Corp.

Kansas Corporation Commission Kansas Corn Growers Association

Natural Resources \& Environmental Protection Agency, Division of Energy Kentucky Corn Growers Association

Energy Division, Louisiana Department of Natural Resources Louisiana Soybean \& Grain Research and Promotion Board Louisiana Department of Transportation

Louisiana State Energy Office

Louisiana Department of Revenue, Excise Tax Division

Bureau of Air Quality Control, Maine Department of Environmental Protection Energy Conservation Division, Maine Department of Economic and Community Development

Maryland Grain Producers Association Maryland State Fleet

Massachusetts Division of Energy Resources Division of Air Quality Control, Massachusetts Dept. of Environmental Protection

Michigan Corn Growers Association Michigan State Motor Pool Office of Energy Programs, Michigan Public Service Commission Alternative Fuel Vehicle Sales, General Motors Corp.

Minnesota Corn Growers Association Minnesota Department of Agriculture Minnesota Division of Motor Vehicles, Agency Services Cashier Unit Minnesota Transit

Mississippi Corn Growers Association Mississippi State Energy Office Mississippi Division of Motor Vehicles 


\section{Missouri}

State and Private Vehicles:

State Vehicles:

\section{Montana}

State and Private Vehicles:

Private Vehicles:

\section{Nebraska}

State and Private Vehicles:

State Vehicles:

Nevada

State and Private Vehicles:

\section{New Hampshire}

State and Private Vehicles:

\section{New Jersey}

State and Private Vehicles:

\section{New Mexico}

State and Private Vehicles:

\section{New York}

State and Private Vehicles:

\section{North Carolina}

State and Private Vehicles:

Private Vehicles:

\section{North Dakota}

State and Private Vehicles:

State Vehicles:
National Corn Growers Association

Missouri Corn Growers Association

Missouri Motor Vehicles Bureau

Division of Energy, Department of Natural Resources

Montana Department of Natural Resources and Conservation

Montana Division of Motor Vehicles

Ethanol Producers and Consumers (EPAC)

Nebraska State Energy Office

Nebraska Corn Growers Association

Nebraska Gasohol Committee

State Transportation Services Bureau

Nevada Department of Transportation

Nevada Governor's Office of Community Service

New Hampshire Governor's Energy Office

New Hampshire Road Toll Administration

New Jersey State Energy Office

Energy Conservation and Management, Division, New Mexico Department of Energy, Minerals and Natural Resources

New Mexico Division of Motor Vehicles, Vehicle Registration

Southwest Technology Development Institute, New Mexico State University

New York State Energy Research and Development Authority

New York Corn Growers Association

New York Support Office, U.S. Department of Energy

North Carolina State Energy Office, North Carolina Department of Economic \& Community Development

Corn Growers Association of North Carolina

Lawrence McMerty, Energy Consultant

North Dakota State Energy Office, Office of Intergovernmental Assistance

North Dakota Corn Growers Association

Alternative Fuel Vehicle Sales, General Motors Corp. 
Ohio

State and Private Vehicles:

Ohio Corn Growers Association

Ohio Department of Agriculture

Ohio State Department of Transportation

\section{Oklahoma}

State and Private Vehicles:

Office of Public Affairs, Alternative Fuels Programs, State of Oklahoma

Private Vehicles:

Oklahoma Department of Revenue, Motor Fuels Section

Oklahoma State Red Cross

Oregon

State and Private Vehicles:

Oregon State Department of Energy

Northwest Ethanol Fuel Association

\section{Pennsylvania}

State and Private Vehicles:

Pennsylvania Master Corn Growers Association

Pennsylvania State Energy Office

\section{Rhode Island}

State and Private Vehicles:

Rhode Island Governor's Office of Housing, Energy and Intergovernmental Relations

\section{South Carolina}

State and Private Vehicles:

Energy, Agriculture, \& Natural Resources, Governor's Office Division of Energy South Carolina Corn Growers Association

\section{South Dakota}

State and Private Vehicles:

Governor's Office of Energy Policy

South Dakota Corn Growers Association

\section{Tennessee}

State and Private Vehicles:

Tennessee Corn Growers Association

Tennessee State Energy Office

Tennessee Department of Revenue, Highway Fuels Tax

Motor Vehicle Management, Tennessee State Energy Office

Texas

State and Private Vehicles:

Lone Star Corn Growers Association

Texas Governor's Energy Office

Texas Department of Revenue

Texas State University

\section{Utah}

State and Private Vehicles:

Utah Division of Energy

Utah Department of Agriculture

\section{Vermont}

State and Private Vehicles:

Vermont Department of Public Service

Vermont Motor Vehicles Division 


\section{Virginia}

State and Private Vehicles:

Division of Energy, Department of Mines, Minerals and Energy

State Vehicles:

Virginia Corn Growers Association

Washington

State and Energy Vehicles:

Washington State Energy Office

Washington Division of Motor Vehicles, Registration Information

\section{West Virginia}

State and Private Vehicles:

West Virginia Fuel and Energy Office

\section{Wisconsin}

State and Private Vehicles:

State Vehicles:

Wisconsin Corn Growers Association

Department of Aciministration, Wisconsin Department of Transportation Alternative Fuel Vehicle Sales, General Motors Corp.

Wyoming

State and Private Vehicles:

State Vehicles:

Energy Section, Division of Economic and Community Development Department of Transportation

Wyoming State Motor Pool

\section{Other Sources}

Electric Vehicles Association

The Electric Transportation Information Center

Natural Gas Utilities

CNG Refuelers

Gas Research Institute 


\section{Appendix D}

\section{References}

Major references used for the Alternatives to Traditional Transportation Fuels: An Overview are listed below. Other references and secondary sources are indicated in the footnotes for each chapter.

1. The Clean Air Act 42 U.S.C.\&\&7401-7671q as amended by the Clean Air Act Amendments of 1990, Public Law 101-549, November 15, 1990, 104 Stat. 2399.

2. Energy Policy Act of 1992, Public Law 102-486, October 24, 1992.

3. Executive Order 12844 of April 21, 1993, "Federal Use of Alternative Fueled Vehicles."

4. First Interim Report of the Federal Fleet Conversion Task Force, DOE/PO-0001, August 1993.

5. General Services Administration, "Existing and Future AFV Locations," September 1993.

6. National Research Council, Rethinking the Ozone Problem in Urban and Regional Air Pollution, Washington, DC, 1991.

7. U.S. Department of Energy, Office of Energy Demand Policy, Final Report of the Interagency Commission on Alternative Motor Fuels, DOE/EP0002P, September 1992.

8. U.S. Department of Energy, Office of Transportation Technologies, Federal Alternative Fuel Prograin Light Duty Vehicle Operations Second Annual Report to Congress for Fiscal Year 1992, DOE/EE-0004, July 1993.

9. U.S. Environmental Protection Agency, Office of Air Quality Planning and Standards, National Air Quality and Emissions Trends Report, 1991, 450-R-92001, October 1992.

10. U.S. Environmental Protection Agency, Office of Air Quality Planning and Standards, National Air Pollutant Emission Estimates, 1900-1991, EPA-454/R-92-013, October 1992.

11. U.S. Environmental Protection Agency, Office of Air Quality Planning and Standards, The Role of Ozone Precursors in Tropospheric Ozone Formation and Con-
trol-A Report to Congress, EPA-454/R-93-024, July 1993.

12. U.S. Environmental Protection Agency, Office of Air Quality Planning and Standards, Summary of NOx Control Technologies and their Availability and Extent of Application, EPA-450/3-92-004, February 1992.

13. U.S. Environmental Protection Agency, Office of Mobile Sources, Clean Air Act of 1990, January 1991.

14. U.S. Environmental Protection Agency, Office of Mobile Sources, Fuels and the 1990 Clean Air Act.

15. U.S. Environmental Protection Agency, Office of Mobile Sources, Motor Vehicles and the 1990 Clean Air Act.

References for Tables ES3 and 18 (compiled by the U.S. Environmental Protection Agency, Office of Mobile Sources)

16. Chang, Tai Y., Robert $H$. Hammerle, Steven $M$. Japar, and Irving T. Salmeen, "Alternative Transportation Fuels and Air Quality," Environmental Science and Technology, Vol. 25, No. 7 (1991), pp. 1190-1197.

17. DeLuchi, M.A., Emissions of Greenhouse Gases from the Use of Transportation Fuels and Electricity (Chicago, IL: Argonne National Laboratory), November 1993.

18. Sperling, Daniel, New Transportation Fuels: A Strategic Approach to Technological Change (Berkeley, CA: University of California Press), 1988.

19. U.S. Congress, Office of Technology Assessment, Replacing Gasoline: Alternative Fuels for Light-Duty Vehicles, OTA-E-364, September 1990.

20. U.S. Department of Energy, Assessment of Costs and Benefits of Flexible and Alternative Fuel Use in the U.S. Transportation Sector. Technical Report 7: Environmental, Health and Safety Concerns, October 1991. 


\section{Appendix E}

\section{Relationship of Fuel Chemistry to Engine Performance}

The conventional and alternative transportation fuels discussed in this publication are chemical compounds primarily consisting of the chemical elements hydrogen (denoted by symbol H) and carbon (represented by C). Some of the fuels contain only a single type of compound. Others, such as gasoline, are complex mixtures of compounds.

A compound containing only hydrogen and carbon is known as a hydrocarbon. The simplest and lightest forms of hydrocarbons are gaseous (e.g., methane, ethane, and propane). With increasing molecular weights, they are liquid (e.g., pentane, benzene); the heaviest ones are solids. Compounds containing a mix of hydrogen, carbon, oxygen (known by the symbol $\mathrm{O}$ ), sulfur (S), and other elements are typically known as organic compounds.

It is essential to understand the chemical structure of the fuel components to understand how the fuel will perform in the engine and the nature of the emission products that are produced. A number of attributes of the chemical compounds in the fuel are key to this understanding:

- The size of the molecules usually described in terms of the number of $\mathrm{C}$ atoms (e.g., a $\mathrm{C}_{6}$ hydrocarbon)

- The way in which the atoms are configured in the compound

- The ratio of hydrogen to carbon atoms

- The existence of $\mathrm{S}, \mathrm{O}$, and $\mathrm{N}$ within the compound and how those atoms are configured relative to the $\mathrm{H}$ and $\mathrm{C}$ atoms.

There are four principal types of hydrocarbon molecules: paraffins, olefins, aromatics, and naphthenes (or cycloparaffins). Carbon is quadrivalent, which means that it has four chemical bonds which combine with other atoms. Hydrogen has one chemical bond and so has a valency of one. The simplest hydrocarbon is methane, shown in Figure E1 as the first paraffin. Methane is a gas at normal temperature and pressure and is the primary constituent of natural gas. Shown below methane in Figure E1 are other paraffins: ethane, propane, and butane. All of the paraffins in this figure are gases, but with increasing boiling points. Butane boils at 31 degrees Fahrenheit. The next higher paraffin, pentane, containing five carbon atoms, is liquid. The key structural attribute that defines paraffins as a class of compounds is that all four carbon bonds are single links to other atoms, either hydrogen or another carbon. Paraffin hydrocarbons with only single bonds are described as being saturated.

In the column of Figure E1 labeled Olefins are hydrocarbons that contain at least one double bond. Compared to the paraffin, a second carbon-to-carbon bond has replaced a carbon-to-hydrogen bond.

In the sample compounds of Figure E1, $\mathrm{C}_{3}$ and $\mathrm{C}_{4}$ paraffins and olefins are shown. The names of the paraffin and olefin compounds are similar, e.g., propane and propylene (or propene). The important fuel chemistry difference between paraffins and olefins is the relative reactivity of the compounds. The paraffins are stable and relatively unreactive compounds. For example, it is very difficult to get methane to react with other compounds to form new ones. The presence of double bonds makes olefins much more reactive. This is a positive characteristic in the refinery or petrochemical plant, where olefins are valued for their ability to react and build desired compounds for fuels, plastics, and synthetic fibers. The olefins are also satisfactory engine fuels, but when they escape into the atmosphere from the fuel system or are not completely combusted in the engine system and escape to the atmosphere, the reactivity of olefins takes on a negative aspect. The olefin hydrocarbons in the atmosphere react readily to produce photochemical smog. The reactivity of olefins also poses a problem during storage, as they can oxidize to form gums, which can clog fuel injectors.

Oxygenates can be described readily within the context of hydrocarbon fuels. The alcohols are oxygenate compounds in which a hydrogen atom of the hydrocarbon has been replaced by a hydroxyl group (-OH). Methanol, as shown in Figure E1, is the $C_{1}$ alcohol in which an $\mathrm{OH}$ group produces a significant change, because compounds with the hydroxyl group exhibit 
Figure E1. Chemical Structure of Selected Alternative Fuel Hydrocarbons and Alcohols

Hydrogen Paraffins<smiles>CCCC</smiles><smiles>C=CC=C</smiles><smiles>CCCCC</smiles><smiles>C=CCCCCCCCCC</smiles>

Source: James G. Speight, The Chemistry and Technology of Petroleum (New York: Marcel Dekker, 1980).

strong molecular polarity. The affinity of the polar molecules causes methanol to be a liquid boiling at 148 degrees Fahrenheit, while methane is a gas boiling at -259 degrees Fahrenheit. How an oxygen molecule is structured within the hydrogen and carbon atoms of a molecule can be very significant. MTBE, an oxygenate commonly used in fuels, is an ether and has an oxygen atom that also lies between two carbon atoms as shown below.

MTBE has a boiling point of 131 degrees Fahrenheit, which is in the expected range of a $\mathrm{C}_{5}$ hydrocarbon.

$$
\text { MTEE: } \quad \begin{gathered}
\mathrm{CH}_{3}-\mathrm{H}_{3} \\
C-\mathrm{C}-\mathrm{CH}_{3} \\
\mathrm{CH}
\end{gathered}
$$

In Figure E2, some examples of the four classes of hydrocarbons are shown for compounds containing six carbon atoms. The two paraffins shown, hexane and isohexane, demonstrate that the paraffin carbon atoms can be lined up in linear fashion or can be branched off in various fashions (there are a number of possible branch combinations of the $C_{6}$ level). An olefin is shown; like the paraffins, olefins can also be branched molecules.

A naphthene is a saturated cyclic hydrocarbon. Usually, the basic rings have five or six carbon atoms, and multiple rings can be attached together. Multiple-ring naphthenes, with higher molecular weight and higher boiling point, are found in kerosene and diesel transportation fuels.

Aromatics is the term applied to a class of hydrocarbons based on a six-member ring in which the carbons are joined by alternating single and double 


\begin{tabular}{|c|c|c|}
\hline HC type & Example compound & \\
\hline n-paraffin & $\mathrm{CH}_{3}-\mathrm{CH}_{2}-\mathrm{CH}_{2}-\mathrm{CH}_{2}-\mathrm{CH}_{2}-\mathrm{CH}_{3}$ & hexane \\
\hline iso-paraffin & $\mathrm{CH}_{3}-\mathrm{CH}_{2}-\mathrm{CH}_{2}-\left.\right|_{\mathrm{CH}_{3}} ^{\mathrm{CH}}-\mathrm{CH}_{3}$ & isohexane \\
\hline $\begin{array}{l}\text { olefins } \\
\text { naphthenes } \\
\text { (cyclo-paraffins) }\end{array}$ & $\begin{array}{l}\mathrm{CH}_{3}-\mathrm{CH}_{2}-\mathrm{CH}_{2}-\mathrm{CH}_{2}-\mathrm{CH}=\mathrm{CH}_{2} \\
\left.\right|_{\mathrm{CH}_{2}} ^{\mathrm{CH}_{2}}-{ }_{\mathrm{CH}_{2}}^{-\mathrm{CH}_{2}}-\mathrm{CH}_{2}\end{array}$ & hexene \\
\hline aromatics & & benzene \\
\hline
\end{tabular}

Source: James G. Speight, The Chemistry and Technology of Petroleum (New York: Marcel Dekker, 1980).

bonds. The most basic of the aromatics is benzene, as shown in Figure E2. The ring structure of benzene is a symmetrical structure and is much less reactive than would be expected from the three unsaturated linkages (double bonds). Many of the aromatics found in gasoline are compounds in which one or more of the hydrogens in the single-ring structure has been replaced by a methyl group $\left(\mathrm{CH}_{3}\right)$ or longer alkyl chain $\left(-\mathrm{CH}_{2}-\mathrm{CH}_{2}\right.$ $\cdots \mathrm{CH}_{3}$ ).

A brief overview of how the chemistry and associated key properties of some of the various fuels and fuel compounds affect engine performance and engine emissions is shown in Table E1. Reactivity increases with molecular weight within a class. It is highest for the olefins. It is surprisingly low for benzene, even lower than $n$-hexane, the $C_{6}$ paraffin. Volatility, which is associated with evaporative losses, decreases as the molecular weight and number of carbon atoms increase. For paraffins, the straight-chain compound is more volatile than the isomers (branched-chain compounds) of the same molecular weight. The alcohols have high boiling points as pure compounds because of their polarity but when they are combined with other fuels where the alcohol is a minor component ( $<20$ percent), the polar affinity properties dissipate and they behave as much more volatile materials, as indicated by the blending RVPs (Table E1).

Since the mix of organic compounds and hydrocarbons in the fuel is a predictor of the compounds going across the catalytic converter, fuel/catalytic converter optimization is required in order to minimize ozone precursors. Some of the fuels contain increased quantities of oxygen and decreased quantities of sulfur and nitrogen. Oxygen is added to reduce $\mathrm{CO}$. Oxygenated gasoline is created through the addition of alcohol fuels and the ethers MTBE and ETBE to unleaded gasoline. Sulfur and nitrogen occur naturally in some gasoline feedstocks. Since sulfur corrodes engine parts, causes harmful emissions, and reduces catalytic converter effectiveness, refiners attempt to limit its content in gasoline. 
Table E1. Atmospherlc Reactlvity, Vapor Pressure, and Octane Numbers of Selected Hydrocarbons and Oxygenates

\begin{tabular}{|c|c|c|c|c|}
\hline Compound & $\begin{array}{l}\text { Atmospheric } \\
\text { Reactlvity' }\end{array}$ & $\begin{array}{l}\text { Blonding RVP } \\
(p a l)^{2}\end{array}$ & $\begin{array}{c}\text { Research } \\
\text { Octane Number }\end{array}$ & $\begin{array}{c}\text { Motor } \\
\text { Octane Number }\end{array}$ \\
\hline \multicolumn{5}{|l|}{ Parafiine } \\
\hline n-Butane $\ldots \ldots \ldots$ & 2.7 & 60 & 93.6 & 90.1 \\
\hline Isopentane ....... . & 3.6 & 21 & 92.3 & 90.3 \\
\hline n-Pentane $\ldots \ldots \ldots$ & 5.0 & 16 & 61.7 & 61.9 \\
\hline Isohexane ....... & 5.0 & 7 & 73.4 & 93.1 \\
\hline$n$-Hexane $\ldots \ldots \ldots$ & 5.6 & 5 & 24.8 & 26.0 \\
\hline \multicolumn{5}{|l|}{ Obefins } \\
\hline Butene-1 $\ldots \ldots \ldots$ & 30.0 & 65 & 97.4 & 81.7 \\
\hline Butene-2 $\ldots \ldots \ldots$ & 65.0 & 50 & 100 & 83.5 \\
\hline Pentene-1 $\ldots \ldots \ldots$ & 30.0 & 16 & 90.9 & 77.1 \\
\hline 2-Methyl 2-Butene .. & 85.0 & 15 & 97.3 & 84.7 \\
\hline 2-Methyl 1-Butene .. & 70.0 & 19 & -- & -- \\
\hline \multicolumn{5}{|l|}{ Aromatics } \\
\hline Benzene $\ldots . . . .$. & 1.3 & 3 & -- & 114.8 \\
\hline Toluene ......... & 6.4 & 0.5 & 120.1 & 103.5 \\
\hline M-xylene ........ & 23.0 & 0.3 & 117.5 & 115.0 \\
\hline \multicolumn{5}{|l|}{ Oxyornated } \\
\hline Methanol. & 1.0 & 60 & 107 & 92 \\
\hline Ethanol . . . . . . . & 3.4 & 18 & 108 & 92 \\
\hline MTBE $\ldots \ldots \ldots \ldots$ & 2.6 & 9 & 116 & 101 \\
\hline ETBE . . . . . . . . & 8.1 & 3.5 & 116 & 100 \\
\hline TAME $\ldots \ldots \ldots \ldots$ & 7.9 & 1.2 & 110 & 99 \\
\hline
\end{tabular}

'Gas phase reaction rate with the hydroxyl $(\mathrm{OH})$ radical.

${ }^{2}$ Values will vary with blendstocks.

Sources: G. Unzelman, "Refining Options and Gasoline Composition, 2000," NPRA: AM-92-05, New Orleans, LA, March 22-24, 1992; William J. Piel, "Oxygenate Flexibility for Future Fuels, "ARCO Chemical, presented at IRI Reformulated Gasoline Conference, October 1991; "Technical Data Book," prepared by Gulf Research and Development Company, 1962.

Octane is a positive property for spark-ignition fuels because the engine can be operated at higher compression ratios and hence higher efficiency. Octane number for the paraffins decreases as the number of carbon atoms increases, but at the same carbon number level, the octane number increases with the degrees of branching of the paraffin molecule. The octane of the $\mathrm{C}_{6}$ olefin (n-hexene) is higher at $70(\mathrm{R}+\mathrm{M}) / 2$ than the paraffin (26), but lower than the aromatic, benzene, at $106(\mathrm{R}+\mathrm{M}) / 2$.
From the data in Table E1, benzene would appear to be a very attractive motor fuel component-low reactivity, low vapor pressure, and high octane. Unfortunately, benzene has been found to be carcinogenic. The brief overview of the chemistry of fuels given in this appendix is meant to provide a basic understanding of the role of chemical structure in engine performance and emissions. The other attributes of fuels detailed in the chapters of this publication are also important for a full assessment of the performance and emissions attributes of fuels and fuel components. 


\section{Appendix F Fuel Cycle for Transportation Fuels}

The entire fuel cycle for transportation fuels can be represented pictoriall - The front end of the fuel cycle represents the resource recovery and processing; this affects the back end, where the fuel is consumed. Nodes represent points at which a distinct process occurs. Resource bases are drawn upon, the raw material is recovered, and fuel products are prepared and transported to refueling facilities. At the end of the fuel cycle, vehicles combust the fuel. At each point in the entire fuel cycle, emissions and waste byproducts are produced. 
Figure F1.

\section{ENTIRE FUEL CYCLE FOR TRANSPORTATION FUELS} Physical Flow Diagram - Mobile Source Emissions

REPLACEMENT FUEL

ELECTRICITY

NATURAL GAS (CNG, LNG) METHANOL MTBE

LIQUIFIED

PETROLEUM

GASES (LPG)
OIL \& GAS

\section{RESOURCE}

PROCESS

PRODUCT

VEHICLE

EMISSIONS

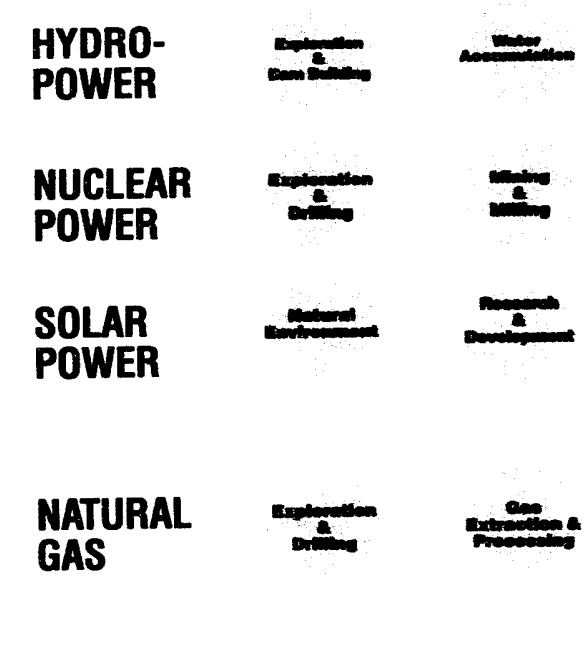

LIQUID FUELS

COAL

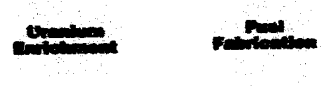

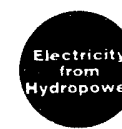

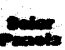
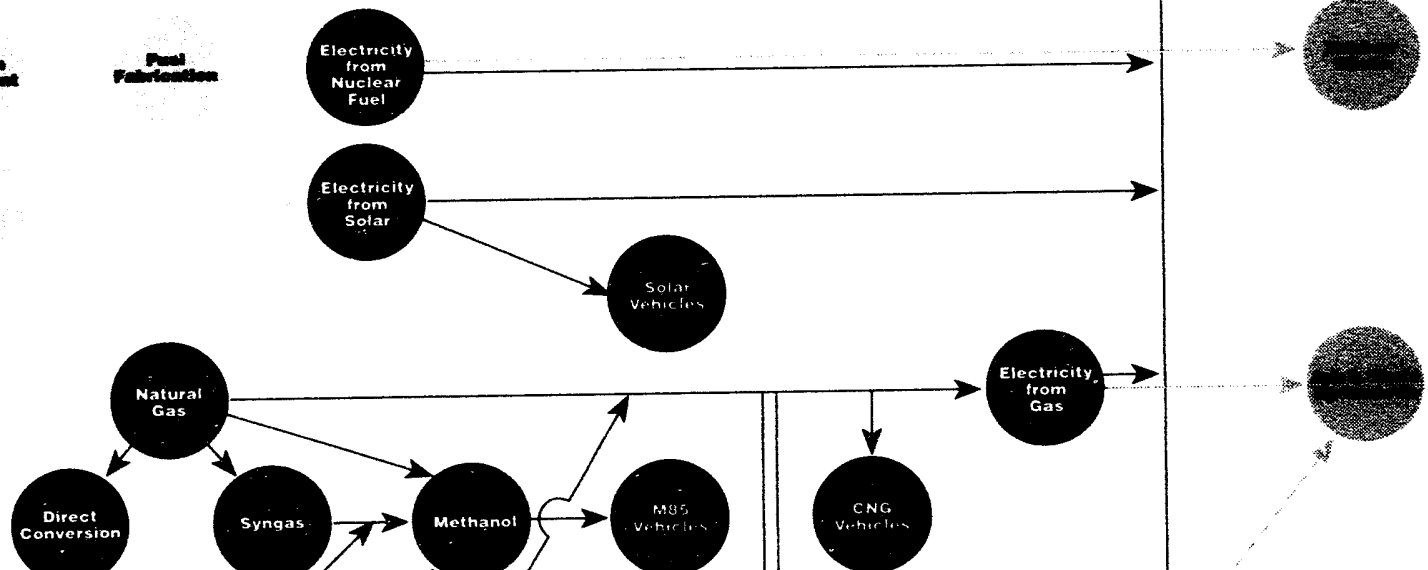

"Emissions occur during each process (represented by nodes) and each fuel movement

(lines). See NOTE." 


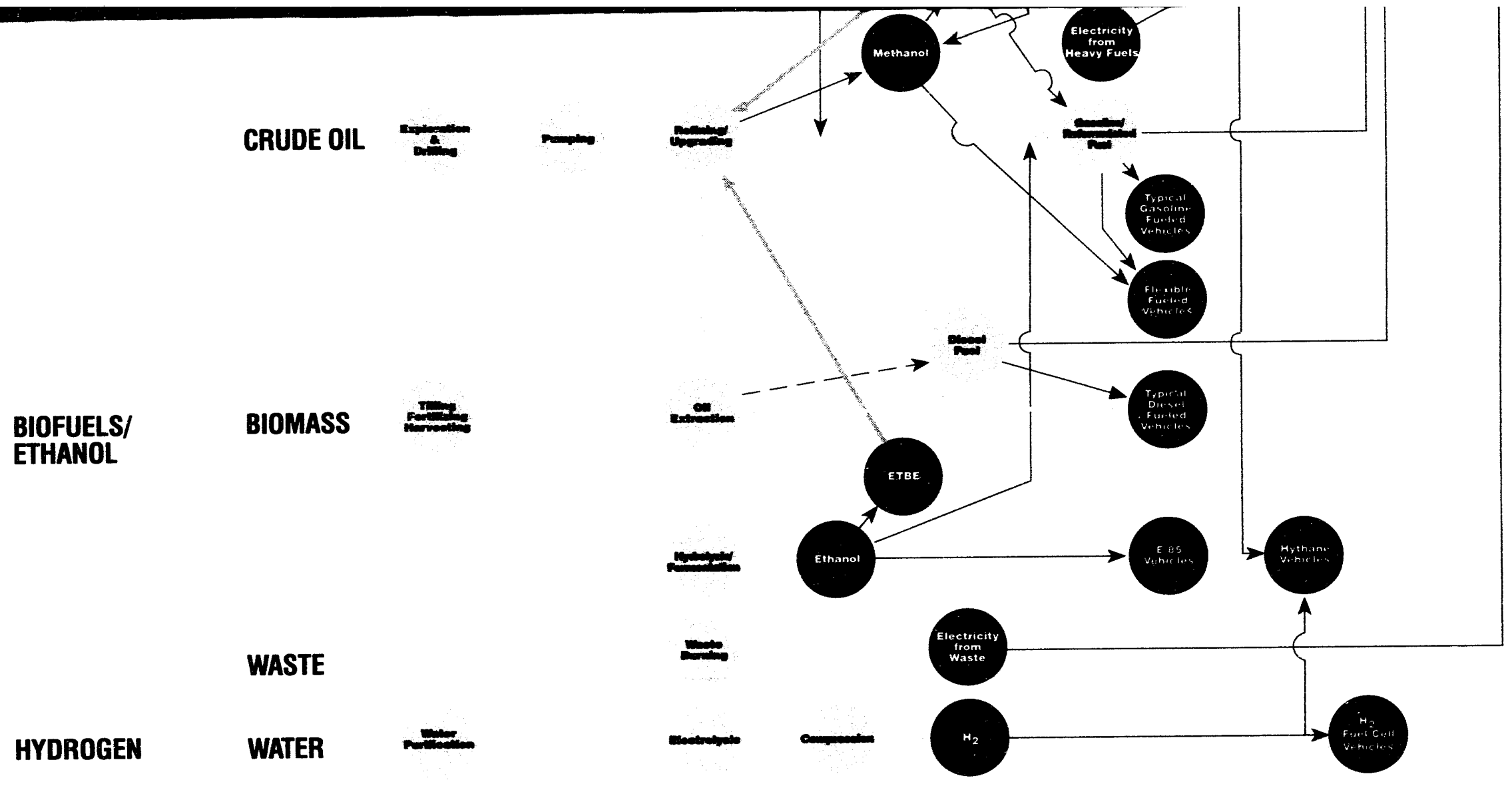

KEY:

\section{Stationary Energy Consumption \&
Emissions Due}

Mobille Source Energy Consumption

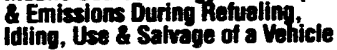

Distinet By-products with

Distinct By-products with

Energy Consumption E Emissions

Dua to Replacernent f

Energy Consumption \& Emissions Due To Transport

Physical Flow of Fuel into

Consummabie Form

Possible Plyzical Flow of Rape

Methyl Ester (RME)

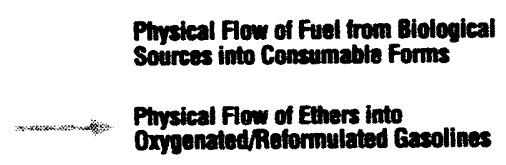

Physical Flow of Ehers into
Oxypenated/Reformulated Gasolines
- Plyxieal Flow of Replacement Fuels

Possible Phycical Flow of Replacement Fuets

Saste By-Products

NOTE:

Emissions and waste by-products occur with venting/fiaring during resource recovery, production processes, transport of products and refueling of vehicles, as woll as during the combustion phase of the entire fuel cycle. Emissions include all gases which collect in the atmosphere and act to prevent heat which omanates from the earth's surface from leaving the lower atmosphere: $\mathrm{H}_{2} \mathrm{O}, \mathrm{CO}_{2}, \mathrm{CO}, \mathrm{CH}_{4}, \mathrm{~N}_{2} \mathrm{O}, \mathrm{NO}$,, $\mathrm{SO}_{2}$, chlorofluorocarbons, volatile organic carbons, radioactive particles, particulate matter and aerosols. Waste by-products include water/brines from natural resources and processes, drilling muds, tallings, leachates, toxic and hazardous waste streams, heavy motals, ash, slag and objects which have reached the ond of their useable Ilves. 


\section{Glossary}

ACC Code: The General Services Administration Automotive Commodity Center (ACC) Code for vehicles contained in the Federal Standards.

Aerobic decomposition: The breakdown of a molecule into simpler molecules or atoms by microorganisms under favorable conditions of oxygenation.

After-market Conversion: A standard, conventionally fueled, factory-produced vehicle to which equipment has been added that enables the vehicle to operate on an alternative fuel.

Airshed: An area or region defined by settlement patterns or geology which result in discrete atmospheric conditions.

Alcohol $\left(\mathrm{CH}_{3}-\left(\mathrm{CH}_{2}\right)_{n}-\mathrm{OH}\right)$ : The family name of a group of organic chemical compounds composed of carbon, hydrogen, and oxygen. The series of molecules vary in chain length and are composed of a hydrocarbon, plus a hydroxyl group (for example, methanol, ethanol, and tertiary butyl alcohol).

Aldehydes: Aldehydes are formed as products of incomplete combustion in engines using gasoline, methanol, ethanol, propane, or natural gas as fuels. As a general rule of thumb, the presence of methanol or methyl ethers in the fuel will lead to formaldehyde as the primary aldehyde in the exhaust, while ethanol or ethyl ethers will lead to acetaldehyde as the primary aldehyde in the exhaust. In both cases, other aldehydes are present, but in much smaller quantities. Formaldehyde and acetaldehyde are toxic and possibly carcinogenic.

Alkylate: The product of an alkylation reaction. It usually refers to the high octane product from alkylation units. This alkylate is used in blending high octane gasoline.

Alkylation: A refining process for chemically combining isobutane with olefin hydrocarbons (for example, propylene, butylene) through the control of temperature and pressure in the presence of an acid catalyst, usually sulfuric acid or hydrofluoric acid. The product, alkylate, an isoparaffin, has high octane value and is blended with motor and aviation gasoline to improve the antiknock value of the fuel.

Alternative Fuel: As defined pursuant to the EPACT, methanol, denatured ethanol, and other alcohols, separately or in mixtures of 85 percent by volume or more (or other percentage not less than 70 as determined by DOE rule) with gasoline or other fuels, CNG, LNG, LPG, hydrogen, coal-derived liquid fuels, fuels other than alcohols derived from biological materials, electricity, or any other fuel determined to be substantially not petroleum and yielding substantial energy security benefits and substantial environmental benefits.

Alternative Fueled Vehicle: A vehicle either designed and manufactured by an original equipment manufacturer or a converted vehicle designed to operate in either dual-fuel, flexible-fuel, or dedicated modes on fuels other than gasoline or diesel. This does not include a conventional vehicle that is limited to operation on blended or reformulated gasoline fuels.

American Society for Testing and Materials: A nonprofit organization that provides a management system to develop published technical information. Standards, test methods, specifications, and procedures are recognized as definitive guidelines for motor fuel quality, as well as broad range of other products and procedures.

Anaerobic Decomposition: The breakdown of a molecule into simpler molecules or atoms by microorganisms that can survive in the partial or complete absence of oxygen.

Anode: A positive electrode (such as in a battery or radio tube).

Anthropogenic Emission: A type of emission produced as the result of human activities.

API Gravity: Scale expressing the gravity or density of liquid petroleum products as established by the American Petroleum Institute.

Aromatics: Aromatics are carbon compounds with the carbons strung together in rings. The basic ring has six carbon atoms and is shaped like a hexagon. Some heavier aromatics with two or more hexagonal rings with common sides (polycyclic aromatics) are also present in gasoline; some are formed during combustion. Aromatics are also unsaturated and have high energy content. Some aromatics are ozone-forming; some are toxic. Benzene and polycyclics are toxic; xylenes and some of the more complex aromatics are active ozone formers. Hydrocarbons characterized by unsaturated ring structures of carbon atoms. Commer- 
cial petroleum aromatics are benzene, toluene, and xylene.

Atmosphere: The envelope of air surrounding the Earth and bound to it by the Earth's gravitational attraction.

Atmospheric Crude Oil Distillation: The refining process of separating crude oil components at atmospheric pressure by heating to temperatures of about 600 to 750 degrees Fahrenheit (depending on the nature of the crude oil and desired products) and subsequent condensing of the fractions by cooling.

Balancing item: A measurement of the difference between the reported amount of natural gas produced and the amount consumed.

Barrel: A volumetric unit of measure for crude oil and petroleum products equivalent to $\mathbf{4 2}$ U.S. gallons.

Barrels Per Calendar Day: The maximum number of barrels of input that can be processed during a 24-hour period after making allowances for the following limitations:

- The capability of downstream facilities to absorb the output of crude oil processing facilities of a given refinery (no reduction is made when a planned distribution of intermediate streams through other than downstream facilities is part of a refinery's normal operation)

- The types and grades of inputs to be processed

- The types and grades of products expected to be manufactured

- The environmental constraints associated with refinery operations

- The reduction of capacity for scheduled downtime (such as routine inspection, mechanical problems, maintenance, repairs, and turnaround)

- The reduction of capacity for unscheduled downtime (such as mechanical problems, repairs, and slowdowns).

Barrels Per Stream Day: The number of barrels a unit can process running at full capacity under optimal crude-oil and product-slate conditions.

Battery Efficiency: The net direct current energy delivered on discharge, as a percentage of the total direct current energy required to restore the initial state-of-charge. The efficiency value must include energy losses resulting from self-discharge, cell equalization, thermal loss compensation, and all batteryspecific auxiliary equipment.

Benzene $\left(\mathrm{C}_{6} \mathrm{H}_{6}\right)$ : An aromatic hydrocarbon present in small proportion in some crude oils and made commer- cially from petroleum by the catalytic reforming of naphthenes in petroleum naphtha. Also made from coal in the manufacture of coke. Used as a solvent, in manufacturing detergents, synthetic fibers, and petrochemicals and as a component of high-octane gasoline. Benzene is a carcinogen.

Bi-Fueled Vehicle: A vehicle with two separate fuel systems designed to run on either an alternative fuel or conventional fuel using only one fuel at a time.

Biodiesel: Any liquid biofuel suitable as a diesel fuel substitute or diesel fuel additive or extender. A diesel substitute made from transesterification of oils of vegetables such as soybeans, rapeseed, or sunflowers (end product known as methyl ester) or from animal tallow (end product known as methyl tallowate). Biodiesel can also be made by transesterification of hydrocarbons produced by the Fisher-Tropsch process from agricultural byproducts such as rice hulls.

Biofuels: Wood, waste, and alcohol fuels.

Biogas: Methane gas produced from the anaerobic decomposition of organic material in a landfill, typically a low quality gas with numerous contaminants.

Biogenic: Produced by the actions of living organisms.

Biomass: Any renewable organic matter such as forestry and agricultural crops, crop-waste residues, wood, animal and municipal wastes, aquatic plants, fungal growth etc., used for the production of energy.

Biosphere: The portion of the Earth and its atmosphere that can support life. The part of the global carbon cycle that includes living organisms and life-derived organic matter.

Btu (British Thermal Unit): A standard unit for measuring the quantity of heat energy equal to the quantity of heat required to raise the temperature of 1 pound of water by 1 degree Fahrenheit.

Bulk Station: A facility used primarily for the storage and/or marketing of petroleum products which has a total bulk storage capacity of less than 50,000 barrels and receives its petroleum products by tank car or truck.

Bulk Terminal: A facility used primarily for the storage and/or marketing of petroleum products which has a total bulk storage capacity of 50,000 barrels or more and/or receives petroleum products by tanker, barge, or pipeline.

Butane $\left(\mathrm{C}_{4} \mathbf{H}_{10}\right)$ : A normally gaseous straight-chain or branch-chain hydrocarbon extracted from natural gas or refinery gas streams. In a production process, it would include both isobutane and normal butane. 
Butylene $\left(\mathrm{C}_{4} \mathrm{H}_{\mathbf{q}}\right)$ : An olefinic hydrocarbon recovered from refinery processes.

Calcination: A process in which a material is heated to a high temperature without fusing so that hydrates, carbonates, or other compounds are decomposed and the volatile material is expelled.

California Air Resources Board (CARB): A State regulatory agency charged with regulating the air quality in California. Air quality regulations established by the Board and often stricter than those set by the Federal Government.

Carbon Budget: The balance of the exchanges (incomes and losses) of carbon between the carbon reservoirs or between one specific loop (for example, atmosphere biosphere) of the carbon cycle.

Carbon Cycle: All reservoirs and fluxes of carbon; usually thought of as a series of the four main reservoirs of carbon interconnected by pathways of exchange. The four reservoirs, regions of the Earth in which carbon behaves in a systematic manner, are the atmosphere, terrestrial biosphere (usually includes freshwater systems), oceans, and sediments (includes fossil fuels). Each of these global reservoirs may be subdivided into smaller pools ranging in size from individual communities or ecosystems to the total of all living organisms (biota). Carbon exchanges from reservoir to reservoir by various chemical, physical, geological, and biological processes.

Carbon Dioxide $\left(\mathrm{CO}_{2}\right)$ : A colorless, odorless, nonpoisonous gas that is a normal part of the ambient air. Carbon dioxide is a product of fossil-fuel combustion. Although $\mathrm{CO}_{2}$ does not directly impair human health, it is a greenhouse gas that traps the earth's heat and contributes to the potential for global warming.

Carbon Monoxide (CO): A colorless, odorless gas slightly lighter than air. It is poisonous if inhaled, in that it combines with blood hemoglobin to prevent oxygen transfer. It is produced by the incomplete combustion of fossil fuels with a limited oxygen supply (as in automobiles). It is a major component of urban air pollution, which can be reduced by the blending of an oxygen-bearing compound such as alcohols and ethers into hydrocarbon fuels.

Carbon Sink: A pool (reservoir) that absorbs or takes up released carbon from another part of the carbon cycle.

Catalytic Cracking: The refining process of breaking down the larger, heavier, and more complex hydrocarbon molecules into simpler and lighter molecules. Catalytic cracking is accomplished by the use of a catalytic agent and is an effective process for increasing the yield of gasoline from crude oil.

Catalytic Hydrocracking: A refining process that uses hydrogen and catalysts with relatively low temperatures and high pressures for converting middle boiling or residual material to high-octane gasoline, reformer charge stock, jet fuel, and/or high grade fuel oil. The process uses one or more catalysts, depending upon product output, and can handle high-sulfur feedstocks without prior desulfurization.

Catalytic Hydrotreating: A refining process for treating petroleum fractions from atmospheric or vacuum distillation units (for example, naphthas, middle distillates, reformer feeds, residual fuel oil, and heavy gas oil) and other petroleum (for example, cat cracked naphtha, coker naphtha, or gas oil) in the presence of catalysts and substantial quantities of hydrogen. Hydrotreating includes desulfurization, removal of substances (for example, nitrogen compounds) that deactivate catalysts, conversion of olefins to paraffins to reduce gum formation in gasoline, and other processes to upgrade the quality of the fractions.

Catalytic Reforming: A refining process using controlled heat and pressure with catalysts to rearrange certain hydrocarbon molecules, thereby converting paraffinic and naphthenic type hydrocarbons (for example, low-octane gasoline boiling range fractions) into petrochemical feedstocks and higher octane stocks suitable for blending into finished gasoline.

Catalyst Petroleum Coke: In many catalytic operations (for example, catalytic cracking) carbon is deposited on the catalyst, thus deactivating the catalyst. The catalyst is reactivated by burning off the carbon, which is used as a fuel in the refining process. This carbon or coke is not recoverable in a concentrated form.

Charge Capacity: The input (feed) capacity of the refinery processing facilities.

Chlorofluorocarbons: A family of inert, nontoxic, and easily liquified chemicals used in refrigeration, air conditioning, packaging, and insulation, or as solvents or aerosol propellants. Because they are not destroyed in the lower atmosphere, they drift into the upper atmosphere where their chlorine components destroy ozone.

Clean Alternative Fuel: Any fuel (including methanol, ethanol, or other alcohols (including any mixture thereof containing 85 percent or more by volume of such alcohol with gasoline or other fuels), reformulated gasoline, diesel, natural gas, liquefied petroleum gas, and hydrogen) or power source (including electricity) used in a clean-fueled vehicle that complies with the 
standards and requirements of the Clean Air Act Amendments of 1990.

Clean-Fuel Vehicle: A vehicle for any model year in a class or category of vehicles that has been certified to meet the clean-fuel standards of the Clean Air Act Amendments of 1990 applicable for that model year.

Clinker: Powdered cement-produced by heating a properly proportioned mixture of finely ground raw materials containing calcium carbonate, silica, alumina, and iron oxide in a kiln to a temperature of about 2,700 degrees Fahrenheit at which partial fusion occurs.

Cloud Condensation Nuclei: Aerosol particles that provide a platform for the condensation of water vapor, resulting in clouds with higher droplet concentrations and increased albedo. It may be salt, particulate matter, pollen, or dust.

Coal: A black or brownish-black solid combustible substance formed by the partial decomposition of vegetable matter without access to air. The rank of coal, which includes anthracite, bituminous coal, subbituminous coal, and lignite, is based on fixed carbon, volatile matter, and heating value. Coal rank indicates the progressive alteration, or coalification, from lignite to anthracite. Lignite contains approximately 9 to 17 million Btu per ton. The heat contents of subbituminous and bituminous coal range from 16 to 24 million Btu per ton, and from 19 to 30 million Btu per ton, respectively. Anthracite contains approximately 22 to 28 million Btu per ton.

Compressed Natural Gas (CNG): Natural gas compressed to a volume and density that is practical as a portable fuel supply (even when compressed, natural gas is not a liquid).

Carbon Monoxide Control Area: The carbon monoxide control area is the larger of the Consolidated Metropoli$\tan$ Statistical Area or the Metropolitan Statistical Area in which a carbon monoxide nonattainment area is located.

Carbon Monoxide Control Period (Season): The portion of the year in which a carbon monoxide nonattainment area is prone to high ambient levels of carbon monoxide. This portion of the year is to be specified by the Environmental Protection Agency but is to be not less than 4 months in length.

Carbon Monoxide Nonattainment Area: Areas with carbon monoxide design values of 9.5 parts per million or more (generally based on data for 1988 and 1989).

Converted Vehicle: A vehicle originally designed to operate on gasoline that has been modified or altered to operate on an alternative fuel.
Conversion Hardware: Components/systems designed for retrofitting a vehicle to operate on an alternative fuel.

Criteria Pollutant: A pollutant determined to be hazardous to human health and regulated under the Environmental Protection Agency's National Ambient Air Quality Standards. The 1970 amendments to the Clean Air Act require Environmental Protection Agency to describe the health and welfare impacts of a pollutant as the criteria for inclusion in the regulatory regime.

Crude Oil (Including Lease Condensate). A mixture of hydrocarbons that exists in liquid phase in underground reservoirs and remains liquid at atmospheric pressure after passing through surface-separating facilities (includes lease condensate and liquid hydrocarbons produced from tar sands, gilsonite, and oil shale).

Crude Oil Qualities: The properties of crude oil, such as the sulfur content, API gravity, boiling range, and other properties that affect processing complexity and product characteristics.

Cultivar: A horticulturally or agriculturally derived variety of a plant.

Dedicated Vehicle: A vehicle designed to operate solely on one alternative fuel.

Deforestation: The removal of forest stands by cutting and burning to provide land for agricultural purposes, residential or industrial building sites, roads, or by harvesting the tress for building materials or fuel.

Degradable Organic Carbon: The portion of organic carbon from such solid waste as paper, food waste and yard waste which is susceptible to biochemical decomposition.

Delayed Coking: A process by which heavier (higher boiling) crude oil fractions can be thermally decomposed under conditions of elevated temperatures and pressure to produce a mixture of lighter oils and petroleum coke. The light oils can be processed further in other refinery units to meet product specifications. The coke can be used either as a fuel or in other applications such as the manufacturing of steel or aluminum.

Desulfurization: The removal of sulfur from molten metals, petroleum oil, or coal.

Diesel Fuel: A complex mixture of hydrocarbons with a boiling range between approximately 350 and 650 degrees Fahrenheit. Diesel fuel (also simply referred to simply as "diesel") is composed primarily of paraffins and naphthenic compounds that will auto-ignite from the heat of compression in a diesel engine. Diesel is 
used mainly by heavy-duty road vehicles, construction equipment, locomotives, marine and stationary engines.

Distillate Fuel Oil. A general classification for one of the petroleum fractions produced in conventional distiliation operations. It is used primarily for space heating, on- and off-highway diesel engine fuel (including railroad engine fuel and fuel for agricultural machinery), and electric power generation.

Dual-Fueled Vehicle: A vehicle designed to operate on a combination of alternative fuel, such as CNG or LPG, and conventional fuel, such as gasoline or diesel. These vehicles have two separate fuel systems which inject both fuels simultaneously into the engine combustion chamber.

E-10: (Gasohol) Ethanol/gasoline mixture containing 10 percent denatured ethanol and 90 percent gasoline, by volume.

E-85: A fuel containing a mixture of 85 percent ethanol and 15 percent gasoline.

B-93: A fuel containing a mixture of 95 percent ethanol and 15 percent gasoline.

Emission Credit Trading: A program administered by the Environmental Protection Agency under which low polluters are awarded credits which may be traded on a regulated market and purchased by polluters who are in noncompliance for emissions until compliance can be achieved.

Emiscion Standards: Standards for the levels of pollutants emitted from automobiles and trucks. Congress established the first standards in the Clean Air Act of 1963. Currently, standards are set for four vehicle classes-automobiles, light-duty trucks, heavy-duty gasoline trucks, and heavy-duty diesel trucks.

Energy Efficiency (Transportation): The inverse of energy intensiveness: the ratio of outputs from a process to the energy inputs (for example, miles traveled per gallon of fuel).

Energy Intensity (Transportation): The ratio of energy inputs to a process to the useful outputs from that process (for example, gallons of fuel per passenger-mile or Btu per ton-mile).

Environmental Protection Agency: A government agency, established in 1970. Its responsibilities include the regulation of fuels and fuel additives.

Ethyl Tertiary-Butyl Ether $\left(\left(\mathrm{CH}_{3}\right)_{3} \mathrm{COC}_{2} \mathrm{H}_{3}\right)$ : A colorless, flammable, oxygenated hydrocarbon blend stock formed by the catalytic etherification of isobutylene with ethanol.
Ethane ( $\left.\mathrm{C}_{2} \mathrm{H}_{\mathrm{W}}\right): \mathrm{A}$ normally gaseous straight-chain hydrocarbon extracted from natural gas and refinery gas streams. It is a colorless paraffinic gas that boils at a temperature of -127.48 degrees Fahrenheit.

Ethanol $\left(\mathrm{C}_{2} \mathrm{H}_{3} \mathrm{OH}\right)$ : Otherwise known as ethyl alcohol, alcohol, or grain-spirit. A clear, colorless, flammable oxygenated hydrocarbon with a boiling point of 78.5 degrees Celsius in the anhydrous state. However, it forms a binary azeotrope with water, with a boiling point of 78.15 degrees Celsius at a composition of 95.57 percent by weight ethanol. It is used in the United States as a gasoline octane enhancer and oxygenate (10 percent concentration). Ethanol can also be used in high concentration in vehicles optimized for its use.

Ether: A generic term applied to a group of organic chemical compounds composed of carbon, hydrogen, and oxygen, characterized by an oxygen atom attached to two carbon atoms (for example, methyl tertiary butyl ether).

Facultative Bacteria: Bacteria that grow equally well under aerobic and anaerobic conditions.

Fleet: A group of $\mathbf{2 0}$ or more light-duty vehicles which are capable of being centrally-fueled and are primarily used in a consolidated metropolitan statistical area with a population of 250,000 or more. These vehicles are owned, operated, leased, or controlled by a government entity, or by another person that controls 50 or more such vehicles. Exceptions include: rental vehicles, motor vehicles held for sale, test vehicles, law enforcement vehicles, emergency motor vehicles, military vehicles, nonroad vehicles (farm and construction equipment), and vehicles garaged at personal residences at night.

Flexible-Fueled Vehicle: A vehicle with the ability to operate on alternative fuels (such as M-85 or E-85), 100 percent petroleum-based fuels, or a mixture of alternative fuel and petroleum-based fuels.

Fluid Catalytic Cracking: The refining process of breaking down the larger, heavier, and more complex hydrocarbon molecules into simpler and lighter molecules. Catalytic cracking is accomplished by the use of a catalytic agent and is an effective process for increasing the yield of gasoline from crude oil. Catalytic cracking processes fresh feeds and recycled feeds.

Formaldehyde (HCHO): An aldehyde formed as a product of the incomplete combustion in engines using gasoline, methanol, ethanol, propane, or natural gas as fuels. As a general rule of thumb, the presence of methanol or methyl ethers in the fuel will lead to formaldehyde as the primary aldehyde in the exhaust. 
Focell Fuel: Any naturally occurring organic fuel formed in the Earth's crust, such as petroleum, coal, and natural gas.

Freah-Feed Input: Represents input of material (crude oil, unfinished oils, natural gas liquids, other hydrocarbons and oxygenates or finished products) to processing units at a refinery that is being processed (input) into a particular unit.

Fucls Solvent Deasphalting: A refining process for removing asphalt compounds from petroleum fractions, such as reduced crude oil. The recovered stream from this process is used to produce fuel products.

Fugitive Emissions: Unintended leaks of gas from the processing, transmission, and/or transportation of fossil fuels.

Fungible: A term used within the oil refining industry to denote products that are suitable for transmission by pipeline. Ethanol is not considered fungible in this sense, in that it would absorb any water accumulating in pockets in a pipeline.

Gas Oil: A liquid petroleum distillate having a viscosity intermediate between that of kerosene and lubricating oil. It is used to produce distillate fuel oils and gasoline.

Gasification: A method for exploiting poor-quality coal and thin-coal seams by burning the coal in place to produce combustible gas, which can be burned to generate power or processed into chemicals and fuels.

Gasohol: A mixture of 10 percent anhydrous ethanol and 90 percent gasoline by volume. There are other fuels that contain ethanol and gasoline, but these fuels are not referred to as gasohol. Future gasohol will contain 5.7 and 7.7 percent ethanol.

Global Warming: The theoretical escalation of global temperatures caused by the increase of greenhouse gas emissions in the lower atmosphere.

Government-Leased Vehicle: A vehicle obtained by an Executive agency by contract or other arrangement from a commercial source for a period of 60 continuous days or more.

Government-Owned, Contractor-Operated Vehicle: A vehicle that is owned by the Federal Government, but used by a commercial activity under a cost reimbursable contract to the Federal Government.

Government-Owned Vehicle: A vehicle owned by an Executive agency.

Greenhouse Effect: A popular term used to describe the roles of water vapor, carbon dioxide, and other trace gases in keeping the Earth's surface warmer than
It would be otherwise. These radiatively active gases are relatively transparent to incoming shortwave radiation, but are relatively opaque to outgoing longwave radiation. The latter radiation, which would otherwise escape to space, is trapped by these gases within the lower levels of the atmosphere. The subsequent reradiation of some of the energy back to the Earth maintains surface temperatures higher than they would be if the gases were absent.

Greenhouse Gases: Those gases, such as water vapor, carbon dioxide, tropospheric ozone, nitrous oxide, and methane, that are transparent to solar radiation but opaque to longwave radiation. Their action is similar to that of increased humidity in a greenhouse.

Grose Vehicle Weight Rating: The weight of the empty vehicle plus the maximum anticipated load weight.

Heavy-Duty Vehicles: Trucks and buses having a gross vehicle weight rating of 8,500 pounds or more.

Heavy-Gas Oll: A heavy fraction of crude oil separated by distillation, with an approximate boiling range from 651 to 1,000 degrees Fahrenheit.

Hydrocarbon: An organic chemical compound of hydrogen and carbon in either gaseous, liquid, or solid phase. The molecular structure of hydrocarbon compounds varies from the simple (e.g., methane, a constituent of natural gas) to the very heavy and very complex.

Hydrogen $\left(\mathrm{H}_{2}\right)$ : The lightest of all gases, the element (hydrogen) occurs chiefly in combination with oxygen in water. It also exists in acids, bases, alcohols, petroleum, and other hydrocarbons.

Hydroxyl Radical (OH): An important chemical scavenger of many trace gases in the atmosphere. Atmospheric concentrations of hydroxyl radical affect the atmospheric lifetime of trace gases, their abundances, and ultimately the effect they have on climate.

Inherently Low Emission Vehicle: Any vehicle that is certified to meet transitional low emission vehicle established by the California Air Resources Board and does not emit any evaporative emissions.

Intercity Bus: A standard size bus equipped with front doors only, high backed seats, luggage co npartments separate from the passenger compartment and usually with restroom facilities, for high-speed long distance service.

Isobutane $\left(\mathrm{C}_{4} \mathrm{H}_{10}\right)$ : A normally gaseous branch-chain hydrocarbon. It is a colorless paraffinic gas that boils at a temperature of 10.9 degrees Fahrenheit. It is extracted from natural gas or refinery gas streams. 
Icobutylene $\left(\mathrm{C}_{\mathbf{Q}} \mathrm{H}_{\mathbf{Q}}\right)$ : An olefinic hydrocarbon recovered from refinery processes or petrochemical processes.

Icomerization: A refining process that alters the fundamental arrangement of atoms in a molecule without adding or removing anything from the original material. This process is used to convert normal butane into isobutane $\left(C_{6}\right)$, an alkylation rocess feedstock, and normal pentane and hexane into isopentane $\left(C_{3}\right)$ and isohexane $\left(\mathrm{C}_{6}\right)$, high-octane gasoline components.

Kerosene: A petroleum distillate with a maximum distillation temperature of 401 degrees Fahrenheit at the 10-percent recovery point, a final boiling point of $\mathbf{5 7 2}$ degrees Fahrenheit, and a minimum flash point of 100 degrees Fahrenheit.

Leachate: A liquid that results from water collecting contaminants as it percolates through wastes.

Lead $\left(\mathrm{Pb}\left(\mathrm{C}_{2} \mathrm{H}_{3}\right)_{)}\right)$A poisonous metallic substance added to gasoline to increase its octane properties.

Light-Duty Vehicles: Automobiles and trucks having a gross vehicle weight rating of less than 8,500 pounds.

Light-Gas Oils: Liquid petroleum distillates heavier than naphtha, with an approximate boiling range from 401 to 650 degrees Fahrenheit.

Liquefied Natural Gas: Natural gas that has been refrigerated to temperatures at which it exists in a liquid state.

Liquefied Petroleum Gas: Propane, propylene, normal butane, butylene, isobutane, and isobutylene produced at refineries or natural gas processing plants (includes plants that fractionate raw natural gas plant liquids).

Load Factor: The potential capacity of a system relative to its actual performance (that is, the total passenger miles divided by total vehicle miles).

Low-Emission Vehicle (LEV): Any vehicle that is certified to meet the emission standards set by the California Air Resources Board.

Lubricant: A substance used to reduce friction between bearing surfaces or as a process material either incorporated into other materials used as processing aids in the manufacturing of other products or as carriers of other materials. Petroleum lubricants may be produced either from distillates or residues. Other substances may be added to impart or improve certain required properties. Does not include byproducts of lubricating oil from solvent extraction or tars derived from deasphalting. Lubricants includes all grades of lubricating oils from spindle oil to cylinder oil and those used in greases. Lubricants categories are paraffinic and naphthenic.
M-85: A fuel containing a mixture of 85 percent methanol and 15 percent gasoline.

M-100: 100 percent (neat) methanol.

Marketable Petroleum Coke: Those grades of coke produced in delayed or fluid cokers that may be recovered as relatively pure carbon, which may be sold as is or further purified by calcining.

Methane (CH): The simplest of the hydrocarbons and the chief constituent of natural gas. Methane, a gas at normal temperatures and pressures, boils at -263 degrees Fahrenheit. On board a vehicle, it is stored under high pressure at 2,500 to 3,600 pounds per square inch (psi). A gallon of natural gas at 2,000 psi contains about 20,000 Btu; at 3,600 psi, a gallon contains about 30,000 Btu. Gas coming from wells also can contain significant amounts of ethane, propane, butanes, and pentanes, and widely varying amounts of carbon dioxide and nitrogen. Pipeline-quality natural gas has had most, but not all natural gas liquids and other contaminants removed.

Methanogenic Bacteria: Bacteria which synthesize methane, requiring completely anaerobic conditions for growth.

Methanol $\left(\mathrm{CH}_{3} \mathrm{OH}\right)$ : A colorless poisonous liquid with essentially no odor and very little taste. The simplest alcohol, it boils at 64.7 degrees Celsius. It is miscible with water and most organic liquids (including gasoline) and is extremely flammable, burning with a nearly invisible blue flame. Methanol is produced commercially by the catalyzed reaction of hydrogen and carbon monoxide. It was formerly derived from the destructive distillation of wood, which caused it to be known as wood alcohol.

Methanotropic Bacteria: Bacteria that derive energy from the oxidation of methane.

Methyl Tertiary-Butyl Ether $\left(\left(\mathrm{CH}_{3}\right)_{3} \mathrm{COCH}_{3}\right)$ : A colorless, flammable, liquid oxygenated hydrocarbon that contains 18.15 percent oxygen and has a boiling point of 55.2 degrees Celsius. It is a fuel oxygenate produced by reacting methanol with isobutylene.

Middle Distillates: A general classification of refined petroleum products that includes distillate fuel oil and kerosene.

Midwest Region: This region includes the following States: Illinois, Indiana, lowa, Kansas, Michigan, Minnesota, Missouri, Nebraska, North Dakota, Ohio, South Dakota, and Wisconsin.

Miscellaneous Petroleum Products: Includes all finished products not classified elsewhere (for example, 
petrolatum, lube refining byproducts (aromatic extracts and tars), absorption oils, ram-jet fuel, petroleum rocket fuels, synthetic natural gas feedstocks, and specialty oils).

Model Year: In this publication, model year refers to the "sales" model year (October 1 through the next September 30).

Mole: A specified number of molecules $\left(6.023 \times 10^{23}\right)$.

Motor Bus: Rubber-tired, self-propelled, manuallysteered bus with fuel supply on board the vehicle. Motor bus types include intercity, school, and transit.

Motor Gasoline: A mixture of volatile hydrocarbons suitable for operation of an internal combustion engine whose major components are hydrocarbons with boiling points ranging from 78 to 217 degrees Celsius and whose source is distillation of petroleum and cracking, polymerization, and other chemical reactions by which the naturally occurring petroleum hydrocarbons are converted into those that have superior fuel properties.

Motor Gasoline Blending Components: Naphthas used for blending or compounding into finished motor gasoline (for example, straight-run gasoline, alkylate, reformate, benzene, toluene, and xylene). Excludes oxygenates (alcohols, ethers), butane, and pentanes plus. Oxygenates are reported as individual components and included in the total for other hydrocarbons, hydrogens, and oxygenates.

Motor Gasoline Blending of Oxygenates: Blending of gasoline and oxygenates under the Environmental Protection Agency's "Substantially Similar" Interpretive Rule (56 FR [February 11, 1991]).

Naphtha: A petroleum fraction with an approximate boiling range between 122 and 400 degrees Fahrenheit.

National Ambient Air Quality Standards (NAAQS): Ambient standards for air pollutants specifically regulated under the Clean air Act of 1990 that enable urban areas to achieve attainment. These pollutants include ozone, carbon monoxide, nitrogen dioxide, lead, particulate matter, and oxides of sulfur.

Natural Gas: A mixture of hydrocarbon compounds and small quantities of various nonhydrocarbons existing in the gaseous phase or in solution with crude oil in natural underground reservoirs at reservoir conditions.

Natural Gas Field Facility: A field facility designed to process natural gas produced from more than one lease for the purpose of recovering condensate from a stream of natural gas; however, some field facilities are designed to recover propane, normal butane, pentanes plus, and to control the quality of natural gas to be marketed.

Natural Gas Plant Liquids: Liquids recovered from natural gas in gas processing plants, and in some situations, from natural gas field facilities (includes natural gas liquids extracted by fractionators). These liquids are classified as ethane, propane, normal butane, isobutane, and pentanes plus.

Natural Gas Processing Plant: A facility designed (1) to achieve the recovery of natural gas liquids from the stream of natural gas which may or may not have been processed through lease separators and field facilities, and (2) to control the quality of the natural gas to be marketed. Includes cycling plants.

Natural Gasoline and Isopentane: A mixture of hydrocarbons, mostly pentanes and heavier, extracted from natural gas, that meets vapor pressure, endpoint, and other specifications for natural gasoline. This classification includes isopentane $\left(\mathrm{C}_{5} \mathrm{H}_{12}\right)$, a saturated branch-chain hydrocarbon obtained by fractionation of natural gasoline or isomerization of normal pentane.

Neat Alcohol Fuels: Straight alcohol (not blended with gasoline) that may be either in the form of ethanol or methanol. Ethanol, as a neat alcohol fuel, does not need to be at 200 proof; therefore, it is often used at 180 to 190 proof (90 to 95 percent). Most methanol fuels are not strictly "neat," since 5 to 10 percent gasoline is usually blended in to improve its operational efficiency.

Nitrogen Oxides: Air-polluting gases contained in automobile emissions, which are regulated by the Environmental Protection Agency. They comprise colorless nitrous oxide $\left(\mathrm{N}_{2} \mathrm{O}\right)$ (otherwise known as dinitrogen monoside, or as the anaesthetic "laughing gas"), colorless nitric oxide (NO), and the reddishbrown-colored nitrogen dioxide $\left(\mathrm{NO}_{2}\right)$. Nitric oxide is very unstable, and on exposure to air it is readily converted to nitrogen dioxide, which has an irritating odor and is very poisonous. It contributes to the brownish layer in the atmospheric pollution over some metropolitan areas. Other nitrogen oxides of less significance are nitrogen tetroxide $\left(\mathrm{N}_{2} \mathrm{O}_{4}\right)$ and nitrogen pentoxide $\left(\mathrm{N}_{2} \mathrm{O}_{5}\right)$. Nitrogen oxides are sometimes collectively referred to as " $\mathrm{NO}_{\mathrm{x}}$ " (or " $\mathrm{NO}_{\mathrm{x}}$ ") where ' $\mathrm{x}$ ' represents any proportion of oxygen to nitrogen.

Nonattainment Area: A region that exceeds minimum acceptable National Ambient Air Quality Standards (NAAQS) for one or more criteria pollutants, as determined by population density in accordance with the U.S. Census Bureau. Such regions (areas) are required to seek modifications to their State Implementation Plans, setting forth a reasonable timetable using means (approved by the Environmental Protection Agency) to 
achieve attainment of NAAQS by a certain date. Under the Clean Air Act, if a nonattainment area fails to attain NAAQS, the Environmental Protection Agency may superimpose a Federal Implementation Plan with stricter requirements or impose fines, construction bans, or cutoffs in Federal grant revenues until the area achieves applicable NAAQS.

Normal Butane $\left(\mathrm{C}_{4} \mathrm{H}_{10}\right)$ : A normally gaseous straightchain hydrocarbon. It is a colorless paraffinic gas that boils at a temperature of 31.1 degrees Fahrenheit. It is extracted from natural gas or refinery gas streams. grant revenues, etc., until the area achieves the applicable NAAQS.

Northeast Region: This region includes the following States: Connecticut, Maine, Massachusetts, New Hampshire, New Jersey, New York, Pennsylvania, Rhode Island, and Vermont.

Octane $\left(\mathrm{C}_{8} \mathrm{H}_{18}\right)$ : A flammable liquid hydrocarbon found in petroleum. One of the eighteen isomers of octane, 2,2,4-trimethylpentane is used as a standard in assessing the octane rating of fuels.

Octane Enhancer: Any substance (such as ethanol, methanol, benzene, toluene, xylene) that raises the octane rating when blended with gasoline.

Octane Number: A numerical measure of antiknock properties of motor fuel.

Olefins: Olefins are highly reactive unsaturated compounds (that is, the carbon atoms in the molecule able to accept additional atoms such as hydrogen or chlorine). Some are present in gasoline as a result of refinery manufacturing processes such as cracking. Some are created in the engine during combustion; most of these can be removed in the catalytic converter. They tend to be ozone formers and toxic. Because olefins tend to have moderate energy content, they are desirable fuel components from the point of view of energy density.

Olefin Content $\left(\mathrm{C}_{n} \mathrm{H}_{2 \mathrm{~N}}\right)$ : A class of unsaturated hydrocarbons containing one or more double bonds.

Original Equipment Manufacturers: Vehicle manufacturers that provide the original design and materials for assembly and manufacture of their product. They are directly responsible for manufacturing and modifying vehicles, making the vehicles commercially available, and providing a warranty for the finished product.

Oxygenated Fuel: Any fuel substance containing oxygen (includes oxygen-bearing compounds such as ethanol and methanol). Oxygenated fuel tends to give a more complete combustion of its carbon into carbon dioxide (rather than monoxide), thereby reducing air pollution from exhaust emissions.
Oxygenated Gasoline: Gasoline with an oxygen content of 1.8 percent or higher, by weight, that has been formulated for use in motor vehicles.

Ozone $\left(\mathrm{O}_{3}\right)$ : An oxygen molecule with 3 oxygen atoms that occurs as a blue, harmful, pungent-smelling gas at room temperature. The ozone layer, which is a concentration of ozone molecules located at 6 to 30 miles above sea level, is in a state of dynamic equilibrium. Ultraviolet radiation forms the ozone from oxygen, but can also reduce the ozone back to oxygen. The process absorbs most of the ultraviolet radiation from the sun, shielding life from the harmful effects of radiation. Ozone is normally present at ground level in low concentrations. In cities where a high level of air pollutants is present, the action of the sun's ultraviolet light can, through a complex series of reactions, produce a harmful concentration of ozone in the air. The resulting air pollution is known as photochemical smog. Certain air pollutants can drift up into the atmosphere and damage the balance between ozone production and destruction, resulting in a reduced concentration of ozone in the layer.

Ozone Precursor: A chemical compound (such as nitrogen oxides, methane, nonmethane hydrocarbons and hydroxyl radicals) that, in the presence of solar radiation, reacts with other chemical compounds to form ozone.

Particulate Matter: Particles formed by incomplete combustion of fuel, with diesel fuel generating about 1,000 times as much as gasoline per unit of fuel burned. The particles are primarily carbon, but other products of incomplete combustion (such as polycyclic aromatics) are absorbed on the particles. They are dirty and are suspected to be carcinogenic.

Pentanes Plus: A mixture of hydrocarbons (mostly pentanes and heavier) extracted from natural gas (includes isopentane, natural gasoline, and plant condensate).

Petroleum: A generic term applied to oil and oil products in all forms (such as crude oil, lease condensate, unfinished oil, refined petroleum products, natural gas plant liquids, and nonhydrocarbon compounds blended into finished petroleum products).

Petroleum Coke: A residue that is the final product of the condensation process in cracking. This product is reported as marketable coke or catalyst coke.

Petroleum Supply: The components of petroleum supply are field production, refinery production, imports, and net receipts, when calculated on a Petroleum Administration of Defense District basis.

Petrochemical Feedstock: Chemical feedstocks derived from petroleum principally for the manufacture of 
chemicals, synthetic rubber, and a variety of plastics. The categories reported are naphthas less than 401 degrees Fahrenheit and other oils equal to or greater than 401 degrees Fahrenheit endpoint.

Photolysis: The use of radiant energy to produce chemical changes.

Photosynthesis: The manufacture by plants of carbohydrates and oxygen from carbon dioxide and water in the presence of chlorophyll with sunlight as the energy source. Oxygen and water vapor are released in the process.

Pipeline (Petroleum): Pipelines used to transport crude oil and petroleum products respectively (including interstate, intrastate, and intracompany pipelines) within the 50 States and the District of Columbia.

Planetary Albedo: The fraction of incident solar radiation that is reflected by the Earth-atmosphere system and returned to space, mostly by backscatter from clouds in the atmosphere.

Production Capacity: The amount of product that can be produced from processing facilities.

Products Supplied: A measure which approximates the consumption of petroleum products, because it measures the disappearance of these products from primary sources (that is, refineries, natural gas processing plants, blending plants, pipelines, and bulk terminals). In general, it is computed for any given period as follows: field production plus refinery production, imports, and unaccounted for crude oil (plus net receipts when calculated on a Petroleum Administration of Defense District basis) minus stock change, crude oil losses, refinery inputs, and exports.

Propane $\left(\mathrm{C}_{3} \mathrm{H}_{8}\right)$ : A normally gaseous straight-chain hydrocarbon, it is a colorless paraffinic gas that boils at a temperature of -43.67 degrees Fahrenheit. It is extracted from natural gas or refinery gas streams.

Propylene $\left(\mathrm{C}_{3} \mathrm{H}_{6}\right)$ : An olefinic hydrocarbon recovered from refinery processes or petrochemical processes.

Radiatively Active Gases: Gases that absorb incoming solar radiation or outgoing infrared radiation, thus affecting the vertical temperature profile of the atmosphere.

Redox Potential: A measurement of the state of oxidation of a system.

Refinery: An installation that manufactures finished petroleum products from crude oil, unfinished oils, natural gas liquids, other hydrocarbons, and oxygenates.
Refinery Input: Total crude oil (domestic plus foreign) input to crude oil distillation units and other refinery processing units (such as cokers).

Refinery Yield: The percentage of finished product produced from input of crude oil and net input of unfinished oils. It is calculated by dividing the sum of crude oil and net unfinished input into the individual net production of finished products. Before calculating the yield for finished motor gasoline, the input of natural gas liquids, other hydrocarbons and oxygenates, and net input of motor gasoline blending components must be subtracted from the net production of finished motor gasoline. Before calculating the yield for finished aviation gasoline, input of aviation gasoline blending components must be subtracted from the net production of finished aviation gasoline.

Reflectivity: The ratio of the energy carried by a wave that is reflected from a surface to the energy of a wave incident to the surface.

Replacement Fuel: The portion of any motor fuel that is methanol, ethanol, or other alcohols, natural gas, liquefied petroleum gas, hydrogen, coal derived liquid fuels, electricity (including electricity from solar energy), ethers, or any other fuel the Secretary of Energy determines, by rule, is substantially not petroleum and would yield substantial energy security benefits and substantial environmental benefits.

Reformulated Gasoline (RFG): Gasoline whose composition has been changed (from that of gasolines sold in 1990 ) to 1) include oxygenates, 2) reduce the content of olefins and aromatics and volatile components, and 3 ) reduce the content of heavy hydrocarbons to meet performance specifications for ozone-forming tendency and for release of toxic substances (benzene, formaldehyde, acetaldehyde, 1,3-butadiene, and polycyclic organic matter) into the air from both evaporation and tailpipe emissions.

Reid Vapor Pressure (RVP): A measure of the vapor pressure in pounds per square inch of gasoline at 100 degrees Fahrenheit that indicates the volatility of a gasoline. Blending ethanol with gasoline tends to increase the Reid Vapor Pressure, while blending methyl tertiary butyl ether, and more particularly ethyl tertiary butyl ether, tends to reduce the Reid Vapor Pressure.

Renewable energy: Energy obtained from sources that are essentially inexhaustible (unlike fossil fuels). Renewable energy sources include conventional hydroelectric, wood, waste, geothermal, wind, photovoltaic, and solar thermal energy. 
Replacement Fuel: The portion of any motor fuel that is methanol, ethanol, or other alcohols, natural gas, liquefied petroleum gas, hydrogen, coal derived liquid fuels, electricity (including electricity from solar energy), ethers, or any other fuel the Secretary of Energy determines, by rule, is substantially not petroleum and would yield substantial energy security benefits and substantial environmental benefits.

Residual Fuel Oil: The heavier oils that remain after the distillate fuel oils and lighter hydrocarbons are distilled away in refinery operations and that conform to American Society Testing and Materials Specifications D396 and 975.

Scf: Standard cubic foot.

South Region: This region includes the following States: Alabama, Arkansas, Delaware, District of Columbia, Florida, Georgia, Kentucky, Louisiana, Maryland, Mississippi, North Carolina, Oklahoma, South Carolina, Tennessee, Texas, Virginia, and West Virginia.

Standard Item Number: The General Services Administration Automotive Commodity Center Code (Standard Item Number) for vehicles contained in the Federal Standards.

Stoichiometry: The calculation of the quantities of reactants and products involved in a chemical reaction.

Stratosphere: The region of the upper atmosphere extending from the tropopause (8 to 15 kilometers altitude) to about 50 kilometers. The thermal structure is determined by its radiation balance and is generally very stable with low humidity.

Sulfur: A nonmetallic element of lemon-yellow color, sometimes known as "brimstone."

Synthesis Gas: A gaseous fuel produced from natural gas, composed primarily of carbon monoxide and hydrogen.

Syngas: A gaseous fuel produced from heating biomass composed primarily of carbon monoxide and hydrogen.

Tank Farm: An installation used by gathering-andtrunk pipeline companies, crude oil producers, and terminal operators (except refineries) to store crude oil.

Tax Incentives: In general, a means of employing the tax code to stimulate investment in or development of a socially desirable economic objective without the direct expenditure from the budget of a given unit of government. Such incentives can take the form of tax exemptions or credits.
Tertiary Amyl Methyl Ether $\left(\left(\mathrm{CH}_{3}\right)_{2}\left(\mathrm{C}_{2} \mathrm{H}_{3}\right) \mathrm{COCH}_{3}\right)$ : An oxygenate blend stock formed by the catalytic etherification of isoamylene with methanol.

Thermal Cracking: A refining process in which heat and pressure are used to break down, rearrange, or combine hydrocarbon molecules (includes gas oil, visbreaking, fluid coking, delayed coking, and other thermal cracking processes).

Trace gas: A minor constituent of the atmosphere.

Transesterification: A process by which an alcohol is combined with the degummed and processed oils from the seeds of soybeans, rapeseed, sunflowers, or other vegetables (or animal tallow) to make a biodiesel fuel. Glycerin is a byproduct. Fuel from soybeans is known as methyl ester; fuel from animal tallow is known as methyl tallowate. One bushel of soybeans yields 1.6 gallons of methyl ester.

Transit Bus: A bus designed for frequent stop service with front and center doors, normally with a rearmounted diesel engine, low-back seating, and without luggage storage compartments or restroom facilities. Includes motor bus and trolley coach.

Transitional Low Emission Vehicle: Any vehicle that is certified to meet the least stringent emission standards established by the California Air Resources Board. These standara's have the highest standards for nonmethane organic gas, carbon monoxide and nitrogen oxide emissions.

Trolley Coach: Rubber-tired electric transit vehicle, manually-steered, propelled by a motor drawing current, normally through overhead wires, from a central power source not on board the vehicle.

Troposphere: The inner layer of the atmosphere below about 15 kilometers, within which there is normally a steady decrease of temperature with increasing altitude. Its thermal structure is caused primarily by the heating of the Earth's surface by solar radiation, followed by heat transfer by turbulent mixing and convection. Nearly all clouds are formed and weather conditions manifest within this region.

Ultra-low Emission Vehicle: A vehicle that meets stringent emission standards.

U.S. Gallon: A volume measure equivalent to 4 quarts or 3.785 liters (231 cubic inches).

Vacuum Distillation: Distillation that occurs under reduced pressure (less than atmospheric) and that lowers the boiling temperature of the liquid being 
distilled. This technique, with its relatively low temperatures, prevents cracking or decomposition of the charge stock.

Vented Natural Gas: Gas released into the air on the base site or at processing plants.

Volatile Organic Compounds (VOCs): Carbon-based emissions (released through evaporation and/or combustion) combined with nitrogen oxides in the presence of sunlight to form ozone. Air pollution gases that are contained in automobile emissions and that are regulated by the Environmental Protection Agency.

Volatility: The tendency of a solid or liquid to pass into the vapor state at a given temperature. The volatility of automotive fuels is determined by measuring the Reid Vapor Pressure.

West Region: This region includes the following States: Alaska, Arizona, California, Colorado, Hawaii, Idaho,
Montana, Nevada, New Mexico, Oregon, Utah, Washington, and Wyoming.

Wetland: An area regularly saturated by surface or groundwater and subsequently characterized by a prevalence of vegetation adapted for life in saturatedsoil conditions.

Wood energy: Wood and wood products used as fuel (includes roundwood (cordwood), limbwood, wood chips, bark, sawdust, forest residues, charcoal, pulp waste, and spent pulping liquor).

Zero Emission Vehicle (ZEV): Any vehicle that is certified to meet the most stringent emission standards established by the California Air Resources Board. These standards require zero regulated emissions of nonmethane organic gases, carbon monoxide, and nitrogen oxide. 

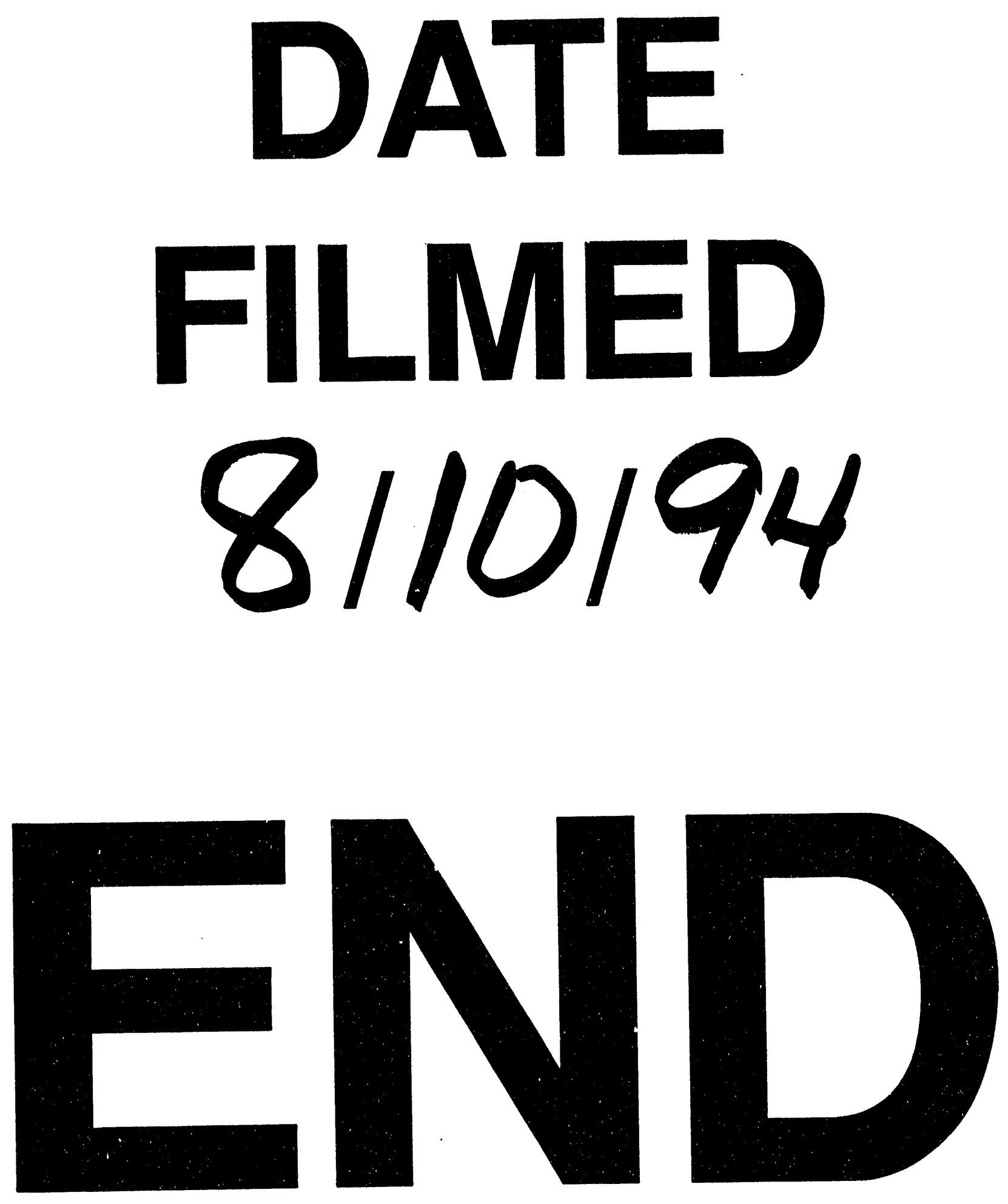
